Leonardo Alonso

\title{
Crimes contra o Mercado de Capitais
}

Dissertação de Mestrado apresentada ao Departamento de Direito Penal, Medicina Forense e Criminologia da Faculdade de Direito da Universidade de São Paulo, como requisito parcial para a obtenção do título de Mestre.

Orientador: Professor Associado Renato de Mello Jorge Silveira

Faculdade de Direito da Universidade de São Paulo

São Paulo

2009 
Para Viviane, minha

grande companheira na vida

Para Marcelo, pela descoberta do amor incondicional 


\section{AGRADECIMENTOS}

Muitas foram as pessoas que, a seu modo, contribuíram para a realização deste trabalho:

Agradeço em primeiro lugar ao Prof. Renato de Mello Jorge Silveira, por ter me acolhido como orientando, por compartilhar comigo seus conhecimentos no âmbito das ciências penais e pela orientação dedicada, sem a qual a realização deste trabalho não seria possível.

Aos amigos de escritório, Prof. Miguel Reale Júnior, Eduardo Reale Ferrari, Luiz Guilherme Moreira Porto, Helena Regina Lobo da Costa e Osvaldo Gianotti Antoneli, por incentivarem a vida acadêmica, pelas contribuições decorrentes da leitura da presente dissertação e, acima de tudo, por me possibilitarem vivenciar, na prática da advocacia, a aplicação do direito penal no âmbito do Mercado de Capitais.

A Cecília Andreotti Atienza Alonso, pelo amor dedicado e pelo incansável estímulo ao estudo.

Aos meus pais José Carlos e Elizabeth, e meu irmão Daniel, por me transmitirem valores sólidos, e por todo o apoio nos momentos mais importantes de minha vida.

Agradeço também às Professoras Mariângela Gama de Magalhães Gomes e Ana Elisa Liberatore Bechara, pelos proveitosos comentários proferidos quando do exame de qualificação.

Aos amigos Eduardo Schuch e Renato Luis Bueloni Ferreira, pelo incentivo e contribuição quanto aos aspectos relacionados ao direito societário e direito do Mercado de Capitais.

Deixo também meu muito obrigado a Victor Falcone, Giovanni Peduto, Fabiano Carvalho, Ivan Mocivuna e Rodrigo Giarola, pela colaboração com a presente dissertação e, acima de tudo, pela amizade sincera.

Aos demais colegas advogados da Reale e Moreira Porto Advogados Associados (Filipe Magliarelli, Tatiana Stoco e Rodrigo Teixeira), bem como a todos os estagiários e funcionários, pela dedicação e suporte demonstrados.

Ficam, por fim, meus saudosos agradecimentos a José Alonso Filho, Dolores Alba Alonso, Natália Neubarth Terrav, Francisco Xavier Atienza Júnior e Domingas Andreotti Atienza, com quem pude compartilhar e aprender as lições da vida.

A todos, meu muito obrigado. 
“Conhece-te a ti mesmo" é toda a ciência. Apenas no final do conhecimento de todas as coisas o homem terá conhecido a si mesmo. Pois as coisas são apenas as fronteiras do homem.

Friedrich Nietzsche 


\section{SUMÁRIO}

INTRODUÇÃO

\section{A EXPANSÃO DO DIREITO PENAL E A TUTELA DO MERCADO}

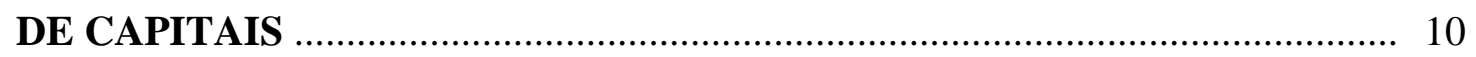

1.1. Globalização, expansão do mercado de capitais e incremento do direito penal econômico .................................................................... 14

1.2. A questão comunitária e a segurança dos mercados .................................... 20

2. O MERCADO DE CAPITAIS E SUAS PARTICULARIDADES .................... 26

2.1. Conceito e princípios norteadores ................................................................ 26

2.2. A tradicional regulação dos mercados no Brasil .......................................... 32

2.2.1. Principais diplomas legais: Lei do Mercado de Capitais

e Lei das Sociedades Anônimas ................................................................ 36

2.2.2. Do controle administrativo .............................................................. 42

2.2.2.1. A Comissão de Valores Mobiliários: CVM ................................ 43

2.2.2.2. Processo administrativo ........................................................ 47

2.3. A dúvida da necessidade de controle penal .............................................. 52

\section{O PROCESSO DE CRIMINALIZAÇÃO DA TUTELA PENAL}

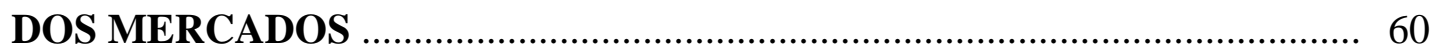

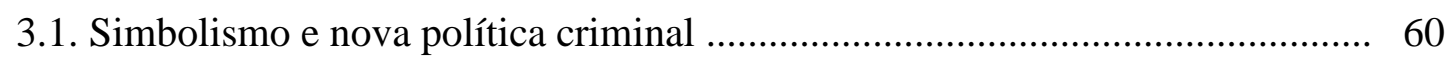

3.2. Internacionalização do Direito Penal ............................................................ 63

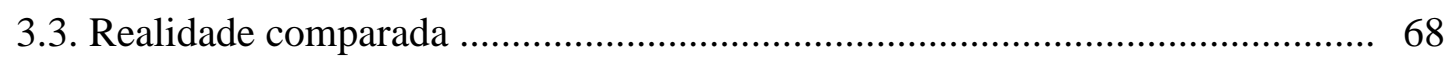

3.3.1. Estados Unidos da América .............................................................. 68

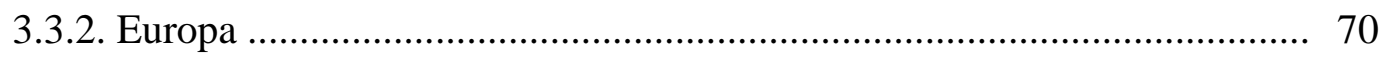

4. A TUTELA PENAL DOS MERCADOS NO BRASIL .................................. 76

4.1. Bem jurídico protegido ou simples normatização? ......................................... 76

4.1.1. Evolução histórica e crise do conceito de bem jurídico:

breves apontamentos ...................................................................... 76

4.1.2. O bem jurídico nos crimes contra o mercado de capitais ....................... 94 
4.1.2.1. Tutela patrimonial dos investidores

4.1.2.2. Tutela da igualdade entre os investidores ................................ 99

4.1.2.3. Tutela da confiança dos investidores ....................................... 104

4.1.2.4. Tutela dos interesses da sociedade emissora dos valores mobiliários ........................................................... 106

4.1.2.5. Tutela do correto funcionamento do mercado de valores mobiliários ............................................................. 108

4.1.2.6. Conclusões quanto ao bem jurídico protegido ........................... 112

4.2. A construção típica .................................................................................... 118

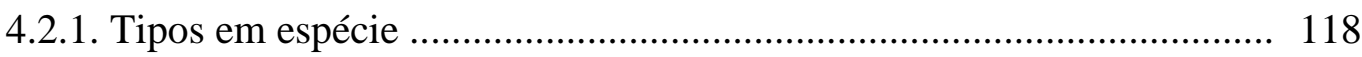

4.2.1.1. Manipulação de mercado .................................................... 119

4.2.1.2. Uso indevido de informação privilegiada:

Insider Trading ................................................................ 125

4.2.2. Tipos abertos e crimes de perigo …................................................... 134

4.3. Do aperfeiçoamento da tutela penal .............................................................. 143

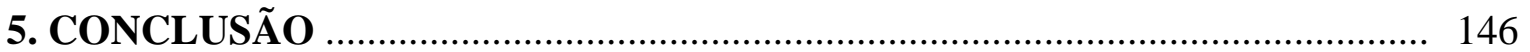

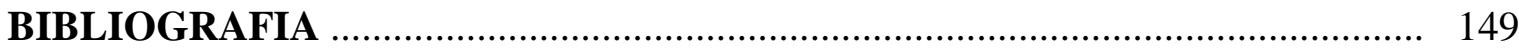

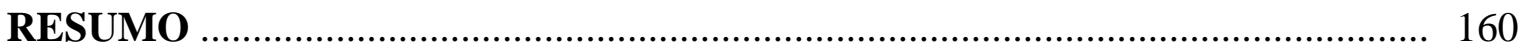

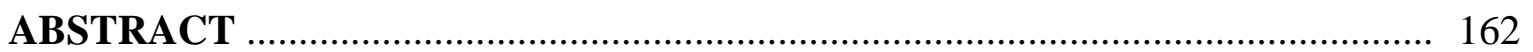




\section{INTRODUÇÃO}

A necessidade de efetiva proteção dos Mercados de Capitais é, atualmente, irrefutável. Tanto o desenvolvimento tecnológico como a livre circulação de capital em uma economia 'globalizada'; expõem os mercados, e os investidores que neles mobilizam suas poupanças, a uma nova classe de riscos, mormente em face da possibilidade de aferição, em curto prazo, de ganhos de grande monta resultantes de atividades especulativas que nem sempre se limitam ao jogo de riscos inerente ao Mercado de Capitais.

É certo, também, que tais mercados são dotados de ineficiências intrínsecas que propiciam a prática de ilícitos, como a manipulação de mercado e o uso indevido de informação privilegiada.

Ocorre que nem sempre o controle administrativo se mostra suficientemente eficiente à prevenção e repressão de tais práticas ofensivas aos Mercados de Capitais, fato que, via de regra, implica na utilização do direito penal para se alcançar referidos fins. Contudo, tal criminalização se mostra, no mais das vezes, dotada de um caráter simbólico; voltado à satisfação de anseios da opinião pública, refletindo um abandono dos preceitos garantistas do direito penal e resultando em mera normatização.

Dessa forma, cabe se fazer uma reflexão crítica acerca do bem jurídico tutelado nos crimes contra o Mercado de Capitais, ante a imprescindibilidade de um referente material dos tipos penais, sendo este o ponto central da presente dissertação.

Faz-se necessário, assim, buscar os critérios indispensáveis para a legitimação da intervenção penal no Mercado de Capitais.

Esses os temas abrangidos na presente dissertação, que serão percorridos ao longo de cinco capítulos.

O primeiro capítulo destina-se ao estudo da expansão do direito penal frente aos novos riscos decorrentes da sociedade pós-moderna. Serão analisadas as teorias 
favoráveis e contrárias a tal expansão do direito penal que, via de regra, resulta em propostas de flexibilização do direito penal clássico em prol do combate a novos tipos de criminalidade, notadamente, aquelas relacionadas às atividades econômicas e empresariais.

Outro aspecto a ser abordado neste primeiro capítulo diz respeito à contextualização do fenômeno da "globalização"; em especial no tocante à expansão do Mercado de Capitais, e seus efeitos com relação ao direito penal, que resultaram no incremento do chamado direito penal econômico.

No segundo capítulo serão estudados os principais aspectos do Mercado de Capitais, seu conceito e princípios informadores. Em um segundo momento serão analisados os principais aspectos da regulação do Mercado de Capitais no Brasil; partindose de uma contextualização histórica e passando pela observação dos principais diplomas legais que regulam a matéria. Serão observados, ainda, os principais aspectos do controle administrativo do Mercado de Capitais, apartado em que se procurará delimitar o bem juridicamente tutelado pelas normas administrativas e relevante estudo referente ao órgão regulador do mercado brasileiro, a Comissão de Valores Mobiliários, no desempenho de suas funções normativas, executivas e judicantes.

O capítulo se encerra com uma reflexão acerca da necessidade de tutela penal do Mercado de Capitais, ou se a matéria estaria suficientemente regulada por meio de normas de natureza civil e administrativa. Nesse contexto, será feita uma exposição das manifestações contrárias à criminalização do uso indevido de informação privilegiada; sendo certo que alguns autores defendem, até mesmo, uma auto-regulamentação do Mercado de Capitais. Serão também colacionadas as principais manifestações da doutrina estrangeira, favoráveis e contrárias às criminalização de condutas ofensivas ao Mercado de Capitais. Por fim, pretende-se, no capítulo em questão, apontar critérios científicos capazes de nortear a verificação da necessidade de tutela penal para o Mercado de Capitais.

No terceiro capítulo serão tratados os principais aspectos que levam à criminalização do Mercado de Capitais, dentre os quais se destacam a utilização simbólica do direito penal apenas para satisfazer anseios e clamores sociais, e a sua internacionalização, não somente quanto a uma tendência de harmonização das legislações em todo o mundo; como também a influência de determinados sistemas regulatórios, como 
o norte-americano, na tipificação de condutas lesivas ao Mercado de Capitais. Por fim, será feita uma breve exposição quanto ao atual regramento da matéria no direito comparado, notadamente, nos sistemas dos Estados Unidos da América e Europa Continental.

O quarto capítulo tratará da análise específica quanto à tutela penal do Mercado de Capitais no Brasil.

Em um primeiro apartado se buscará a identificação do bem juridicamente tutelado nos crimes contra o Mercado de Capitais. Consoante afirmado anteriormente, trata-se da principal investigação proposta na presente dissertação. Para tanto, serão delineadas as principais teorias acerca do bem jurídico; bem como se tratará da questão dos bens jurídicos supra-individuais e sua proteção por meio de crimes de perigo abstrato. Especificamente no tocante ao bem jurídico nos crimes contra o Mercado de Capitais, serão expostas as principais teorias adotadas na doutrina estrangeira e, ao final do apartado, serão indicadas as conclusões quanto ao tema.

Serão ainda analisados com maior detalhamento dois dos três tipos penais da Lei 6.385/76, notadamente os crimes de manipulação de mercado e uso indevido de informação privilegiada; tendo em vista serem aqueles que tratam das condutas relativas às operações propriamente ditas. Nesse contexto, ao se estudar os tipos penais que tutelam o Mercado de Capitais, se tratará de fazê-lo sob duas linhas de argumentação: i) a impossibilidade da criação de tipos penais excessivamente abertos; e ii) a busca de critérios para a utilização de crimes de perigo abstrato na proteção dos delitos coletivos.

O capítulo se encerra com a formulação, ainda que embrionária, de uma proposta de aperfeiçoamento da tutela penal do Mercado de Capitais no Brasil, a qual levará em conta necessariamente as conclusões a respeito do bem jurídico tutelado, bem como as preocupações acima referidas quanto aos cuidados relativos à construção típica.

O último capítulo trará as conclusões do trabalho. 


\section{A EXPANSÃo DO DIREITO PENAL E A TUTELA DO MERCADO DE CAPITAIS}

A evolução histórica de nossa sociedade, especialmente após o período entendido como pós-modernidade, trouxe uma série de novos riscos ${ }^{1}$, decorrentes do aperfeiçoamento das relações econômicas e do incremento tecnológico desenfreado.

Tais riscos, por certo, representaram a criação de um cem número de conflitos e, por conseqüência, colocaram em xeque o direito penal clássico, obrigando um novel posicionamento dogmático-penal frente a essas atuais questões ${ }^{2}$.

Como exemplo desses novos riscos, a questão ambiental, as relações de consumo, o comércio eletrônico, e, sem sombra de dúvidas, uma nova economia globalizada, na qual está inserido, com um papel de extrema relevância, o Mercado de Capitais.

\footnotetext{
${ }^{1}$ Termo cunhado pelo sociólogo alemão Ulrich Beck em 1.986, a chamada sociedade de risco objetiva definir uma sociedade pós-industrial, marcada pela quebra de diversos paradigmas (papéis dos sexos, unidade familiar e classes sociais como parte de uma mesma cadeia, dentre outros), e que se vê defronte de novas ameaças decorrentes da própria mudança de método produtivo. (BECK, Ulrich. La sociedade del riesgo: hacia una nueva modernidad. Trad. Jorge Navarro, Daniel Jiménez e Maria Rosa Borras, Barcelona: Paidos, 1998, p. 25-30)

${ }^{2}$ Para Blanca Mendoza Buergo, "en las sociedades postindustrialies desarolladas las implicaciones negativas del desarollo tecnológico y del sistema de producción y consumo adquieren entidade propia y amenazan de forma masiva a los ciudadanos, ya que ello propicia la aparición de 'nuevos' riesgos de tal magnitud especialmente de origen tecnológico -, que determina un cambio de época desde la sociedade industrial a un nuevo tipo macrosociológico: el de la sociedad del riesgo." E prossegue: "el binomio riesgo-inseguridad y, por tanto, la aversión al riesgo con la consiguiente aspiración a la seguridad, hace que los individuos reclamen de manera creciente del Estado la prevención frente al riesgo y la provisión de seguridad." (El derecho penal en la sociedad del riesgo. Madrid: Civitas, 2001, p. 24-31). Segundo Pierpaolo Cruz Bottini: "A incorporação dos riscos à atividade de produção leva à intensificação dos âmbitos de periculosidade, repercute nas formas de relação social e interfere na produção de discursos econômicos, sociais e políticos. Este fenômeno decorre, notadamente, das novas características do risco. [...] O risco deixa de ser um dado periférico da organização social para transmutar-se em conceito nuclear, relacionado à própria atividade humana. Se antes se referia a perigos externos e não podia ser gerido por regulamentos ou normas direcionados ao comportamento humano, porque este não era agente ativo em sua produção, no modelo social atual, é criado pela própria organização coletiva, ou seja, tem procedência humana. [...] O risco, assim, torna-se um referencial político. Se a periculosidade decorre do comportamento humano, significa que pode ser controlada por medidas de restrição, por mecanismos de gestão de risco. Mais do que um objeto de análise, o risco e os mecanismos para controlá-lo passam a refletir opções da sociedade em relação ao grau de tolerância destas atividades. A procedência humana do risco abre caminho, portanto, para a coerção de comportamentos que apresentem periculosidades maiores do que as permitidas, fora dos parâmetros indicados pelo gestor público. Quanto maior o risco, mais restritivas as medidas e mais severas as sanções pelo descumprimento dos limites impostos. Nesse contexto, fica aberto o espaço para a incidência do direito penal sobre as condutas arriscadas, produzidas pelo comportamento humano que, cada vez mais, ameaçam bens e interesses fundamentais para a vida em comum." (Crimes de perigo abstrato e princípio da precaução na sociedade de risco. São Paulo: Revista dos Tribunais, 2007, p. 35-36)
} 
Silva Sánchez, em sua obra A Expansão do Direito Penal - aspectos da política criminal nas sociedades pós-industriais, ressalta uma séria de consequências positivas decorrentes do desenvolvimento tecnológico, especialmente no tocante ao incremento do bem-estar individual. O autor, todavia, não se furta a apontar os efeitos negativos de tal nova realidade:

Sem embargo, convém não ignorar suas consequiências negativas. Dentre elas, a que interessa aqui ressaltar é a configuração do risco de procedência humana como fenômeno social estrutural. Isso, pelo fato de que boa parte das ameaças a que os cidadãos estão expostos provém precisamente de decisões que outros concidadãos adotam no manejo dos avanços técnicos: riscos mais ou menos diretos para os cidadãos (como consumidores, usuários, beneficiários de serviços públicos, etc.) que derivam das aplicações técnicas dos avanços na indústria, na biologia, na genética, na energia nuclear, na informática, nas comunicações, etc. Mas, também, porque a sociedade tecnológica, crescentemente competitiva, desloca para a marginalidade não poucos indivíduos, que imediatamente são percebidos pelos demais como fonte de riscos pessoais e patrimoniais. ${ }^{3}$

É certo, todavia, que o direito penal clássico não é suficiente para enfrentar, de forma eficiente, os novos conflitos decorrentes dessa sociedade do risco, fato que impulsionou o surgimento de movimentos de expansão do direito penal. ${ }^{4}$

Tais movimentos têm como característica a flexibilização das estruturas do direito penal clássico, especialmente no tocante a seus princípios de garantia. Como consequência dessa quebra de paradigmas, decorreu a necessidade de tutela de bens jurídicos supra-individuais e a criação de tipos penais de perigo abstrato.

Diante desse novo cenário, podem, em linhas gerais, ser identificados dois posicionamentos dogmáticos distintos. O primeiro preza pela função do direito penal como proteção subsidiária e repressiva de bens jurídicos essenciais, seguindo aos princípios de garantia. O segundo sustenta a flexibilização da dogmática e das regras de atribuição de

\footnotetext{
${ }^{3}$ SILVA SÁNCHEZ, Jesus-María. A expansão do direito penal. Trad. Luiz Otavio de Olivaira Rocha. São Paulo: Revista dos Tribunais, 2002, p. 29

4 “"...] não é nada difícil constatar a existência de uma tendência claramente dominante em todas as legislações no sentido da introdução de novos tipos penais, assim como um agravamento dos já existentes, que se pode encaixar no marco geral da restrição, ou a 'reinterpretação' das garantias clássicas do Direito Penal substantivo e do Direito Processual Penal. Criação de novos 'bens jurídico-penais', ampliação dos espaços de riscos jurídico-penalmente relevantes, flexibilização das regras de imputação e relativização dos princípios político-criminais de garantia, não seriam mais do que aspectos dessa tendência geral, à qual cabe referir-se com o termo 'expansão'. (Ibidem, p. 21)
} 
responsabilidade, defendendo a tutela de bens jurídicos supra-individuais e o controle de novos fenômenos de risco. ${ }^{5}$

Schünemann sustenta que ao direito penal cumpre a defesa das bases de subsistência da sociedade, atual e futura. Dentro desse contexto se encaixam os bens jurídicos garantes da subsistência de todos os demais bens, como, por exemplo, o meio ambiente. $^{6}$

Como contraponto, a posição de Hassemer, segundo a qual o direito penal deve sempre proteger a interesses imediatos dos indivíduos com base em fins políticocriminais. Para o autor, a finalidade do direito penal não é a seguridade geral ou a diminuição de um risco social, mas sim a imputação de fatos puníveis a uma pessoa. Nesse contexto, a tutela de interesses gerais somente ganharia relevância penal quando corresponderem a interesses imediatos dos indivíduos. ${ }^{7}$

Tal posicionamento, por assim dizer mais cauteloso, é sustentado principalmente pelos teóricos da chamada Escola de Frankfurt, dentre os quais destacamse, além do próprio Hassemer, Prittwitz, Lüderssen, Herzog e Albrecht ${ }^{8}$.

\footnotetext{
${ }^{5}$ MACHADO, Marta Rodriguez de Assis. Sociedade do Risco e Direito Penal: uma avaliação de novas tendências político-criminais. São Paulo: IBCCRIM, 2005, p. 179

${ }^{6}$ SCHÜNEMANN, Bernd. Sobre la dogmática y la política criminal del derecho penal del médio ambiente. Cuadernos de Doctrina y Jurisprudencia Penal. Buenos Aires, n. 2-9a, Set. 1999, p. 627-653

${ }^{7}$ HASSEMER, Wilfried. Lineamentos de una teoria personal del bien jurídico. Trad. Patrícia S. Ziffer. In: DoctrinaPenal. Buenos Aires, n. 12, abr-set. 1989, p. 275-285

${ }^{8}$ Conforme apontado por Augusto Silva Dias, os penalistas da chamada "Escola de Frankfurt "rejeitam todas essas manifestações consideradas típicas do Direito Penal do risco e admitem a intervenção penal no âmbito dos grandes riscos apenas nos confins do modelo liberal, assente na proteção de bens jurídicos individuais tangíveis, na restrição da responsabilidade penal às pessoas singulares e em critérios de imputação rigorosamente individuais". (Protecção Jurídico-Penal de interesses dos consumidores. $2^{\mathrm{a}}$ Edição policopiada das "Lições aos Cursos de Pós-graduação em Direito do Consumo e Direito Penal Econômico e Europeu, Faculdade de Direito da Universidade de Coimbra, 2000, p. 19. Apud. FERNANDES, Paulo Silva, Globalização, "Sociedade de Risco" e o futuro do Direito Penal. Coimbra: Almedina, 2001, p. 73-74). Paulo Silva Fernandes, por sua vez, oferta crítica à posição da Escola de Frankfurt, ao preconizar que: "O ponto de vista acentuadamente conservador em que radica a posição preconizada pelos autores da "escola de Frankfurt' - que visam, numa palavra, salvaguardar o Direito Penal das novas 'intempéries', expondo-o silente e (praticamente) imóvel na torre de marfim dos seus traços clássicos de tutela, atirando para outros discursos punitivos, não-penais, portanto (leia-se, v,g, direito administrativo), ou até para meios de intervenção não-jurídicos a resposta aos novos desafios inerentes à sociedade de risco - não nos parece, contudo defensável. Sinteticamente - não colocando obviamente a funcionalização e desformalização do direito penal de lado, como se de meras ilusões se tratassem -, o direito penal não deve virar as costas aos novos desafios. Desde logo, seria impensável excluir o Direito Penal da missão de controle destes riscos. Isto desde que se mantenha a atenção, logicamente, nos limites impostos pelo exagero, isto é, não se deve buscar
} 
Conforme aponta Schünemann, Hassemer e seus discípulos deduzem uma teoria do bem jurídico puramente individualista, denominada como pessoal. Dessa forma, deve-se reduzir o direito penal - caracterizado na modernidade pela contínua criação de novos tipos penais, destinados à proteção de bens jurídicos universais definidos de modo vago e carregados de 'déficits crônicos de execução' - a um direito penal nuclear, devendo ser reconhecidos como bens jurídicos os interesses humanos que efetivamente necessitem de proteção jurídico-penal. Diante de tal posição, os bens jurídicos universais remanescentes somente seriam dignos de tutela penal em razão de um interesse mediato dos indivíduos afetados, de modo que tais bens fiquem acomodados à função de proteção dos indivíduos e delimitados com base nessa mesma função. ${ }^{9}$

Como solução, Hassemer defende um chamado "direito de intervenção", o que representaria a criação de um novo ramo do direito, situado entre o direito penal e o direito administrativo e entre o direito civil e o direito público, orientado a uma função eminentemente preventiva, muito mais flexível quanto às garantias materiais e processuais, e voltado à aplicação de sanções menos graves que a privação de liberdade. A esse direito de intervenção caberia resolver os problemas que o direito penal clássico não tem aptidão para solucionar. Dessa forma, o direito penal ficaria liberado de expectativas de prevenção que não consegue cumprir e que o tornam ineficiente. ${ }^{10}$

Dentro de tão atual debate, merece destaque a proposta de Jesús-María Silva Sánchez, o qual apresenta uma posição que pode ser tida como moderada, não demonstrando apego excessivo aos preceitos do direito penal clássico, mas também não aderindo completamente à flexibilização do direito penal.

o direito penal em excesso." (Globalização, "Sociedade de Risco" e o futuro do Direito Penal. Coimbra: Almedina, 2001, p. 74-75)

${ }^{9}$ Cuestiones básicas del derecho penal en los umbrales del tercer milenio. Lima: Idemsa, 2006, p. 98-99

${ }^{10}$ HASSEMER, Winfried. Perspectivas del derecho penal futuro. Revista Penal. n. 1. Barcelona: 1.998, p. 37-41. À posição de Hassemer, Paulo Silva Fernandes opõe a seguinte crítica: "[...] esta parece ser uma inversão perigosa do princípio da subsidariedade, que parece não poder contar com a nossa concordância. Ademais, coloca sérios problemas, pensamos, ao nível de um princípio de proporcionalidade, sendo mesmo um direito algo discricionário, com dois pesos e duas medidas, estes de muito duvidosa - ou pelo menos altamente discutível - propriedade em relação às escolhas a fazer. Por último, peca ao desfigurar os contornos de um direito penal que, ao invés, pretende preservar num limbo da intocabilidade artificial". (Globalização, 'sociedade de risco' e o futuro do direito penal - panorâmica de alguns problemas comuns. Coimbra: Almedina, 2001, p. 78) 
Nega o autor espanhol a plena expansão do direito penal, repudiando a flexibilização de princípios político-criminais, ao mesmo tempo em que rejeita o retorno ao direito penal clássico frente a esses novos riscos. Diante desse dilema, propõe a adoção de um direito penal de duas velocidades, segundo o qual devem ser mantidos os preceitos do direito penal clássico para um chamado "núcleo duro". Em contrapartida, no tocante a esses novos riscos, defende o autor a possibilidade de flexibilização dos princípios penais, desde que reste afastada a possibilidade de aplicação de pena privativa de liberdade, ficando a aplicação desta restrita à primeira classe de riscos. ${ }^{11}$

Pois é justamente dentro desse embate dogmático que está inserida a tutela penal do Mercados de Capitais, quer por sua contemporaneidade, quer por sua natureza dinâmica, não se podendo negar sua extrema relevância para a manutenção da estabilidade e segurança das relações econômicas, tão cara ao mundo atual.

\subsection{Globalização, expansão do mercado de capitais e incremento do direito penal econômico}

Desde sempre o homem se caracterizou pela necessidade de movimentos de expansão. São diversos os casos verificados desde a antiguidade que denotam a necessidade dos povos em ampliar territorialmente seus interesses. Inúmeros foram os povos que, por meio da utilização da força, ampliaram suas áreas de domínio com fins de expandir não apenas sua influência política; mas, principalmente, sua dominação econômica. Tais exemplos vão desde os antigos povos do Oriente, passando pelo Império Romano e pela dominação britânica.

Como exemplos mais precisos de tais movimentos, a expansão de domínios decorrente das grandes navegações, iniciadas por Portugal e Espanha, e logo seguidas por Inglaterra, França e Holanda.

Indissociável da evolução tecnológica, essa expansão, também denominável de "mundialização", apresentou sensível crescimento após a Revolução Industrial e a era das colonizações da África e Oriente.

${ }^{11}$ A expansão do direito penal. Trad. Luiz Otavio de Oliveira Rocha. São Paulo: Revista dos Tribunais, 2002 
A partir do século XX se verifica um notável aperfeiçoamento nas relações econômicas mundiais, com a criação de taxas flutuantes de câmbio e uma maior interdependência entre nações; tendo como base não mais a força, mas sim a economia. Nota-se assim, que o "fenômeno globalizador" não vem a ser nenhuma novidade.

Ocorre que, com o notável e veloz desenvolvimento tecnológico observado desde a década de 1.980, especialmente após o surgimento da internet, a noção de Nação, especialmente no contexto econômico, passa a ganhar contornos de menor significância.

Fato é que o aperfeiçoamento desse fenômeno de "mundialização", o que hoje denominamos "globalização", está diretamente ligado à idéia de eliminação de fronteiras nacionais. ${ }^{12}$

Para Ulrich Beck, globalidade significa a vida em uma denominada sociedade mundial, caracterizada como a totalidade das relações sociais que não estão integradas, nem tampouco são determinadas ou determináveis na política do Estado-nação. O termo mundial, por sua vez, deve ser lido como pluralidade, diversidade. ${ }^{13}$

Essa eliminação de fronteiras econômicas, por outro lado, não representa a eliminação da soberania dos Estados, que deixam de controlar diretamente os atores econômicos, passando a regular os mercados, impondo limites à livre operação destes, a fim de evitar um colapso generalizado.

\footnotetext{
${ }^{12}$ Conforme assevera Renato de Mello Jorge Silveira: "Especialmente a partir das últimas três décadas do século $\mathrm{XX}$, as interações transnacionais conheceram uma magnitude antes não sonhada. $\mathrm{O}$ horizonte passa a de delinear, qual o vaticínio do Orwell. O mundo mostra-se seccionado em comunidades várias, como a União Européia, a Nafta, o Mercosul e a Alca. Como afirma Boaventura de Sousa Santos, a grande amplitude e profundidade das novas relações suprenacionais acabaram por criar, segundo muitos autores, o que se tem por uma quebra de anteriores formas de interação fronteiriças, a qual se pode chamar 'globalização', 'formação global', 'cultura global', 'sistema global', 'modernidades globais', 'processo global', culturas da globalização', ou 'cidades globais'. Poderia mesmo, genericamente, ser qualificada como uma intensificação das relações em escala mundial, o que, através de um processo dialético, acaba por alterar os acontecimentos em forma contínua". Direito Penal Econômico como Direito Penal de perigo. São Paulo: Revista dos Tribunais, 2006, p. 50-51

${ }^{13}$ ¿Que és la globalización?, Barcelona, Paidos, 1998, p. 28-29
} 
Naturalmente, o Mercado de Capitais tem papel fundamental nesse movimento de globalização; ${ }^{14}$ sendo, inclusive, nos dizeres de Martin Albrow, um dos catalisadores dessa eliminação de fronteiras econômicas:

[...] globalização é uma palavra que ficou associada à dissolução das barreiras nacionais à operação de mercados de capital que teve início no começo dos anos 80. Isso resultou em negócios simultâneos nos principais mercados de Nova York, Londres, Tóquio e Frankfurt, de tal forma que o movimento dos mercados se encontra evidentemente fora do âmbito de controle de qualquer agência. ${ }^{15}$

Ante o incremento das relações econômicas em nível internacional, restou evidentemente facilitada uma maior internacionalização dos mercados financeiros e de valores mobiliários. Esta internacionalização dos mercados de valores mobiliários se manifesta por meio de uma extensão das atividades dos emissores, dos investidores e dos intermediários para além de suas fronteiras nacionais. As companhias, especialmente grandes empresas e conglomerados multinacionais procuram emitir seus papéis nos mercados de mais de um país; aumentando, em consequência, suas possibilidades de captação de recursos. Os investidores, notadamente aqueles de cunho institucional, por sua vez, buscam novas oportunidades de ganhos e uma maior diversificação de riscos econômico-financeiros. Em alguns casos, como nos Estados Unidos da América, os mercados estendem suas atividades para além de suas fronteiras, permitindo a participação de empresas emissoras e investidores estrangeiros, e os intermediários buscam clientes fora de seus países de origem, oferecendo valores mobiliários de procedências diversas.

Tal internacionalização dos Mercados de Capitais, sem sombra de dúvidas, traz uma série de benefícios em diversos planos, e é favorecida pela natureza dinâmica das operações com valores mobiliários.

\footnotetext{
${ }^{14}$ Conforme aponta Paul Krugman, “[...] seja qual for a medida utilizada, a escala de transações no mercado internacional de capitais cresceu mais rapidamente do que o PIB mundial desde a década de 70. Um dos principais motivos foi que os países, começando pelos industrializados, pouco a pouco reduziram as barreiras aos fluxos internacionais de capitais privados. (KRUGMAN, Paul R.; OBSTFELD, Maurice. Economia Internacional: teoria e política. Trad. Eliezer Martins Diniz. São Paulo: Pearson Addison Wesley, 2005, p. 476)

15 "Globalização", Dicionário do Pensamento Social do Século XX, Rio de Janeiro, Jorge Zahar Editor, 1996, p. 340
} 
Todavia, consoante afirma Esther Hernandéz Sainz, ${ }^{16}$ gera uma série de situações negativas, como a facilitação de crises bursáteis, ${ }^{17}$ provoca uma certa insegurança jurídica em torno da regulação aplicável às transações internacionais, e aumenta a possibilidade de realização de práticas transfronteiriças de ilícitos no âmbito do mercado de capitais. ${ }^{18}$

No Brasil, até 1.994, prevaleceu uma orientação protecionista do mercado financeiro e de capitais, relativizada a partir de 1.995, com base no art. 52 do Ato de Disposições Constitucionais Transitórias, quando se deu um incremento no sistema financeiro pátrio, com a permissão governamental para venda de bancos nacionais para instituições financeiras estrangeiras e para a abertura de subsidiárias de bancos internacionais. O país passa, então, a ter um mercado exposto ao capital estrangeiro, situação que não divergiu quanto ao Mercado de Capitais.

Notadamente nos últimos três anos, verificou-se um verdadeiro incremento do Mercado de Capitais no Brasil, com um aumento significativo no volume de negócios e o lançamento de papéis de companhias nacionais em bolsas no exterior, sem contar o significativo crescimento no número de empresas nacionais que abriram seu capital em bolsa de valores, e outro grande movimento de fusões e aquisições. Surge, pois, a necessidade de se verificar e analisar os instrumentos legais de controle do Mercado de Capitais.

Outro ponto de destaque diz respeito à já mencionada internacionalização dos papéis de companhias brasileiras em bolsas de valores estrangeiras, tornando os administradores de companhias nacionais e investidores brasileiros, por vezes, sujeitos à regulação, administrativa e penal, dos Mercados de Capitais, provocando uma verdadeira internacionalização do direito penal com relação a tal mercado, aspecto que também será apreciado no curso do presente trabalho.

\footnotetext{
${ }^{16}$ HERNÁNDEZ SAINZ, Esther. El abuso de información privilegiada en los mercados de valores. Pamplona: Thomson, 2007, p. 67

17 Ana María Prieto Del Pino fala em verdadeiro "efeito dominó", ou, em outras palavras, a oscilação das cotações em um mercado levando ao mesmo efeito em outros, como o ocorrido com a bolsa de valores de Hong Kong em 28 de outubro de 1.997. (PRIETO DEL PINO, Ana María. El Derecho Penal ante el uso de información privilegiada en el mercado de valores. Navarra: Editorial Arazandi, 2004, p. 81, nota 92).

18 Como exemplos: o oferecimento de valores mobiliários sem a devida supervisão de autoridades reguladoras, a prestação de serviços sem a devida autorização, a difusão de informações falsas, a manipulação das cotações e o uso de informação privilegiada.
} 
A diminuição do papel intervencionista do Estado, como decorrência natural do processo de globalização, acaba por trazer à baila situações antagônicas no que tange à regulação jurídica da sociedade em geral, mais especificamente, dos mercados.

Tem-se, pois, como consequência clara da globalização, a eliminação de fronteiras econômicas, a já mencionada redução do papel intervencionista do Estado e o desenvolvimento de um arcabouço de regramentos paralelos ao direito dos Estados (lex mercatoria), simplificador das relações jurídicas e quiçá mais adequado à agilidade demandada por esta realidade globalizada. ${ }^{19}$

Por outro lado, no campo do Direito Penal, verifica-se movimento absolutamente inverso. ${ }^{20}$ Conforme assinala Luis Gracia Martín, ${ }^{21}$ é "fato evidente de que o fenômeno da globalização dá lugar, ao mesmo tempo, ao surgimento de condições específicas para a prática de uma nova criminalidade ou delinqeência associada à globalização", todavia, destaca o professor espanhol, "apesar da importância de seus aspectos culturais e políticos, a globalização é um fenômeno de significado fundamentalmente econômico. Por isso, não surpreende que a criminalidade da globalização tenha um caráter, por um lado, fundamentalmente econômico em razão de seu conteúdo".

Silva Sanchéz, na mesma esteira, apregoa que a globalização gera um duplo efeito sobre a delinqüência:

Por um lado - ainda que isso interesse aqui em menor medida -, dão lugar a que determinadas condutas tradicionalmente contempladas como

\footnotetext{
${ }^{19}$ FARIA, Eduardo José. O judiciário após a globalização. Revista brasileira de ciências criminai. Ano 4, n. 26, São Paulo: Revista dos Tribunais, p. 162.

${ }^{20}$ Para Cláudio do Prado Amaral, "[...] a tarefa de preservação da ordem pública deve ser feita diante de uma realidade em que os bolsões de excluídos e a desigualdade estão ampliados pela globalização. Para se desincumbir dessa tarefa o Estado tem reformulado os seus esquemas de controle e prevenção de delitos. $\mathrm{O}$ Estado passou a incorporar uma política criminal voltada à solução das situações criadas pela ausência das respectivas políticas distributivas e compensatórias que seriam devidas. Segue-se, então, que o Estado criminaliza e persegue as situações marginais criadas pela globalização, ampliando o caráter repressivo de suas normas penais, desconsiderando os fatores políticos, socioeconômicos e culturais inerentes aos comportamentos que pretende qualificar como ilícitos penais. (Bases teóricas da ciência penal contemporânea. São Paulo: IBCCRIM, 2007, p. 55.

${ }^{21}$ GRACIA MATÍN, Luis. Prolegômenos para a luta pela modernização e expansão do Direito Penal e para a crítica do discurso de resistência. Trad. Érica Mendes de Carvalho. Porto Alegre: Sérgio Antonio Fabris Ed., 2005, p. 66, tradução nossa.
} 
delitivas devam deixar de sê-lo, pois o contrário se converteria em um obstáculo às próprias finalidades perseguidas com a globalização e a integração supranacional. Em efeito, condutas violadoras de barreiras e controles estatais à livre circulação passam de puníveis a não-puníveis. [...] Mas, por outro lado, os fenômenos econômicos da gloalização e da integração econômica dão lugar à conformação de modalidades novas de delitos clássicos, assim como à aparição de novas formas delitivas. [...] Além disso, gera a aparição de uma nova concepção de objeto do delito, centrada como fenômeno marginal; em particular, os elementos de organização, transnacionalidade e poder econômico. Criminalidade organizada, criminalidade internacional e criminalidade dos poderosos são, provavelmente, as expressões que melhor definem os traços gerais da delinqüência da globalização. ${ }^{22}$

Pois é justamente dentro de tal cenário de verificação de novos riscos penais, inseridos num contexto de globalização como fenômeno essencialmente econômico, que se verifica, especialmente nas últimas décadas, um destacado incremento do que se pode chamar de direito penal econômico, ou também, direito penal da empresa aqui tratados como sinônimos por mera questão de simplificação ${ }^{23}$.

Tal fenômeno verificou-se no Brasil, principalmente na década de 1.990 em diante, como um movimento de verdadeira inflação legislativa, motivado não apenas pelos inéditos cenários decorrentes do mundo globalizado; mas também pela brutal interferência

\footnotetext{
${ }^{22}$ Op. cit., p. $79-80$

23 "En la sociedad actual tiene uma gran relevância todo lo relacionado con el mundo económico, y el sujeto económico de mayor trascendencia es la gran empresa o sociedad mercantil. Ello está vinculado a la idea cada vez más evidente de que la sociedad moderna se caracteriza, entre otros aspectos, por ser una sociedad de organizaciones. El mercado tiene efectos perniciosos (para la vida o la salud de consumidores o trabajadores o para el medio ambiente). En algunas ocasiones los daños que se generan se derivan de la actividad de empresas o sociedades mercantiles concretas y, en esa medida, pueden generar responsabilidad penal”. FEIJOÓ SÁNCHEZ, Bernardo. Derecho penal de la empresa e imputación objetiva. Madrid: Editorial Reus, 2007, p. 13) Consoante apregoa Luis Gracia Martín: “[...] deve-se reconhecer que o Direito penal econômico e do meio ambiente, em realidade, tem que ser configurado e compreendido em usa maior parte também como Direito penal da empresa. Daí porém, deve-se deduzir ademais que o critério da comissão de um fato delitivo no curso da realização de uma atividade econômica de uma empresa tem por si mesmo a suficiente vis atractiva como para que aquele, independentemente de qual seja sua natureza por razão do bem jurídico ou do modo de ataque, tenha que ser incluído no Direito penal econômico e ambiental em razão de que este, como foi dito, deve ser compreendido essencialmente como Direito penal da empresa. De acordo com o exposto, o Direito penal da empresa, ou seja, o conjunto de regulamentos jurídico-penais relativos aos fatos delitivos cometidos no exercício de uma atividade empresarial, tem que ser reconhecido também como manifestação típica - e ademais, de grande importância e transcendência - do Direito penal moderno". (Op. cit., p. 63-64) Renato de Mello Jorge Silveira trata de delimitar os conceitos de direito penal econômico e criminalidade de empresa. O primeiro, como um "Direito Penal dos poderosos", incumbe-se da tutela da ordem econômica, entendida, em sentido amplo, como "a regulação jurídica da produção, distribuição e consumo de bens de serviço", e, em sentido estrito, "como a regulação jurídica do intervencionismo estatal na economia". Já a criminalidade de empresa é entendida como aquela relacionada a atos delitivos praticados por "grupo de pessoas organizadas hierarquicamente e com ideal de divisão de funções". Trata ainda de classificar tal classe de criminalidade como a mais importante do campo econômico". (Direito penal econômico como direito penal de perigo. São Paulo: Revista dos Tribunais, 2006, p. 24-31)
} 
dos meios de comunicação na opinião pública, refletidos quase que imediatamente na produção do legislador.

Como decorrência, a edição de inúmeras Leis especiais que visam à tutela dos mais diversificados ramos da atividade econômica, reflexo de tais novos riscos, como nas esferas ambiental, tributária, concorrencial, consumerista, e, mais recentemente, com a reforma do Mercado de Capitais, em 2.001, tendo como consequência a criação de tipos penais relacionados a suas atividades.

Cabe, todavia, transcrever relevante ressalva anotada por Renato de Mello Jorge Silveira e Alamiro Velludo Salvador Netto:

O Direito Penal Econômico, dessa forma, mesmo que esculpido com fragilidade dentro de uma forma abstrata, não deve permitir que se flexibilizem as garantias liberais conquistadas. [...] Embora pareça correta a assertiva de que o Direito Penal não pode se mostrar alheio a tudo o que está a se dar no mundo, as formulações atuais do Direito Penal Econômico, por onde se procura um controle social, mormente através de termos abstratos e em forma antecipada, destoantes de toda a construção liberal, parecem um tanto temerárias. ${ }^{24}$

Essa tentativa do legislador em combater tais novas espécies de criminalidade, motivado mormente em aplacar os anseios da opinião pública, nem sempre, ou quase nunca, reflete uma preocupação com a utilização da melhor técnica legislativa, implicando, no mais das vezes, na utilização simbólica do direito penal para aplacar sentimentos sociais de insegurança.

\subsection{A questão comunitária e a segurança dos mercados}

O apontado cenário de "mundialização", ou "globalização", da economia, ganha contornos especiais a partir da divisão do planeta em blocos econômicos, como a Comunidade Européia, o NAFTA, a ALCA e o Mercosul. Tratam-se de verdadeiros espaços geográficos delitivos, nos quais são desenvolvidos fenômenos de criminalidade, como, por exemplo, no âmbito empresarial.

${ }^{24}$ SILVEIRA, Renato de Mello Jorge; SALVADOR NETTO, Alamiro Velludo. "Sarbanes-Oxley Act" e os vícios do Direito Penal Globalizado. Revista Ultima Ratio. Vol. 1. Rio de Janeiro, 2006, p. 199-200 
Especial destaque merece a União Européia, estabelecida a partir de 1.992 por meio do Tratado de Maastricht, contando atualmente com vinte e sete estados membros. Devido ao seu notório pioneirismo frente aos demais blocos, a Comunidade Européia está, hoje, nitidamente mais avançada no âmbito legislativo comunitário. ${ }^{25}$

Nesse contexto, Luis Gracia Martín faz referência a um Direito penal da União Européia, o qual justifica ante a delimitação de um espaço geográfico comunitário e à existência de um mercado comum, o que faz com que a criminalidade seja levada a cabo "por meio da utilização de instrumentos e instituições europeus específicos", e cujos danos produzidos "afetam também interesses europeus específicos". Afirma o autor que em termos concretos, constata-se o aparecimento de "bens jurídicos europeus claramente diferenciados dos reconhecidos nos âmbitos nacionais específicos de cada um dos Estados membros". 26

Prossegue o autor referindo a existência de duas espécies distintas de bens jurídicos europeus, uma primeira denominada "bens jurídicos europeus institucionais", “vinculados à existência e ao exercício dos poderes e competências próprios da União Européia", e um segundo grupo, composto por "bens jurídicos europeus que surgem em consequência do exercício da atividade normativa concreta da União sobre determinados setores, geralmente econômicos, que se encontram submetidos à sua competência normativa". ${ }^{27}$

E conclui:

\footnotetext{
25 Acerca do tema vide: MACHADO, Maíra Rocha. Internacionalização do direito penal: a gestão de problemas internacionais por meio do crime e da pena. São Paulo: Editora 34, 2004, p. 52 e ss. Vide também: ESTELLITA, Heloísa. Integração regional $e$ direito penal. Tese de doutorado apresentada à Faculdade de Direito da Universidade de São Paulo em 2004, p. 20 e ss.

${ }^{26}$ Op. cit., p. $72-73$

${ }^{27}$ Idem, p. 73-74. Afirma ainda o autor: "São diversos os motivos, técnicas e procedimentos de europeização do Direito penal dos Estados membros, cada um com sua própria problemática específica, mas com um fundamento comum que radica em três princípios básicos que informam as relações entre o Direito supranacional e o nacional de cada Estado: primazia do Direito europeu sobre o interno, direta aplicabilidade do primeiro nos Estados membros, e um mandato de interpretação (a aplicação) do Direito nacional de conformidade com o europeu". Trata-se, para o autor, de verdadeiro "dever de lealdade" dos Estados membros frente a esse direito europeu, "que obriga negativamente a não produzir legislação nacional incompatível com ele, e, positivamente, a estender os tipos penais nacionais à proteção de bens jurídicos europeus, seja no momento de sua criação pelo legislador, seja no de sua interpretação e aplicação judicial". (Ibidem, p. 76-77) Vide também MACHADO, Maíra Rocha. Op. cit., p. 59-60
} 
[...] a maior parte do Direito penal da União Européia, seja o introduzido pela via atualmente vigente de europeização dos Direitos nacionais, seja o Direito penal (supranacional) europeu do futuro, tem como conteúdo tipos penais do Direito penal econômico e, eventualmente - por exemplo no Corpus iuris - normas da Parte Geral que implicam a adaptação das regras de imputação transnacionais à criminalidade econômica e, sobretudo, econômico-empresarial. O Direito penal da União Européia está orientado para a proteção de bens jurídicos europeus, os quais têm um conteúdo essencialmente econômico, e por isso pode-se dizer que o Direito penal europeu é fundamentalmente um Direito penal econômico e da empresa". ${ }^{28}$

Vale ressalvar, consoante aponta Maíra Rocha Machado, que não cabe ao legislador comunitário estabelecer sanções, tão somente "exigir que sejam tomadas "medidas adequadas", sem especificar o alcance e a natureza das sanções, deixando aos Estados membros a possibilidade de optarem entre sanções penais, administrativas ou civis". 29

Assim, a União Européia, tendo enfrentado um debate acerca da segurança do fluxo de capitais entre seus membros, tratou de desenvolver um arcabouço jurídico com fins de proteger não só os mercados de capitais dos países integrantes do bloco, como estabeleceu a noção de "mercado único para os serviços financeiros" como "fundamental para o crescimento económico e a criação de emprego na Comunidade". ${ }^{30}$

Um 'mercado de capitais europeu' passou a ser paulatinamente regulamentado em termos comunitários desde meados da década de 1.970, ainda por meio de normativas da Comunidade Econômica Européia, com especial destaque para a edição do Código Europeu de Boa Conduta, de 1.977, e para a Diretiva 79/279/CEE, e ganha corpo em 1.989, por meio da Diretiva 89/592/CEE, que trata especificamente do insider trading (uso indevido de informação privilegiada), definindo tal prática, delimitando quais as pessoas que poderiam ser consideradas como insiders, e quais as práticas vedadas, estabelecendo ainda a cada um dos Estados Membros competência para a designação de autoridades reguladoras. ${ }^{31}$

\footnotetext{
${ }^{28}$ Ibidem, p. 85

${ }^{29}$ Op. cit., p. 64

${ }^{30}$ Considerando n. 1 da Diretiva 2003/6/CE

${ }^{31}$ PROENÇA, José Marcelo Martins. Insider trading - regime jurídico do uso de informações privilegiadas no mercado de capitais. São Paulo: Quartier Latin, 2005, p. 242 e ss.
} 
Em 28 de janeiro de 2.003 é editada a Diretiva 2003/6/CE do Parlamento Europeu, especificamente para tratar acerca do abuso de informação privilegiada e da manipulação de mercado, norma esta que se traduziu no mais importante instrumento de regulação da matéria em termos europeus, vigente até os dias atuais, e que teve forte influência sobre os sistemas dos Estados Membros.

Dentre os principais pontos da diretiva em questão, destacam-se alguns pressupostos, expressos por meio de considerandos, que denotam, consoante já referido, uma preocupação de tratamento do mercado financeiro e de capitais como um "mercado único" "integrado e eficiente". ${ }^{32}$ Ademais, estabeleceu como prioridade à regulamentação da matéria a garantia do bom funcionamento dos mercados e a confiança do público nos mesmos, como "condição essencial do crescimento económico e da prosperidade". 33

Destaca-se ainda uma preocupação do legislador comunitário com o incremento dos riscos decorrentes do avanço tecnológico ${ }^{34}$ e com a incompletude e falta de uniformidade entre as legislações dos Estados membros, fator que acarreta incerteza quanto aos conceitos, definições e sua respectiva aplicação. ${ }^{35}$ Os objetivos da norma podem ser, pois, resumidos pelo disposto no considerando n. 12:

$\mathrm{O}$ abuso de mercado abrange o abuso de informação privilegiada e a manipulação de mercado. O objectivo da legislação contra o abuso de informação privilegiada é o mesmo da legislação contra a manipulação de mercado: garantir a integridade dos mercados financeiros comunitários e promover a confiança dos investidores nos mesmos. Por conseguinte, é aconselhável adoptar regras conjuntas para combater tanto o abuso de informação privilegiada como a manipulação de mercado. Uma directiva única garantirá o mesmo enquadramento em toda a Comunidade para a atribuição de responsabilidades, aplicação da legislação e cooperação.

\footnotetext{
${ }^{32}$ Considerando n. 2

33 Idem

${ }^{34}$ Considerando n. 10: “As inovações financeiras e técnicas aumentam os incentivos, meios e oportunidades de abuso de mercado, através dos novos produtos, das novas tecnologias, de um número cada vez maior de actividades transfronteiriças e da utilização da internet".

${ }^{35}$ Considerando n. 11: "O actual enquadramento jurídico comunitário para proteger a integridade do mercado está incompleto. Os requisitos legais variam consoante os Estados-Membros, o que frequentemente coloca os agentes económicos numa situação de incerteza quanto aos conceitos, definições e aplicação. Em alguns Estados-Membros não existe legislação em matéria de manipulação de preços e de divulgação de informação enganosa".
} 
Nota-se, assim, a especial preocupação do legislador europeu em garantir a segurança do mercado e dos investidores em termos comunitários.

Por outro lado, tem especial destaque a influência do sistema regulatório norte-americano em relação aos demais blocos econômicos e países, tendo em vista terem sido os Estados Unidos da América o berço da regulação do Mercado de Capitais, e cujo modelo, portanto, foi influenciador da regulação adotada mundo afora, o que será analisado com maior profundidade nos capítulos 2, 3 e 4 da presente dissertação.

Não se pode negar, ademais, a relevância do Mercosul para o mercado brasileiro e, principalmente, o potencial que representa em termos de oportunidades de investimento, tanto de companhias nacionais em bolsas dos demais membros, como o inverso, na medida em que, sem sombra de dúvidas, em termos de macroeconomia e, especificamente, do Mercado de Capitais, o Brasil representa significativa liderança dentro do bloco sul-americano. Contudo, em termos legislativos, o Mercosul caminha a passos lentos no tocante à tutela comunitária do fluxo de capitais entre os países membros; ${ }^{36}$ bem como para uma harmonização da legislação penal em geral ${ }^{37}$.

Diante do exposto, fica evidenciado o avanço europeu em termos de uma regulamentação comunitária do Mercado de Capitais, cuja finalidade é harmonizar as diversas legislações penais dos Estados membros, de modo a buscar maior segurança nas relações de mercado frente às possibilidades de novas formas de delinquência decorrentes do avanço tecnológico, com especial destaque a uma busca pela transparência das informações e estabelecer a confiança dos investidores. Tal modelo, por seu turno, poderá

\footnotetext{
${ }^{36}$ José Marcelo Martins Proença apresenta as principais iniciativas do MERCOSUL com relação à regulação do Mercado de Capitais, ocorrida principalmente a partir de 1994, após a assinatura do Protocolo de Ouro Preto, as quais têm por base regular requisitos mínimos para um funcionamento harmônico nos Mercados de Capitais dos países membros, com especial destaque para o fluxo de informação. O autor destaca ainda que, não obstante a escassez de iniciativas do bloco sul-americano para uma regulação harmônica do Mercado de Capitais, tanto Argentina como Uruguai apresentam regulações próprias, especialmente no tocante à prática de insider trading (Op. cit., p. 260 e ss.)

${ }^{37}$ Heloísa Estellita aponta a aprovação, em 2.001, do "Programa de Ação do MERCOSUL de Combate a Ilícitos no Comércio Internacional", o qual prevê medidas administrativas em matéria de cooperação aduaneira, e estabelece como diretriz a adoção de "medidas para a harmonização das legislações dos Estados Partes, relativas às penalidades a serem impostas às empresas e pessoas envolvidas na prática de contrabando, falsificação e qualquer outro ilícito". Trata-se, pois de iniciativa voltada às questões de comércio exterior, especialmente o ilegal, não guardando relação direta com os Mercados de Capitais. A autora esclarece ainda: “dadas as limitações já vistas em sede de matéria penal, a via principal de interferência na esfera do combate à criminalidade transfronteiriça dá-se no âmbito da cooperação policial e judicial em matéria penal". (Op. cit., p. 186-187)
} 
representar, em seus aspectos positivos e negativos, grande influência em uma futura uniformização da regulação dos demais blocos econômicos, como o Mercosul. 


\section{O MERCADO DE CAPITAIS E SUAS PARTICULARIDADES}

\subsection{Conceito e princípios norteadores}

O conceito do termo "mercado" está diretamente ligado à noção de um ambiente de negócios, derivado do latim mercari, indicativo de lugares em que, na antiguidade, se vendiam ou trocavam gêneros ou víveres.

Em um contexto atual, o termo é aplicado para designar "o conjunto de operações sobre determinada mercadoria, ou certos valores vendáveis [...]. Em sentido econômico é empregado para mencionar a relação estabelecida entre a oferta e a procura de bens e/ou serviços e/ou capitais." 38

Por capital, entende-se "um ativo que gera um rendimento e pode existir na forma de dinheiro, valores mobiliários ou bens reais, mormente na forma de propriedade imobiliária ou parques industriais. Os ativos formados por dinheiro e bens econômicos de valor monetário geralmente são denominados capitais financeiros."39

Modernamente, por mercado de capitais se entende o ambiente de negócios onde são transacionados valores mobiliários. $\mathrm{O}$ mercado de capitais caracteriza-se como um meio para a tomada de crédito, ou mobilização de poupança, em termos econômicos. Diferentemente do sistema bancário, no mercado de capitais essa mobilização de poupança se dá diretamente entre detentor e tomador de recursos. Inexiste a intermediação de uma instituição financeira. Estas atuam somente como intervenientes obrigatórias, não assumindo qualquer risco pelas operações. ${ }^{40}$

\footnotetext{
${ }^{38}$ Enciclopédia Saraiva do Direito. Coord. Prof. Rubens Limongi França. São Paulo: Saraiva, 1977, v. 52

${ }^{39}$ KÜMPEL, Siegfried. Direito do Mercado de Capitais - do ponto de vista do direito europeu, alemão e brasileiro. Rio de Janeiro: Renovar, 2007, p.43

40 Segundo Roberto Quiroga Mosquera: "o mercado de capitais representa o conjunto de operações, realizadas entre pessoas físicas, jurídicas e demais entidades equiparadas, consistentes na transferência de recursos financeiros de forma direta entre detentores e tomadores de capital, no qual as entidades financeiras participam, em regra, como intervenientes obrigatórias nos negócios realizados". (Os princípios informadores do Direito do Mercado Financeiro e de Capitais. Aspectos atuais do Direito do Mercado Financeiro e de Capitais. Coord. Roberto Quiroga Mosquera. São Paulo: Dialética, 1999, p. 270
} 
O mercado de capitais subdivide-se em mercado primário e mercado secundário. $^{41}$ Pelo primeiro, também denominado mercado de emissão, entende-se o primeiro lançamento de ações, debêntures e outros valores mobiliários, pelas companhias para aquisição por parte dos investidores. ${ }^{42}$

\section{Conforme explica Siegfried Kümpel:}

O lançamento de ações pode ocorrer tanto por meio de uma emissão de novas ações para subscrição pública no Mercado primário, trazendo recursos à companhia emissora, quanto pelo lançamento ao público de um lote de ações detido por acionista já existente no Mercado Secundário. Esta última operação é denominada distribuição secundária e não resulta na captação de novos recursos para a companhia, mas para o acionista que se desfaz da posição. Trata-se, particularmente, da venda pública de um lote que se encontra em carteira de intermediários, de acionistas controladores ou de investidores com grande número de ações. $^{43}$

Já por mercado secundário, entende-se o ambiente negocial onde são transacionados os valores mobiliários anteriormente emitidos. Tais negociações se dão entre particulares - pessoas físicas ou jurídicas - e correspondem à circulação dos títulos por meio de vendas e compras repetidas, motivo pelo qual este seguimento do mercado é também denominado mercado de circulação. ${ }^{44}$ Este, por sua vez, está subdividido em bolsas de valores e mercados de balcão.

A doutrina brasileira tradicional define bolsa de valores como "entidades de natureza privada, funcionando sob a forma de associação e tendo por sócios sociedades corretoras" onde, "em período e horário determinado realizam-se diariamente operações com valores mobiliários, basicamente ações, verificando-se o chamado pregão". ${ }^{45}$

\footnotetext{
${ }^{41}$ FORTUNA, Eduardo. Mercado Financeiro. $16^{\mathrm{a}}$ ed. Rio de Janeiro: Qualitymark, 2005, p. 559

${ }^{42}$ KÜMPEL, Siegfried. Op. cit., p. 67-68

${ }^{43}$ Idem, p. 71

${ }^{44}$ Idem, p. 70

${ }^{45}$ BORBA, José Edwaldo Tavares. Direito Societário. $8^{\text {a }}$ ed. Rio de Janeiro: Renovar, 2003, p. 158. Otávio Yazbek observa a necessidade de uma definição mais objetiva, tendo em vista que a expressão apresenta vários sentidos, dentre os quais: "o local em que se encontram os representantes dos compradores e vendedores para apresentar suas ofertas e fechar as operações; a instituição que administra aquele local e os sistemas de negociação nele existentes e que processa as operações ali realizadas; o mecanismo ou sistema adotado para as negociações de um determinado ativo; ou, mais informalmente, o estado das operações bursáteis em um dado período (quando se discute a tendência geral dos negócios, afirmando-se que ela 'subiu' ou 'caiu', por exemplo". (YAZBEK, Otávio. Regulação do mercado financeiro e de capitais. Rio de Janeiro: Elsevier, 2007, p. 137-138)
} 
Cumpre, todavia, ressalvar que tal forma de associação está, atualmente, superada, ante a transformação de tais entidades em sociedades anônimas e sujeitando-as a um regime empresarial, seguindo uma tendência internacional, o que de fato acabou por acontecer no Brasil em 2.008. ${ }^{46}$

Siegfried Kümpel aponta para a ausência de definição legal de bolsa de valores, pelo que se socorre da experiência alemã, apresentando a seguinte definição:

[...] um sistema de negociação regularmente acessível, com períodos curtos entre o fechamento e a abertura para negociação, no qual se possibilita a conclusão de negócios entre os participantes do mercado sobre os objetivos nele negociados, com uma fixação neutra e transparente do preço. ${ }^{47}$

Quanto ao mercado de balcão, este é, por seu turno, também subdividido em duas espécies: organizado e não organizado. Este é formado pelos agentes intermediários que negociam valores mobiliários fora das bolsas de valores, que podem ser instituições financeiras, "sociedades que tenham por objeto a distribuição ou compra para revenda de valores mobiliários, e ainda os agentes autônomos e sociedades que exerçam a mediação na negociação desses títulos". 48

Importante ainda mencionar o chamado novo mercado, que nada mais consiste do que caracterizar uma distinção entre os papéis negociados em bolsa de valores, no tocante à adoção de determinadas regras por parte das companhias emissoras, como, por exemplo, responsabilidade social, ações ambientalmente responsáveis e níveis de governança corporativa diferenciados.

Vistos os principais conceitos, há que analisar os princípios norteadores do mercado de capitais.

\footnotetext{
46 "De um modo geral, tal tendência está relacionada a alguns determinantes econômicos. Isso porque, ante as feições dos mercados atuais e a atuação global dos conglomerados, as bolsas precisaram, para garantir liquidez, atrair novos participantes, o que se daria pela profissionalização de suas estruturas, por ganhos em eficiência e por redução de custos". (YAZBEK, Otávio. Op. cit., p. 140-141)

${ }^{47}$ Op. cit., p. 93

${ }^{48}$ BORBA, José Edwaldo Tavares. Op. cit., p. 160. Ainda sobre o tema, vide: KÜMPEL, Siegfried. Op. cit., p. 163 e ss.
} 
Partindo-se do conceito de que o Direito do Mercado Financeiro e de Capitais constitui um ramo autônomo de direito, constituindo um sistema composto de princípios jurídicos informadores, relevante elencar os pressupostos fundamentais desse ramo do direito, cuja função consiste em orientar e harmonizar todo o sistema.

Nesse diapasão, segundo classificações apresentadas por Roberto Quiroga Mosquera e Fernando Zunzunegui, verifica-se os seguintes princípios: princípio da proteção da mobilização da poupança nacional; princípio da proteção da economia popular; princípio da proteção da estabilidade da entidade financeira; princípio da proteção do sigilo bancário; e, princípio da proteção da transparência de informações. ${ }^{49}$

Consoante verificado, o mercado de capitais consiste em relevante instrumento para tomada de crédito, pelo qual as companhias emissoras de valores mobiliários são financiadas por investidores por meio da mobilização de poupança destes.

Pois é justamente dentro deste espectro que se insere o princípio da proteção da mobilização da poupança nacional. Segundo determina expressamente o artigo 192 da Constituição Federal, "o Sistema Financeiro Nacional deve estar estruturado de forma a promover o desenvolvimento equilibrado do País e a servir aos interesses da coletividade". Trata-se, pois, de imperativo legal, do qual decorre, consoante afirma Roberto Quiroga Mosquera, "que o conjunto de normas jurídicas que regulamentam o mercado financeiro e de capitais deve atender a tal finalidade, qual seja, viabilizar por intermédio de regras jurídicas a mobilização da poupança nacional". ${ }^{50}$

Decorre da mobilização da poupança nacional, outro princípio fundamental do direito do mercado financeiro e de capitais, posto que os recursos financeiros que circulam na economia do país decorrem da existência de tais mercados, advindo grande prejuízo à mobilização da poupança nacional em caso de inadimplência de algum dos participantes do sistema. Tem-se, pois, o princípio da proteção da economia popular, que atuará na orientação do legislador, a fim de que se criem instrumentos efetivos de

\footnotetext{
${ }^{49} \mathrm{O}$ autor espanhol aponta como um princípio informador dos demais princípios citados, um princípio geral de eficiência, segundo o qual o correto funcionamento do mercado financeiro e de capitais somente será alcançável por meio da proteção da poupança nacional, da economia popular, da estabilidade das entidades financeiras e da transparência. (ZUNZUNEGUI, Fernando. Derecho del Mercado Financiero. Madrid: Marcial Pons, Ediciones Jurídicas, 1997, p 27)
} 
regulação e controle das instituições que operam no mercado financeiro e de capitais, evitando-se, dessa forma, a quebra de tais instituições, bem como a prática de ilícitos por parte de seus administradores. O fim pretendido recai, de igual sorte, à consecução dos objetivos apontados no texto do artigo 192 da Carta Magna. ${ }^{51}$

Como contrapartida ao princípio supra referido, o princípio da proteção da estabilidade da entidade financeira, do qual resulta a necessidade de proteção das instituições financeiras responsáveis pela intermediação e/ou viabilização de crédito, nas palavras de Roberto Quiroga Mosquera, "de nada adianta proteger a economia popular se não houver a contrapartida respectiva, qual seja, a proteção da estabilidade das instituições financeiras". 52

O princípio da proteção do sigilo bancário consiste, segundo definição de Roberto Quiroga Mosquera, "na proteção à inviolabilidade de dados e informações atinentes ao mercado financeiro e de capitais; princípio que assegura a proteção das informações privadas e personalíssimas". 53

A despeito da necessidade de tutela das informações íntimas, assim entendidas aquelas que somente dizem respeito à pessoa que realiza qualquer operação no mercado financeiro e de capitais ${ }^{54}$, deve o direito do mercado financeiro e de capitais assegurar a transparência da chamada informação pública. Trata-se aqui do princípio da transparência, também denominado princípio de disclosure, originário do sistema regulatório norte-americano e base fundamental deste sistema.

Trata-se de princípio orientado especialmente à garantia da proteção do investidor, segundo o qual as empresas emissoras de valores mobiliários devem prestar

\footnotetext{
${ }^{50}$ Op. cit., p. 263. Em idêntico sentido: ZUNZUNEGUI, Fernando. Op. cit., p. 27-29

${ }^{51}$ Idem, p. 265-266. Acerca do tema, vide: ZUNZUNEGUI, Fernando. Op. cit., p.29-31

${ }^{52}$ Ibidem. Nesse mesmo sentido: El derecho del mercado financiero se funda en la necessidad de garantizar la estabilidad de las entidades financieras en defensa del normal funcionamiento del mercado financiero. La necessidad de garantizar la estabilidad es más intensa en las entidades de crédito. Estas entidades cumplen una función peculiar y crucial en la economía al suministrar los medios de pago. Se deben prevenir sus crisis para evitar que multipliquen su efecto sobre la economía”. (ZUNZUNEGUI, Fernando. Op. cit., p. 31-32) ${ }_{53}$ Op. cit., p. 271

${ }^{54}$ Acerca do tema: MOSQUERA, Roberto Quiroga, Op. cit., p. 268-269
} 
amplas e completas informações a respeito delas próprias e dos valores mobiliários por elas emitidos. ${ }^{55}$

Pela aplicação de tal preceito, objetiva-se que o investidor esteja munido de informações que lhes possibilitem uma adequada tomada de decisão quanto ao destino de seus investimentos. Segundo aponta Fernando Zunzunegui, "a técnica bursátil exige a divulgação da informação para que os interessados possam adotar uma decisão fundada" 56 Cumpre também importante papel na atuação dos investidores no curso da tomada de decisões em assembléias societárias, e atua como verdadeiro controle de qualidade sobre as sociedades emissoras.

Consoante coloca Júlio Ramalho Dubeux, não se trata da interferência estatal nos negócios privados, mas sim a garantia de um direito de ampla informação para que os investidores conheçam os riscos e as oportunidades a que estão expostos. ${ }^{57}$

Cumpre também importante papel a fim de se buscar a igualdade de condições entre os participantes de tais mercados; propiciando, dessa forma, um ambiente de concorrência leal, motivo pelo qual a divulgação das informações deverá ocorrer de forma eficiente, rápida, e com a maior difusão possível.

O princípio de disclosure assume ainda função subsidiária de proteção ao correto funcionamento do mercado, haja vista que a informação é componente relevante na correta formação dos preços dos valores mobiliários, ${ }^{58}$ e acaba por proteger as próprias empresas emissoras, pois a submissão a práticas de transparência garante o acesso destas ao próprio mercado, o que representa um custo de captação menor daquele disponível no mercado bancário. ${ }^{59}$

\footnotetext{
${ }^{55}$ EIZIRIK, Nelson. O papel do Estado na regulação do mercado de capitais. Rio de Janeiro: IBEMC, 1977, p. 6

${ }_{56}^{56}$ Tradução nossa. Op. cit., 35

${ }^{57}$ DUBEUX, Júlio Ramalho. A comissão de valores mobiliários e os principais instrumentos regulatórios do mercado de capitais brasileiro.Porto Alegre: Sérgio Antonio Fabris Editor, 2006, p. 45

58 " [...] a política de disclosure promove a eficiência do mercado, no sentido de que a cotação dos valores mobiliários publicamente negociados deve refletir apenas as informações publicamente disponíveis. Mercado eficiente, como já dissemos acima, é aquele em que as cotações dos títulos refletem fielmente as informações disponíveis sobre as companhias emissoras e seus valores mobiliários, não sendo as cotações, portanto, o resultado de práticas de manipulação de preços ou de informações privilegiadas”. (Idem, p. 49)

${ }^{59}$ Ibidem, p. 50
} 
Diante do exposto, cumpre destacar que os princípios ora estudados assumem importante papel na identificação do bem jurídico protegido nos crimes contra o mercado de capitais, objeto de análise detalhada no capítulo 4 do presente trabalho.

\subsection{A tradicional regulação dos mercados no Brasil}

As origens do Sistema Financeiro Nacional remontam ao ano de 1.808, mais precisamente com a vinda da família real portuguesa ao Brasil, por conta da invasão do território português pelas tropas de Napoleão.

Nesse mesmo ano são criados a primeira seguradora do país e, principalmente, o primeiro Banco do Brasil, situação que perdurou, com alguns momentos de interrupção, até a proclamação da República. É desse primeiro período a edição do Código Comercial, em 1.850, primeiro sistema legal a disciplinar as atividades bancárias. Em 1.860, dá-se a promulgação da chamada "Lei dos entraves", ${ }^{60}$ cujo objetivo foi o de restringir a atividade de emissão de títulos, usados como forma de pagamento e muito comuns na época.

Nota-se, desde logo, uma preocupação do legislador da época em tutelar as atividades financeiras, com vistas a evitar uma insolvência generalizada.

Ainda nesse período, em decorrência da instalação da Corte portuguesa no Brasil, como uma tentativa de organização dos mercados, surge o conceito de Praça de Comércio, muito similar a um pregão organizado. Nessa mesma fase fretes de navio e mercadorias de importação eram negociados ao ar livre e intermediados por corretores, então chamados de "zangões".

Em 1.845 é fundada a primeira bolsa de valores do Brasil, no Rio de Janeiro e, em 1.851, a Junta dos Corretores, na Bahia, cujas atividades se desenvolviam nos mesmos moldes da Bolsa do Rio de Janeiro. No ano de 1.851 surgem os primeiros textos

\footnotetext{
${ }^{60}$ Lei 1.083 , de 22 de agosto de 1.860
} 
normativos voltados à regulação das atividades dos operadores do mercado de capitais, com a aprovação do regimentos dos corretores do Rio de Janeiro e da Bahia. ${ }^{61}$

O advento da República, já imersa em uma crise financeira de grandes proporções à época, em decorrência de um processo de emissão descontrolada de títulos, o chamado "encilhamento", herança da fase final do Segundo Império, não representou, contudo, significativa alteração nos modelos de regulação da atividade financeira. Do referido período remontam as origens do que viria a ser a Bolsa de Valores de São Paulo, com a criação, em 1.890, da chamada Bolsa Livre, fechada em 1.891 por conta da crise deflagrada pela política do "encilhamento", e, em 1.895, da Bolsa de Fundos Públicos de São Paulo.

Apenas na década de 1.920, com a criação da Inspetoria-geral de Bancos e da Câmara de Compensação, começa a se desenhar o que seria, em um breve futuro, o Sistema Financeiro Nacional.

O período entre 1.930 e 1.945 representa um movimento de expansão e nacionalização do mercado financeiro brasileiro. No ano de 1.934 é fundada a Bolsa Oficial de Valores de São Paulo, e em 1.945, a Superintendência da Moeda e do Crédito SUMOC, "verdadeiro embrião de um banco central". 62

Com o fim da Segunda Guerra Mundial, são iniciados movimentos para a reestruturação e efetiva regulação do seguimento financeiro, culminando, em 1.964, com a promulgação, em 31 de dezembro, da Lei 4.595, responsável pela criação do Conselho Monetário Nacional e do Banco Central do Brasil.

Decerto que, não obstante imperar já o regime imposto pela ditadura militar, referido diploma legal marca a instalação de uma base legal capaz de sustentar um processo de desenvolvimento financeiro necessário, mesmo que os órgãos por ela criados, por razões óbvias, não tenham sido dotados da autonomia desejável. ${ }^{63}$

\footnotetext{
${ }^{61}$ Decreto Imperial no 807 , de 27 de julho de 1.851

${ }^{62}$ YAZBEK, Otávio. Op. cit., p. 258

${ }^{63}$ Idem, p. 259-265
} 
As décadas de 1.970 e 1.980 foram marcadas por imensas dificuldades para o desenvolvimento financeiro do país, sendo maculadas por crises internacionais, como as do petróleo (1.974 e 1.979), bem como por sucessivos planos econômicos e inflação desenfreada.

A partir da implementação do chamado Plano Real, em 1.994, começa a se verificar uma tendência à estabilização econômica, e, como decorrência de tal cenário, somado ao cada vez mais veloz desenvolvimento tecnológico e à relativização das fronteiras econômicas, o Brasil começa a se inserir no contexto de "mundialização" dos negócios, especialmente no que tange ao Mercado de Capitais, havendo, pois, uma real necessidade de atualização e adequação da regulação legislativa dos mercados financeiro e de capitais.

No que toca ao Mercado de Capitais, essa adequação legislativa aos novos tempos nas relações econômicas teve início no ano de 1.997, com a edição da Lei 9.457, que tratou de reforçar os poderes de fiscalização da CVM, incrementando o rigor das sanções administrativas. Segue-se a edição da Medida Provisória n. ${ }^{\circ}$ 1.637/98, que alterou o texto do artigo $2^{\circ}$ da Lei do Mercado de Capitais, ampliando o conceito de valor mobiliário.

Posteriormente, uma nova reforma legislativa do Mercado de Capitais foi implementada pela Lei 10.303/2001, que inseriu significativas mudanças, especialmente no tocante à ampliação de competências da Comissão de Valores Mobiliários e à criação de novos tipos penais, ampliando a tutela do Mercado de Capitais, sendo essa a situação dos dias atuais.

Cumpre aqui estabelecer, de acordo com a doutrina vigente, qual o objetivo da regulação e tutela do Mercado de Capitais, identificando-se, assim, um bem jurídico em sentido amplo, que não se confunde necessariamente com o bem jurídico protegido pela norma penal.

Dessa forma, há que se considerar que é objetivo prioritário do Estado proporcionar o bem-estar da população, assim entendido como "o interesse comum derivado de diversos interesses privados e públicos específicos”. Assim, o detentor desse 
interesse comum é o Estado - compreendido como "completo conjunto de pessoas" - e sua manifestação se dá, dentre outras causas, pela "existência de Mercados de Capitais tão eficientes quanto possível". ${ }^{64}$

Nesse contexto, Siegfried Kümpel, após aprofundado estudo do direito do Mercado de Capitais com base na regulação européia (com especial destaque à Alemanha) e brasileira, aponta ser a capacidade funcional do Mercado de Capitais como o bem jurídico que serve ao interesse público estatal na existência de mercados eficientes:

A necessária proteção da capacidade funcional do Mercado de Capitais requer medidas apropriadas, de maneira que seus vários seguimentos de mercado possam eficientemente cumprir as funções a eles atribuídas. Disso resulta a distinção entre três aspectos muito intrincados da proteção da capacidade funcional: (1) a capacidade funcional institucional, (2) a capacidade funcional operacional e (3) a capacidade funcional alocativa. ${ }^{65}$

Por capacidade funcional institucional, entende o autor alemão como as condições básicas para a existência de um mecanismo eficiente dos segmentos de mercado, vale dizer, acesso o mais livre possível dos emitentes e da oferta e demanda dos investidores ["quanto maior oferta e demanda maior a capacidade de captação (liquidez)"], execução rápida de ordens para evitar grandes flutuações de preço, que os valores mobiliários tenham forma jurídica que permita uma transferência descomplicada de titularidade, busca da confiança, dever de igual tratamento, transparência da estrutura acionária, regras de conduta para os intermediários (obrigação de evitar conflitos de interesse), defesa de interesses como proteção do investidor e a fiscalização estatal do mercado. ${ }^{66}$

Já a capacidade funcional operativa consiste na manutenção dos custos de emissão - despesas decorrentes da emissão de valores mobiliários - e de compra e venda, isto é, que se mantenham os encargos financeiros nos patamares mais baixos possíveis. ${ }^{67}$

Ademais, cumpre à tutela dos mercados garantir sua capacidade funcional alocativa, em outras palavras, "deve assegurar que os escassos recursos de capitais em

\footnotetext{
${ }^{64}$ KÜMPEL, Siegfried. Op. cit., p. 22

${ }^{65}$ Op. cit., p. 22-23

${ }^{66}$ Idem, p. 24-25
} 
busca de investimentos fluam preferencialmente para onde a respectiva demanda mais urgente por meios de investimento prenuncie o maior rendimento com suficiente segurança". 68

Júlio Ramalho Dubeux propõe como interesse maior para a regulação e tutela do mercado de capitais a busca pela "eficiência na determinação do valor dos títulos negociados", "eficiência na transferência de títulos entre os participantes do mercado", "equidade nas relações do investidor com seu intermediário financeiro" e "manutenção da confiança do público investidor no Mercado de Capitais". ${ }^{69}$

Subsidiariamente à garantia do eficiente funcionamento do Mercado de Capitais, decerto, acaba-se por proteger aos interesses dos investidores, assim entendidos como o público investidor, conceito que comporta os investidores efetivos e aqueles potencialmente considerados. $^{70}$

Em suma, conclui-se que a finalidade da tutela e regulação do Mercado de Capitais é a capacidade funcional- eficiência, correto funcionamento - do mercado, o que acaba implicando em uma subsidiária proteção aos interesses do público investidor. Tal concepção será levada em consideração para a identificação do bem jurídico na esfera penal, e que será objeto de estudo no capítulo 4 da presente dissertação.

\subsubsection{Principais diplomas legais: Lei do Mercado de Capitais e Lei das Sociedades} Anônimas

Ante a necessidade de desonerar o Banco Central das funções regulatórias até então exercidas, e correspondendo a uma necessidade de regulamentação mais eficiente do Mercado de Capitais, é editada em 7 de dezembro de 1.976 a Lei 6.385/76, que dispôs sobre o Mercado de Capitais e criou a Comissão de Valores Mobiliários.

\footnotetext{
${ }^{67}$ Ibidem, p. 32-33

${ }^{68}$ Idem, p. 35

${ }^{69}$ Op. cit., p. $32-33$

${ }^{70}$ KÜMPEL, Siegfried. Op. cit., p. 36 e ss. Nesse contexto, define o autor: "Do ponto de vista do Mercado de Capitais, o termo 'público' engloba toda a oferta e demanda. Tal potencial (de compra e venda) dos investidores é de grande importância para a liquidez do mercado de capitais e, por conseguinte, para a sua capacidade. Assim, a proteção do público serve simultaneamente à capacidade funcional do mercado de capitais. Portanto, para assegurar a capacidade funcional, as regulamentações do mercado de capitais devem levar em conta uma proteção suficiente da totalidade dos investidores atuais e futuros”. (p. 37)
} 
Em linhas gerais, referido diploma delimitou quais as atividades envolvendo valores mobiliários que seriam por ela disciplinadas e fiscalizadas. Tratou de definir o conceito de valores mobiliários e delimitar as funções a serem exercidas pelo Conselho Monetário Nacional, a Comissão de Valores Mobiliários enquanto órgãos reguladores do mercado de capitais, além de dispor acerca do funcionamento do mercado como um todo.

Problemática das mais recentes no âmbito do direito do Mercado de Capitais consiste na conceituação precisa do que vem a ser valor mobiliário. Tal conceituação tem reflexos diretos na esfera criminal, uma vez que se trata de elemento integrador da norma penal.

No Brasil, até meados da década de 1.970, inexistia qualquer conceito do que seriam valores mobiliários. Foi justamente com a reforma do Mercado de Capitais, até então muito incipiente no país, que se deu o primeiro passo no sentido de conceituação, por meio da norma criadora da Comissão de Valores Mobiliários, a CVM.

$\mathrm{O}$ art. $2^{\circ}$, da Lei $6.385 / 76$, em sua redação original, estabelecia três categorias de valores mobiliários, a saber: (i) valores mobiliários societários emitidos pelas sociedades por ações e seus certificados de depósito; (ii) demais valores mobiliários emitidos pelas sociedades anônimas que fossem considerados como tal pelo Conselho Monetário Nacional; e (iii) valores mobiliários excluídos expressamente da competência regulatória da CVM, incluindo-se nestes últimos títulos representativos da dívida pública e aqueles emitidos por instituições financeiras.

No entender de José Eduardo Carneiro Queiroz:

[...] a metodologia do legislador era a de tentar estabelecer uma lista exaustiva de ativos que abrangesse as diversas operações praticadas no Mercado de Capitais, sem efetivamente apontar para quais os requisitos que deveriam estar presentes na caracterização de valor mobiliário. ${ }^{71}$

${ }^{71}$ O Conceito de Valor Mobiliário e a competência da Comissão de Valores Mobiliários e do Banco Central do Brasil. Aspectos atuais do Direito do Mercado Financeiro e de Capitais. Coord. Roberto Quiroga Mosquera. São Paulo: Dialética, 1999, p. 133 
Tratou o legislador, com a edição da norma em comento, pois, apenas de delimitar a competência da CVM. Contudo, parte relevante do Mercado de Capitais, como fundos de investimento de renda fixa e derivativos ficou excluída da competência reguladora da CVM, cabendo ao Banco Central esse papel. Vigorava, pois, nos dizeres de Jean Paul C. Veiga da Rocha, "um sistema exclusivamente de lista", desprovido de conceituação precisa. ${ }^{72}$

Em 1.998, no curso das recentes reformas na legislação de Mercado de Capitais, iniciadas em 1.997, deu-se, com a edição da Medida Provisória $n^{\circ}$ 1.637/98, significativa alteração no texto do art. $2^{\circ}$, da Lei 6.385/76.

Mencionado dispositivo passou a incluir o conceito de contrato de investimento na definição de valor mobiliário. O termo contrato de investimento, consoante aponta José Eduardo Carneiro Queiroz ${ }^{73}$, surgiu nos EUA, no ano de 1.946, em discussão judicial acerca da competência da SEC - Securities and Exchange Commission, órgão responsável pela regulação do Mercado de Capitais norte-americano. ${ }^{74}$

Segundo o autor, o entendimento acerca de contrato de investimento passa por quatro características fundamentais: “(i) investimento de dinheiro; (ii) empreendimento comum; (iii) expectativa de lucro; e (iv) gestão do empreendedor ou de terceiros." ${ }^{75}$ Desta feita, entendeu a Suprema Corte dos EUA que quando presentes tais características em contratos e títulos ofertados ao público, resta identificado um valor mobiliário, e em tais operações deve prevalecer o poder regulatório da SEC - Securities and Exchange Commission.

Às características acima apontadas, deverão ser agregadas duas outras, consoante entendimento de Jean Paul C. Veiga da Rocha: (i) o risco do investimento; e, (ii) a passividade do investidor. ${ }^{76}$

\footnotetext{
${ }^{72}$ As consequiências institucionais do novo conceito de Valor Mobiliário: as competências do CMN, do Bacen e da CVM. Aspectos atuais do Direito do Mercado Financeiro e de Capitais, $2^{\circ}$ volume. Coord. Roberto Quiroga Mosquera. São Paulo: Dialética, 2000, p. 71

${ }^{73}$ Op. cit., p. 134

${ }^{74}$ SEC vs. W. J. Howey Co.

${ }^{75}$ Idem

${ }^{76}$ Op. cit., p. 77
} 
Com essa recente ampliação do conceito de valor mobiliário, houve, por conseqüência, um alargamento no tocante à competência da CVM, incluindo operações antes reguladas pelo Banco Central, e outras sem qualquer tipo de regulação anterior. ${ }^{77}$

Segundo dispõe a Lei 6.385/76, em seu art. $2^{\circ}$, com a redação dada pela Lei 10.303/2001, são considerados valores mobiliários:

i) as ações, debêntures e bônus de subscrição;

ii) os cupons, direitos, recibos de subscrição e certificados de desdobramento relativos aos valores mobiliários referidos no inciso II;

iii) os certificados de depósito de valores mobiliários;

iv) as cédulas de debêntures;

v) as cotas de fundos de investimento em valores mobiliários ou de clubes de investimento em quaisquer ativos;

vi) as notas comerciais;

vii) os contratos futuros, de opções e outros derivativos, cujos ativos subjacentes sejam valores mobiliários;

viii) outros contratos derivativos, independentemente dos ativos subjacentes; e

ix) quando ofertados publicamente, quaisquer outros títulos ou contratos de investimento coletivo, que gerem direito de participação, de parceria ou de remuneração, inclusive resultante de prestação de serviços, cujos rendimentos advêm do esforço do empreendedor ou de terceiros.

Ficam excluídos do rol do citado dispositivo os títulos da dívida pública federal, estadual ou municipal e os títulos cambiais de responsabilidade de instituição financeira, exceto as debêntures. ${ }^{78}$

Tais definições são imprescindíveis à análise da tutela penal do Mercado de Capitais, posto que integradoras dos tipos penais presentes na Lei 6.385/76, consoante se verificará ao longo do presente estudo.

${ }^{77}$ Como exemplo, os contratos futuros de "boi gordo", que passaram a ser negociados na BM\&F - Bolsa de Mercadorias e Futuros, e objeto de grande controvérsia jurídica, com implicações na esfera penal, em um passado recente.

${ }^{78}$ Lei 6.385/76, art. $2^{\circ}$, parágrafo $1^{\circ}$, conforme redação dada pela Lei 10.303/2001 
Outro ponto de destaque no tocante à Lei do Mercado de Capitais reside na expressa previsão de garantia do princípio de disclosure, competindo à CVM assegurar o acesso do público às informações sobre os valores mobiliários negociados, bem como sobre as companhias emissoras. Nesse contexto, determina a lei que a CVM deverá expedir normas acerca das informações que as companhias deverão divulgar, bem como sua periodicidade. $^{79}$

A reforma legislativa relevante mais recente do Mercado de Capitais, iniciada em 2.001, com a edição de Lei 10.303, teve, ainda, como consequências a serem destacadas para fins do presente estudo, dois pontos essenciais.

Em primeiro lugar, houve um fortalecimento dos poderes regulatórios da CVM, na medida em que lhe foi concedida personalidade jurídica e patrimônio próprios, com autonomia financeira e orçamentária; autoridade administrativa independente; autonomia política, por meio da estabilidade de seus dirigentes; e ausência de subordinação hierárquica, ainda que permaneça vinculada ao Ministério da Fazenda. ${ }^{80}$

Tal autonomia à Comissão de Valores Mobiliários decorreu, segundo apontam Modesto Carvalhosa e Nelson Eizirik, de dois fatores distintos: uma real necessidade de independência financeira, e uma tendência internacional pela criação de agências reguladoras independentes, nos moldes do modelo norte-americano. ${ }^{81}$

Outro marco da reforma do mercado de capitais ocorrida em 2.001, foi a inserção na Lei 6.385/76 do Capítulo VII-B, que passou a disciplinar os crimes contra o Mercado de Capitais, tornando ilícitos penais condutas que, via de regra, até então eram consideradas tão somente ilícitos administrativos.

Nesse compasso, foram criados os tipos penais de manipulação de mercado (art. 27-C), ${ }^{82}$ uso indevido de informação privilegiada (art. 27-D) ${ }^{83}$ e exercício irregular de

\footnotetext{
${ }^{79}$ Artigos $4^{\circ}$, VI e $22, \S 1^{\circ}$, da Lei $6.385 / 76$

${ }^{80}$ CARVALHOSA, Modesto; EIZIRIK, Nelson. Op. cit., p. 432 e ss.

${ }^{81}$ Idem, p.437

82 “Art. 27-C. Realizar operações simuladas ou executar outras manobras fraudulentas, com a finalidade de alterar artificialmente o regular funcionamento dos mercados de valores mobiliários em bolsa de valores, de mercadorias e de futuros, no mercado de balcão ou no mercado de balcão organizado, com o fim de obter
} 
cargo, profissão, atividade ou função (art. 27-E), ${ }^{84}$ sendo que os dois primeiros serão objeto de análise detalhada em momento posterior da presente dissertação.

No tocante à Lei das Sociedades Anônimas (Lei 6.404/76), esta trata de disciplinar as atividades dos principais atores do mercado de capitais, as companhias abertas, ou sociedades anônimas. São elas as principais tomadoras de financiamentos diretos no Mercado de Capitais, por meio da oferta de ações e outros valores mobiliários ao mercado.

São, portanto, figuras de extrema relevância para a garantia de estabilidade do Mercado de Capitais como um todo.

José Edwaldo Tavares Borba preceitua que a Lei 6.404/76 apresenta cinco linhas básicas de orientação:

$1^{\text {a) }}$ a da proteção aos acionistas minoritários; $2^{\mathrm{a}}$ ) a da responsabilização do acionista controlador; $3^{\circ}$ ) da ampla diversificação dos instrumentos postos na Lei, à disposição dos acionistas, para serem, ou não adotados pela sociedade; $4^{a}$ ) da diferenciação entre companhia aberta e fechada; $5^{\mathrm{a}}$ ) a da definição dos interesses fundamentais que a sociedade anônima representa $\left[\ldots . . .{ }^{85}\right.$

Segue o autor, ao analisar o parágrafo único do artigo 116 do referido diploma, que trata dos deveres e responsabilidades do acionista controlador, para apontar a definição dos interesses fundamentais das sociedades anônimas:

A sociedade anônima deixa de ser um mero instrumento de produção de lucros para distribuição aos detentores do capital, para elevar-se à condição de instituição destinada a exercer o seu objeto para atender aos interesses de acionistas, empregados e comunidade. Esses três interesses

vantagem indevida ou lucro, para si ou para outrem, ou causar dano a terceiros: Pena - reclusão, de 1 (um) a 8 (oito) anos, e multa de até 3 (três) vezes o montante da vantagem ilícita obtida em decorrência do crime.”

83 “Art. 27-D. Utilizar informação relevante ainda não divulgada ao mercado, de que tenha conhecimento e da qual deva manter sigilo, capaz de propiciar, para si ou para outrem, vantagem indevida, mediante negociação, em nome próprio ou de terceiro, com valores mobiliários: Pena - reclusão, de 1 (um) a 5 (cinco) anos, e multa de até 3 (três) vezes o montante da vantagem ilícita obtida em decorrência do crime."

84 “Art. 27-E. Atuar, ainda que a título gratuito, no mercado de valores mobiliários, como instituição integrante do sistema de distribuição, administrador de carteira coletiva ou individual, agente autônomo de investimento, auditor independente, analista de valores mobiliários, agente fiduciário ou exercer qualquer cargo, profissão, atividade ou função, sem estar, para esse fim, autorizado ou registrado junto à autoridade administrativa competente, quando exigido por lei ou regulamento: Pena - detenção de 6 (seis) meses a 2 (dois) anos, e multa."

${ }^{85}$ Direito Societário. Rio de Janeiro: Renovar, 2003, p. 133 
devem, por conseguinte, conviver equilibradamente no âmbito da sociedade; as decisões tomadas terão, necessariamente, que considerálos, a fim de que nenhum deles seja sacrificado. ${ }^{86}$

Nota-se, de pronto, que a Lei das Sociedades Anônimas tratou de estabelecer interesses fundamentais que devem ser atendidos por seus controladores e administradores, interesses esses que, certamente, compõe o conceito de estabilidade do Mercado de Capitais que, consoante se verificará, vem a ser o fundamento para uma regulação em sentido amplo do mercado.

Referido diploma legal elenca uma série de direitos dos acionistas que, por consequência, se configuram em deveres aos administradores das companhias emissoras, com especial ênfase, para fins do presente trabalho, ao dever de informar, previsto nos artigos 157 e 175 a 188; e que nada mais são do que a materialização do princípio de disclosure estudado anteriormente ${ }^{87}$.

\subsubsection{Do controle administrativo}

A estrutura regulatória do Mercado de Capitais é constituída basicamente pelo Conselho Monetário Nacional (CMN) e pela Comissão de Valores Mobiliários $(\mathrm{CVM})$, competindo papel auxiliar às bolsas de valores e entidades do mercado de balcão.

Dentro desse contexto, o Conselho Monetário Nacional-CMN é a mais alta instância do Sistema Financeiro Nacional, e órgão responsável pela edição de normas regulamentares orientadoras do mercado financeiro e de capitais. É composto pelo ministro da Fazenda, que o preside, ministro do Planejamento, Orçamento e Gestão e pelo presidente do Banco Central. Ao CMN também está vinculado o Conselho de Recursos do Sistema Financeiro Nacional, também chamado de "conselhinho", entidade competente para julgar, em última instância, as decisões proferidas pela CVM em processos administrativos.

\footnotetext{
${ }^{86}$ Idem, p. 134

${ }^{87}$ DUBEUX, Júlio Ramalho. Op. cit., p. 44. Acerca do tema, vide também: BORBA, José Edwaldo Tavares. Op. cit., p. 420-423
} 
Abaixo do CMN está a Comissão de Valores Mobiliários, órgão responsável pela regulação direta do Mercado de Capitais. Fiscaliza não apenas as atividades de intermediação de sua competência; como também a atividade das bolsas de valores e outros agentes do mercado secundário, os quais, por sua vez, funcionam como órgãos auxiliares do Sistema Financeiro Nacional.

\subsubsection{A Comissão de Valores Mobiliários: CVM}

Criada pela Lei 6.385/76, passa a atuar como órgão regulador do Mercado de Capitais brasileiro ${ }^{88}$. Sua origem teve clara influência do modelo regulatório norteamericano, tratando-se, consoante afirmado por Júlio Ramalho Dubeux, de verdadeiro caso de recepção de um modelo estrangeiro pelo sistema brasileiro ${ }^{89}$. Tal qual a Securities and Exchange Commission (SEC), a CVM é um órgão federal regulador com poderes híbridos (normativos, executivos e judicantes), dirigida por um colegiado composto por cinco membros. Ademais, consoante afirma o autor, tal qual no modelo adotado nos Estados Unidos, convive a CVM com a auto-regulação das bolsas de valores, as quais, a despeito de sua natureza privada, são sujeitas à supervisão do órgão. ${ }^{90}$

Todavia, enquanto o órgão norte-americano foi criado para coibir práticas inadequadas em um mercado já estabelecido, no Brasil, a criação da CVM se deu para fins de desenvolvimento de um mercado até então incipiente.

A principal característica do órgão regulador em seus moldes atuais consiste em sua independência, plenamente alcançada somente com a reforma do Mercado de Capitais ocorrida em 2.001. Nos termos do artigo $5^{\circ}$, da Lei do Mercado de Capitais, com sua atual redação, consiste a CVM em uma autarquia federal, "vinculada ao Ministério da Fazenda, com personalidade jurídica e patrimônio próprios, dotada de autoridade administrativa independente, ausência de subordinação hierárquica, mandato fixo e estabilidade de seus dirigentes, e autonomia financeira e orçamentária."

\footnotetext{
${ }^{88}$ Desde a criação do Conselho Monetário Nacional, até a edição da Lei do Mercado de Capitais, era o Banco Central do Brasil o órgão regulador do Mercado de Capitais em nosso país, por força da Lei 4.728/65.

${ }^{89}$ Op. cit., p. 38

${ }^{90}$ Idem, p. 42
} 
Em razão da independência conferida pela Lei, a CVM assumiu, definitivamente, o formato de verdadeira entidade reguladora, conforme aponta Júlio Ramalho Dubeux:

[...] a independência dos dirigentes também tem significativa importância no sentido de barrar eventuais pressões dos setores econômicos regulados, cujos atores muitas vezes são hábeis em pressionar o Poder Executivo com vistas à troca de dirigentes das autarquias, especialmente quando vêem seus interesses serem contrariados. A independência conferida aos dirigentes, por conseguinte, aponta para ambos os sentidos, seja em relação ao Poder Executivo, seja em relação aos administrados regulados. ${ }^{91}$

Resta claro, pois, que a CVM, enquanto órgão federal independente, exerce papel fundamental na regulação do Mercado de Capitais, tendo, dentre suas principais funções, em primeiro plano, a edição de normas gerais que possibilitem o eficiente funcionamento do mercado.

Tal atribuição de cunho normativo consiste na expedição de atos como instruções, deliberações, pareceres e notas explicativas, por meio das quais a CVM leva a cabo as diretrizes definidas pelo $\mathrm{CMN}$, com especial atenção para as instruções, que têm como objeto a regulamentação das matérias expressamente previstas nas leis do Mercado de Capitais e das sociedades por ações, com destaque para as instruções que regulam o registro das companhias abertas e o registro de oferta pública de distribuição de valores mobiliários, os quais, segundo aponta Júlio Ramalho Dubeux, "são o principal instrumento de concretização da política de divulgação de informações (disclosure)", em outras palavras, a CVM estabelece, por meio da normatização dos registros, basicamente, os deveres jurídicos de prestação de informações pelas companhias emissoras. ${ }^{92}$

Mas estes não são os únicos objetos de normatização pela CVM, que também se preocupa em regulamentar, dentre outros assuntos, os registros e as condutas dos intermediários do mercado, a constituição e o funcionamento das entidades autoreguladoras, a tipificação das operações fraudulentas, as práticas manipulatórias, a criação

${ }^{91}$ Op. cit., p. 36 . No mesmo sentido: KÜMPEL Siegfried. Op. cit., p. 14-15
${ }_{92}$ Op. cit., p. 51 
de condições artificiais de mercado, as práticas não equitativas e as atividades de auditoria independente. ${ }^{93}$

Dentre as instruções normativas editadas pela CVM, verifica-se, como exemplo, a Instrução 358/02, que dispõe sobre o uso de informações na negociação com valores mobiliários e define o que vem a ser ato ou fato relevante. Trata-se aqui de matéria intimamente ligada à tipificação do crime de uso indevido de informação privilegiada, que será objeto de estudo detalhado no capítulo 4 da presente dissertação.

Outra função essencial da CVM consiste na execução dos instrumentos e mecanismos que visam ao cumprimento das normas do Mercado de Capitais por parte dos participantes deste mercado. Nesse contexto, cabe ao órgão regulador, em primeiro plano, o exercício da atividade fiscalizadora sobre os participantes do mercado, dentre os quais, destacam-se: instituições financeiras de distribuição de valores mobiliários, companhias emissoras, mediadores de negociação de valores em bolsa ou mercado de balcão, bolsas de valores, entidades de mercado de balcão, corretoras, operadores e bolsas de mercadorias e futuros, entidades de compensação e liquidação de operações e quaisquer outras pessoas que tenham atuado no Mercado de Capitais, bem como controladores e empresas coligadas de companhias emissoras e fundos de investimento.

Dentre tais atividades, destaca-se o poder legal para examinar e extrair cópias de demonstrações e registros contábeis, livros, documentos, programas eletrônicos, arquivos magnéticos, ópticos e de qualquer outra natureza, dos participantes do mercado mencionados no parágrafo anterior. ${ }^{94}$

Mas o poder de fiscalização da CVM não se restringe ao exame de documentos, sendo franqueado à autarquia expedir intimações a fim de convocar pessoas para prestação de informações ou esclarecimentos, ${ }^{95}$ bem como requisitar informações de órgãos públicos. ${ }^{96}$

\footnotetext{
${ }^{93}$ Idem, p. 72

${ }^{94}$ Artigo, $9^{\circ}$, I, da Lei 6.385/76

${ }^{95}$ Artigo $9^{\circ}$, II, da Lei 6.385/76

${ }^{96}$ Artigo $9^{\circ}$, III, da Lei 6.385/76
} 
Pode a CVM ainda determinar a republicação com correções ou aditamentos de demonstrações financeiras, relatórios ou informações já divulgadas, ${ }^{97}$ e divulgar informações ou recomendações a fim de, preventivamente, esclarecer e orientar os participantes do mercado quanto ao cumprimento de determinada norma. ${ }^{98}$

A atuação preventiva da CVM alcança também a faculdade de proibir atos e práticas que sejam, a seu juízo, prejudiciais ao correto funcionamento do mercado ${ }^{99}$, bem como suspender a negociação de determinado valor mobiliário, decretar o recesso das bolsas de valores e proceder ao cancelamento de registros. ${ }^{100}$ Quanto a este aspecto, não obstante a intervenção do órgão regulador nos negócios privados seja apenas a última instância de atuação da autarquia, quanto ao cancelamento de registros, esta faculdade tem especial importância nos chamados processos de 'abertura de capital'; o que se justifica ante a ausência de histórico dos fundadores ou da nova companhia a ingressar no mercado de capitais. ${ }^{101}$

Cabe à CVM outrossim, a possibilidade de firmar convênios com entidades nacionais e internacionais, para cooperação ao combate de ilícitos no âmbito do Mercado de Capitais, a fim de facilitar e agilizar o fluxo de informações. ${ }^{102}$ Quanto ao assunto, merece destaque o convênio firmado entre CVM e Ministério Público Federal, em 08 de maio de 2.008, pelo qual o órgão regulador e a instituição se comprometem a estreitar relacionamento, propiciando maior "agilidade e efetividade nas relações de prevenção, apuração e repressão às práticas lesivas ao mercado de capitais". Por força deste convênio, fica estabelecido o compromisso de intercâmbio de informações, ampla cooperação técnica e científica, o desenvolvimento e aprimoramento de técnicas e procedimentos empregados na apuração, prevenção e repressão de práticas lesivas ao mercado e, especialmente, a comunicação da CVM ao Ministério Público Federal "para adoção das medidas legais cabíveis em defesa dos interesses do mercado de valores mobiliários e dos seus respectivos investidores, nas esferas administrativa, civil ou criminal". ${ }^{103}$ Quanto ao dever de informar

\footnotetext{
${ }^{97}$ Artigo $9^{\circ}$, IV, da Lei 6.385/76

${ }^{98}$ Artigo $9^{\circ}, \S 1^{\circ}$, III, da Lei $6.385 / 76$

${ }^{99}$ Artigo $9^{\circ}, \S 1^{\circ}$, IV, da Lei $6.385 / 76$

${ }^{100}$ Artigo $9^{\circ}, \S 1^{\circ}$, I e II, da Lei 6.385/76

${ }^{101}$ DUBEUX, Júlio Ramalho. Op. cit., p. 70

${ }^{102}$ Para maiores informações, vide: http://www.cvm.gov.br/

${ }^{103}$ Cumpre destacar, também, que por força do disposto no artigo $1^{\circ}$ da Lei 7.913/89, a CVM pode provocar a atuação do Ministério Público no tocante ao ajuizamento de ações civis públicas, quando se tratar da defesa de interesses coletivos.
} 
ao Ministério Público acerca da ocorrência, em tese, de crime contra o mercado de capitais, este decorre expressamente de Lei, sendo obrigação do órgão regulador, ao final do inquérito administrativo, verificada a hipótese de ocorrência de ilícito penal, oficiar ao órgão ministerial para adoção das medidas cabíveis. ${ }^{104}$

Outra das funções executivas da CVM consiste no poder de adiamento e interrupção de assembléia geral de companhias abertas, quando o objeto de tais assembléias for considerado complexo, demandando análises mais completas, como nos casos de fusões, cisões, incorporações, aquisição de outras companhias ou alterações estatutárias. Trata-se, consoante observa Júlio Ramalho Dubeux, de instrumento voltado à proteção dos acionistas minoritários. ${ }^{105}$

Por fim, exerce a CVM função judicante, vale dizer, é o órgão responsável pela condução dos processos administrativos sancionadores e, consequentemente, pela aplicação das sanções administrativas cominadas, ponto que será tratado com maior detalhamento no apartado subsequente.

Não se pode negar, pois, a importância da CVM dentro do sistema regulatório do Mercado de Capitais brasileiro, tanto como órgão aplicador das diretrizes gerais definidas pelo Conselho Monetário Nacional, como na qualidade de órgão independente e altamente especializado, responsável pela fiscalização direta dos atores do Mercado de Capitais e, consequentemente, pela aplicação das sanções administrativas cominadas em Lei.

\subsubsection{Processo administrativo}

Como decorrência da atividade fiscalizadora da CVM, compete a este órgão a possibilidade de aplicação das sanções decorrentes do descumprimento das normas regulamentares do Mercado de Capitais. Tal autorização está expressa na Lei 6.385/76, que dispõe expressamente acerca das penalidades administrativas aplicáveis que são, advertência; multa; suspensão ou inabilitação temporária do exercício do cargo de

\footnotetext{
${ }^{104}$ Artigo 12 da Lei 6.385/76: "Quando o inquérito, instaurado de acordo com o $\$ 2^{\circ}$ do art. $9^{\circ}$, concluir pela ocorrência de crime de ação pública, a Comissão de Valores Mobiliários oficiará ao Ministério Público, para a propositura da ação penal."
} 
administrador ou de conselheiro fiscal de companhia aberta, de entidade do sistema de distribuição ou de outras entidades que dependam de autorização ou registro na Comissão de Valores Mobiliários; suspensão ou cassação da autorização ou registro para o exercício das atividades de que trata a Lei 6.385/76; proibição temporária de praticar determinadas atividades ou operações, para os integrantes do sistema de distribuição ou de outras entidades que dependam de autorização ou registro na Comissão de Valores Mobiliários; e proibição temporária de atuar, direta ou indiretamente, em uma ou mais modalidades de operação no mercado de valores mobiliários. ${ }^{106}$

A aplicação da pena de advertência se dá nos casos considerados pelo órgão regulador como mais leves,ou para infratores que não sejam reincidentes, porém, consoante observa Nelson Eizirik, "embora constitua uma sanção branda, importa inequivocamente em penalidade administrativa". ${ }^{107}$

A sanção pecuniária, por sua vez, pode ser aplicada aos casos em todos os níveis de gravidade (leve, moderada e grave) de infrações, devendo, contudo, observar os limites máximos estabelecidos pela Lei 6.385/76, consubstanciados em: quinhentos mil reais; cinqüenta por cento do valor da emissão ou operação irregular; três vezes o montante da vantagem econômica obtida ou da perda evitada em decorrência do ilícito.

Já as sanções restritivas ou impeditivas do exercício de atividade ou participação no Mercado de Capitais são aplicadas às infrações de natureza grave, ainda que, consoante observa Fábio Medina Osório, ausente qualquer definição legal acerca dos graus de gravidade das infrações administrativas, ${ }^{108}$ havendo, pois, grande campo de discricionariedade aos julgadores da CVM para aplicação das sanções administrativas.

\footnotetext{
105 Op. cit., p. 80-88

${ }^{106}$ Artigo 11 e incisos da Lei 6.385/76

${ }^{107}$ Reforma das S/A e do mercado de capitais. $2^{\mathrm{a}}$ ed. Rio de Janeiro: Renovar, 1998, p. 227

108 Devido processo administrativo sancionador no sistema financeiro nacional. Direito administrativo sancionador: sistema financeiro nacional. Coord. Fábio Medina Osório. Belo Horizonte: Fórum, 2007, p. 13- 
A Lei não veda a cumulação de sanções, não sendo raro, em casos considerados muito graves pelo órgão regulador, a aplicação de pena de multa cumulada com uma sanção de natureza restritiva de direitos. ${ }^{109}$

Cumpre, todavia, destacar que a aplicação de qualquer sanção administrativa por parte da CVM deve, obrigatoriamente, obedecer a um critério de proporcionalidade, devendo ainda as decisões serem devidamente fundamentadas, tratando-se da aplicação de dois importantes princípios informadores do processo administrativo sancionador.

O processo administrativo sancionador da CVM é regulado pelas resoluções 454/77 e 1.657/89 do CMN, pela Deliberação CVM 457/02 e pela Instrução CVM 251/96, aplicando-se, subsidiariamente a Lei 9.784/99 (Lei do Processo Administrativo), e pode seguir o rito ordinário ou sumário.

O rito ordinário é disciplinado pela Resolução CMN 454/77 e pela Deliberação CVM 457/02, e estipula a existência de uma peça acusatória, elaborada pelas áreas técnicas da CVM, denominada termo de acusação, a qual deverá constar a qualificação completa dos acusados, a narrativa dos fatos, os elementos de autoria e materialidade e o enquadramento legal ou normativo das infrações. Apresentado o termo de acusação, os acusados serão intimados para apresentação de defesa escrita no prazo de trinta dias, e em seguida o processo será levado ao Colegiado para julgamento, sendo distribuído a um relator, a quem caberá o deferimento ou indeferimento de provas ou a determinação de novas diligências. Ao final da instrução o relator levará o processo a julgamento, que ocorrerá em sessão pública, com a possibilidade de sustentação oral aos acusados. Havendo empate no julgamento, caberá ao presidente da CVM o voto de desempate, e a decisão administrativa deverá conter um relatório do processo, os fundamentos da decisão e uma parte dispositiva, nos mesmos moldes de uma decisão judicial. Das decisões proferidas pelo Colegiado nos processos de rito ordinário, caberá

\footnotetext{
${ }^{109}$ Segundo aponta Júlio Ramalho Dubeux: “[...] a não fixação de específica sanção para cada infração segue uma lógica certa, qual seja a de conferir maior flexibilidade à entidade reguladora, o que coincide com a própria natureza do processo administrativo, marcantemente menos rígido do que o processo penal ou o processo civil. Nesse sentido, acreditamos que a possibilidade de cumulação de sanções ajuda a CVM a encontrar a penalidade correta para a boa regulação do mercado". (Op. cit., p. 95)
} 
recurso, em segunda e última instância, ao Conselho de Recursos do Sistema Financeiro Nacional.

O rito sumário, por sua vez, está regulado pela Resolução CMN 1.657/89 e pela instrução CVM 251/96, e tem aplicação para os casos expressamente previstos na referida instrução da CVM, aos quais é cominada exclusivamente pena de multa. Diferencia-se do rito ordinário no tocante ao prazo para apresentação de defesa, que será de dez dias, e será julgado pela própria Superintendência técnica responsável pela apresentação do termo de acusação. Da decisão proferida pela Superintendência Técnica, caberá recurso ao Colegiado da CVM, que atuará como última instância de julgamento.

Nos casos de absolvição, a CVM interpõe recurso de ofício ao Conselho de Recursos do Sistema Financeiro Nacional.

Caso necessário, a depender da complexidade dos casos, o processo administrativo pode ser precedido de uma etapa investigativa, com a instauração de inquérito administrativo - procedimento inquisitorial com vistas a reunir elementos necessários à averiguação da prática ilícita e sua autoria - que será conduzido por uma Comissão de Inquérito designada pelo Colegiado da CVM.

Importante se ter em conta que os processos administrativos da CVM estão necessariamente vinculados à aplicação dos princípios informadores do processo administrativo sancionador, decorrentes das garantias firmadas no artigo $5^{\circ}$ da Constituição Federal, e contemplados pela Lei 9.784/99, especialmente quanto à observância do devido processo legal, legalidade, finalidade, obrigatoriedade de motivação das decisões, proporcionalidade, moralidade, segurança jurídica e publicidade dos atos. ${ }^{110}$

Outro instrumento de suma relevância no exercício das funções judicantes da CVM constitui o chamado termo de compromisso. Incorporado à Lei 6.385/76 ${ }^{111}$ pela reforma de 1.997, e regulado administrativamente pela CVM por meio das deliberações 390/01 e 486/05, é aplicável tanto quando da existência de inquérito administrativo como de processo sancionador.

\footnotetext{
${ }^{110}$ OSÓRIO, Fábio Medina. Op. cit., p. 17 e ss.; DUBEUX, Júlio Ramalho. Op. cit., p. 91

${ }^{111}$ Artigo $11, \S \S 5^{\circ}$ a $8^{\circ}$, da Lei $6.385 / 76$
} 
Em linhas gerais, constitui faculdade conferida aos investigados ou acusados, para oferecer uma proposta de termo de compromisso ao órgão regulador, a qual deverá conter dois requisitos obrigatórios: a cessação da prática de atividades consideradas lesivas ao mercado; e a correção das atividades consideradas lesivas ao mercado de capitais, com a indenização dos prejuízos causados aos investidores ou à própria autarquia.

Referido termo não importa, contudo, confissão ou reconhecimento de práticas ilegais pelo proponente. Apresentado o termo de compromisso, este será analisado, mediante parecer, pela Procuradoria Federal especializada da CVM, e pelo Comitê de Termo de Compromisso, formado pelas diversas superintendências técnicas do órgão regulador, que recomendará ao Colegiado - responsável pela decisão quanto à aceitação do termo de compromisso - a sua aceitação ou não, de acordo com um juízo de oportunidade e conveniência.

A criação de tal comitê, decorrente da Deliberação CVM 486/05, representou importante alteração na forma procedimental, pois, consoante apontado por Ricardo Villas Bôas Cueva, ${ }^{112}$ configurou uma forma de autolimitação ao poder discricionário do Colegiado, que anteriormente deliberava pela aceitação do termo de compromisso sem qualquer respaldo técnico prévio.

Vistos os principais instrumentos ao exercício da função judicante da CVM, importa verificar que, na prática, o órgão regulador vem obtendo grande sucesso na repressão e prevenção a ilícitos praticados contra o Mercado de Capitais, muito por conta da ampla utilização do termo de compromisso ${ }^{113}$ e pela aplicação de sanções pesadas em termos pecuniários e de restrição ou proibição do exercício de atividades junto ao Mercado de Capitais, especialmente nos casos de uso indevido de informação privilegiada.

\footnotetext{
112 “A autolimitação de sua discricionariedade, pela CVM, mediante a criação do comitê de termo de compromisso, tende inegavelmente a aumentar a transparência do procedimento, bem como a definir critérios objetivos para celebração do compromisso". (Termo de compromisso no processo administrativo sancionador do Banco Central: possibilidades e limites. In: Direito administrativo sancionador: sistema financeiro nacional. Coord. Fábio Medina Osório. Belo Horizonte: Fórum, 2007, p.300)

113 "Esse notável sucesso pode também ser atribuído à flexibilidade com que têm sido moldados os termos de compromisso celebrados pela CVM, cujas cláusulas, em muitos casos, não se limitam à cessação da prática, à correção das irregularidades ou à indenização dos danos por elas causados, mas visam também à prevenção das irregularidades e à reparação às lesões aos direitos difusos ou coletivos envolvidos”. (Idem, p. 301)
} 


\subsection{A dúvida da necessidade de controle penal}

Com a exacerbação da dogmática e da política criminal academicista, até meados dos anos 60, o direito penal acabou por se isolar, fechando-se em si próprio e afastando-se da realidade à qual era aplicado. Como reação a isso, surgiu na doutrina, por volta do início da década de 1.970, um movimento no sentido de reaproximar o direito penal da realidade. ${ }^{114}$ A sugestão mais importante foi aquela formulada por Claus Roxin, que propôs o preenchimento dos conceitos da dogmática penal (tipicidade, antijuridicidade, culpabilidade, dentre outros) com conteúdos da política criminal. ${ }^{115}$

Essas ideias foram e ainda têm sido objeto de diversas discussões doutrinárias. Muitos doutrinadores não admitem o uso da política criminal como horizonte teleológico do direito penal (isto é, a funcionalização de conceitos penais a partir da política criminal), em razão de sua amplitude e das vicissitudes a que está sujeita. ${ }^{116}$ Todavia, não se pode mais admitir que o direito penal permaneça alheio à realidade, a seus efeitos e consequências.

Não se pode deixar de mencionar, aqui, o enorme impulso dado pela criminologia crítica a tais idéias, sobretudo a partir dos estudos sobre o impacto do sistema penal na realidade, podendo-se citar as teorias do labelling approach, ${ }^{117}$ a revelação das funções latentes e manifestas do sistema penal (Merton) e as idéias sobre vitimização secundária. ${ }^{118}$

\footnotetext{
${ }^{114}$ HASSEMER, Winfried. História das idéias penais na Alemanha do Pós-Guerra. Revista Brasileira de Ciências Criminais, São Paulo, v. 2, n. 6, p. 36-69, abr./jun. 1994.

115 "Parto da idéia de que todas as categorias do sistema do direito penal se baseiam em princípios reitores normativos político-criminais, que, entretanto, não contêm ainda a solução para os problemas concretos; estes princípios serão, porém, aplicados à 'matéria jurídica', aos dados empíricos, e com isso chegarão a conclusões diferenciadas e adequadas à realidade". Segundo o renomado professor, "estruturar categorias basilares do direito penal com base em pontos de vista político-criminais permite transformar não só postulados sócio-políticos, mas também dados empíricos e, especialmente, criminológicos, em elementos fecundos para a dogmática jurídica". (ROXIN, Claus. Estudos de Direito Penal; trad. Luís Greco. Rio de Janeiro: Renovar, 2006, p. 61-77)

${ }_{116}$ Acerca do tema vide: ROXIN, Claus. Estudos de Direito Penal. Op. cit., p. 64

${ }^{117}$ SHECAIRA, Sérgio Salomão. Criminologia. São Paulo: Revista dos Tribunais, 2004, p. 287 e ss.

118 "Dentre as contribuições da criminologia crítica está o fato de que o fundamento mais geral do ato desviado deve ser investigado junto às bases estruturais econômicas e sociais que caracterizam a sociedade na qual vive o autor do delito. A proposta desta teoria para o processo criminalizador objetiva reduzir as desigualdades de classe e sociais: o Estado deve assumir uma criminalização e penalização da criminalidade econômica e política, práticas anti-sociais na área de segurança do trabalho, da saúde pública, do meio ambiente, da economia popular, do patrimônio coletivo estatal e contra o crime organizado, com uma maximização da intervenção punitiva; de outro lado, há de fazer uma minimização da intervenção punitiva
} 
Considerações sobre a aptidão do direito penal para lidar com determinados problemas, bem como sobre as consequências do uso do direito penal em certos âmbitos têm, portanto, de integrar preocupações da própria dogmática penal.

Assim, a doutrina penal, mais recentemente, vem elaborando critérios para inserção, no sistema dogmático-penal, de tais preocupações. Nesse sentido, deve-se citar a proposta de Manuel da Costa Andrade, que sugere o uso dos conceitos de dignidade penal e de carência de tutela penal como referências teleológicas para a dogmática penal. ${ }^{119}$

Em resumo, o direito penal deve levar em consideração - mormente quando da decisão acerca da criminalização de determinados comportamentos - além da dignidade do valor a ser tutelado, já que somente se legitima quando voltado à proteção dos valores mais relevantes em uma determinada sociedade, também sua necessidade e aptidão.

Deve-se responder, portanto, às seguintes perguntas: levando-se em consideração as consequências de seu uso, o direito penal é um meio de intervenção adequado? Existem outras formas de intervenção, menos gravosas, que oferecem proteção mais ou igualmente efetiva àqueles bens jurídicos? Em resumo: o uso do direito penal é necessário naquele âmbito?

Especialmente em áreas complexas e já regulamentadas juridicamente, tais como a esfera tributária, a seara ambiental ou o âmbito financeiro, tem-se questionado se o direito penal é o meio mais eficiente de atuação. Muitas vezes, autoridades administrativas atuam com grande desenvoltura e conhecimento técnico, faltando-lhes apenas uma estrutura melhor para a aplicação efetiva e satisfatória de sanções. Também ocorre de o direito penal apresentar tamanha dificuldade para atuar em alguns âmbitos - em razão da complexidade e especificidade da matéria - que acaba por se revelar ineficiente e tãosomente simbólico.

para pequenos delitos, crimes patrimoniais (cometidos sem violência ou grave ameaça à pessoa), delitos que envolvem questões morais e uso de entorpecentes". (Idem, p. 367)

119 ANDRADE, Manuel da Costa. A "dignidade penal" e a "carência de tutela penal" como referências de uma doutrina teleológica-racional do crime. Revista Portuguesa de Ciência Criminal, Coimbra, ano 2, tomo 2, p. 173-205, abr.-jun. 1992. 
No tocante aos crimes contra o Mercado de Capitais, com especial ênfase ao uso indevido de informação privilegiada (insider trading), uma parcela minoritária da doutrina estrangeira defende a legitimidade de sua utilização. ${ }^{120}$ Tal corrente sustenta uma série de pontos benéficos decorrentes da utilização da informação privilegiada.

Tal posição de defesa da utilização da informação privilegiada, segundo aduz Ana María Pietro Del Pino, é decorrente de influência da chamada Escola de Chicago $^{121}$, e se traduz na assunção plena de todos os efeitos positivos da utilização da informação privilegiada, motivo pelo qual se opõem a sua proibição. A autora espanhola observa, porém, que os adeptos desta corrente reconhecem a existência de efeitos negativos. Nesse diapasão, nem toda operação com informação privilegiada contribuiria para o melhor funcionamento do mercado. Esta característica só se verificaria quando a informação é empregada por quem pode aplicá-la de forma mais eficiente, vale dizer, a informação se afigura como único mecanismo remuneratório capaz de compensar de forma satisfatoriamente proveitosa o trabalho dos membros empreendedores de uma sociedade emissora no mercado de valores mobiliários. ${ }^{122}$

Monroy Antón descreve, de forma sintetizada, as principais razões defendidas por aqueles partidários da utilização de informação privilegiada:

i) os proveitos obtidos com o uso da informação privilegiada são produto de uma maior inventvidade ou astúcia de quem as obtém e utiliza, e, portanto, os agentes tem o direito a estes;

\footnotetext{
${ }^{120}$ Esther Hernández Sainz aponta a obra do professor norte-americano Henry Manne, datada de 1.966 e denominada Insider Trading and the stok market, como ponto de partida e principal influenciadora de tal corrente doutrinária. (Op. cit., p. 187)

${ }^{121}$ Sobre a importância da Escola de Chicago: "No âmbito puramente metodológico, depois da escola de Chicago, não há qualquer política criminal séria que não se baseie em estudos empíricos da criminalidade na cidade. A criminologia passa a ser o substrato teórico para intervenção político-criminal no combate à criminalidade. O próprio direito penal terá que buscar articular sua atuação de uma maneira convergente com o ideário da teoria acima estudada. Políticas preventivas ou repressivas sem exames prévios da realidade podem criar uma disfunção prejudicial aos interesses da comunidade, com investimentos de recursos da comunidade de uma forma incompatível com os interesses dos habitantes da cidade. [...] A escola de Chicago, também conhecida por teoria da ecologia criminal, produziu grandes conseqüências metodológicas, por centrar o estudo em investigações empíricas dentro de cada cidade. Sua primeira e grande consequiência é priorizar a ação preventiva, minimizando a atuação repressiva do Estado. O controle social informal deve ser reforçado, dando-se menor importância ao controle social formal, que tem posição acessória em relação ao controle primário. Além das contribuições na esfera da política criminal, especialmente no que concerne à prevenção da criminalidade de massas, produziu substanciosas influências na órbita do direito penal, principalmente quanto às questões ambientais [...] ". (SHECAIRA, Sérgio Salomão. Op. cit., p. 183-184 e 364)

122 Op. cit., p. 42
} 
ii) a atuação dos insiders não provoca qualquer quebra de estabilidade econômica aos investidores, ninguém resultaria efetivamente prejudicado;

iii) essa atação fomenta a livre formação dos preços e ajuda para que os valores adquiram seu valor econômico real;

iv) se evita altas e baixas súbitas nos mercado de valores mobiliários, pois se está antecipando de forma progressiva a variação que sofrerão os títulos quando a informação chegue de forma extensiva ao resto dos participantes do mercado;

v) a utilização de informação privilegiada estimula a atividade empresarial dos diretores e administradores das companhias emissoras; vi) a desigualdade entre investidores é uma característica intrínseca ao mercado de valores mobiliários, motivo pelo qual não haveria razão para a proibição do insider trading. ${ }^{123}$

Como argumentos contrários aos acima expostos, se poderia aduzir, em primeiro lugar, que existe a necessidade de manutenção do princípio da igualdade entre os investidores, ainda que tal signifique uma isonomia de acesso às informações. Outro aspecto, apontado pelo autor espanhol, diz respeito à necessidade de que exista uma certa uniformidade entre todos os mercados de valores internacionais, pois a aceitação da conduta em um deles implicaria em uma resistência dos investidores para com tais mercados, ante o total desprestígio que tais operações causam ao mercado. Por fim, aponta que tais condutas geram uma desconfiança generalizada e um efeito negativo quanto ao nível de investimentos. ${ }^{124}$

Esther Hernández Sainz, por sua vez, vai além, ao afirmar que não decorre qualquer efeito positivo com a desregulamentação do uso de informação privilegiada, e aponta como consequiências negativas da adoção de tal medida uma perda de eficiência dos mercados e a geração de uma ineficiência no funcionamento interno das sociedades emissoras. $^{125}$

Há ainda aqueles que defendem uma auto-regulação do Mercado de Capitais. Tais propostas, contudo, não traduzem o abandono total do mercado à mercê de seus atores; mas sim propõem uma efetiva auto-regulação do Mercado de Capitais. Nesse contexto, restaria afastada a ingerência do Poder Público sobre o Mercado de Capitais; mas, por outro lado, o próprio mercado se ocuparia de afastar e repelir os responsáveis pelas práticas ilícitas e inadequadas.

\footnotetext{
${ }^{123}$ Op. cit., p. $65-66$

${ }^{124}$ Idem, p. 66
} 
Consoante aponta Otávio Yazbek, a proposta por uma auto-regulação não significa ausência de regulação:

[...] inicialmente cumpre reconhecer que ela é, de fato, regulação da atividade econômica, sendo objeto de uma imposição e não fruto de 'forças equilibradoras' do mercado. Trata-se, assim, de uma regulação 'artificial', imposta, ainda que o seja pela própria coletividade dos agentes regulados. Evidencia-se, com isso, o segundo aspecto da autoregulação, o fato de ela resultar de uma organização coletiva que impõe uma ordem, um conjunto de regras ou procedimentos a seus membros ela não nasce do conjunto de operações, mas de uma estrutura que se destaca daquelas operações e dos agentes que as realizam e que, sobre eles, deverá atuar. Por fim, do até aqui exposto ressalta também, o caráter extra-estatal da auto-regulação, que é desenvolvida por órgãos coletivos privados. ${ }^{126}$

Nesse sentido, afirma o autor, no que diz respeito ao Mercado de Capitais, a auto-regulação se justifica em face "da maior proximidade com a atividade regulada - que por vezes se dá 'dentro' do agente regulador (o caso das bolsas)”. Nesse contexto, afirma que "o principal campo para as atividades de auto-regulação no mercado financeiro é o das estruturas bursáteis, o que decorre até, quase naturalmente, das atividades de organização e de administração de sistemas de negociação e da necessidade de proteção dos mecanismos de formação dos preços". 127

No Brasil, de certa forma é conferido às bolsas um papel auxiliar na regulação do Mercado de Capitais, ${ }^{128}$ contudo, o sistema pátrio estabeleceu expressamente a opção por um mercado regulado, papel este desempenhado, consoante visto, pela CVM.

Não obstante não se pretender na presente dissertação realizar uma averiguação científica acerca da validade das teorias favoráveis à utilização da informação privilegiada, parece claro que tais condutas são lesivas, ou ao menos colocam em risco a eficiência do mercado de valores mobiliários e os interesses dos investidores, não se podendo admitir sua ampla desregulamentação. Todavia, a questão que se impõe é se o controle exercido na esfera administrativa já é suficiente para a proteção do mercado (ou

\footnotetext{
${ }^{125}$ Op. cit., p. $185-211$

${ }^{126}$ Op. cit., p. 208-209

${ }^{127}$ Idem, p. 210-211
} 
pode ser suficiente, desde que algumas alterações sejam realizadas) ou se é necessário o uso do direito penal para sua tutela.

No âmbito da doutrina estrangeira, encontram-se diversos posicionamentos favoráveis à penalização dos crimes contra o Mercado de Capitais.

Frederico de Lacerda da Costa Pinto faz uma análise do merecimento e necessidade da pena à luz da constituição portuguesa:

A intervenção de diversas entidades com poderes de Direito Público nesta área e nesta matéria não é, pois, um bem em si, mas antes uma forma de tutelar bens e valores que merecem essa protecção. $\mathrm{O}$ merecimento de tutela sancionatória destes bens radica, de uma forma geral, no facto de estar em causa a regularidade e a eficiência de um sector do sistema financeiro, reconhecido constitucionalmente (art. $101^{\circ}$ da Constituição), que desempenha funções econômicas essenciais, como a diversificação das fontes de financiamento das empresas, a aplicação de poupanças das famílias ou a gestão de mecanismos de cobertura de risco de actividades e de investimentos. O mercado de valores mobiliários permite que o capital se transforme em investimento e este em fonte de financiamento de entidades económicas. [...] A protecção destas funções económicas é, de acordo com o texto constitucional, uma 'incumbência prioritária do Estado' que deve, nomeadamente, assegurar o 'funcionamento eficiente dos mercados' e a repressão das 'práticas lesivas do interesse geral' (art. $81^{\circ}$ al. e da Constituição). ${ }^{129}$

Ainda quanto à doutrina portuguesa, José de Faria Costa e Maria Elisabete Ramos também se posicionam de forma favorável à utilização do direito penal como via adequada à tutela do bem jurídico protegido:

Considerada a natureza censurável e ilícita do abuso de informação, outro passo foi dado: o de que tal comportamento devia ascender à dignidade de conduta jurídico-criminalmente relevante. Embora a experiência de várias ordens jurídicas - designadamente a nossa mostre que tanto a reacção ao abuso de informação como a tutela dos investidores pode passar por mecanismos ou instrumentos não penais, é certo que a tutela penal tem sido considerada como necessária e imprescindível. A intervenção do direito penal no universo dos mercados de valores mobiliários justifica-se, tendo em conta a inoperatividade de sanções civis quando referidas transacções efectuadas em mercados de

\footnotetext{
128 artigos $8^{\circ}, \S 1^{\circ}$, e $17, \S$ único, da Lei 6.385/76

129 PINTO, Frederico de Lacerda da Costa. O novo regime de crimes e contra-ordenações no código dos valores mobiliários. Coimbra: Almedina, 2000, p. 17-18
} 
anônimos e a insuficiência da disciplina não penal para combater as condutas próprias do insider trading. ${ }^{130}$

Monroy Antón, por sua vez, afirma que ainda que o direito administrativo sancionador e o direito civil sejam suficientes para representar uma proteção das condutas ilícitas que afetam o bem jurídico, tal situação não deve ser óbice à atuação do direito penal com a mesma finalidade. Para o autor espanhol, parece claro que as agressões ao bem jurídico podem revestir gravidades distintas e, de acordo com tal parâmetro, devem as condutas ser sancionadas com maior ou menor gravidade por um tipo de direito ou outro. Assim, as ações mais graves ou de maior periculosidade deverão ser enfrentadas pelo direito penal. ${ }^{131}$

Como contraponto, a posição de Daniel Entrena Ruiz, que reconhece a maior efetividade do direito administrativo sancionador, não apenas por favorecer uma prevenção em maior grau que o direito penal, mas por ser mais eficaz contra as condutas lesivas ao Mercado de Capitais, especialmente o insider trading. Pondera ainda que a utilização do direito administrativo sancionador estaria mais de acordo com o princípio da intervenção mínima e, quanto ao tipo penal da legislação espanhola, afirma não existir qualquer diferença que indique que a conduta tipificada é mais grave que o ilícito administrativo. Por fim, propõe a derrogação do tipo penal ou, ao menos, a sua aplicação única e exclusivamente para os casos mais graves. ${ }^{132}$

Certamente se está diante de matéria complexa, que se afasta da temática afeita ao direito penal tradicional. Não se pode negar, ademais, que o órgão regulador do Mercado de Capitais possui uma especialidade técnica e instrumentos de verificação dos quais não dispõem a justiça penal e as autoridades policiais.

Caso a opção seja pela atuação da esfera penal, deve-se, a todo custo, evitar a mera utilização simbólica do direito penal por meio de mera normatização. ${ }^{133}$

\footnotetext{
130 COSTA, José Francisco de Faria; RAMOS, Maria Elisabete. O crime de abuso de informação privilegiada (insider trading) - a informação enquanto problema jurídico-penal. Coimbra: Coimbra Editora, 2006, p. 31

${ }^{131}$ Traduzido do original. Op. cit., p. 133

${ }^{132}$ ENTRENA RUIZ, Daniel. El empleo de información privilegiada en el mercado de valores: un estudio de su régimen administrativo sancionador. Navarra: Editorial Arazandi, 2006, p. 405

133 "[...] parece inevitável certo grau de controle penal quanto à Economia. A questão posta versa sobre a forma pela qual isso deve se dar, em que medidas ela se torna aceitável e de forma a mitigação do contorno
} 
Nesse contexto assume especial relevância o estudo acerca do bem jurídico, referente material necessário da norma penal. Uma solução plausível para se verificar a pertinência da intervenção penal no Mercado de Capitais consiste na aferição acerca do bem juridicamente tutelado pelo direito administrativo sancionador, e do bem jurídico protegido pela norma penal. Dessa forma, a tutela penal no Mercado de Capitais somente se justificará caso se identifique um bem jurídico diverso - ainda que relacionado daquele tutelado pela norma reguladora administrativa, adequando-se à sua função subsidiária. Mas não é só. O bem jurídico deverá necessariamente estar dotado de um referencial individual, excluindo-se proibições fundadas na consideração de elementos do Mercado de Capitais como fins em si mesmos, ou designados à tutela de interesses puramente estatais.

Além da identificação do bem jurídico, que será objeto de estudo no capítulo 4 da presente dissertação, se configura indispensável uma análise acerca da legitimidade da intervenção penal por meio da aplicação do princípio da proporcionalidade, vale dizer, restará saber se os valores que se busca tutelar são efetivamente os mais relevantes (relevância do bem jurídico), bem como se a tutela de tais bens se configura necessária (idônea para evitar que se produzam comportamentos lesivos ao bem jurídico, sem provocar danos maiores daqueles que tenta evitar); e, por fim, se a imposição de pena é realmente necessária (se não existem outros meios no ordenamento jurídico capazes de alcançar um nível de satisfação mais eficiente com custos menores).

Trata-se, pois, da maior e mais objetada dúvida do tratamento penal do Mercado de Capitais. Entretanto, para o seu deslinde, faz-se necessário um aprofundar mais crítico em suas bases, a partir do qual poder-se-á dar sua verificação penal. 


\section{O PROCESSO DE CRIMINALIZAÇÃO DA TUTELA PENAL DOS MERCADOS}

\subsection{Simbolismo e nova política criminal}

A expressão "simbolismo penal" tem sido usada de modo bastante significativo por amplos setores da doutrina para se referir, de maneira crítica, à criação de leis penais para satisfazer anseios ou clamores sociais, buscando-se atingir apenas efeitos ilusórios, sem alterar efetivamente a realidade fática.

Por meio da criminalização desenfreada de condutas, o legislador transmitiria à população a mensagem de que está agindo; de que a matéria objeto de preocupação é relevante; e de que os problemas serão solucionados. A sociedade, por sua vez, reduziria suas reivindicações em torno do assunto, pressupondo ter sido resolvido pelo legislador.

Cria-se, assim, uma nova política criminal que pretende não mais proteger bens jurídicos relevantes socialmente, mas apenas transmitir ilusões e falsas soluções.

Entretanto, tais criminalizações não costumam levar em conta a capacidade de o direito penal lidar com a matéria, suas possibilidades de efetividade, tampouco se há ou não um bem jurídico a embasar a norma penal. Díez Ripollés descreve com precisão as características do modo de agir legislativo ao se valer do simbolismo penal:

Assim, entramos no reino do proceder legislativo declarativo-formal, cuja pretensão fundamental é a de traduzir na norma legal, de modo mais fiel e contundente possível o estado atual das opiniões coletivas sobre uma determinada realidade social conflitiva, e que está distante de qualquer consideração sobre a medida em que a norma em questão pode colaborar para a solução do problema. ${ }^{134}$

O que se vê, como resultado do simbolismo penal, é a criação de normas penais ilegítimas e ineficientes, que não obedecem aos princípios penais mais comezinhos,

${ }^{134}$ DÍEZ RIPOLLÉS, José Luis. El derecho penal simbólico y los efectos de la pena. Actualidad Penal, Madrid, fasc. 1, jan. 2001, p. 3, tradução nossa 
não se acomodam às finalidades que deveriam apresentar as penas em um Estado democrático de direito, bem como não conseguem ter aplicação prática efetiva. ${ }^{135}$

Paulo Silva Fernandes pondera que o direito penal, ao tornar-se simbólico, “arrisca-se a fugir do direito penal”, posto que ao se relativizar, politizar ou administrativizar, buscará referenciais diversos dos seus para conseguir maior efetividade. $^{136}$

Silva Sánchez, por seu turno, aponta que tal função simbólica de início pode até ser benéfica, pois traz à população em geral uma sensação de segurança e efetividade. Contudo, a criminalização de condutas desprovida de uma eficaz proteção a bens jurídicos certamente se mostrará ineficiente ao longo do tempo, acabando por levar o direito penal a uma situação de descrédito. ${ }^{137}$

Não se pode, também, ignorar a atuação dos denominados "gestores atípicos da moral" (atypische Moralunternehener) - nas palavras de Silva Sánchez: expressão com a qual se designam alguns novos gestores da moral coletiva (e do recurso ao Direito Penal, naquilo que aqui especialmente interessa)" - no sentido de fomentar criminalizações desse gênero. $^{138}$

É inegável que toda norma penal está dotada de certo valor simbólico enquanto expressão de comportamentos socialmente indesejados, ${ }^{139}$ mas este não pode ser um fim em si mesmo, tal qual observa Roxin:

\footnotetext{
${ }^{135}$ Conforme aponta Renato de Mello Jorge Silveira: “A mera construção de novos tipos penais, ou ainda, um simples endurecer penal, além de propiciar uma falsa ilusão de resolução dos problemas sociais, acaba por desvirtuar o sistema por completo. Não é compatível nem com a dogmática moderna, nem com os princípios e garantias assegurados pelo Estado Democrático de Direito". (Direito penal supra-individual. Op. cit., p. 170)

${ }^{136}$ Op. cit., 53

${ }^{137}$ Aproximación al derecho penal contemporáneo. Barcelona: Bosch Editor, 2002, p. 305-306

138 "Se os tais 'gestores' vinham sendo tradicionalmente determinados estamentos burgueses-conservadores, hoje adquirem tanta ou mais relevância em tal papel as associações ecologistas, feministas, de consumidores, de vizinhos [...], pacifistas [...], antidiscriminatórias [...] ou, em geral, as organizações não governamentais (ONGs) que protestam contra a violação de direitos humanos em outras partes do mundo. Todas elas encabeçam a tendência de uma progressiva ampliação do Direito Penal no sentido de uma crescente proteção de seus respectivos interesses. [...] A reviravolta tem sido tamanha que aqueles que outrora repudiavam o Direito Penal como braço armado das classes poderosas contra as 'subalternas' agora clamam precisamente por mais Direito Penal contra as classes poderosas". (A expansão do direito penal .... Op. cit., p. 63-64)

${ }_{139}$ Quanto a este efeito "simbólico" inerente às normas penais, Hassemer os denomina como efeito "comunicativo", imprescindível à existência da norma, tratando-se de uma descrição, vale dizer, encerra uma
} 
Dado que todas as leis penais tem um impacto simbólico mais ou menos grande por dever operar sobre a formação da consciência da população, os elementos 'simbólicos da legislação não são inadmissíveis de modo geral. Tudo depende de até que ponto se segue garantindo suficientemente a referência ao bem jurídico. No caso de preceitos que estendem amplamente a punibilidade ao campo prévio às ações concretas ou que castigam meras manifestações da atitude interna, pode ser absolutamente duvidosa sua admissibilidade desde os pontos de vista do Estado de Direito. ${ }^{140}$

Nesse contexto, cabe especial atenção ao se tratar da tutela penal de interesses supra-individuais, como observa Renato de Mello Jorge Silveira:

De fato, as normas podem descrever funções retóricas ou funções simbólicas. As primeiras caracterizam-se pelas resoluções diretas do problema jurídico-penal, enquanto as segundas atingem seus efeitos na opinião pública. Essa ambivalência é presente em praticamente todas as disposições legais. $\mathrm{O}$ grande problema vivido, sobremaneira, no caso difuso, consiste no fato da assunção do caráter absoluto assumido pelo efeito simbólico. Está a se perder, com isso, a função retórica. Assim, não raras vezes, despreza-se a tudo e a todos, para que se venha a valorizar, quase que exclusivamente, a importância penal ante a opinião pública. Perdendo a confiança dogmática no que se tem cientificamente por certo, não podendo cumprir suas funções de proteção, a função simbólica do Direito Penal acaba por obstaculizar a função instrumental deste, ilegitimando a integralidade do próprio sistema. ${ }^{141^{3}}$

Uma vertente do simbolismo penal apontada pela doutrina seria a criminalização de condutas típicas das classes mais altas, passando à população a impressão de que também "os ricos e poderosos" estariam sujeitos ao sistema penal ${ }^{142}$. Dessa forma, o legislador conseguiria minimizar a percepção de que o sistema penal é desigual e preconceituoso, além de combater, simbólica e ilusoriamente, as diferenças sociais. Trata-se, como afirma Paulo Silva Fernandes, da 'técnica do bode expiatório'. ${ }^{143}$

perspectiva descritivo-analiítica. (Derecho Penal Simbólico y Protección de Bienes Jurídicos. Pena y Estado: función simbólica de la pena. n. 1, Barcelona: PPU, 1991, p. 28

${ }^{140}$ Derecho Penal Parte General. Op. cit., p. 59, tradução nossa

${ }^{141}$ Direito PenalSsupra-individual. Op. cit., p. 172-173

142 BUSTOS RAMÍREZ, Juan. Necesidad de la pena, función simbólica y bien jurídico medio ambiente. In: Pena y Estado. Santiago de Chile: Jurídica ConoSur, 1995. p. 101. Acerca do tema, Luciano Anderson de Souza faz relevante reflexão: "Outro mecanismo de atuação simbólica do aparato penal é a tentativa estatal de incutir na população a sensação de que a repressão aos delitos é cada vez mais efetiva. Desse modo, valendo-se de operações policiais grandiosas e dirigidas contra indivíduos com certa projeção social, tenta-se transmitir ao cidadão comum a idéia de que ele não poderá desviar as suas condutas, andando na linha, sob pena de sofrer uma repressão tão ou mais rigorosa e eficaz. Passa-se a mesma sensação quando se determina o recolhimento ao cárcere de pessoas ainda inculpadas que ocupam uma posição no ápice da pirâmide socia"” (Expansão do direito penal e globalização. São Paulo: Quartier Latin, 2007, p. 157

${ }^{143}$ Op. cit., p. 53 
Quanto aos crimes contra o Mercado de Capitais, estes certamente encerram condutas praticadas tipicamente por parcelas sociais mais privilegiadas, incrementando o risco de se proceder a uma criminalização simbólica. Dessa forma, resta imprescindível a correta definição do bem juridicamente tutelado pelas normas incriminadoras, bem como uma rigorosa análise de suas estruturas típicas, a fim de evitar que se recorra a expedientes meramente simbólicos, em todo condenáveis.

\subsection{Internacionalização do Direito Penal}

Desde meados do século XX, especialmente após o término da Segunda Guerra Mundial, verificou-se uma necessidade real de sistematização e regulação de certos conflitos de interesse da coletividade mundial, tanto para questões relativas à violação generalizada e em larga escala de direitos humanos, como para aquelas decorrentes de uma economia cada vez mais internacionalizada. ${ }^{144}$

Sob esse primeiro viés, nota-se, já de algum tempo, um avanço concreto na edição de normas internacionais, como convenções e tratados, que buscam uniformizar certos princípios gerais de proteção a determinados interesses. Tal movimento culminou, inclusive, com a criação de um Tribunal Penal Internacional, para julgamento de grandes questões relativas a abusos tidos como ofensivos à humanidade.

Já no tocante a uma economia cada vez mais "mundializada", nota-se, especialmente em decorrência do incremento tecnológico, o surgimento de interesses cada vez mais internacionalizados em face da livre circulação de capital entre os países, evidentemente facilitado ante a existência de Mercados de Capitais cada vez mais interligados em razão de sua natureza dinâmica.

\footnotetext{
${ }^{144}$ Consoante aponta Maíra Rocha Machado: "Com a reconstrução econômica do pós-guerra, o aumento vertiginoso do número de atores na política econômica mundial - Organização das Nações Unidas, Banco Mundial, Fundo Monetário Internacional, entre outros - marcou o advento de alguns assuntos 'públicos' ou 'comuns' que seriam regulados por um grupo específico de países. No âmbito do direito internacional, as principais modificações ocorridas nesse período focalizaram, sobretudo, uma ampliação de objeto. [...] $\mathrm{Na}$ esfera penal, o movimento de internacionalização é impulsionado por dois fatores principais, intimamente atrelados aos avanços tecnológicos das últimas décadas: a intensa circulação transfronteira de pessoas, bens e capitais e a crescente visibilidade mundial de certos eventos locais”. (Op. cit., p. 17-18)
} 
Como decorrência, surge também uma nova espécie de criminalidade, que extrapola os limites das fronteiras territoriais e que tem facilitados seus meios de ação pela utilização tecnológica, com especial destaque para a internet. Passa o direito penal, dessa forma, a ter a necessidade de se preocupar com condutas globais, ${ }^{145}$ que se traduz em uma tendência real de sistematização e regulação de certos conflitos de interesse supranacionais. Verifica-se, pois, verdadeira internacionalização do direito penal. ${ }^{146}$

Pode-se destacar aqui o Comitê de Basiléia, que definiu uma série de princípios na busca por uma atividade bancária ética, e a atuação do GAFI - Grupo de Ação Financeira sobre a Lavagem de Dinheiro, bem como diversos tratados de cooperação mútua em matéria penal entre países. $\mathrm{O}$ foco de tais institutos, contudo, se traduz em uma preocupação muito forte, na seara do direito penal econômico, com a questão da lavagem de capitais. $^{147}$

Não se pode negar a importância da criação e do estudo de instrumentos legais eficazes no combate à lavagem de dinheiro. Este não é, porém, o foco principal do presente trabalho, restrito à questão da tutela penal dos Mercados de Capitais.

Nesse contexto, o sistema regulatório norte-americano, em razão de seu pioneirismo, acabou por influenciar a regulação dos mercados de capitais ao redor do planeta - consoante visto em apartado anterior, o atual modelo de regulação administrativa do mercado de capitais no Brasil é um exemplo claro -, inclusive no que diz respeito à criminalização da matéria.

Merece aqui especial destaque, no tocante à internacionalização do direito penal, a 'resposta' norte-americana aos recentes casos de fraudes contábeis em empresas emissoras de valores mobiliários - tendo como exemplos clássicos os casos 'Enron',

\footnotetext{
145 “ “...] crimes nos quais a denominação de internacional decorre da ênfase no aspecto fenomenológico da palavra 'crime'. Trata-se aqui, portanto, de fatos e condutas que se caracterizam por cruzar fronteiras nacionais, daí advindo sua designação de internacional". (Idem, p. 127)

${ }^{146}$ Segundo define Maíra Rocha Machado, o termo internacionalização do direito penal "designa qualquer iniciativa ou atividade que vise a compatibilizar ou reduzir os obstáculos à interação entre a intensa circulação de pessoas, bens e capitais entre países e, com ela, a crescente visibilidade mundial de determinados problemas locais, por um lado; e a existência de nítidas fronteiras nacionais de regulação jurídico-penal, por outro". (Idem, p. 13)

${ }^{147}$ Acerca do tema vide: MACHADO, Maíra Rocha. Op. cit., p. 127 e ss. ESTELLITA, Heloísa. Integração regional e direito penal. Op. cit.
} 
'Arthur Andersen' e 'WorldCom'148 - que resultou na edição, em 2.002, da SarbanesOxley Act, que estabeleceu sanções severas relacionadas à prática de fraudes corporativas, tais como a destruição, alteração ou falsificação de documentos que são objeto de investigação federal (Seção 802) e fraudes praticadas contra acionistas (Seção 807), apenadas, respectivamente, com até vinte e vinte e cinco anos de prisão. Referido diploma atribuiu também, penas de até dez anos (modalidade culposa), e vinte anos (modalidade dolosa), além de pesadas multas pecuniárias, para os administradores, auditores e contadores que fraudarem ou inserirem falsas informações em demonstrações contábeis da companhia emissora (Seção 906). Cumpre observar que o alcance da norma não está restrito às companhias norte-americanas, englobando também os administradores, auditores e contadores de sociedades estrangeiras que tenham valores mobiliários lançados em bolsas dos Estados Unidos.

No tocante às previsões penais da Sarbanes-Oxley Act podem ser feitas diversas críticas, dentre as quais vale transcrever aquelas lançadas por Renato de Mello Jorge Silveira e Alamiro Velludo Netto:

As normas penais contidas na legislação promulgada, tendo em vista sua própria filosofia inspiradora, demarcam todas as características de um Direito Penal simbólico, voltado às conseqüências e, ademais, com nítido caráter preventivo-pragmático. A premissa adotada é a confiabilidade no mercado, ou seja, a instrumentalização do sistema repressor no sentido de manter, nos agentes econômicos, a expectativa de veracidade acerca das notícias contábeis veiculadas pelas mais diversas empresas. Como conseqüência imediata, o diploma legislado busca evitar todo e qualquer comportamento que signifique alguma desilusão a estas expectativas. A forma de contenção, por sua vez, não poderia ser outra senão a utilização do Direito Penal como prima ratio. ${ }^{149}$

Hefendehl, de igual sorte, crítica o caráter simbólico da norma norteamericana, ilustrado, conforme o autor, por slogan utilizado pelo então presidente George W. Bush: "Chega de dinheiro fácil para criminosos corporativos - só prisão". ${ }^{150} \mathrm{O}$ autor aponta ainda para outros perigos desta natureza de legislação, como objetivos vagos e

\footnotetext{
${ }^{148}$ Acerca do tema vide: BORGERTH, Vania Maria da Costa. SOX: entendendo a Lei Sarbanes-Oxley - um caminho para a informação transparente. São Paulo: Thomson Learning, 2007, p. 1 e ss.

${ }^{149}$ Op. cit., p. 201

150 Traduzido do original. HEFENDEHL, Roland. Enron, WorldCom, and the consequences: business criminal law between doctrinal requirements and the hopes of crime policy.Buffalo Law Review. Vol. 08, fev/05. Buffalo: School of Law, State University of New York at Buffalo, 2005, p. 62
} 
classificações dúbias, punições draconianas e tratamento idêntico para condutas consumadas e tentadas, ${ }^{151}$ e faz importante ressalva quanto à efetividade da norma enquanto mecanismo de governança corporativa, posto que não leva em conta a separação de tarefas entre os administradores (CEO) e membros da diretoria, as limitações na emissão de valores mobiliários e a reforma das regras legais referentes a balanços e demais demonstrações financeiras. Conclui, pois, que a Lei tenta estabelecer uma eficiente governança corporativa por meio da criação de um tratamento punitivo extremamente rigoroso aos administradores. ${ }^{152}$

Schünemann, por seu turno, afirma que a Sarbanes-Oxley Act, "em muitos aspectos, extrapola as fronteiras de uma sensível política de justiça criminal". 153

Os efeitos da Sarbanes-Oxley Act no Brasil não são sentidos apenas em termos da possibilidade de punição a administradores, auditores e contadores de companhias emissoras com papéis lançados em bolsas norte-americanas.

Em 30 de janeiro de 2.008 foi editada a Deliberação CVM 534/08, que aprovou e tornou obrigatório para as companhias abertas o Pronunciamento Técnico CPC 02, aplicável aos exercícios encerrados a partir de dezembro de 2.008, tendo como fim tornar as normas contábeis brasileiras convergentes com as práticas contábeis internacionais. Dessa forma, foram alterados os padrões contábeis estabelecidos no país para aqueles adotados pela IFRS (International Financial Reporting Standards).

Tal posicionamento, ainda que não tenha representado qualquer acréscimo em termos de legislação penal, certamente tem efeitos no tocante à aplicação do crime previsto no artigo $177, \S 1^{\circ}$, inciso I, do Código Penal, que assim estabelece

Art. 177 - Promover a fundação de sociedade por ações, fazendo, em prospecto ou em comunicação ao público ou à assembléia, afirmação falsa sobre a constituição da sociedade, ou ocultando fraudulentamente fato a ela relativo: Pena - reclusão, de um a quatro anos, e multa, se o fato não constitui crime contra a economia popular.

\footnotetext{
${ }^{151}$ Idem, p. 59-64

${ }^{152}$ Idem, p. 58-59

${ }^{153}$ The Sarbanes-Oxley Act of 2002: a german perspective. Buffalo Law Review. Vol. 08, fev/05. Buffalo: School of Law, State University of New York at Buffalo, 2005, p. 35-50
} 
$\S 1^{\circ}$ - Incorrem na mesma pena, se o fato não constitui crime contra a economia popular:

I - o diretor, o gerente ou o fiscal de sociedade por ações, que, em prospecto, relatório, parecer, balanço ou comunicação ao público ou à assembléia, faz afirmação falsa sobre as condições econômicas da sociedade, ou oculta fraudulentamente, no todo ou em parte, fato a elas relativo; [...].

No que diz respeito à tipificação das condutas lesivas ao Mercado de Capitais no Brasil - ainda que não guarde qualquer relação com a Sarbanes-Oxley Act não por acaso se deu, cronologicamente - com a edição, em outubro de 2.001, da Lei 10.303, que acrescentou os tipos penais à Lei 6.385/76 - em momento simultâneo à deflagração de diversos escândalos internacionais envolvendo companhias emissoras de valores mobiliários.

Outro exemplo claro de exacerbação da preocupação internacional em incrementar a regulação do Mercado de Capitais, como decorrência de tais escândalos, é a própria diretiva 2003/6/CE, a qual, consoante já analisado, procurou unificar e harmonizar conceitos e definições, com reflexos diretos nas legislações penais dos países membros. Ainda, no mesmo ano, o governo alemão manifestou oficialmente posição no sentido de demandar o incremento de penas nos casos de ofensas dolosamente praticadas contra o Mercado de Capitais. ${ }^{154}$

Ocorre que, muito mais do que mera harmonização ou influência, a edição de normas como a Sarbanes-Oxley Act acabam por representar em verdadeira imposição, vale dizer, consoante afirmado por Renato de Mello Jorge Silveira e Alamiro Velludo Salvador Netto, uma pretendida "unilateral modificação legislativa com pretensões supranacionais". Os autores, contudo, impõem relevante ressalva: "A internacionalização pode até ser meta, mas deve ser antecedida de um discutir profundo". 155

\footnotetext{
${ }^{154}$ HEFENDEHL, Roland. Enron, ... Op. cit., p. 62

155 Op. cit., p. 210 Tal política expansivista, segundo aponta Hefendehl, não está restrita à norma ora em comento, mas também é verificada com relação a legislações orientadas ao combate à lavagem de capitais ou a proteção de direitos autorais. HEFENDEHL, Roland. Enron, ... Op. cit., p. 67
} 


\subsection{Realidade comparada}

\subsubsection{Estados Unidos da América}

O sistema de regulação do Mercado de Capitais dos Estados Unidos da América teve sua criação sob forte influência da crise econômica de 1929, com o objetivo de pôr fim a ações meramente especulativas, práticas que até então prevaleciam, haja vista a quase ausência de regulação específica. ${ }^{156}$

O primeiro diploma legal a efetivamente regular a matéria foi a Securities Act, de 1933, que trouxe em seu bojo uma nítida preocupação em proteger o investidor. Referido diploma, em sua seção 17(a), dispõe que haverá punição para qualquer pessoa que, mediante o uso de qualquer meio ou instrumento de comunicação no comércio interestadual, ou mediante o uso do correio, publique ou faça circular alguma notícia, circular, anúncio, artigo, carta, etc., de conteúdo falso, ainda que não chegue a recomendar a compra ou venda de ações, pelo efeito que possa produzir aos investidores. ${ }^{157}$

Em 1.934 é editada a Securities and Exchange Act, que além de criar a Securities and Exchange Commission, órgão regulador do Mercado de Capitais norteamericano, tratou de dar uma melhor formatação à norma de 1933, e pela qual, na seção 10, dispõe expressamente acerca da possibilidade de punição contra atos de manipulação ou fraude em negociações com valores mobiliários, incluindo-se neste contexto o chamado insider trading, ao definir como prática ilegal:

[...] que qualquer pessoa, direta ou indiretamente, por qualquer meio ou instrumento de comércio interestadual, correio, ou por qualquer meio de alguma bolsa nacional, [...] utilize ou empregue, em relação com a compra ou venda de qualquer título ou valor, registrado ou não em bolsa, qualquer meio manipulador ou enganoso, ou manipule de forma

\footnotetext{
156 Sobre o tema vide: RUIZ RODRIGUEZ, Luis Ramon. Protección penal del mercado de valores. Valencia: Tirant Monografias, 1997, p. 131 e ss.

${ }^{157}$ Conforme texto original - tradução nossa: "It shall be unlawful for any person in the offer or sale of any securities or any security-based swap agreement (as defined in section 206B of the Gramm-Leach-Bliley Act [15 USCS $\S 78 \mathrm{c}$ note]) by the use of any means or instruments of transportation or communication in interstate commerce or by use of the mails, directly or indirectly: 1. to employ any device, scheme, or artifice to defraud, or 2. to obtain money or property by means of any untrue statement of a material fact or any omission to state a material fact necessary in order to make the statements made, in light of the circumstances under which they were made, not misleading; or 3. to engage in any transaction, practice, or course of business which operates or would operate as a fraud or deceit upon the purchaser."
} 
contrária as regras que a Comissão prescreva como necessárias e apropriadas ao interesse público e para a proteção dos investidores. ${ }^{158}$

Em 1.942, a Securities and Exchange Commission edita a Regra 10 b-5, que ampliou o alcance de proteção da seção 10 da Securities and Exchange Act aos vendedores de títulos no mercado. ${ }^{159}$

Consoante observa Monroy Antón, as principais características da norma norte-americana consistem em:

a) fraude ou manipulação, em um conceito amplo, incluindo-se qualquer forma de atuação que tenha efeito manipulador ou fraudulento, como as chamadas meias-verdades, atos não verbais, etc.;

b) relevância da informação, assim entendida pela jurisprudência dos Estados Unidos como uma grande probabilidade de que o fato omitido teria tido importância nas deliberações do acionista médio ${ }^{160}$;

c) intencionalidade;

d) erro, devendo o lesado provar que atuou como resultado das manipulações da contra-parte;

e) descumprimento de um dever de lealdade. ${ }^{161}$

As penas cominadas pelo descumprimento das regras da Securities and Exchange Act são estabelecidas pela seção 32, e preveem o limite máximo para as penas de multa em vinte e cinco e cinco milhões de dólares, respectivamente, para pessoas jurídicas e pessoas físicas. Já, no tocante à pena privativa de liberdade, esta tem seu limite máximo estabelecido em 20 anos de prisão.

\footnotetext{
${ }^{158}$ Conforme texto original - tradução nossa: "It shall be unlawful for any person, directly or indirectly, by the use of any means or instrumentality of interstate commerce or of the mails, or of any facility of any national securities exchange: a) 1 . To effect a short sale, or to use or employ any stop-loss order in connection with the purchase or sale, of any security registered on a national securities exchange, in contravention of such rules and regulations as the Commission may prescribe as necessary or appropriate in the public interest or for the protection of investors. 2. Paragraph (1) of this subsection shall not apply to security futures products; b) To use or employ, in connection with the purchase or sale of any security registered on a national securities exchange or any security not so registered, or any securities-based swap agreement (as defined in section 206B of the Gramm-Leach-Bliley Act), any manipulative or deceptive device or contrivance in contravention of such rules and regulations as the Commission may prescribe as necessary or appropriate in the public interest or for the protection of investors".

${ }^{159}$ PROENÇA, José Marcelo Martins. Insider trading - regime jurídico do uso de informações privilegiadas no mercado de capitais. São Paulo: Quartier Latin, 2005, p. 214

${ }^{160}$ Segundo aponta Thomas Lee Hazen a Suprema Corte dos Estados Unidos definiu como informação relevante aquela que o investidor razoável poderá considerar como significativa para tomar uma decisão de investir. (Principles of securities regulation. St. Paul: Thompson, 2006, p. 258-259)
} 


\subsubsection{Europa}

A tutela penal do Mercado de Capitais tem suas origens remotas no Código Penal Francês de $1.810,{ }^{162}$ que tratava da manipulação de mercado como uma das formas possíveis do crime de manipulação de preços, e que teve forte influência sobre os demais sistemas legais da Europa ao longo do século XIX, dentre os quais destacamos o Código Penal Português de 1.852, sob a forma de manipulação do preço de "mercadorias, gêneros, fundos ou quaesquer outras cousas que forem objecto de commercio". ${ }^{163}$

No tocante ao uso indevido de informação privilegiada, de igual sorte, o tratamento pioneiro veio da França, em $1970^{164}$, com a previsão de pena de prisão de dois meses a dois anos, além de multa de cinco milhões de francos a até quatro vezes o valor do benefício indevidamente alcançado, nos casos de uso indevido, em nome próprio ou por intermédia pessoa, de informação privilegiada; assim entendida a informação relevante ainda não levada a conhecimento público. Referido dispositivo trazia como sujeitos ativos os presidentes, diretores gerais, administradores, membros de conselho, representantes permanentes e quaisquer outras que, por conta de sua atividade profissional ou função, dispusessem da informação privilegiada.

Segundo aponta Monroy Antón ${ }^{165}$, a lei francesa nasce sob influência do chamado Informe Segré, reunião de experts sobre a integração dos Mercados de Capitais, ocorrida em Bruxelas no ano de 1967, que recomendou aos Estados membros a homogeneização dos níveis de informação mediante reformas em suas respectivas normativas contábeis e societárias, e trouxe como conseqüência o surgimento do Código Europeu de boas condutas referentes a transações com valores mobiliários, publicado como simples recomendação da Comissão Européia, de 25 de julho de $1.977 .{ }^{166}$ Tratou-se, contudo, de mera recomendação, desprovida de caráter imperativo.

${ }^{161}$ MONROY ANTÓN, Antonio J. El delito de abuso de información privilegiada en el mercado de valores. Madrid Dijusa, 2006, p. 114

${ }^{162}$ Acerca do tema: PINTO, Frederico de Lacerda Costa. O novo regime dos crimes e contra-ordenações no Código dos Valores Mobiliários. Coimbra: Almedina, 2000, p. 38-39

163 Artigo $276^{\circ}$

${ }^{164}$ Lei 70-1208, de 23 de setembro de 1970.

165 Op. cit., p. 119

166 Referido Código estabelecia em sua informação Y9, como princípio, o resguardo ao trato igualitário do público investidor no tocante à informação: "Todas las personas que disponen, debido al ejercicio de su professión o de su función, de una información confidencial que no ha sido hecha pública, referente a una sociedad o sobre el mercado de sus títulos o sobre cualquier acontecimiento relevante para el mercado en 
Consoante o autor espanhol, ${ }^{167}$ a legislação francesa sofreu inúmeras críticas da doutrina por deixar de fora do seu âmbito de tutela os grandes acionistas e demais pessoas que poderiam ter obtido a informação privilegiada por outros meios que não profissionais.

Ainda em termos comunitários, talvez o grande marco de combate ao uso indevido de informação privilegiada tenha sido a edição da Diretiva 89/592/CEE, de 13 de novembro de 1.989, sobre coordenação das normativas relativas às operações com informação privilegiada, e destinada a garantir transparência informativa e a leal utilização da informação. Ela recomendava expressamente a repressão ao insider trading.

Conforme Monroy Antón, ${ }^{168}$ essa normativa teve efeito influenciador em diversos dos regramentos europeus, especialmente no tocante à definição de informação privilegiada, ${ }^{169}$ e atinge seu ponto máximo ao influenciar a criação da legislação italiana de proteção ao Mercado de Mapitais e combate ao insider trading, até então inexistente, representando o surgimento da CONSOB, órgão regulador do mercado naquele país.

Em Espanha, a matéria passou a ser regulada a partir de 1988, com a edição da Ley de Mercado de Valores, ${ }^{170}$ que tratou de expressamente a vedar a prática do uso de informação privilegiada, sendo posteriormente tipificada como crime, apenado com um a quatro anos de prisão, pelo Código Penal de $1.995 .{ }^{171}$

general, que fuera susceptible, caso de ser publicada, de influir de manera sensible sobre la cotización de uno o varios valores mobiliarios, se abstendrá de realizar directa o indirectamente, toda operación que explote esta información, así como de comunicarla a un tercero para que se beneficie de ella antes de que sea hecha pública."

${ }^{167}$ Op. cit., p. 119.

168 Idem, p. 120.

169 A legislação francesa passa a definir informação privilegiada como: "informação não pública, precisa, concernente a um ou vários emissores de valores, um ou mais valores mobiliários, um ou mais contratos a termo negociáveis, um ou mais produtos financeiros, que podem ter incidência sobre o curso do valor; do contrato ou do produto financeiro concernente." Já a legislação belga: "que não tenha sido levada a público, com caráter suficientemente preciso e concernente a um ou mais emissores de valores mobiliários ou outros instrumentos financeiros, ou a um ou vários valores mobiliários ou outros instrumentos financeiros, e que se levada a público teria uma natureza tal que influiria de maneira sensível no curso dos valores ou dos instrumentos financeiros”. (Cf. MONROY ANTÓN, Antonio J. Op. cit., p. 119-120)

${ }^{170}$ Lei $24 / 1988$

171 “Artículo 285.1 - Quien de forma directa o por persona interpuesta usare de alguna información relevante para ala cotización de cualquier clase de valores o instrumentos negociados en algun mercado organizado, oficial o reconocido, a la que haya tenido acceso reservado con ocasión del ejercício de su actividad profesional o empresarial, o la suministrare obteniendo para sí o para un tercero un benefício económico superior a 600.000 euros o causando uno prejuicio de idéntica cantidad, será castigado con la pena de prisión 
Ponto a ser destacado quanto à legislação espanhola diz respeito à opção do legislador daquele país em estabelecer um limite autorizador da intervenção penal. Vale dizer, ao dispor que as condutas lesivas ao Mercado de Capitais somente se tornarão típicas quando o benefício econômico ou o prejuízo correspondente a tais práticas sejam iguais ou superiores a seiscentos mil euros. Trata-se de característica comum no direito penal espanhol, verificada também quanto aos crimes contra a ordem tributária, ${ }^{172} \mathrm{em}$ eleger um determinado valor que distinguirá a aplicação da sanção penal da administrativa. Esta posição se justifica pela aplicação do princípio do ne bis in idem, expresso no artigo 25.1 da Constituição espanhola, e segundo o qual a mesma conduta não pode ser objeto de duas sanções diferentes. Dessa forma, qualquer conduta que implique em vantagem ou prejuízo menor do que seiscentos mil euros será sancionada pela via administrativa. ${ }^{173}$

Portugal, por sua vez, tipificou o uso indevido de informação privilegiada em seu Código das Sociedades Comerciais, de 1.987, agregando sanções de cunho penal, civil e societário. Com a edição do Código de Valores Mobiliários, em 1.999, o legislador português consolidou a repressão ao insider trading e à manipulação de mercado.

No caso do crime de uso indevido de informação privilegiada, verifica-se uma valoração distinta quanto aos sujeitos ativos do delito. Dessa forma, a norma penal portuguesa pune com maior gravidade (prisão de até três anos ou multa) aqueles considerados insiders primários, em outras palavras, membros de órgãos de administração ou fiscalização, acionistas, prestadores de serviço em caráter permanente ou eventual das sociedades emissoras, e também aqueles que tiveram acesso à informação privilegiada por força do exercício de uma função pública ou a obtiveram por alguma forma ilícita. Quanto

de uno a cuatro años, multa de tanto al triplo del beneficio obtenido o favorecido e inhabilitación especial para el ejercicio de la profesión o actividad de dos a cinco años".

"Artículo 285.2 - Se aplicará la pena de prisión de cuatro a seis años, la multa del tanto al triplo del benefício obtenido o favorecido e inhabilitación especial para el ejercício de la profesión o actividad de dos a cinco años, cuando las conductas descritas en el apartado anterior concurra alguna de las siguientes circunstancias: $1^{\circ}$. Que los sujetos se dediquen de forma habitual a tales práticas abusivas. $2^{\circ}$ Que el beneficio obtenido sea de notoria importancia. $3^{\circ}$ Que se cause grave daño a los intereses generales".

172 ANTONELI, Osvaldo Gianotti. Inadequação e ineficácia da tutela penal tributária no ordenamento jurídico brasileiro. Dissertação de mestrado apresentada à Faculdade de Direito da Universidade de São Paulo em 2008, p. 118 e ss.

${ }^{173}$ Segundo Daniel Entrena Ruiz, a não cumulatividade entre as sanções penal e administrativa se justifica, consoante a aplicação do princípio do ne bis in idem, uma vez que existe identidade entre o bem jurídico tutelado pela norma penal e a norma administrativa, que, na opinião do autor vem a ser a eficiência do 
aos insiders secundários, considerados pela norma lusitana como todos aqueles não incluídos no rol dos insiders primários, e que, obtendo acesso a uma informação privilegiada a transmitam ou, com base nela, negociem valores mobiliários, é cominada pena de prisão de até dois anos e multa de até duzentos e quarenta dias. ${ }^{174}$

Já quanto ao crime de manipulação de mercado, a pena atribuída tem o limite máximo de três anos de prisão; podendo também ser substituída por multa, sendo, de igual sorte, tipificado como crime (com pena de prisão de até dois anos e multa de até duzentos e quarenta dias), imputável aos membros de órgão de administração e responsáveis pela direção ou fiscalização das atividades de um intermediário financeiro, a omissão quanto à pratica de manipulação de mercado praticada por seus subordinados. ${ }^{175}$

Em ambos os crimes, a tentativa é punível. Ademais, o legislador português estabeleceu penas acessórias, de caráter restritivo, quanto ao exercício de atividades no mercado de capitais ('interdição'), e a publicação das sentença condenatória às expensas do condenado. ${ }^{176} \mathrm{O}$ valor dos benefícios auferidos por meio das práticas consideradas ilícitas está, também, sujeito a apreensão no curso do processo, e, sobrevindo sentença

mercado e a confiança dos investidores. (El empleo de información privilegiada en el mercado de valores: un estudio de su régimen administrativo sancionador. Navarra: Editorial Arazandi, 2006, p. 392)

174 “Artigo 378. - 1 - Quem disponha de informação privilegiada: a) Devido à sua qualidade de titular de um órgão de administração ou de fiscalização de um emitente ou de titular de uma participação no respectivo capital; ou b) Em razão do trabalho ou do serviço que preste, com carácter permanente ou ocasional, a um emitente ou a outra entidade; ou c) Em virtude de profissão ou função pública que exerça; ou d) Que, por qualquer forma, tenha sido obtida através de um facto ilícito ou que suponha a prática de um facto ilícito; e a transmita a alguém fora do âmbito normal das suas funções ou, com base nessa informação, negoceie ou aconselhe alguém a negociar em valores mobiliários ou outros instrumentos financeiros ou ordene a sua subscrição, aquisição, venda ou troca, directa ou indirectamente, para si ou para outrem, é punido com pena de prisão até três anos ou com pena de multa. 2 - Qualquer pessoa não abrangida pelo número anterior que, tendo conhecimento de uma informação privilegiada, a transmita a outrem ou, com base nessa informação, negoceie ou aconselhe alguém a negociar em valores mobiliários ou outros instrumentos financeiros ou ordene a sua subscrição, aquisição, venda ou troca, directa ou indirectamente, para si ou para outrem, é punida com pena de prisão até dois anos ou com pena de multa até 240 dias. [...]”.

175 “Artigo 379. - 1 - Quem divulgue informações falsas, incompletas, exageradas ou tendenciosas, realize operações de natureza fictícia ou execute outras práticas fraudulentas que sejam idóneas para alterar artificialmente o regular funcionamento do mercado de valores mobiliários ou de outros instrumentos financeiros é punido com prisão até três anos ou com pena de multa. 2 - Consideram-se idóneos para alterar artificialmente o regular funcionamento do mercado, nomeadamente, os actos que sejam susceptíveis de modificar as condições de formação dos preços, as condições normais da oferta ou da procura de valores mobiliários ou de outros instrumentos financeiros ou as condições normais de lançamento e de aceitação de uma oferta pública. 3 - Os titulares do órgão de administração e as pessoas responsáveis pela direcção ou pela fiscalização de áreas de actividade de um intermediário financeiro que, tendo conhecimento de factos descritos no n. $^{\circ} 1$, praticados por pessoas directamente sujeitas à sua direcção ou físcalização e no exercício das suas funções, não lhes ponham imediatamente termo são punidos com pena de prisão até dois anos ou pena de multa até 240 dias, se pena mais grave não lhes couber por força de outra disposição legal. [...]."

${ }^{176}$ Artigo $380^{\circ}$ do Código de Valores Mobiliários português 
condenatória serão revertidos aos prejudicados que tenham se habilitado e comprovado os danos no curso do processo criminal, sendo o remanescente revertido ao Estado (60\%) e ao "sistema de indenização dos investidores". 177

Por fim, quanto ao sistema penal português, cumpre informar que o legislador tipificou ainda como crime a desobediência a ordens ou mandados legítimos do órgão regulador daquele país ${ }^{178}$, bem como atribuiu a uma séria de condutas - que via de regra poderiam ser consideradas como meras infrações administrativas - , tais como a divulgação de informações incompletas, o envio de informações ou relatórios desacompanhados de parecer elaborado por auditor independente ou desacompanhadas de tradução quando escritas em outro idioma, o caráter de ilícitos de mera ordenação social. ${ }^{179}$

O sistema suíço de repressão ao uso indevido de informação privilegiada, ${ }^{180}$ consoante aponta Monroy Antón ${ }^{181}$, adota uma postura similar ao regramento português, ao distinguir os insiders primários dos secundários quanto ao grau de punibilidade. Regulamentação semelhante se verifica na Alemanha, que proibiu efetivamente a prática de insider trading apenas em 1.994, sob influência da Diretiva 89/592 e forte pressão do demais países membros da Comunidade Européia, estabelecendo sanções de natureza civil e administrativa, além da possibilidade de pena de prisão de até cinco anos. ${ }^{182}$

Conforme visto, antes da edição da Diretiva 89/592, a Itália permanecia como único país sem qualquer regulação (civil, administrativa ou penal) no tocante a práticas ilegais no Mercado de Capitais, situação que foi alterada em 1.991, com a edição da primeira legislação acerca da matéria, que acabou por instituir o órgão regulador do mercado de capitais daquele país e criminalizar a figura do insider trading. Em 1.998 é feita uma primeira reforma na referida legislação, passando-se a prever penas de até dois

\footnotetext{
177 Artigo $380^{\circ}$-A do Código de Valores Mobiliários português

${ }^{178}$ Artigo $381^{\circ}$ do Código de Valores Mobiliários português

179 Artigos $388^{\circ}$ e seguintes do Código de Valores Mobiliários português. Acerca do tema, vide: PINTO, Frederico de Lacerda da Costa. O novo regime de crimes e contra-ordenações no código dos valores mobiliários. Coimbra: Almedina, 2000, p. 23 e ss.

${ }^{180}$ Artigo 161 do Código Penal Suíço

${ }^{181}$ Op. cit., p. 122-126

182 PROENÇA, José Marcelo Martins. Op. cit., p. 256-258. Segundo o autor, o sistema alemão de regulação do Mercado de Capitais surge em 1.970, e tem como característica principal a auto-regulação por parte dos participantes do mercado, assentado em prescrições éticas e regras corporativas, situação que foi alterada apenas em 1.994, seguindo as determinações da Diretiva 89/592, cuja aprovação, diga-se, sofreu forte resistência por parte das autoridades tedescas. (p. 256-257)
} 
anos de prisão e multa de vinte milhões de liras para o crime de uso indevido de informação privilegiada. ${ }^{183} \mathrm{O}$ ano de 2.005 marca a edição de duas reformas quanto ao regramento italiano. Em 18 de abril, insere-se o tipo da manipulação de mercado, com pena prevista de reclusão de um a seis anos e multa de vinte mil a três milhões de euros ${ }^{184}$ tal pena passou a ser cominada também ao crime de insider trading -, sendo que em dezembro do mesmo ano, por força de nova lei, referidas penas são dobradas, ${ }^{185}$ sistema que prevalece até os dias atuais.

Alterações como a verificada na legislação italiana são reflexo da edição da Diretiva 2003/6/CE do Parlamento Europeu, relativa ao abuso de informação privilegiada e à manipulação de mercado que, dentre outros preceitos, tratou de delimitar os conceitos aplicáveis às condutas puníveis, demonstrando grande preocupação com relação à existência e regulação de um eficiente mercado único de capitais.

Diante do exposto, vistos os principais fatores relacionados à uma expansão do direito penal no tocante à regulação do Mercado de Capitais, e feito um breve apanhado acerca do tratamento penal da matéria pelas principais legislações no exterior, cumpre uma análise detalhada da tutela penal no Brasil.

\footnotetext{
${ }^{183}$ Artigo 180 do Decreto Legislativo 24 febbraio 1998, n. 58

${ }^{184}$ Artigos 184 e 185 da Lei 18 aprile 2005, n. 62

${ }^{185}$ Artigo 39 da Lei 28 dicembre 2005, n. 262
} 


\section{A TUTELA PENAL DOS MERCADOS NO BRASIL}

\subsection{Bem jurídico protegido ou simples normatização?}

Trata-se de ponto central na presente dissertação, momento em que se procurará definir o bem juridicamente tutelado nos crimes contra o Mercado de Capitais, ante uma preocupação em estabelecer um referente material limitador da intervenção penal do Estado, evitando-se, assim, uma mera normativização da matéria.

\subsubsection{Evolução histórica e crise do conceito de bem jurídico: breves apontamentos}

As raízes do conceito de bem jurídico remontam ao período do Iluminismo, época na qual se procurou, com o fim de combater a arbitrariedade do aparato criminal, estabelecer limites ao direito de punir do Estado. ${ }^{186}$

Segundo Anselm Feuerbach, tais limites se encontrariam em um conceito material de delito, consistente sempre na lesão a um direito subjetivo. Dessa forma, a tutela penal estaria fundamentada em três pressupostos: existência de um direito subjetivo, danosidade social e necessidade de pena. ${ }^{187}$

Tal concepção, todavia, está limitada à existência de um direito subjetivo, o que nem sempre reflete uma realidade valorada pelo legislador como digna de garantia penal, como, por exemplo, nos delitos relativos à economia e à saúde pública.

\footnotetext{
${ }^{186}$ Como bem aponta Renato de Mello Jorge Silveira: "No período anterior à ilustração, o qual teve como expoente primeiro Beccaria, vivia o Direito Penal verdadeira situação anárquica, com definições do delito feitas de forma indeterminada." (Op. cit., p. 37). Cumpre aqui assinalar a posição de Roxin quanto ao tema: "[...] la cuestión de si el concepto de bien jurídico, cuyo creador se considera a Birnbaum, tenía ya en la época en que surgió en el siglo XIX un contenido liberal y limitador de la punibilidad, es tan discutida como la conexión que frecuentemente se afirma que existe entre la teoría del bien jurídico y el Derecho penal de la Ilustración, que se había esforzado por restringir la punibilidad a los 'danos sociales', derivando también de ello ya la exigencia de impunidad de las meras infracciones contra la moral. Sin embargo, esto no es lo que importa en este contexto, dado que en todo caso el concepto de bien jurídico ha asumido esa función en la moderna discusión sobre la reforma, con la que ha de enlazar la discusión actual”. (ROXIN, Claus. Derecho penal ... Op. cit., p. 55)

${ }^{187}$ CUNHA, Maria da Conceição Ferreira da. Constituição e crime: uma perspectiva da criminalizção e da descriminalização. Porto: Universidade Católica Portuguesa, 1995, p. 32
} 
Note-se, contudo, que a concepção de Feuerbach acaba por dotar o conceito de bem jurídico com eficácia prática, ao exercer uma função limitadora do poder legislativo com o estabelecimento de um conceito material de delito, o que, para Hormazábal Malarée, reflete uma influência da teoria do contrato social no direito penal. ${ }^{188}$

A Birnbaum, ${ }^{189}$ por sua vez, é atribuída a paternidade da teoria jurídicopenal do bem jurídico. Segundo referido autor, em obra datada de 1.834, o delito não lesionaria direitos subjetivos; mas sim bens estabelecidos em relação com uma pessoa que deles é titular, classificados como "naturais" (dados ao homem pela natureza das coisas) e "sociais" (resultado da evolução social). Dessa forma, a determinação do merecimento de tutela penal de um determinado objeto será sempre dependente da valoração dada pelo legislador.

No entender de Hormazábal Malarée, a concepção de Birnbaum não institui limites ao poder punitivo do Estado, aparecendo como instrumento restaurativo estatal, permitindo a incriminação de condutas perturbadoras das condições sociais da restauração. ${ }^{190}$

Para uma concepção positivista, por seu turno, o delito constituía a lesão de um direito subjetivo do Estado, direito de mandar e ser obedecido. Tal concepção, todavia, falha ao não diferenciar os delitos de outras infrações administrativas. Para resolver tal questão, busca Binding, no que seria o fim da norma, os objetos da imediata necessidade da pena, os quais denomina bens jurídicos, definindo-os como tudo o que em si mesmo não é um direito, mas que aos olhos do legislador é de valor como condição da vida sã da comunidade jurídica, em cuja manutenção incólume e livre de perturbações tem ela, segundo seu pensamento, interesse, de forma que procura com suas normas defender-se da não desejada lesão ou perigo. ${ }^{191}$

\footnotetext{
${ }^{188}$ Bien jurídico y estado social y democrático de derecho: el objecto protegido por la norma penal. Barcelona: PPU, 1991, p. 13).

189 "Birnbaum vai explicar o fato de ser decisiva, para a tutela penal, a existência de um bem fixado diretamente no mundo do ser ou da realidade (objeto material), de importância, este, para a pessoa ou para a coletividade, podendo se lesionado por uma ação delitiva." SILVEIRA, Renato de Mello Jorge. Op. cit., p. 40 ${ }^{190}$ Op. cit., p. 32

${ }^{191}$ Compendio di diritto penale: parte generale, p. 198
} 
Conforme se verifica, segundo a concepção de Binding, o indivíduo encontra-se ainda totalmente submisso ao Estado, não possuindo o bem jurídico conteúdo limitador do direito de punir, pelo que se pode concluir que o bem jurídico cumpre uma função de legitimação do poder coativo, podendo chegar a cobrir com um manto de legalidade a arbitrariedade estatal. ${ }^{192}$

Ainda dentro de uma concepção positivista, mas com fundo naturalísticosociológico, Von Liszt diverge de Binding, ao ter por verdade que o bem jurídico não é "bem do Direito" ou da ordem jurídica, mas um bem do homem, que o Direito reconhece e protege, numa concepção muito mais ampla do que o fazia o direito subjetivo. ${ }^{193} \mathrm{O}$ autor parte do pressuposto de que o Direito existe pela vontade humana, sendo o fim de todo o Direito Penal a proteção de interesses humanos vitais (interesses jurídicos). ${ }^{194}$ Verifica-se, pois, no pensamento de Von Liszt, influência do positivismo científico e do liberalismo progressista, pelo qual se valorizou a idéia de fim no Direito Penal. ${ }^{195}$

A partir da revolução burguesa, em fins do século XIX, início do século XX, dá-se uma revalorização dos ideais iluministas, como reação à certeza científica das chamadas "leis naturais" do pensamento positivista, iniciando-se uma escalada que vem a retomar o relativismo do pensamento de Kant, denominada de neokantismo. ${ }^{196}$

É, nessa época, desenvolvida uma concepção metodológica, ou teleometodológica, do bem jurídico. Procedendo a uma espiritualização e normatização conceitual do bem jurídico, inicia-se com Honig, em 1.919, a idealização deste com a 'ratio' da norma, sendo de se considerar, pois, que ela não possui existência prévia à das

\footnotetext{
192 HORMAZÁBAL MALARÉE. Op. cit., p. 46

193 SILVEIRA, Renato Jorge de Mello. Direito penal supra-individual. São Paulo: Revista dos Tribunais. 2003, p. 46.

${ }^{194}$ Conforme apregoa Juarez Tavares: “A noção de bem jurídico como interesse juridicamente protegido é produto da idéia privatística dominante no século passado, que se intrometeu na formulação da teoria do injusto desde Von Jhering. Aqui o marco penal encontra suas delimitações no momento subjetivo, quer dizer, na materialização do exercício da capacidade de contratar por parte do sujeito, de modo que, protegendo-se o interesse, se concebe a vida social como uma resultante de pretensões individuais, as quais dependendo de sua importância se vêem amparadas pela norma de direito público. Há aqui, se bem que ingênua, uma idéia utilitarista da norma penal sobre a base de uma realidade. O interesse não é algo imaginário, é algo perceptível, assim, por exemplo, a manutenção da vida, da integridade corporal, do patrimônio e sua possibilidade de transmissão, da reputação como expressão da própria individualidade no seio da comunidade, etc.”. (Teoria do Injusto Penal, Belo Horizonte: Del Rey, 2000, p. 177)

${ }^{195}$ MUSCO, Enzo. Bene Giuridico e Tutela dell’honore. Milano: Giuffrè, 1974, p.8

${ }^{196}$ SILVEIRA. Op. cit., p. 46-47
} 
próprias prescrições penais, não se confundindo com os 'substratos da realidade em que os valores poderão assentar'. ${ }^{197}$

Percebe-se, pois, conforme acentua Hormazábal Malarée ${ }^{198}$, com relação ao bem jurídico no pensamento neokantiano, sua redução a funções meramente teleológicas e sua concepção como bem de cultura. ${ }^{199}$

Após a Segunda Guerra Mundial, dá-se uma revalorização do conceito de bem jurídico, com enfoque para a limitação do poder de punir do Estado, tal qual haviam feito Birnbaum e Von Liszt. Surgem, pois, duas vertentes de teorias: sociológicas e constitucionais.

A primeira corrente tem como principais expoentes Amelung, Hassemer e Jakobs.

Amelung, influenciado por Parsons e Luhman, vê o bem jurídico como uma disfunção sistêmica, isto é, entendida a sociedade como um complexo sistema de interações, cabendo ao Direito lhe conferir estabilidade. Dessa forma, quando uma conduta viola as funções distribuídas pelo Direito, este as reafirma por meio da sanção, com o fim de manter a confiança da sociedade na funcionalidade do sistema. Trabalha, pois, com um conceito de danosidade social, pré-jurídico e capaz de servir de orientação ao legislador. ${ }^{200}$

\footnotetext{
${ }^{197}$ Idem, p. 47

198 Op. cit., p. 63

199 Segundo Juarez Tavares: "Com o neokantismo, porém, se inaugura já uma outra fase de evolução política, onde a medida individual cede lugar a posições ou situações preferenciais. Elimina-se definitivamente o sujeito e se trabalha com a noção de totalidade, decorrente de um puro juízo normativo, aparentemente neutro, mas em geral, de perfil autoritário, que obtém seu coroamento com a definitiva substituição da noção material de bem, pelo de valores ético-sociais (ontologismo). Regressa-se a uma fase anterior a Christian Thomasius, confunde-se a proteção jurídica com a proteção moral, travestida agora, de valores ético-sociais, de conteúdo ontológico, quer dizer, retirados não de um ato de vontade individual, ou de vontade do legislador, mas de uma refinada elaboração mental daqueles que os descobriram e desbravaram. Com tal postura, a noção de bem jurídico perde substancialidade. A proteção de valores ético-sociais nada mais é do que a incriminação da anti-sociabilidade, daí não ser incoerente que seus adeptos venham a conceituar o bem jurídico como um estado social, ou seja, uma determinada ordem, que se impõe como bem vital do indivíduo e da comunidade. Não está distante desse enfoque a segura ponderação de Juarez Cirino dos Santos, seguida por Nilo Batista, de que no fundo, em uma sociedade dividida em classes, o direito penal está protegendo relações sociais, interesses, estados sociais ou valores escolhidos pelas classes dominantes, ainda que, sob o critério de sua universalidade, o que implica igualmente, por um lado, o fortalecimento do descrédito desse conceito como fundamento protetivo e por outro, a possibilidade de sua crítica social." (Op. cit., p. 177-178) ${ }^{200}$ CUNHA. Op. cit., p. 91
} 
O problema da concepção de Amelung, segundo aponta Renato de Mello Jorge Silveira, reside na dificuldade de definição do que vem a ser socialmente danoso, acabando por socorrer-se da definição positivista de bem jurídico. ${ }^{201}$

Hassemer, por sua vez, sustenta a imprescindibilidade da confirmação de uma danosidade social para legitimação da intervenção penal do Estado, considerando os bens jurídicos desde uma perspectiva político-criminal geral. Contudo, conforme assinala Renato Silveira, ${ }^{202}$ retomam-se os limites em relação ao critério da intervenção estatal, por onde perde o bem jurídico seu significado próprio. De toda sorte, tanto Hassemer quanto Amelung reiniciam os postulados de Von Liszt, estando aí o seu grande mérito.

A posição de Hassemer quanto ao bem jurídico, ao longo do tempo, se desenvolveu rumo à teoria pessoal do bem jurídico, segundo a qual o conceito de bem jurídico "se pronuncia claramente em um campo de tensão entre indivíduo, sociedade e Estado", assim, os bens jurídicos "são interesses humanos que requerem proteção penal', a indicar que "a proteção das instituições só pode chegar até o ponto em que é condição de possibilidade de proteção da pessoa". ${ }^{203}$

De outro lado, a corrente constitucional do bem jurídico, do qual se destaca o posicionamento de Roxin, para quem, partindo-se da concepção de Estado de Direito contida na Constituição alemã, os bens jurídicos são concebidos como condições valiosas em que se concretizam os pressupostos da vida em comum. ${ }^{204}$

Fiandaca descreve o raciocínio desenvolvido por Roxin da seguinte forma: A tese se articula segundo a seguinte cadência: 1) as finalidades de tutela do instrumento penalístico são determinadas em função das esferas de atividades que hoje competem ao

\footnotetext{
${ }^{201}$ Direito penal supra-individual. Op. cit., p. 48

${ }^{202}$ Idem, p. 49

${ }^{203}$ Lineamentos de una teoria personal del bien jurídico. Op. cit., p. 282, tradução nossa. E prossegue o autor alemão: "Este concepto, por cierto, tampoco está lleno de presupuestos como para poder deducir de él decisiones políticocriminales acerca del merecimiento de pena. Pero esto tampoco se puede esperar respecto de un concepto de bien juridico. En primer lugar, su importancia - al igual que la de otros conceptos jurídicos fundamentales, como el 'principio de culpabilidad' o el 'in dubio pro libertate' -, no reside en posibilitar deducciones more geométrico, sino en dar a las discusiones jurídicas determinada línea argumental, como es, en este caso, la concepción personal en la elección de los objetos de protección penal. En segundo lugar, el concepto de bien jurídico debe ser siempre lo suficientemente abierto como para permitir una decisión discrecional del legislador penal".

${ }^{204}$ HORMAZÁBAL MALARÉE. Op. cit., p. 122
} 
Estado; 2) o hodierno Estado democrático de direito, enquanto laico e fundado na soberania popular, não pode perseguir o aperfeiçoamento moral dos cidadãos adultos, mas deve limitar-se a assegurar as condições de uma convivência pacífica; 3) o direito penal, ao fornecer seu contributo em tal direção, deve antes de tudo garantir os bens jurídicos fundamentais que estão sob os olhos de todos, como a vida, a integridade física, a liberdade, o patrimônio, etc. ${ }^{205}$

Ainda segundo Roxin, um conceito de bem jurídico político-criminalmente vinculante só pode derivar das incumbências do Estado de Direito, baseado na liberdade do indivíduo, estabelecidas na Constituição. Nesse sentido, bens jurídicos seriam as circunstâncias dadas ou finalidades que são úteis para o indivíduo e seu livre desenvolvimento no marco de um sistema social global estruturado sobre a base dessa concepção dos fins ou para o funcionamento do próprio sistema. ${ }^{206}$

Conclui o autor que o Direito Penal tem natureza subsidiária, e que o legislador não está autorizado a criminalizar condutas simplesmente imorais, recebendo o bem jurídico dupla proteção, "através do direito penal e ante o direito penal, cuja utilização exacerbada provoca precisamente as situações que pretende combater". ${ }^{207}$ Relevante, pois, a adoção de diretrizes de política criminal, como a priorização da assistência social e a utilização do Direito Penal como ultima ratio, apenas para proteger bens jurídicos essenciais.

Verifica-se, assim, que a doutrina do bem jurídico, buscando conferir limites materiais ao direito penal, estabeleceu que os tipos penais devem apresentar certo conteúdo material. Assim, para que possa proceder a criminalizações, deve o legislador estar diante de condutas que efetivamente lesionem ou coloquem em risco um bem jurídico-penal.

Entretanto, a doutrina do bem jurídico vem sendo veementemente contestada na atualidade por alguns autores, dentre eles Jakobs, que afirmam não fornecer

\footnotetext{
${ }^{205}$ FIANDACA, Giovanni. Il "bene giuridico" come problema teórico e come critério di política criminale. Rivista Italiana di Diritto e Procedura Penale, 1982, p. 46

${ }^{206}$ Derecho Penal: parte general - Fundamentos. La estructura de la teoría del delito, p. 56

${ }^{207}$ Problemas fundamentais de direito penal. Trad. Ana Paula dos Santos Luis Natscheradetz. Lisboa: Veja. 1981, p. 28.
} 
ela qualquer limitação efetiva ao direito penal, sugerindo seu abandono. Como conseqüência, os conteúdos materiais do direito penal não sofreriam mais uma limitação jurídica, consistente na idéia do bem jurídico, mas tão-somente a política, decorrente da situação e dos interesses sociais presentes num determinado momento e de sua influência sobre a esfera política. Para os adeptos dessa linha, a mera positivação ou normatização, formalmente perfeita, já seria suficiente para a criação de uma norma penal legítima. ${ }^{208}$ Dessa forma, Jakobs coloca a questão da legitimação material do direito penal desde a perspectiva da vigência da norma, de maneira que o bem jurídico seria a resistência à usurpação das expectativas, ou seja, o direito penal protege a vigência do conteúdo da norma, e não bens jurídicos. ${ }^{209}$

${ }^{208}$ JAKOBS, Günther. ¿Qué protege el derecho penal: bienes jurídicos o la vigencia de la norma? In: CANCIO MELIÁ, Manuel. El sistema funcionalista del derecho penal. Lima: Grijley: Universidad de Piura, 2000. JAKOBS, Günther. Derecho Penal - parte general, fundamientos de la imputación.. $2^{\mathrm{a}}$ ed. Madrid: Marcial Pons, 1997

${ }^{209}$ Acerca do tema, vale ainda citar a posição conciliadora de Bernardo Feijóo Sánchez: "Desde una perspectiva estrictamente dogmática creo que es un error conceptual (por parte de ambos extremos de la discusión) considerar que la afirmación de que la pena protege normas es incompatible con la referencia a la protección de bienes jurídicos. Mediante la estabilización de las normas se cumple una función de protección de bienes previniendo su lesión o puesta en peligro a través de comportamientos antijurídicos. Lo que sucede es que, desde esta perspectiva, la pena sólo proporciona una seguridad cognitiva o empírica de bienes de forma mediata o indirecta ofereciendo seguridad normativa, es decir, mediante el mantenimiento de vigencia del orden jurídico. No puede - ni debe - hacerlo de otra manera. Esta afirmación es una obviedad si se parte de un concepto dogmático de bien jurídico inmanente al sistema jurídico; es dedir, los bienes jurídicos sólo son tales en la medida que están creados por las normas o, lo que es lo mismo, lo que denominamos bienes jurídicos son construcciones del sistema jurídico. Por esa razón existen bienes jurídicos sui generes como los denominados intermedios o espiritualizados (salud pública, seguridad colectiva, seguridad del tráfico, etc.) que es evidente que no son más que una construcción del sistema jurídico y que desde otras perspectivas teóricas plantean muchos problemas. [...] El principal problema de la dominante referencia al concepto de bien jurídico como elemento esencial de la teoría jurídica del delito y, en concreto, del injusto, reside en que pone demasiado énfasis en la afectación de bienes dejando de lado la necesaria referencia a la juridicidad. Lo decisivo para la existencia de un injusto penal penal y el único elemento común denominador de todos los injustos es la lesión de la juridicidad en el plano comunicativo de la intersujectividad en la medida en que las normas son esquemas de coordinación entre ámbitos de organización." (Derecho penal de la empresa e imputación objetiva. Madrid: Editorial Reus, 2007, p. 39-43). Ainda, sobre os chamados bens jurídicos espiritualizados, o posicionamento de Renato de Mello Jorge Silveira: " Toda a construção da noção de bem jurídico, bem como seu desenvolvimento em noção abstrata e, quiçá, espiritualizada, teve como base a idéia welzeniana de que este bem deveria ser tido como um valor ideal, enquanto que sua lesividade encontrar-se-ia em um plano ideal de vigência dos valores e das normas, mostrando-se, pois, comum desvalor da ação. Isso vem a ganhar maior destaque em momento posterior, onde se aceita a lesão ao bem jurídico não como uma realidade fática, mas como um valor abstrato ou ideal a ser espiritualizado, conforme a denominação que se dê. [...] É certo que a idéia do bem jurídico espiritualizado vem a explicar muitas das novas feições do objeto de proteção. Embora uma linha clássica de pensar possa criticar tal embasamento, várias são as suas vantagens. Crítica irrespondível e incontestável diz respeito ao fato de que, não raro, com isso acaba por não se estabelecer a percepção com relação ao potencial dano ao bem jurídico, o que implica em dificuldade para aplicação da lei penal. De toda sorte, mostra-se tal concepção largamente difundida e aceita como meio explicativo ao uso dos crimes de perigo, sendo certo que, em conjunto com outros conteúdos dogmáticos, como é o caso da imputação objetiva, pode bem servir ao contexto geral da proteção penal econômica. (Direito penal econômico como direito penal de perigo. Op. cit., p. 151-154) 
O próprio Roxin, em sua última atualização da obra Direito Penal - Parte

Geral (2006), chega a relativizar o conceito de bem jurídico especificamente para determinadas situações, como a proteção de embriões, a tutela de plantas e animais e a proteção da vida das próximas gerações. ${ }^{210}$ Tal posição, todavia, não representou, na obra do autor, a superação total do conceito bem jurídico:

Também penso que os maus tratos a animais ou a extinção de espécies podem ser apenados, tal como, por exemplo, a destruição do clima que prejudique de forma duradoura a vida das gerações futuras, o que parece contradizer a idéia de proteção de bens jurídicos, pois o que se faça aos animais ou às gerações futuras não tem porque prejudicar às pessoas atualmente vivas. Todavia não há que se renunciar ao principio de proteção aos bens jurídicos, como pretende Stratenwerth, mas apenas ampliá-lo, estendendo o contrato social do círculo das pessoas viventes a outras criaturas da criação [Mitgeschopfe] e às gerações futuras. ${ }^{211}$

\footnotetext{
${ }^{210}$ Nesse sentido, Helena Regina Lobo da Costa: "Roxin, na mais recente edição de sua obra Direito Penal Parte Geral, admite a possibilidade de um alargamento do âmbito do direito penal para além da proteção de bens jurídicos. O autor não abandona por completo o conceito de bem jurídico, mas defende que ele não mais se ajusta às características dos tempos atuais, devendo-se, pois, admitir o uso do direito penal para as seguintes esferas:, em que não há bem jurídico: proteção de embriões, proteção de plantas e animais, e proteção da vida das próximas gerações."'(Proteção ambiental, direto penal e direito administrativo. Tese de doutoramento apresentada à Faculdade de Direito da Universidade de São Paulo em 2007, p. 18)

${ }^{211}$ Tradução livre. ROXIN, Claus. ¿Es la protección de bienes jurídicos una finalidad del Derecho Penal? Trad. Inigo Ortiz de Urbina Gimeno. In: HEFENDEHL, Roland (ed.). La teoria del bien jurídico. Madrid: Marcial Pons, 2007, p. 456. Acerca do tema, vale também citar Hefendhel, que sintetiza o pensamento de Roxin, justificando a transcrição do seguinte trecho: "Roxin ha expressado de nuevo con gran claridad el significado del principio del bien jurídico em la nueva edición de 2006 del primer tomo de su tratado, de forma significativamente ampliada en comparación com la tercera edicion del año de 1997. Un punto central de su posicion lo constituye - tal y como también sostengo - la función de delimitación negativa. En este sentido, menciona no menos que nueve constelaciones em las cuales no se trata de la protección de bienes jurídicos: leyes arbitrarias, motivadas sólo ideológicamente o vulneradoras de derechos fundamentales; trasnscripciones de las finalidades legislativas; aquello contrario a la moral, la ética y otras condutas reprobables; vulneraciones de la propia dignidad o de la dignidad del ser humano; protección de sentimientos; la autolesión consciente, possibilitarla o auxiliarla; normas penales principalmente simbólicas; tabúes; objetos de protección de uma abstración incompensible. Roxin también hace el intento de definir positivamente el concepto de bien jurídico: bajo el concepto de bien jurídico han de comprenderse todas las circunstancias o finalidades necesarias para el libre desarollo de los indivíduos, la realización de sus derechos fundamentales y el funcionamiento de um sistema estatal basado em esas finalidades. Sin embargo, se vé rápidamente que no pueden ser más que grandes directrices - pinceladas al fresco - cuyo potencial constructivo o crítico es menor. [...] Finalmente Roxin menciona el campo de la protección de embriones, animales y de la naturaleza así como de la vida de generaciones futuras como ámbitos en los cuales el principio de protección de bienes jurídicos no es de ayuda, pero que deben ser aceptados por um Derecho Penal moderno. Com ello se abandona, por lo menos, el camino equivocado de querer, a pesar de todo, construir um bien jurídicoen el caso de la protección de los animales o la naturaleza. Así lo habia formulado Roxin em la edición previa: '... hay que partir de la base de que el legislador, em una especie de solidaridad entre las criaturas tambíen considera a los animales superiores como nuestros semejantes, como hermanos distintos, y los protege como tales'. En lo que atane a la exigência de ampliación del concepto de protección de bienes jurídicos a la vida de generaciones futuras, Roxin va, innecesariamente em mi opinión, demasiado lejos en cuanto a la idea, ya que com ello se refiere a la protección penal del medio ambiente, a la cual han de sumarse de todas formas bienes jurídicos también con relevância futura. Uno de los autores a los que recurre Roxin como cita de autoridad - Stratenwerth - se há desecho totalmente ya de las ataduras del pensamiento del bien jurídico, lo cual también Roxin contempla con escepticismo. El otro - Schunemann exige desde hace mucho tiempo la renuncia a la accesoriedad administrativa, puesto que, de lo contrario, no parece realizable em caso alguno la protección acológicamente acentuada del futuro de la humanidad que
} 
Há, ainda, grande discussão acerca da configuração de bens jurídicos coletivos ou difusos. ${ }^{212}$

Tal debate é decorrência lógica do movimento de expansão do Direito Penal observado desde meados do século XX, com o surgimento de novos conflitos sociais geradores, por conseqüência, de riscos penais até então desconhecidos, tendo como resultado a criminalização de inúmeras condutas, especialmente aquelas ligadas à atividade econômica, às quais nem sempre se poderá atribuir um sujeito passivo determinado. ${ }^{213}$

A discussão que se instala a partir da criação de tais bens jurídicos supraindividuais traz à baila valioso debate quanto à validade da criação de tais bens jurídicos, vistos em contraposição aos princípios do direito penal clássico, como a lesividade, intervenção mínima, fragmentariedade e subsidiariedade. ${ }^{214}$

Para Susana Soto Navarro, tais críticas se atém muito mais aos defeitos do processo de criação legislativo, e demonstram excessivo apego a uma concepção liberal,

propone. Roxin, por el contrario, no quiere renunciar al principio de protección de bienes jurídicos, sino sólo verlo ampliado, pero no explica cómo debe ser esa ampliación, si es que no quiere seguir a Schunemann. (HEFENDEHL, Roland. De largo aliento: el concepto de bien jurídico. Trad. Gonzalo Medina Schulz. In: HEFENDEHL, Roland (ed.). La teoria del bien jurídico. Madrid: Marcial Pons, 2007, p. 463 - 469). Helena Regina Lobo da Costa aponta ainda dentro desta corrente de abandono do bem jurídico Günther Stratenwerth, para quem, "ao analisar o uso do direito penal na contenção de riscos futuros, afirma que pouco sobra da função limitadora do bem jurídico quando se consideram as bases vitais naturais do ser humano como bem jurídico, já que ninguém consegue dizer o que está contido nesta idéia. Por essa razão, o autor propõe a substituição da noção de bem jurídico pela de relações da vida como tais (Lebenszusammenhange als solche)”. (Op. cit., p. 18, tradução nossa)

${ }^{212}$ Conforme aponta Luiz Régis Prado: “A essa categoria de bens jurídicos, chamados metaindividuais, a doutrina tem apresentado as mais diversas denominações, conceitos e classificações. São eles uma realidade inegável, ainda que de difícil identificação e com conteúdo muitas vezes ambíguo, e que bem por isso escapam a uma definição mais exata. Denominados genericamente como bens jurídicos universais, macrossociais, supra-individuais, metaindividuais ou transindividuais, apresentam inúmeras características que permitem conceituá-los ou classificá-los conforme sua predominância ou a perspectiva com que são vistos ou analisados". (Bem jurídico-penal e constituição. 3. ed. rev. e atual. São Paulo: Ed. Revista dos Tribunais, 2.003, p. 106)

${ }^{213}$ Conforme assevera Renato Silveira: “[...] essas novas criminalizações, presentes nos últimos anos, e os projetos de lei para um futuro próximo têm um denominador comum: introduzem novos bens jurídicos difusos ou reforçam a tutela dos bens que, por um adequado conceito de bem jurídico, resultam muito vagos: crimes tributários, crimes na formação de balanços, na utilização de subvenções, contra o ambiente, em matéria de calculadoras eletrônicas e de estupefacientes." (Direito penal supra-individual. Op. cit., p. 67)

${ }^{214}$ Acerca dos princípios do bem jurídico, vide: SILVEIRA, Renato de Mello Jorge. Idem, p. 54-56 
totalmente oposta ao protagonismo estatal e sua incidência junto à infra-estrutura econômica. $^{215}$

Segundo a autora espanhola, tais bens jurídicos supra-individuais são dotados de quatro características principais, a saber: titularidade compartilhada, indisponibilidade, indivisibilidade e natureza conflitual. São as duas primeiras características, para esta, muito mais uma consequência do que fundamento ou o rasgo constitutivo dos bens jurídicos supra-individuais. Nesse diapasão, o principal elemento definidor da natureza supra-individual de um bem jurídico reside na sua indivisibilidade ${ }^{216}$. Para tanto, parte do conceito formulado por Hefendehl: "um bem será coletivo quando for conceitual, fática ou juridicamente impossível dividir tal bem em partes e atribuí-las de forma individual em tantas porções.",217

Pierpaolo Cruz Bottini, por sua vez, seguindo os preceitos da teoria pessoal do bem jurídico, consoante defendido por Hassemer, ${ }^{218}$ advoga uma funcionalização do direito penal, sendo a função precípua deste em um Estado Democrático de Direito, a proteção da dignidade humana, "consubstanciada na tutela de bens e interesses essenciais para sua materialização". ${ }^{219}$ Segundo o autor, a legitimidade e os limites do direito penal decorrem da garantia de existência segura de bens jurídicos, primando pelo atrelamento entre os conceitos de bem jurídico e dignidade humana, especialmente no âmbito de uma

\footnotetext{
${ }^{215}$ La proteción penal de los bienes colectivos em la sociedad moderna. Granada: Comares, 2003, p. 171 e ss.

216 " [...] los bienes que pertenecen de forma indivisa a un colectivo de personas son, por naturaleza, indisponibles de forma unilateral; em cambio, no todos los bienes divisibles en intereses individuales son por ello de libre disposición. Se trata, por tanto, de un criterio diferenciador y constitutivo, que cobra particular importância en ciertos âmbitos de protección penal en los que formalmente se reconoce un bien jurídico de naturalez colectiva, cuando en realidad se puede descomponer en una pluralidad de intereses individuales homogêneos o no.En tales supuestos, la afirmación de un bien jurídico colectivo sólo aporta confusión, porque el verdadero problema no reside, a mi juicio, en la identificación de los intereses lesionables sino en la modalidad de ataque a los mismos, caracterizada por su potencial ofensivo frente a una pluralidad indeterminada de sujetos pasivos." (Idem, p. 199).

${ }^{217}$ Tradução nossa do original: "[...] un bien jurídico será colectivo "cuando sea conceptual, fáctica o juridicamente imposible dividir tal bien en partes y atribuirlas de forma individual em tanto porciones"”. (HEFENDHEL, Roland, in apud. SOTO NAVARRO, Susana. Op. cit., p. 198-199)

218 “[...] un concepto personal del bien jurídico no rechaza la posibilidad de bienes jurídicos generales o estatales, pero funcionaliza estos bienes desde la persona: solamente puede aceptarlos con la condición de que brinden la posibilidad de servir a intereses del hombre". (HASSEMER, Winfried. Lineamentos de una teoria personal del bien jurídico. Op. cit., p. 282). No mesmo sentido: STERNBERG-LIEBEN, Detlev. Bien jurídico, proporcionalidad y libertad del legislador penal. Trad. Íñigo Ortiz de Urbina Gimeno. In: HEFENDEHL, Roland (ed.). La teoria del bien jurídico. Madrid: Marcial Pons, 2007, p. 109

${ }^{219}$ Op. cit., p. $175-178$
} 
sociedade de risco, funcionando a proteção de bens jurídicos como fator de limitação à expansão do direito penal. ${ }^{220}$

No tocante aos chamados interesses supra-individuais, Pierpaolo Bottini alerta para o risco de sua elevação à categoria de bens juridicamente protegidos poder levar à dissolução do próprio conceito de bem jurídico. ${ }^{221}$ Para este, a fluidez do conceito de bem jurídico pode possibilitar a elevação de qualquer interesse a merecer tutela penal, o que acaba por desnaturar completamente a função do bem jurídico, que passará a justificar a atuação repressora do Estado e não limitá-la.

Como solução - posicionamento adotado no presente trabalho -, o autor propõe a recuperação da capacidade crítica do conceito de bem jurídico, a fím de que tais bens supra-individuais sejam compreendidos como "contextos necessários para, ainda que de maneira mediata, garantir a existência de interesses individuais indispensáveis para a materialização da dignidade humana". Dessa forma, tais bens jurídicos acabam por refletir "as condições necessárias ou o meio seguro para o livre exercício dos interesses individuais". 222

Nesse sentido, vale transcrever o posicionamento de Juarez Tavares:

Ainda que se possa reconhecer a existência de um bem jurídico estatal ou coletivo, sua inserção como tal não desnatura o conteúdo estritamente pessoal desses bens. O interesse fiscal do Estado, por exemplo, não pode ser erigido em bem jurídico unicamente por causa dos interesses do poder público, mas sempre como condição de sobrevivência ou de melhoria da vida da pessoa humana, o que induz constantemente à discussão em torno da legitimação de todas as incriminações daí derivadas. ${ }^{223}$

\footnotetext{
${ }^{220}$ Para o autor, "[...] bem jurídico será todo elemento indispensável ao livre desenvolvimento do indivíduo dentro de um sistema social orientado para a autodeterminação, para a garantia da pluralidade e da liberdade democrática". (Idem, p. 176)

221 “[...] a excessiva abstração dos interesses difusos impede sua delimitação clara e, conseqüentemente, sua utilidade como instrumento de limitação do direito penal, a ponto de setores da doutrina afirmarem que o objeto de proteção do direito penal não são bens jurídicos, mas normas de organização, expectativas de comportamentos ou proteção de padrões de segurança que evitem perturbações sociais. Esta desvinculação da norma penal do conceito de bem jurídico acarreta a tendência, observada atualmente na prática políticocriminal, de utilização do direito penal como mero reforço das normas administrativas sancionadoras." (Idem, p. 180-181)

${ }^{222}$ Idem, p. 183. E prossegue: "Isso não significa definir bens transindividuais como mero somatório dos bens jurídicos individuais. O conteúdo de proteção de ambos é substancialmente diferente porque aqueles, quando afetados, em geral não permitem a aferição de prejuízos perfeitamente individualizáveis, pois não se pode quantificar a parcela que pertence a cada indivíduo em relação ao todo."

${ }^{223}$ Op. cit., p. 203
} 
Renato de Mello Jorge Silveira segue na mesma esteira de entendimento:

[...] fazer-se referência a valores sem uma recíproca exigência de que sua infração suponha uma repercussão negativa nos indivíduos como seres sociais é por demais criticável. A legitimidade da proteção desses bens jurídicos sempre é de ser mantida, desde que eles se lastrem nos interesses fundamentais da vida social da pessoa. [...] a distinção realizada quanto às pessoas, determinadas ou indeterminadas, de um certo grupo, perderá a razão de ser ao se tomar a necessidade de que, mesmo dentro de uma massa indistinta de pessoas, alguns agentes tenham de ser identificados para poder-se configurar uma lesão ou, ao menos, um prognóstico de lesão a um bem penalmente protegido. ${ }^{224}$

A referência antropocêntrica se faz, assim, necessária para a configuração de interesses supra-individuais como bens penalmente tuteláveis, e, ainda que não tão evidente, imprescindível se faz uma investigação mediata e teleológica.

Outro ponto central na discussão acerca da tutela penal de bens supraindividuais diz respeito à utilização de crimes de perigo abstrato, cuja aceitação está longe de ser unânime pela doutrina; mas que representa atualmente grande parcela das soluções adotadas pelo legislador frente aos riscos penais da modernidade, como, por exemplo, nos crimes contra o meio ambiente e as relações de consumo. ${ }^{225}$

A adoção de crimes de perigo abstrato tem sido defendida por parte dos doutrinadores brasileiros, ${ }^{226}$ como meio adequado à tutela penal de bens jurídicos supraindividuais. Defende-se, via de regra, que por meio das formulações de perigo abstrato, ao se abandonar a exigência de um resultado de dano ou de perigo concreto, restaria resolvida

\footnotetext{
${ }^{224}$ Direito penal supra-individual. Op. cit., p. 57-59. No mesmo sentido: “[...] no modelo de Estado adotado pela Constituição, a sanção penal, interferindo diretamente com a dignidade e os direitos fundamentais da pessoa humana, somente pode ter como fundamento a proteção das condições essenciais à garantia e implementação desses mesmos valores, ou seja, bens jurídico-penais. Essa consideração de um valor ou bem como condição essencial à garantia e implementação da dignidade e dos direitos fundamentais da pessoa humana é que vai fundamentar, num primeiro momento, o juízo acerca do merecimento de pena e, pois, acerca da qualificação de um bem ou valor como bem jurídico-penal". (ESTELLITA, Heloisa. A tutela penal e as obrigações tributárias na Constituição Federal.São Paulo: Revista dos Tribunais, 2001, p. 220)

${ }^{225}$ Conforme leciona Miguel Reale Júnior: "Em certos tipos penais o legislador presume a periculosidade da situação, mesmo que efetivamente nenhuma periculosidade tenha concretamente derivado a algum bem jurídico, bastando a realização da ação, considerando-se inerente a esta a periculosidade, tendo em vista aquilo que em geral decorre da experiência normal. No crime de perigo abstrato o legislador adstrito à realidade e à experiência torna puníveis ações que atendida a natureza das coisas trazem ínsito um perigo ao objeto da tutela.”. (Instituições de Direito Penal. Op. cit., p. 279)
} 
tanto a adequação do tipo penal à proteção de interesses meta-individuais; como também facilitadas eventuais dificuldades de imputação e de prova.

Todavia, tais formulações de perigo abstrato devem ser vistas com o devido cuidado, posto que, por vezes, acabam por refletir, por parte do legislador, a utilização de cláusulas gerais, quando em muitas das situações é possível prever e determinar quais condutas efetivamente perigosas afrontam o bem juridicamente tutelado. ${ }^{227}$

Nesse sentido tem especial papel o princípio da lesividade, a exigir uma efetiva lesão a um bem para justificar sua proteção. ${ }^{228}$ Tal idéia pode parecer contraditória à própria noção de perigo abstrato, mas aparente antinomia é bem resolvida por Renato de Mello Jorge Silveira:

Apesar de todas as críticas quanto à ilegitimidade constitucional de um chamado perigo presumido, como o faz Giusino, a justificativa pleiteada reside em uma observação da lesividade para sua configuração como fato penalmente relevante. Isso não significa dar um ar de expressa concretude ao perigo abstrato, mas sim reconhecer, na técnica legislativa de tipificação penal, uma mais perceptível possibilidade de perigo a um dado fato. Vale dizer, a redação do tipo penal deve, claramente, denotar a lesividade potencial da conduta reprovável. Trata-se, enfim, de uma legitimação dos crimes de perigo abstrato fundada em melhor técnica legislativa de construção, ou em uma carga semântica que autoriza a punibilidade. $^{229}$

O autor, contudo, impõe relevante ressalva:

Isso, no entanto, apesar de parecer referendar algumas aplicações do perigo abstrato, colide, ainda e sempre, com a noção de lesividade. Não se bem colocando a questão do bem jurídico protegido, poderá ocorrer a existência de casos em que a injustiça fática se mostre imperante. A

${ }^{226}$ COSTA JR., Paulo José da. Direito Penal ecológico. Rio de Janeiro: Forense Universitária, 1996, p. 75. PRADO, Luiz Régis. Direito Penal ambiental: problemas fundamentais. São Paulo: Ed. Revista dos Tribunais, 1992, p. 76

${ }^{227}$ Miguel Reale Júnior cita como exemplo o crime de gestão temerária, previsto no art. $4^{\text {o }}$, da Lei 7.492/86. (Instituições .... Op. cit., p. 279)

${ }^{228}$ Conforme SILVEIRA, Renato de Mello Jorge. Direito penal supra-individual. Op. cit., p. 54. E também: "a norma penal somente será legítima se tutelar um interesse fundamental do ser humano. Para materializar essa assertiva e conferir-lhe operacionalidade, surge o principio da lesividade. O conceito de nullum crimen sine iniuria estabelece que somente será penalmente relevante a conduta que lesiona o bem jurídico protegido, de forma que serão atípicos os atos que não afetem os interesses tutelados. [...] o princípio dalesividade somente cumpre com sua função de limitação do poder punitivo se estiver atrelado ao conceito de bem jurídico já defendido, ou seja, a um interesse, individual ou coletivo, que se refira, em última análise, à dignidade humana." (BOTTINI, Pierpaolo Cruz. Op. cit., p. 202-204)

${ }^{229}$ Direito penal econômico .... Op. cit., p. 157 
solução meramente legislativa, portanto, nem sempre resolve todos os problemas. $^{230}$

E conclui:

A busca constante por um referendar, de um lado, e uma legitimação de sua utilização, por outro, impelem a dogmática a nóveis enquadramentos doutrinários, utilizando-se de toda sorte de armas para uma nova construção do perigo. A percepção de uma quebra do próprio princípio da lesividade transmuta o que se tinha por mera abstração em uma constatação mais concreta e palpável. Nenhuma das construções mencionadas aclara situações duvidosas, as quais se revelam ainda presentes. Os parâmetros garantistas melhor indicam outra ordem de abordagem. O injusto, o desvalor da ação, do resultado e da perigosidade, aliados a técnicas de imputação objetiva, talvez melhor respondam a isso". [...] De toda forma, a clássica afirmação pela insuperabilidade e absoluta necessidade de uma proteção in abstrato parece, cada vez mais, ceder espaço para idéias mais apuradas. A fundamentação de uma proteção unicamente ratio legis não mais pode se dar ou aceitar. ${ }^{231}$

Vale também destacar a posição de Miguel Reale Júnior:

Concordo com Ângelo Ilha da Silva no sentido de que o perigo deve estar ínsito na conduta, segundo o revelado pela experiência, e não ser considerado presumido pelo legislador, mas adotando a sinomímia abstrato ou presumido, pois entendo que o perigo é presumido no sentido de que pode haver prova em contrário da inexistência do perigo, dandose uma presunção iuris tantum, sujeita a prova em contrário, pois só dessa forma se adequa a figura do perigo abstrato à exigência da lesividade, dentro de um direito penal garantista, quando se expande a criação de figuras de perigo abstrato na proteção de bens jurídicos universais, como o meio ambiente. ${ }^{232}$

Trata-se, pois, de tema dos mais espinhosos dentro do debate dogmático atual, e, a despeito de todas as críticas e dúvidas que se possa ter, não se pretende abandonar por completo a idéia da utilização dos crimes de perigo abstrato, especialmente no tocante à proteção de interesses supra-individuais. De fato, está entre os desafios do direito penal moderno a adoção de novos meios mais adequados ao enfrentamento dos riscos postos pela dinâmica da sociedade contemporânea. Não se pode, contudo, ignorar os preceitos basilares de ultima ratio e intervenção mínima, além, claro, da apregoada lesividade, sob pena de se trazer maior insegurança.

\footnotetext{
${ }^{230}$ Idem

${ }^{231}$ Idem, p. 158

${ }^{232}$ Instituições .... Op. cit., p. 279-280
} 
Retornando à discussão acerca da crise do bem jurídico, vale trazer à baila indagação recente de Andrew von Hirsch, no sentido de aproximar a teoria do princípio do dano, originária do direito anglo-saxão, à teoria do bem jurídico. ${ }^{233}$

Concebida nos sistemas legais anglo-saxônicos em meados do século XIX, a teoria do princípio do dano - harm principle - funciona como uma das bases de legitimação penal em tais sistemas.

Atribui-se ao filósofo John Stuart Mill a estruturação da teoria do princípio do dano, quando, em sua obra On Liberty, de 1.859, afirma que o único propósito pelo qual o poder pode ser legitimamente exercido contra um membro de uma sociedade civilizada reside na prevenção a danos contra terceiros. ${ }^{234}$

Tal teoria foi posteriormente desenvolvida pelo filósofo norte-americano Joel Feinberg, ${ }^{235}$ para o qual, segundo aponta von Hirsch, ${ }^{236}$ existe uma razão suficiente

\footnotetext{
${ }^{233}$ Nesse sentido, o autor alemão, em artigo recentemente traduzido ao espanhol, tenta analisar se da teoria anglo-americana pode-se extrair um conceito próximo ao de bem jurídico, e em que termos tal identificação pode contribuir para a ampla discussão atual acerca da validade do conceito de bem jurídico. Importante, contudo, ressalvar que o "princípio do dano" não exerce no direito anglo-saxão a função de bem jurídico, conceito inexistente em tal sistema penal. Vide: HIRSCH, Andrew von. El concepto de bien juridico y el "principio del daño". Trad. Gonzalo Medina Schulz. In: HEFENDEHL, Roland (ed.). La teoria del bien jurídico. Madrid: Marcial Pons, 2007, p. 37-52

${ }^{234}$ Tradução nossa de: "That the only purpose for wich power can be righfully exercised over any member of a civilised community, against his will, is to prevent harm to others." (MILL, John Stuart. On liberty, cap. $4^{\circ}$. Apud. HIRSCH, Andrew von. Op. Cit., p. 39 )

${ }^{235}$ Segundo o autor: "The criminal law is not the state's primary tool for the reduction of harms generaly. (...) But the criminal law system is the primary instrumentality for preventing people form intentionaly or recklessly harming one another. Acts of harming then are the direct objects of the criminal law, not simply states of harm as such. Form the legislative point of view, however, states of harm are fundamental, for they determine in part which acts are to count as acts of harming, and to become thereby proper targets of prohibitory legislation. An act of harming is one which causes harm to people. (...) The word 'harm' is both vague and ambiguous, so if we are to use the harm principle to good effect, we must especify more clearly how harm (harmed condition) is to be understood. In its bare formulation, without further explanation, the harm principle is a mere convenient abbreviation for a complicated statement that includes, among other things, moral judgments and value weightings of a variety of kinds." E prossegue: "But how great must the harm be in order for the harm principle to warrant legal coercion to prevent it? It goes without saying, of course, that the prooscribed actions must tend to cause genuine harm and not mere annoyance, inconvenience, hurt, or offense. But bare criminal invasions of interest just above the thersold of harm are not the appropriate objects of legal coercion either, and a plausible version of the harm principle must be qualified to exclude them." (FEINBERG, Joel. The moral limits of the criminal law. Harm to others. New York: Oxford University Press, 1986, vol. 1, p. 31-32 e 188)

${ }^{236}$ Segundo aponta o autor alemão: "El harm principle, criterio que también para Feinberg ocupa un lugar central, ha de estar orientado prioritariamente a asegurar las condiciones de la convivencia social, en cuanto los intereses primordiales del individuo son protegidos frente a injerencias externas, y ello de modo que intente asegurarse la mayor optimización posible de las esferas de libertad de todos. [...] Según la teoria de
} 
para a criminalização quando a conduta em questão é lesiva para outros (harmful to others), devendo ainda ser levada a cabo com dolo ou culpa. Tal princípio, para o filósofo norte-americano, funciona, dessa forma, como um princípio limitador da atuação punitiva estatal. $^{237}$

Hirsch aponta que uma derivação do bem jurídico a partir do harm principle poderia contribuir para o atual debate sobre o primeiro instituto, pois a definição de harm to others ${ }^{238}$ poderia ser um enfoque útil tanto para constituir como para limitar o conceito de bem jurídico. Nesse sentido, segundo o autor tedesco, a lesividade deve ser analisada desde uma ótica individualista, tratando-se de lesões a pessoas de "carne e osso". Observa ainda que o harm principle poderá abarcar condutas lesivas a bens jurídicos supraindividuais, exigindo, por outro lado, que a ratio de tais bens meta-individuais resida na tutela da qualidade de vida dos seres humanos, vale dizer, o prioritário são sempre os interesses pessoais. $^{239}$

Trata-se, pois, de uma tentativa de aproximação de conceitos do direito anglo-saxão à tradição romanística e que, a despeito da necessidade de uma investigação científica aprofundada - não comportada no presente estudo -, chega a ser muito próxima, ao menos quanto aos fins perseguidos, das propostas formuladas por Juarez Tavares e Pierpaolo Bottini, expostas anteriormente. ${ }^{240}$

Feinberg, para adquirir relevância penal una conducta sólo debe ser lesiva, sino además 'wrongful', al menos en el sentido de ser realizada con dolo o (en algunos casos) imprudencia. [...] Mientras que Mills limito su concepción esencialmente a las conductas dañosas, Feinberg considera que bajo determinadas circunstancias el riesgo de consecuencias lesivas puede equipararse al daño efectivo. Desde estas premisas, admite la criminalización de distintas formas de peligro abstracto. De acuerdo con Feinberg, las conductas que no causan un daño pueden ser prohibidas siempre que puedan dar lugar a consecuencias lesivas en un futuro, para cuya evaluación será determinante la probabilidad y la gravedad del eventual daño a producir." (Op. cit., p. 39)

${ }^{237}$ Hirsch, ao discorrer acerca da teoria de Feinberg, aponta ainda outros critérios de criminalização externos ao princípio do dano apontados pelo autor norte americano, aos quais não nos atemos por conta da extensão do presente trabalho. (Op. cit., p. $47-52$ )

238 "[...] una injerencia en los recursos de otra persona sobre los que ella tiene um derecho [...]". HIRSCH, Andrew von. Op cit., p. 44

${ }^{239}$ Idem, p. 44-45

${ }^{240}$ Vale transcrever as conclusões a que chega Hirsch no texto analisado, as quais, de toda sorte, apenas corroboram as dificuldades de se chegar a um conceito e função precisos para o instituto do bem jurídico: "Las similitudas puestas de manifesto en este trabajo entre la noción angloamericana de harm principle y el concepto alemán de bien jurídico permiten, a mi modo de ver, extraer algunos conocimientos instructivos acerca del fundamento y estructura del bien jurídico. Pero al mismo tiempo debría haber quedado claro que el bien jurídico por sí solo no puede conformar una teoría adecuada de la criminalización. Y la cuestión acerca 
Fato é que o conceito de bem jurídico está deveras longe de ser unanimemente definido, ${ }^{241}$ e a validade de sua atual aplicação ao Direito Penal, frente aos novos conflitos sociais impostos pela pós-modernidade, revela uma verdadeira situação de crise, abrindo margem ao questionamento acerca da real função, e quiçá, da validade do instituto.

De toda forma, a orientação dogmática que vincula o presente trabalho segue uma idéia de bem jurídico enquanto limitador da atuação estatal em matéria penal, sempre voltado à garantia da dignidade humana. ${ }^{242}$

Não se pode, ademais, prescindir de outros critérios balizadores da intervenção penal do Estado, externos ao bem jurídico, como a aplicação do princípio da proporcionalidade, consubstanciado em um juízo de adequação e necessidade, posto que, consoante afirma Hassemer, uma conduta que ameaça a um bem jurídico é condição necessária, mas não suficiente, para criminalizar esta conduta. ${ }^{243}$

Princípio de cunho constitucional, a proporcionalidade é, como assevera Ângelo Roberto Ilha da Silva, antes de mais nada, "uma imposição do Estado de Direito". ${ }^{244}$ Ulfrid Neumann o conceitua como verdadeira "proibição de excesso", vedando

de si deben existir criterios legítimos de criminalización más allá de la noción del bién jurídico, cuales habrían de ser y dónde habría de situar sus limites, dista mucho de estar resuelta". (Op. cit., p. 52).

${ }^{241}$ HEFENDEHL, Roland. El bien jurídico como eje material de la norma penal. Trad. María Martín Lorenzo. In: HEFENDEHL, Roland (ed.). La teoria del bien jurídico. Madrid: Marcial Pons, 2007, p. 180 e ss.

${ }^{242}$ Acerca do tema: [...] apesar das controvérsias relativas ao bem jurídico penal, desde os primórdios, tal instituto traz, em seu bojo, uma idéia de limitação, ou, pelo menos, de busca de limitação ao poder de punir do Estado; prova dessa análise constitui o rechaço que se tem feito às teorias funcionalistas radicais, que justamente por prescindirem da tutela a bens jurídicos são considerados, como visto, potencialmente arbitrárias e totalitárias. Cumpre consignar que o caráter limitador do bem jurídico fica expresso quando analisados os princípios informadores d Direito Penal mínimo (subsidiariedade, fragmentariedade e lesividade), segundo os quais nem tudo pode ser considerado bem jurídico penal". (PASCHOAL, Janaina Conceição. Constituição, Criminalização e Direito Penal Mínimo. São Paulo: Revista dos Tribunais, 2.003, p. 48) Ainda quanto a uma abordagem constitucional do bem jurídico, vale citar a posição de Luiz Régis Prado: Para selecionar o que deve ou não merecer a proteção da lei penal - bem jurídico -, o legislador ordinário deve necessariamente levar em conta os princípios penais que são as vigas mestras - fundantes e regentes - de todo o ordenamento penal. Esses princípios, que se encontram em sua maioria albergados, de forma explícita ou implícita, no texto constitucional, formam por assim dizer o núcleo gravitacional, o ser constitutivo do Direito Penal. (Op. cit., p. 66)

${ }^{243} \mathrm{O}$ autor alemão aponta pela necessidade de conjugação dos princípios orientados à limitação da punibilidade, os quais resume em um conceito que denomina "formalização da administração da justiça". Tais princípios são: subsidiariedade, danosidade social, tolerância, humanidade e proteção da dignidade humana.(Teoría personal del bien jurídico. Op. cit., p. 278)

${ }^{244}$ Dos crimes de perigo abstrato em face da Constituição. São Paulo: Revista dos Tribunais, 2003, p. 102. 
que recaia sob o indivíduo "ônus que são, quanto aos objetivos perseguidos, em sentido instrumental, desnecessários e, sob aspectos normativos, inadequados”. ${ }^{245}$

Quanto à aferição da adequação de intervenção penal do Estado, primeiro dos aspectos encontrados no princípio da proporcionalidade, trata-se de verificar se a norma penal tem idoneidade para os fins propostos, representando um juízo negativo, consoante observa Ângelo Roberto Ilha da Silva, ${ }^{246}$ "apenas quando a medida restritiva se mostra inadequada a alcançar o objetivo proposto é que deverá ser infirmada".

Já no tocante ao juízo de necessidade, deverá sempre se indagar se não existe meio menos gravoso ao alcance do Estado para que se chegue ao fim proposto.

À análise de tais critérios, consoante afirma Ângelo Roberto Ilha da Silva, caso aferidos, se seguirá uma verificação da proporcionalidade em sentido estrito, "o qual solicita a aferição do resultado pretendido à luz de um prognóstico de justa medida entre este (o resultado) e o meio coativo", partindo-se sempre de "uma razoabilidade na relação entre o meio e o fim". 247

Neumann aponta tratar-se de um princípio "fraco", dependente demasiado de uma série de valorações, que não são passíveis de decisões consensuais indiscutíveis, mas acrescenta que tal deficiência não diminui "sua potência argumentativa para a efetiva limitação do direito penal". ${ }^{248}$

\footnotetext{
${ }^{245}$ Princípio da proporcionalidade. In. Revista Brasileira de Ciências Criminais. n. 71. São Paulo: Revista dos Tribunais, março-abril de 2008, p. 207. Vide também: ANDRADE, Manuel da Costa. A dignidade penal e a carência de tutela penal. In: Revista portuguesa de ciência criminal. Ano 2, t. 2, Coimbra: Aequitas, abr./jun. 1.992 , p. $173-205$

${ }^{246}$ Op. cit., p. $103-104$

247 “"...] havendo dois meios igualmente adequados para alcançar-se a consecução de um fim que o direito demanda, figurará como proporcional - pressupondo-se presente a necessidade - aquele que se apresentar como menos gravoso. (Op. cit., p. 105). Acerca do tema: "A racionalidade ou proporcionalidade stricto sensu implica justa medida; que a providência não fica aquém ou além do que importa para se obter o resultado devido, nem mais, nem menos; e porque se trata de limites, de restrições e de suspensão de direitos fundamentais, ela traduz-se em proibição do excesso ou do arbítrio; os direitos podem ser limitados, restringidos ou suspensos apenas na medida da necessidade legitimamente acolhida pelos órgãos competentes, à face das normas constitucionais aplicáveis". (MIRANDA, Jorge. Manual de direito constitucional. $2^{\text {a }}$ ed. Coimbra: Coimbra Ed., 1998. t. IV, p. 218-219)

248 "Quando neste ponto perguntamos em que medida se pode avaliar a capacidade do princípio da proporcionalidade como limitador do direito penal, o balanço resulta inicialmente bastante moderado. Tratase, conforme diagnosticamos, de um princípio fraco, no que diz respeito a seus pressupostos, porque reclama uma pluralidade de valorações que não podem ser por ele mesmo determinadas. Neste sentido, justifica-se o difundido ceticismo em face de sua capacidade como limitador da atividade legislativa. Ele não põe à disposição qualquer mecanismo apto a conter leis penais, de acordo com o direito constitucional ou
} 
Diante do exposto no presente apartado, ainda que não se possa proclamar uma verdade absoluta acerca do conceito de bem jurídico, fato é que deste não se pode prescindir como referente material do tipo penal, sendo certo, ademais, que qualquer tentativa de criminalização de condutas, especialmente no âmbito do chamado direito penal econômico, deve ser precedida de uma valoração à luz dos princípios limitadores da intervenção penal, a fim de se evitar uma inadequada utilização simbólica do direito penal.

\subsubsection{O bem jurídico nos crimes contra o mercado de capitais}

No tocante à delimitação do bem jurídico tutelado nos crimes contra o Mercado de Capitais, chama atenção a escassez de textos doutrinários no Brasil; motivo pelo qual nos socorremos no presente trabalho da doutrina estrangeira, que desde há muito vêm enfrentando a questão, sem, contudo, que se possa destacar a existência de uma corrente única de pensamento.

\subsubsection{Tutela patrimonial dos investidores}

Destacamos, em primeiro lugar, a corrente que estabelece o bem jurídico penalmente tutelado nos crimes contra o Mercado de Capitais como proteção aos interesses patrimoniais dos investidores.

Tal posicionamento é majoritariamente vigente no sistema norte-americano, berço das iniciativas de tutela do Mercado de Capitais e com forte influência nos modelos de regulação aplicados nos demais sistemas legais, como o europeu e o brasileiro.

princípios gerais de direito, na medida adequada. O que tampouco, sendo realistas, se pode dele exigir. Princípios jurídicos não são guilhotinas, mas argumentos, que podem ser colocados em campo a favor ou contra determinadas regulamentações. Sob este aspecto, a eficiência do princípio merece outro julgamento. Ele fornece um modelo argumentativo com o qual a crítica jurídico-política a uma regulamentação penal pode ser transformada em relevante veredicto jurídico-positivo. Nesta função, é um forte aliado de um direito penal liberal, porque dificilmente permite a ponderação com contra-argumentos. $O$ argumento da desproporcionalidade de uma intervenção é, normalmente, um argumento vencedor - é má estratégia de reconhecer a desproporcionalidade de uma desejada intervenção e apostar na preponderância de contraargumentos". (Op. cit., p. 227-228) 
São encontrados no sistema norte-americano dois enfoques distintos para a proteção do Mercado de Capitais, a saber, a Teoria do Dever Fiduciário (Fiduciary Duty Teory) e a Teoria da Apropriação Indevida (Misappropriation Teory).

Inicialmente, a regulação penal do Mercado de Capitais nos Estados Unidos teve como base a violação de regras de formação do próprio negócio, decorrente da Teoria das Circunstâncias Especiais (Special Facts Teory), baseada na obrigatoriedade de plena informação à contraparte quando a negociação estivesse baseada em uma informação privilegiada. ${ }^{249}$ Trata-se, contudo, de regra muito mais afeita à boa fé contratual, sem maiores repercussões na esfera penal, demonstrando, portanto, alcance muito restrito, ${ }^{250}$ sendo superada a partir de 1.934, com a edição da Securities Exchange Act, que por meio de sua seção 16(b), passou a definir a responsabilidade do insider para com a companhia emissora, delimitando seu âmbito de alcance aos acionistas detentores de mais de $10 \%$ do capital social, administradores e altos empregados das companhias emissoras dos valores mobiliários. Ainda assim, a punição estava restrita à devolução em favor da sociedade o lucro auferido em razão das operações.

Tal regra, de início, passou a apresentar certas vulnerabilidades, posto que sua vinculação recaiu necessariamente sobre as partes negociantes - integrantes de uma relação normal de confiança - e em especial pessoas ligadas à sociedade emissora dos valores mobiliários negociados, via de regra, os detentores das informações relevantes. Desde logo, os tribunais norte americanos passaram a lidar com situações em que os divulgadores da informação privilegiada nem sempre eram pessoas ligadas à sociedade emissora ou mesmo contra-parte na negociação de valores, como, por exemplo, funcionário de uma gráfica onde se imprimiu o material confidencial. ${ }^{251}$

Esta situação começa a ser alterada por meio de relevante mudança de postura da SEC - Securities and Exchange Commission -, que passou a entender a prática do insider trading como fraude na negociação de valores mobiliários, editando a regra 10B-5, de forma a regulamentar a Securities and Exchange Act de 1.934. O dispositivo em

\footnotetext{
${ }^{249}$ Nesse sentido, o julgamento da Suprema Corte dos Estados Unidos da América em 1.909, no caso Strong vs. Repide. (http://supreme.justia.com/us/213/419/case.html - consultado em 06.12.08)

250 HERNÁNDEZ SAINZ, Esther. El abuso de información privilegiada en los mercados de valores. Pamplona: Thomson, 2007, p. 215. PINTO, Frederico de Lacerda da Costa. O novo regime de crimes $e$ contra-ordenações no código dos valores mobiliários. Coimbra: Almedina, 2000, p. 45-46
} 
comento vem a consagrar a regra do disclose or abstain, vale dizer, ao detentor da informação privilegiada é dada apenas uma das seguintes alternativas, revelar a informação ou abster-se de negociar.

A primeira interpretação que se deu quanto ao objeto de tutela da regra 10B-5, foi no sentido de se proteger o patrimônio dos investidores, ante a quebra de um dever fiduciário dos administradores e altos funcionários das sociedades emissoras para com os investidores. Tal dever, segundo a norma em questão, passou a ser também extensivo a todos aqueles que, por alguma razão, tomaram conhecimento da informação com base em uma relação de confiança que os conecta com os investidores, como, por exemplo, auditores, advogados e consultores.

Ao longo do tempo, ganhou espaço na interpretação das cortes daquele país posicionamento favorável à Teoria da Apropriação Indevida (Misappropriation Teory), como uma tentativa da própria SEC em ampliar o espectro de alcance da vedação ao insider trading para além daqueles detentores de um dever de fidúcia para com os investidores.

Segundo tal teoria, aquele que utiliza de forma indevida a informação privilegiada se apropria indevidamente da informação em relação ao seu proprietário originário. ${ }^{252}$ Alarga-se aqui o conceito de dever fiduciário, que se estabelece não apenas para com os investidores; mas também para com a fonte da informação privilegiada. ${ }^{253}$ Este entendimento enfrentou diversas críticas, especialmente no tocante a uma exagerada ampliação do dever de confidencialidade, importando em um conceito de fraude para além do pretendido pela regra 10B-5. Ademais, segundo as críticas apontadas, ficariam impunes aqueles que obtiveram acesso à informação privilegiada por mera obra do acaso, ou mesmo aqueles sob os quais não recai qualquer dever de confidencialidade, como aquele que dolosamente intercepta a informação. ${ }^{254}$ A teoria da apropriação indevida foi, ao longo do tempo, superada pela a jurisprudência norte-americana, voltando a prevalecer naquele país a teoria do dever fiduciário, exclusivamente fundada na proteção dos investidores.

\footnotetext{
${ }^{251}$ PINTO, Frederico de Lacerda da Costa. Op. cit., p. 47

${ }^{252}$ Idem

${ }^{253}$ HERNÁNDEZ SAINZ, Esther. Op. cit., p. 224-225
} 
A concepção do dano patrimonial dos investidores como bem juridicamente protegido nos crimes contra o Mercado de Capitais encontrou guarida em diversos autores na Europa continental. ${ }^{255}$

No tocante à proposição dos interesses patrimoniais dos investidores como bem juridicamente protegido nos crimes contra o Mercado de Capitais, a doutrina aponta algumas críticas dignas de análise.

Em primeiro lugar, se sustenta que, na prática, existe grande dificuldade em se averiguar os efetivos danos causados aos investidores em decorrência de ações criminosas lesivas ao Mercado de Capitais.

O Mercado de Capitais tem suas negociações caracterizadas, via de regra, pela impessoalidade e anonimato entre as partes. Trata-se de verdadeiro jogo de "soma zero", onde uma das contra-partes sempre perde, dado que as cotações dos valores imobiliários são variáveis de acordo com a relação oferta e demanda. Decorre daí imensa dificuldade em se identificar os reais prejudicados. Não obstante, deve-se considerar a cada vez maior eficiência dos sistemas e meios de controle das bolsas de valores e órgãos reguladores, como é o caso da CVM brasileira.

Verifica-se, de igual sorte, grande dificuldade em se mensurar os efetivos prejuízos, haja vista, por exemplo, que as cotações nem sempre são influenciadas quando da divulgação de uma informação relevante, tratando-se de verdadeiro exercício de suposições. Existe, ademais, grande diferença entre pequenos e grandes investidores, não apenas quanto à capacidade econômica, mas também quanto ao acesso à informação e à motivação para a realização de negociações com valores mobiliários. ${ }^{256}$ São, pois, diversos

\footnotetext{
${ }^{254}$ Idem, p. 226-227

255 Esther Hernández Sainz aponta como sendo essa basicamente a tomada de postura da doutrina alemã durante as décadas de 1970 e 1980, anos setenta e oitenta. (Op. cit., p. 213)

${ }^{256}$ Conforme aponta Esther Hernández Sainz: “[...] la fundamentación de la figura en la lesión de los intereses de los inversores se enfrenta a un escollo insalvable que es la inexistencia de un daño patrimonial, directo y cuantificable causado por los iniciados a quienes participan en los mercados de valores. Para que los daños patrimoniales a los inversores constituyan el fundamento de la prohibición es imprescindible demonstrar que la conducta de los iniciados causa daños efectivos a los inversores. Como veremos tales daños causados por el iniciado no existen con carácter general. [...] En un mercado impersonal y anónimo como los mercados de valores actuales, esta argumentación es insostenible por varias razones evidentes. La fundamental es que no existeuna relación causal entre las posibles pérdidas o el lucro cesante que experimentan los inversores y la negociación llevada a cabo por el iniciado, pues la operación de éste no es la
} 
os fatores que determinam a formação do preço dos valores mobiliários, havendo substancial dificuldade em se aferir concretamente quais os reais prejudicados e em qual monta.

Tome-se como exemplo uma operação de compra de ações por pessoa que, dispondo de informação relevante ainda não divulgada ao mercado, adquire ações em bolsa de valores. Dias após a divulgação da informação relevante, o preço dos papéis sofre forte movimento de alta. De início, soa óbvio que o vendedor ou vendedores das ações para o insider teriam sofrido prejuízo, posto que se soubessem da existência de tal informação relevante, não teriam vendido os papéis. Tal afirmação é, contudo, relativamente verdadeira. Consoante já esposado, muitos são os fatores que determinam a decisão de vender ou comprar valores mobiliários. Não se pode ignorar que existe grande discrepância - não apenas econômica - entre os níveis de investidores. Desse modo, para a determinação dos reais prejudicados, seria necessário se averiguar não apenas a identidade de todos aqueles que negociaram com o insider, como também quais as motivações que os levaram a se desfazer dos papéis. Isso porque a venda pode ter sido determinada por uma série de influências decorrentes do acompanhamento das estatísticas ou notícias do mercado, como também por uma simples vontade desacompanhada de qualquer influência externa.

Não se pode olvidar, por outro lado, que nem todos os investidores têm acesso à totalidade das informações relativas ao mercado. Assim, considerando a hipótese do parágrafo anterior, mesmo que divulgada a informação relevante, uma pessoa que não a conhecia poderia ter vendido as ações antes que os papéis sofressem considerável alta.

Alguns autores apontam também que o alcance de proteção penal do Mercado de Capitais é mais amplo, não podendo se limitar apenas à proteção patrimonial do investidor. $^{257}$

causa de la decisión del inversor de comprar o vender valores, ni tampoco del precio al que negociaron. [...] sólo en raras ocasiones las negociaciones de los iniciados provocan movimientos en la cotización. [...] Tampoco quienes negociaron en el mismo sentido que el iniciado sufren prejuicio alguno por las negociaciones de éste, puesto que no les une ningún vínculo contractual, ni las transaciones de quine posee información privilegiada influyen en forma alguna en las decisiones adoptadas por quien no la posee." (Op. cit., p. 228-233).

257 "El fundamiento de la prohibición reside en la protección de un bien de caráter colectivo cual es la integridad de los mercados de valores, cuya defensa actúa como barrera ante la produción de otros daños más tangenciales como pudiera ser un hipotético daño patrimonial concreto a uno o varios inversores." 
Objeção feita à definição do interesse patrimonial dos investidores como bem juridicamente tutelado, reside, como faz Patrícia Faraldo Cabana, no argumento de que a adoção de tipos de perigo abstrato afastaria tal possibilidade, ${ }^{258}$ com o que não se pode concordar, tendo em vista a formulação adotada pela teoria pessoal do bem jurídico, que, consoante visto em apartado anterior, comporta uma criminalização pela via dos crimes de perigo abstrato.

Cumpre, dessa forma, ressalvar que diante da formulação de bem jurídico defendida, a lesão patrimonial dos investidores, ainda que mediata, resulta em importante papel para determinação do objeto de tutela, não podendo, portanto, ser afastada completamente. $^{259}$

\subsubsection{Tutela da igualdade entre os investidores}

Outro posicionamento sustentado por parte da doutrina, centrando-se foco ainda em uma pretensa proteção aos investidores, reside na identificação do bem jurídico como a garantia de igualdade entre investidores.

Tal posicionamento não parece de todo equivocado, sendo relevante, todavia, uma correta delimitação do alcance do termo igualdade entre os investidores ${ }^{260}$.

(HERNÁNDEZ SAINZ, Esther. Op. cit., p. 234) "Para resumirlo de uma forma adecuada, se podría decir que queda claro que el patrimônio es parte del bien jurídico protegido, pues se sancoinan sus quebrantos, pero que ello no implica que no haya otros bienes jurídicos protegidos, por lo que se podrían eventualmente sancionar conductas que no conllevan un beneficio económico por más que esto no se haya hecho - o se haya hecho en contadíssimas ocasiones en otros países - hasta la fecha." (MONROY ANTÓN, Antonio J. El delito de abuso de información privilegiada en el mercado de valores. Madrid Dijusa, 2006, p. 141). "[...] é difícil identificar o bem jurídico tutelado pelo crime de abuso de informação com meros interesses individuais. Entender que a incriminação visa tutelar o patrimônio da contra-parte que negoceia com o insider constitui uma limitação considerável ao sentido axiológico da incriminação, pois ignora os efeitos lesivos dessa prática no próprio funcionamento do mercado de valores mobiliários". (PINTO, Frederico de Lacerda da Costa, op. cit., p. 66)

${ }^{258}$ FARALDO CABANA, Patrícia. Algunos aspectos de uso de información privilegiada en el mercado de valores y el proyecto de código penal de 1994. In: Estudios penales y criminologicos. XVIII. Santiago de Compostela: Servicio de Publicaciones e intercambios de la Universidade de Santiago de Compostela, 1995 , p. 62

${ }_{259}$ Vale apontar o posicionamento de Miguel Bajo Fernandéz, para quem esse tipo de delito deve importar dano ao patrimônio, ainda que globalmente considerado, ou em forma de elementos individualizados, como a propriedade, a posse, direitos reais ou direitos de crédito. Compendio de derecho penal, parte especial. Vol II. Madrid: Centro de Estudios Ramon Areces, 1998, p. 341

${ }^{260}$ Nesse sentido, vale transcrever a lição de Esther Hernández Sainz: "El princpio de igualdad de los inversores admite dos interpretaciones. En una concepción muy amplia, la prohibición del uso de 
Consoante se depreende das características próprias do Mercado de Capitais, estudadas anteriormente, é absolutamente impossível se admitir uma estrita igualdade entre os investidores participantes do mercado.

O livre acesso à participação no mercado, uma de suas características mais relevantes, per si, elimina a possibilidade de igualdade entre todos os investidores. Efetivamente inexiste termo de comparação entre grandes conglomerados investidores e os aplicadores individuais, pessoas físicas que fazem de seus investimentos em bolsa uma forma de poupança.

Não apenas a formatação da personalidade jurídica dos investidores define a natureza desigual entre os participantes do Mercado de Capitais, mas também a sua capacidade econômico-financeira, sua formação qualificada, o entendimento acerca do funcionamento do mercado e o acesso às bases estatísticas.

Tal igualdade irrestrita, não pode sequer ser pretendida como uma isonomia de informação. Nesse sentido, um investidor que desempenhe relevante papel em um importante setor da economia, como, por exemplo, a siderurgia, certamente terá uma compreensão muito maior acerca de determinado cenário do que um mero investidor particular. $^{261}$

información privilegiada sería un mecanismo dirigido a garantizar que todos los inversores tuviesen el mismo grado de información al operar en los mercados de valores. Entendido así, es un principio irrealizable en la prática, dadas las diferencias de medios y conocimientos que existen entre las distintas clases de inversores. [...] En una concepción más estricta - que es la seguida mayoritariamente en Europa -, el objetivo que garantiza la prohibición delos abusos de información privilegiada no es la paridad de conocimientos, sino la igualdad en el acesso a la información. [...] El objetivo no es una igualdad de situacionón, sino una simple igualdad de oportunidades. (Op. cit., p. 257-258)

${ }^{261}$ Como afirma Otávio Yazbek: “[...] essas informações não estão sempre disponíveis a todos os agentes. Nos mercados concretos surgem situações diversas de assimetria informacional, em que tais agentes dispõem de dados distintos, tanto sob aspecto quantitativo, quanto sob o aspecto qualitativo. Além disso, eles podem dispor, também de fontes que lhe permitam o acesso privilegiado a informações. [...] A sua existência pode, na verdade, trazer uma série de possíveis distorções aos mercados, não apenas por sabotar, de pronto, a presunção de plena informação que serve de pano de fundo para a análise do equilíbrio, mas também pela sua capacidade de gerar outros efeitos, mais concretos". (Op. cit., p. 42-43) 
Resta claro, portanto, que pretender uma absoluta igualdade entre investidores no Mercado de Capitais é absolutamente inatingível. ${ }^{262}$ Tal diferença não justifica, contudo, a prática de ilícitos como o uso de informação privilegiada. ${ }^{263}$

Diante do exposto, o que se deve pretender é a tutela de uma igualdade no acesso à informação entre os investidores, garantindo-se, dessa forma, uma justa igualdade de oportunidades na participação no Mercado de Capitais. ${ }^{264}$

Essa é justamente a posição recomendada pela Diretiva 2003/6/CE, que elenca dentre seus princípios, como função precípua dos meios de comunicação, permitirem "uma maior igualdade no acesso às informações financeiras entre os profissionais dos mercados financeiros e os investidores particulares", ${ }^{265}$ e estabelece ainda a "necessidade de proporcionar aos investidores uma ampla gama de inversões

\footnotetext{
${ }^{262}$ Nesse sentido, Luis Ramon Ruiz Rodriguez, citando Stratenwerth: "Tal como apunta STRATENWERTH, tampoco el criterio de la igualdad delimita el ámbito de protección, ya que la desigualdad real de los inversores en el mercado de valores es un elemento casi connatural a la existencia del mismo [...]. (Protección penal del mercado de valores. Valencia: Tirant Monografias, 1997, p. 327). Vale também transcrever o posicionamento de José de Faria Costa e Maria Elisabete Ramos: "O núcleo do bem jurídico que se quer defender prende-se, de modo inescapável, com a ideia de que a proibição penal do insider trading visa garantir que o mercado de valores mobiliários se paute pelas regras de mercado. A punição dos comportamentos delituosos próprios do abuso de informação não se confirma, por isso, na tutela da igualdade dos investidores em termos informativos, no equal floating. Direccionar o crime de abuso de informação no sentido da tutela exclusiva da igualdade entre os investidores ignoraria que a disparidade informativa entre os agentes que procuram o mercado de valores mobiliários constitui uma característica inelimitável deste universo e, além disso, um pressuposto de sua própria eficiência. [...] Perspectivar o crime de abuso de informação a partir da igualdade de informação entre investidores, em vez de promover um mercado eficiente e atractivo, levaria a que se inibisse indiscriminadamente o uso de qualquer assimetria informativa. Mais. Essa compreensão, além de não aderir à realidade dos mercados de valores mobiliários, não teria a ductilidade suficiente para conseguir o adequado enquadramento de concretas situações em que o plus informacional de que o agente beneficia não se encontra abrangido pelas margens de punibilidade próprias do crime de abuso de informação." (FARIA COSTA, José de; RAMOS, Maria Elisabete. $O$ crime de abuso de informação privilegiada - a informação enquanto problema jurídico penal Coimbra: Coimbra Editora, 2006, p. 38-39)

${ }^{263}$ Conforme assevera Frederico de Lacerda da Costa Pinto: "Desequilíbrios desta natureza só são aceites num sistema liberal enquanto expressão de um mérito próprio, no caso concreto na obtenção e análise da informação económica que suporta as decisões racionais de investimento". (Op. cit., p. 68)

${ }^{264}$ Monroy Antón, citando Gómez Iñiesta, afirma que: "La teoria de igualdad de oportunidades consiste em que 'el inversor há de saber que em la realización de sus actividades y operaciones en el mercado todos tienen las mismas posibilidades y que ningún inversor va a obtener ventajas extraordinarias"”. (GÓMEZ IÑIESTA, D.J. La utilización abusiva de información privilegiada en el mercado de valores, p. 269. Apud, MONROY ANTÓN. Op. cit, p. 142). E prossegue: "Por supuesto, esta creencia del inversor debe referirse a un derecho a la información y, por consiguiente, a unaobligación de absternerse de realizar operaciones para aquéllos que cuenten con información privilegiada. En ningún caso, por tanto, debe entenderse como un derecho de igualdad absoluta de trato en otros aspectos como comisiones, acceso a informaciones elaboradas por sociedades de valores para clientes con cierto volumen transacional, rapidez en el accesso a la información una vez hecha pública, etc., pues el mercado de valores es un mercado de competencia y, como tal, ha de tener presentes estas diferencias." (Op. cit., p. 142)
}

${ }^{265}$ Diretiva 2003/6/CE, Considerando 25 
competitivas e um nível de informação e proteção na medida de suas circunstâncias" e "necessidade de situar em pé de igualdade todos os participantes",266.

A jurisprudência norte-americana, em julgamento proferido pelo Tribunal de Apelações do Segundo Circuito, no caso SEC 'versus' Texas Gulf Sulphur Co.,, ${ }^{267}$ firmou entendimento que vai ao encontro do pensamento ora esposado, ao estabelecer como finalidade da proibição ao uso de informação privilegiada, a garantia de que todos os investidores nos mercados despersonalizados tenham acesso em condições de igualdade à informação relevante.

Monroy Antón, citando Arroyo Zapatero, afirma que a proteção do investidor, no sentido de garantir a igualdade de oportunidades em risco mediante a defesa da transparência do mercado, vale dizer, garantindo uma base informativa completa e veraz, constitui um pressuposto imprescindível para o correto funcionamento do mercado. $^{268}$

Nesse sentido tem importante papel a regra do abstain or disclose, já estudada, segundo a qual o detentor de uma informação privilegiada, para realizar qualquer negociação com valores mobiliários, deverá, obrigatoriamente, revelá-la, ou então absterse de negociar.

Esther Hernández Sainz, ao tratar do crime de uso de informação privilegiada, aponta em sentido contrário, ao afirmar que a ratio do bem jurídico ${ }^{269}$ não é evitar uma lesão de igualdade - objetivo moralizador do mercado, mas não a essência de sua tutela - consistindo o desvalor na utilização da informação relevante em benefício próprio, e não na forma de acesso à informação. E vai além, ao propor como bem

\footnotetext{
${ }^{266}$ Diretiva 2003/6/CE, Considerando 43

${ }^{267}$ SEC v. Texas Gulf Sulphur Co., 401 F.2d 833 (2d. Cir. 1968)

${ }^{268}$ Tradução nossa: “[...] la protección del inversor, en el sentido de garantizar la igualdad de oportunidades en el riesgo mediante la defensa de la transparencia del mercado, es decir, garantizando una base informativa completa y veraz, constituye un presupuesto imprescindible para el correcto funcionamiento del mercado" (ARROYO ZAPATERO, L. El abuso de información privilegiada en el Derecho español. Hacia un Derecho penal económico europeo, Madrid: 1992. Apud. Monroy Antón. Op. cit., p. 143)

${ }^{269}$ Cabe aqui uma ressalva quanto ao termo "ratio do bem jurídico". Consoante exposto anteriormente, o bem jurídico cumpre função de conferir um limite material à incriminação de determinada conduta, serve, pois, como limitador da intervenção penal, e não como justificador desta. Acerca do tema, vide MOCCIA, Sergio. Dalla tutela di beni allá tutela di funzioni: tra illusioni postmoderne e riflussi illiberali. Rivista Italiana di diritto e procedura penale. Fasc. 2, 1995
} 
juridicamente protegido no tipo penal de uso de informação privilegiada, a concorrência leal nos mercados de valores mobiliários como forma de vedar o abuso injustificado das ineficiências intrínsecas do mercado. ${ }^{270}$

Segundo a proposta desenvolvida pela autora, é impossível que o Mercado de Capitais seja plenamente transparente, até mesmo em razão da desigualdade inerente aos investidores. Dessa forma, o uso de informação privilegiada, por constituir uma exploração das ineficiências intrínsecas ao mercado acaba por representar uma forma de concorrência desleal. ${ }^{271}$

O comportamento dos participantes de qualquer mercado deve ser pautado pela boa-fé objetiva, e o desvalor da conduta não está na existência de uma vantagem cognoscível, que, per si, não é injusta, mas sim no abuso da situação de ineficiência temporal do mercado. ${ }^{272}$

Nessa mesma esteira de entendimento, como já verificado, José de Faria Costa e Maria Elisabete Ramos apontam para um bem jurídico polifacetado, heterogêneo, representado pela garantia da livre concorrência, que nada mais é, para os autores portugueses, do que uma conjugação entre a confiança e a igualdade dos investidores. ${ }^{273}$

\footnotetext{
270 "Em nuestra opinión, la prohibición del uso de informaciones privilegiadas no tiene fundamiento en la lesión de igualdad de oportunidades de los inversores. Esta tesis representa una utopía con una cierta carga demagógica y en consecuencia engañosa. El principio de igualdad de oportunidades es más bien una tendencia del todo ideal, un objetivo moralizador del mercado de valores, pero no constituye la ratio de la normativa anti-insider. [...] La nota de desvalor en esta figura no proviene de cómo se haya accedido a la información, sino el hecho de utilizar en beneficio propio esa ventaja informativa, aprovechando una situacioón de ausencia de plena transparencia." (Hernadéz Sainz. Op. cit., p. 259-261)

${ }^{271}$ Op. cit., p. 280-281. No mesmo sentido: PRIETO DEL PINO, Ana Maria. Op. cit., p. 198-201

272 Idem, p. 283

273 “[...] a infração existe não para proteger o direito daquela concreta pessoa a comprar os bens a um preço justo e não especulativo, mas antes para proteger o bem jurídico supra-individual expresso no valor que a livre concorrência de mercado apresenta. As pessoas atingidas por uma transação bolsista baseada em informação privilegiada não são só, nem de perto nem de longe, os acionistas da empresa sobre a qual gira a questão, mas antes todo o universo de investidores, efectivo e potencial, que procura o mercado de valores mobiliários. [...] A incriminação do abuso de informação pretende, por um lado, tutelar a confiança dos investidores no correcto funcionamento do mercado e, por outro, proteger a decisão econômica individual no sentido de que esta seja tomada em situação de igualdade de informação para todos os potenciais intervenientes no mercado. Criando-se, assim, as condições de livre concorrência entre os investidores. A norma incriminadora do abuso de informação visa tutelar um bem jurídico mais do que poliédrico, heterogêneo. Heterogeneidade que ressalta da sua diferenciada composição: confiança e igualdade dos investidores." (Op. cit., p. 37-38)
} 
Frederico de Lacerda da Costa Pinto, por sua vez, apresenta proposta semelhante quanto à justificação da criminalização do insider trading, ao conceituar o bem jurídico como sendo a "proteção da função pública da informação enquanto justo critério de distribuição do risco do negócio" no mercado de valores mobiliários. Segundo o autor, quem se utiliza indevidamente de uma informação privilegiada "não agride apenas a igualdade entre os investidores, antes subverte as condições de regular funcionamento do mercado e coloca em perigo os seus níveis de eficiência". ${ }^{274}$

\subsubsection{Tutela da confiança dos investidores}

Ao se avançar na análise do bem juridicamente tutelado, ainda sob um enfoque direcionado à tutela dos interesses dos investidores, verifica-se uma corrente que toma o bem jurídico como sendo a confiança destes no regular funcionamento do mercado.

Marco fundamental para o desenvolvimento de tal posição na Europa, a Diretiva comunitária $89 / 592 / \mathrm{CEE},{ }^{275}$ que tratou sobre a coordenação das normativas relativas às operações com informação privilegiada, em sua exposição prévia de motivos, assim dispôs: "Considerando que o bom funcionamento do mercado em questão depende em grande medida da confiança que inspire aos investidores". 276

Tal posicionamento foi em parte corroborado pela Diretiva 2003/6/CE, ao apontar a confiança como um dos valores a serem tutelados:

O bom funcionamento dos mercados dos valores mobiliários e a confiança do público nos mesmos mercados são uma condição essencial do crescimento econômico e da prosperidade. As situações abuso de mercado prejudicam a integridade dos mercados financeiros e a

\footnotetext{
274 “As normas do abuso de informação punem uma situação de distorção da livre concorrência por assimetria quanto à posse e uso de informações relevantes. A justa distribuição do risco negocial próprio do investimento no mercado de valores mobiliários pressupõe uma situação de paridade informativa básica e padronizada (pelas regras legais da full disclosure) face ao bem econômico que permite tomar decisões tomar decisões racionais de investimento (a informação)". (Op. cit., p. 67)

${ }^{275}$ Tal orientação chegou a ter grande influência, especialmente no tocante à doutrina espanhola: ARROYO ZAPATERO, Luis. El abuso de información privilegiada en el Derecho español. Hacia un Derecho penal económico europeo, Madrid: 1992. Apud. Monroy Antón. Op. cit., p. 159. FARALDO CABANA, Patricia. Op. cit., p. 61. GÓMES IÑIESTA, Diego J. La utilización abusiva de información privilegiada en el mercado de valores. Barcelona: Mc Graw Hill, 1997, p. 292. CALDERÓN SUSÍN, Eduardo. El abuso de información privilegiada en el mercado de valores. In: Cuadernos de Derecho Judicial, 1996, p. 230

${ }^{276} \mathrm{http}$ ://eur-lex.europa.eu/RECH_menu.do?ihmlang=pt - consulta em 08.01.09
} 
confiança do público nos valores mobiliários e instrumentos derivados. $^{277}$

Pois bem, o alcance dessa confiança plena dos investidores no mercado de valores mobiliários parece um objetivo por deveras utópico, ainda que não possa ser ignorado. A própria desigualdade entre investidores - fator intrínseco ao mercado -, como, por exemplo, no acesso à informação, há de gerar margens a desconfianças.

Por outro lado, alcançar a confiança dos investidores no mercado é algo muito mais relacionado com os efeitos gerados por uma eficiente regulação do que com os fundamentos da tutela penal ou mesmo administrativa. ${ }^{278}$ Sob tal aspecto, aliás, resta claro que tanto uma regulação administrativa adequada, como a garantia de igualdade de oportunidades entre os investidores e, em última análise, o correto funcionamento do mercado são capazes de proporcionar a confiança pretendida. ${ }^{279}$

A experiência demonstra que nos casos em que tenha ocorrido manipulação de mercado ou uso indevido de informação privilegiada, a quebra de confiança recai muito mais sobre as sociedades emissoras dos valores mobiliários do que sobre o mercado como um todo.

A adoção da confiança como bem juridicamente protegido, sem sombra de dúvida, traria margem a uma criminalização fundada exclusivamente em tipos de perigo abstrato, ${ }^{280}$ cuja adoção inspira, conforme já visto, demasiada cautela. Ademais, tutelar a

\footnotetext{
${ }^{277}$ Considerando $\mathrm{n}^{\circ}$ 2. Em semelhante sentido, o considerando $\mathrm{n}^{\circ} 12$ : "O abuso de mercado abrange o abuso de informação privilegiada e a manipulação de mercado, $\mathrm{O}$ objectivo da legislação contra o abuso de informação privilegiada é o mesmo da legislação contra a manipulação de mercado: garantir a integridade dos mercados financeiros comunitários e promover a confiança dos investidores nos mesmos. Por conseguinte, é aconselhável adoptar regras conjuntas para combater tanto o abuso de informação privilegiada como a manipulação de mercado. Uma directiva única garantirá o mesmo enquadramento em toda a Comunidade para a atribuição de responsabilidades, aplicação da legislação e cooperação".

${ }^{278}$ Na mesma esteira de entendimento: PRIETO DEL PINO, Ana María. (Op. cit., p. 196-197) e MONROY ANTÓN, Antonio J. (Op. cit., p. 153)

${ }^{279}$ Nesse sentido, Esther Hernández Sainz: "El refuerzo de la confianza de los inversores no puede ser presentado como el fundamento de la represión del disfrute en bolsa de informaciones privilegiadas, dado que eso supone confundir la causa de la incriminación con sus teóricos efectos. La pérdida de confianza se produce porque se percibe que esas conductas causan un daño, luego es la eliminación o minimación de ese daño lo que constituye el fundamento jurídico de la prohibición y no la pérdida o el incremento de la confianza de los inversores, que será el efecto de una política permisiva o prohibitiva de las condutas que causan tales daños." (Op. cit., p. 265) Em idêntico sentido MONROY ANTÓN, Antonio J. (Op. cit., p. 162)

${ }^{280}$ Consoante apregoa MONROY ANTÓN: "Si el bien jurídico fuese la confianza de los inversores, se sancionaría tanto la conducta que obtiene finalmente benefícios como la que no lo hace, ya que parece claro
} 
confiança enquanto bem jurídico afasta, sobremaneira, o objeto da proteção penal do referencial antropocêntrico vinculado à dignidade humana, acarretando uma indesejável subjetivação do Direito Penal.

\subsubsection{Tutela dos interesses da sociedade emissora dos valores mobiliários}

Por outro lado, alguns posicionamentos doutrinários defendem como bem juridicamente protegido os interesses das sociedades emissoras de valores mobiliários, especialmente na Suíça, país no qual prevalece o entendimento de que a criminalização do insider trading objetiva proteger, em primeiro lugar, a igualdade de oportunidades dos investidores no mercado, e, em segundo plano, os interesses da empresa emissora, em decorrência de um dever de lealdade que vincula o insider - assim considerado aquele que de forma direta ou indireta mantém uma relação de fidúcia com a sociedade emissora empresa. $^{281}$

Tanto assim, que perante a legislação suíça os insiders que tenham dever de lealdade para com a empresa emissora estão sujeitos a uma pena maior do que aqueles livres de tal vinculação. Note-se, ainda, que essa segunda categoria somente estará sujeita a uma responsabilização de cunho penal quando a prática do crime se der em concurso necessário - com insiders vinculados à sociedade por meio de um dever de fidúcia. ${ }^{282}$

Essa teoria foi desenvolvida a partir do sistema de proteção norteamericano, todo fundamentado na garantia de um dever de lealdade, de início vinculando apenas os acionistas, administradores e altos funcionários (fiduciary theory), e cujo alcance foi posteriormente alargado (misappropriation theory). Importante ressalva cabe aqui, posto que, não obstante tratar-se de teoria desenvolvida a partir do sistema criado nos

que la confianza del inversor en el sistema se resentiría, en todo caso, por el mero hecho de saber que alguien tiene acceso a la información antes que él y puede operar con ciertas venajas [...]”. (Op. cit., p. 162)

281 PRIETO DEL PINO, Ana María. El DerechoPpenal ante el uso de información privilegiada en el mercado de valores. Navarra: Editorial Arazandi, 2004, P. 185. Sobre o tema: "En la actualidad esta perspectiva societaria de los abusos de informacion privilegiada está superada, puesto que la figura se regula en la normativa del mercado de valores y tiene un ámbito subjetivo muy amplio, que supera con creces el marco societario. El art. $81 \mathrm{LMV}$ considera iniciados a cualesquiera sujetos y no sólo a los administradores o altos cargos societarios. Se hace evidente que los interesses protegidos por el art. 81 LMV necessariamente van más allá del ámbito societario, para situarse en la defensa de intereses colectivos como la integridad del mercado." (HERNÁNDEZ SAINZ, Esther. Op. cit., p. 236)

${ }^{282}$ Idem 
Estados Unidos, o enfoque suíço recai sobre um dever de lealdade do sujeito para com a empresa, enquanto que o norte-americano se dá para com a tutela dos investidores. ${ }^{283}$

Contudo, essa não também parece a saída mais adequada, na medida em que os interesses a serem protegidos no mercado de capitais vão, evidentemente, muito além dos interesses das companhias que lançam seus papéis no mercado como forma de captação de recursos.

Admitir como bem juridicamente tutelado apenas os interesses das companhias emissoras seria, no mínimo, ignorar a relevância do papel desempenhado pelos investidores que, com seus recursos, financiam as companhias emissoras por meio da aquisição dos valores mobiliários.

Tomando-se como exemplo a questão das informações relevantes, quer com o seu uso de forma privilegiada, quer a divulgação de forma manipulada, com o intuito de alterar artificialmente a cotação dos papéis negociáveis em mercado, parece claro que não se trata de um bem da própria sociedade; mas sim de um bem público.

Ademais, a experiência mostra que os delitos perpetrados contra o mercado de capitais muito pouco, ou quase nada, afetam o valor das cotações dos papéis negociados em mercado. ${ }^{284}$ Quando muito, resta abalada a credibilidade das companhias emissoras, havendo, sem dúvida alguma, meios outros, que não a intervenção penal, para a tutela e reparação dos interesses das sociedades emissoras.

\footnotetext{
${ }^{283}$ Idem, p. 184

284 "También la jurisprudência nortamericana demuestra em algunos de sus casos la insuficiência, por no decir la invalidez absoluta, de esta teoria. Em el caso U.S. contra Carpenter se presentaba a um reportero del Wall Street Journal, Foster Winans, que gozaba de gran prestigio entre los inversores y que, com sus artículos, titulados como 'Oído em la calle', llegaba a afectar al precio de los valores sobre los que escribía. Este reportero contactó con dos empleados de una casa de Bolsa, haciéndoles saber el contenido de sus artículos antes da la publicación, con lo que estos generaron amplios beneficios en cortos períodos de tiempo. A pesar de que la sentencia condenatoria se basó en que la información transmitida no era de propiedad del reportero, sino del periódico, concluyendo que había un deber de lealtad que aquél había incunplido, los procesados, con total razón, alegaron el absurdo que suponía castigar a un empleado por actos que supuestamente y según la sentencia - su empresa podía cometer con total impunidad. Ello demuenstra que los intereses dela empresa no deben ser el bien jurídico protegido en el delito de iniciados. Para resumir este apartado, hay que señalar que el mercado tiende a interpretar que el aprovechamiento en beneficio propio de la información privilegiada lo hace una persona concreta, y que para nada tiene que ver la conducta de dicha persona con la marcha de la sociedad. [...] La difución en prensa de casos de posibles delitos de información privilegiada no ha afectado en absoluto la cotización de las empresas, ni siquiera en el corto prazo. [...] Por tanto, esta teoría debe ser desechada como integrante del bien jurídico protegido en el delito estudiado." (Monroy Antón. Op. cit., p. 148-150)
} 
A adoção da teoria ora esposada, por outro lado, traz à baila outro ponto de importante reflexão, pois a tutela penal dos Mercados de Capitais, embasada somente na quebra de um dever de lealdade para com a sociedade emissora restringiria as possibilidades quanto à definição dos sujeitos ativos do crime, deixando de lado aquelas pessoas que não possuem qualquer dever de lealdade, seja direta ou indiretamente, com a empresa. $^{285}$

Ressalve-se, quanto a este aspecto, que os deveres de lealdade dos administradores para com as sociedades são usualmente objeto de proteção penal, tal como ocorre em nossa legislação, com os crimes violação de segredo profissional e de fraude e abusos na administração de sociedade por ações. ${ }^{286}$

Nesse diapasão, consoante afirma Frederico de Lacerda da Costa Pinto, relativamente ao crime de insider trading, os interesses da empresa, enquanto eventual ofendido já são protegidos por via das incriminações que visam tutelar os segredos patrimoniais ou industriais, "sendo uma repetição inútil integrar esse objeto de tutela na incriminação do abuso de informação, e vai além, ao considerar que tais aspectos podem ser dogmaticamente considerados como consequiências mais ou menos remotas das práticas ilícitas, mas não necessariamente efeitos lesivos sobre o bem jurídico". ${ }^{287}$

\subsubsection{Tutela do correto funcionamento do mercado de valores mobiliários}

Resultante da insuficiência de argumentos que justifiquem tão somente os interesses patrimoniais dos investidores como bem juridicamente protegido, procurou-se, por meio da formulação da teoria de proteção do correto funcionamento do Mercado de

\footnotetext{
285 "De admitirse que el fundamiento de la prohibición reside exclusivamente en la protección de los interesses de la sociedad se restringiría notablemente sú ámbito operativo. Sólo podría impedirse la utilizacíon de información privilegiada a quienes tuviesen un deber de lealtad frente a la sociedad y, sin embargo, en la prática personas extrañas a la organización de la misma cometen abusos de información privilegiada. [...] El fundamento de la prohibición contenida en el art. 81 LMV reside en la protección del interés colectivo en la integridad del mercado de valores, aunque esa prohibición también sirva indirectamente para la protección de los intereses de las sociedades cotizadas. Ciertos supuestos de abuso de información privilegiada de carácter interno, son susceptibles de provocar un daño a la sociedad, por lo que es muy positivo que, junto a la imposición de una sanción administrativa, por el daño causado al mercado; pueda interponerse contra ellos la ación social de responsabilidad al objeto de que la sociedad se resarza de los daños que se le causaron.” (Hernández Sainz, op. cit., p. 245-246)

${ }^{286}$ Respectivamente, artigos 154 e 177, do Código Penal brasileiro
} 
Capitais, conjugar a tutela penal dos interesses dos indivíduos, com os dos outros atores do mercado, como as sociedades emissoras. Tal enfoque, como observa Ana María Pietro Del Pino, encontrou guarida majoritária na doutrina espanhola, ${ }^{288}$ fenômeno verificado também junto à doutrina brasileira. ${ }^{289}$

Inequívoco que o correto e adequado funcionamento do Mercado de Capitais constitui, nos dias atuais, peça fundamental dos sistemas econômicos. Tal entendimento resta claro quando da leitura dos considerandos preambulares da Diretiva 2003/6/CE, do Parlamento Europeu: "A criação de um mercado financeiro integrado e eficiente pressupõe que seja garantida a integridade do mercado". ${ }^{290}$

Conforme aponta Monroy Antón, a Teoria do correto funcionamento do mercado de valores mobiliários tem sustentáculo em três pilares: a proteção dos investidores, a igualdade entre estes e a transparência das informações. ${ }^{291}$

\footnotetext{
${ }^{287}$ Op. cit., p. 66

${ }^{288}$ RODRÍGUEZ MOURULLO, G.: " La utilización abusiva de información privilegiada en el mercado de valores ante el Derecho Penal”, en Poder Judicial, núm. IX, 1988, pág. 247; GONZÁLEZ CUSSAC, J. L.: “ El abuso de información privilegiada...”. Op.cit., págs. 140-142, si bien este autor considera que el bien jurídico protegido por el delito de inciados debe combinar el aspecto supraindividual relativo al correcto funcionamiento del mercado de valores con los intereses particulares de los inversores; TERRADILLOS BASOCO, J.: Derecho penal de la empresa, Trotta, Madrid, 1995, pág.191, quien tambíen incide en la tutela de los inversores; RUIZ RODRIGUEZ, L. R.: Protección penal del mercado de valores ( infidelidades en la gestión de patrimonios), Triant lo Blanch, Valencia, 1997, págs. 330 y 331; GONZÁLEZ RUS, J.J.: “ Aproximación a los delitos contra el orden socioeconómico en el Proyecto de Código penal de 1992”, en Hacia un Derecho penal económico europeo, Jornadas en honor del Profesor Klaus Tiedemann, Boletín Oficial del Estado, 1995, pág. 183; HERNÁNDEZ, SAINZ, E.: "La nueva regulación penal de los abusos de información privilegiada". Op. cit, pág. 188; LÓPEZ BARJA DE QUIROGA, J.: "El "insider trading", en ADPCP, 1993, pág. 1034; MARTÍNEZ- BUJ NA PÉREZ, C.: “ Comentário al artículo 285 del Código penal”, en Comentarios al Código penal de 1995 ( Coord.: VIVES ANTÓN), Tirant lo Blanch, Valencia, 1996, págs.1382 y 1383; SÁNCHES-CALERO GUILARTE, J./ TAPIA HERMIDA, A.J.: "El Abuso de informacion privilegiada". Op. cit. Pág.769; QUERALT JIMÉNEZ, J.J.: Derecho penal español. Parte especial. 3. ${ }^{a}$ edic, conforme al Código penal de 1995. Delitos contra los intereses individuales y coletivos, Bosch, Barcelona, 1996; BAJO, M./BACIGALUPO, S.: Derecho Penal Económico, ed.Centro de Estudios Ramón Areces, Madrid, 2001, págs. 523 y 524; MORENO CÁNOVES, A./RUIZ MARCO, F.: Delito socioeconómicos. Comentarios a los arts. 262, 270 a 310 del nuevo Código penal (concordados y con jurisprudencia), ed. Edijus, 1996, págs.205 a 210; vid., asimismo, MARTIN PALLÍN, J. A.: “ Uso de información relevante para la cotización en mercado de valores", en VV AA: Delitos relativos a la propiedad industrial, al mercado de valores y los consumidores ( dir. B. DEL ROSAL BLASCO), CGPJ, Madrid, 1997, pág.157. (Op. cit., nota n. 212, p. 197)

${ }^{289}$ CARVALHOSA, Modesto; EIZIRIK, Nelson. A nova Lei das S/A. São Paulo: Saraiva, 2002, p. 530 e ss. PAULA, Áureo Natal de. Crimes contra o Sistema Financeiro Nacional e o mercado de capitais. Curitiba: Juruá, 2006, p. 11 e ss. DE SANCTIS, Fausto Martins. Punibilidade no Sistema Financeiro Nacional. Campinas: Millenium, 2003, p.99

${ }^{290}$ Considerando ${ }^{\circ} 2$, primeira parte

${ }^{291}$ Op. cit., p. 151 e ss.
} 
No tocante à proteção patrimonial dos investidores, objeto de análise em apartado anterior, não se nega que tenha relevância penal; questionando-se apenas, se é suficientemente segura como interesse legitimamente carecedor de tutela penal.

A igualdade dos investidores, por seu turno, se devidamente conceituada como uma igualdade de oportunidades, consoante estudado, de igual sorte parece, ao menos a priori, estar dotada de relevância para que se pugne por sua tutela sancionatória.

Resta, contudo, saber se a transparência das informações configura pressuposto suficientemente digno de proteção pela via da intervenção penal do Estado, tese que não parece prosperar.

Entende-se por transparência de informações a garantia de divulgação de todas as informações relevantes por parte das empresas que têm valores mobiliários custodiados em Mercado de Capitais. Tal interesse, todavia, se protege por meio da regra do disclosure, - pressuposto de funcionamento do mercado - e não pela via da criminalização.

Nesse sentido, o preciso posicionamento de Esther Hernández Sainz, ao tratar do crime de uso indevido de informação privilegiada:

A proibição do uso indevido de informação privilegiada não garante a transparência, porque não implica, per si, em um incremento dos níveis informativos do mercado, o que se consegue, pelo contrário, com a obrigação de difusão imediata de toda informação relevante. [...] A proibição do uso de informação privilegiada não tem como objetivo direto a salvaguarda da transparência, ainda que, tangencialmente, colabore para sua consecução. Assim, com a proibição se incentiva o uso dos canais oficiais de divulgação da informação [...]. Se esse fosse o fundamento da proibição, deveria restringir-se seu âmbito subjetivo apenas àqueles que têm poder de decisão ou influência no processo de divulgação da informação. A transparência se protege mediante a obrigação de difusão da informação relevante, e não por meio da proibição do insider trading. ${ }^{292}$

\footnotetext{
292 Tradução nossa: "La prohibición del insider trading no garantiza la transparencia, por que no implica per se un incremento de los niveles informativos de mercado que se consigue, por el contrario, con la obligación de difusion inmediata de toda información relevante. [...] La prohibición del uso de información privilegiada no tiene como objetivo directo la salvaguarda de la transparencia, aunque tangencialmente coadyuve a intermediarla. Así, con la prohibición se incentiva el uso de los canales oficiales de divulgación de la información [...]. Sí ése fuse el fundamento de la prohibición debería restringirse su ámbito subjetivo tan sólo a quienes tienen poder de desición o influencia en el proceso de divulgación de la información. La
} 
Em sentido contrário, especificamente com relação ao crime de manipulação de mercado, Frederico de Lacerda da Costa Pinto observa:

[...] as práticas ilícitas previstas no tipo de crime são lesivas dos pressupostos de regular funcionamento de um sector do sistema financeiro, o mercado de valores mobiliários, através do qual se prosseguem finalidades econômicas do Estado, nomeadamente, o encontro entre as poupanças das famílias e a necessidade de financiamento das empresas (cfr. Art. $101^{\circ}$ da Constituição). Mais concretamente, a norma tutela a regularidade e eficiência do mercado de valores mobiliários, através da proteção da qualidade da informação e da transparência do mercado em si mesma. ${ }^{293}$

No tocante ao posicionamento adotado pelo autor português, ainda que demonstre clara preocupação com uma vinculação com os interesses individuais, parece confundir o objeto da tutela penal com os fins a serem alcançados pela regulação do mercado.

Ademais, a experiência mostra que nos casos de ilícitos cometidos contra o Mercado de Capitais, a credibilidade e estabilidade dos mercados não se viu maculada - de fato, mesmo após a divulgação de diversos escândalos, não se observou qualquer diminuição relevante no fluxo de investimentos -, restringindo-se tais efeitos, quando muito, às companhias emissoras dos papéis.

Dessa forma, a transparência das informações constitui um elo fraco para fundamentação do correto funcionamento do mercado de capitais como bem juridicamente protegido, o qual acaba por se apresentar como um conceito deveras amplo - e distante de uma conexão com os interesses e indeterminado - tal como uma proteção aos interesses econômicos gerais - e, conseqüentemente, inapto a justificar a intervenção penal do Estado. $^{294}$

transparencia se protege mediante la obligación de difusión de la información relevante y no mediante la prohibición del insider trading." (Op. cit., p. 250-251)

${ }^{293}$ Op. cit., p. 93-94

${ }^{294}$ Conforme assevera Renato de Mello Jorge Silveira: "Em curta elucidação, poder-se-ia entender que os interesses gerais não se fragmentam, como os difusos, em uma pluralidade de situações subjetivas". (Op. cit., p. 59) Monroy Antón aponta ainda outros problemas quanto à tese: "No cabe Duda de que el legislador há tratado de dar uma especial protección a los intereses generales. Sin embargo, esto nos es suficiente para entender que sea el principal bien jurídico objeto de proteción. [...] Esta teoría encuentra en su origen dos problemas principales: el primero, el de esclarecer qué se entiende por intereses generales, y el segundo y de 


\subsubsection{Conclusões quanto ao bem jurídico protegido}

Vistas as principais teorias expostas pela doutrina estrangeira quanto ao bem juridicamente tutelado, serão apresentadas no presente tópico as conclusões quanto ao bem jurídico protegido, com especial preocupação em se analisar o tema de forma sistemática em relação aos chamados crimes contra o Mercado de Capitais, buscando-se o interesse penalmente relevante a ser tutelado pelas normas incriminadoras, sem distinção quanto aos crimes de manipulação de mercado e uso indevido de informação privilegiada, sendo este último objeto demasiadamente maior de estudo pelos doutrinadores estrangeiros, mas, que acaba, de qualquer maneira, por representar uma forma específica de manipulação.

Em primeiro lugar, há que se fazer uma análise quanto à relevância constitucional do Mercado de Capitais, a fim de que se verifique se este, ou aspectos deste, são efetivamente dignos de tutela, tomando-se o texto da Carta Magna como limite material, fonte valorativa e fundamento normativo do Direito Penal. ${ }^{295}$

Consoante analisado anteriormente, o Mercado de Capitais no Brasil se insere como parte integrante do Sistema Financeiro Nacional, ${ }^{296}$ regulado pela Constituição Federal, por meio do Capítulo IX, do Título VII ("Da Ordem Econômica e Financeira). Nesse contexto, tem especial relevância o artigo $192,{ }^{297}$ pelo qual o legislador

mayor transcendencia, el de decidir cuando se pueden estar poniendo en peligor esos intereses generales con motivo del uso de información privilegiada”. (Op. cit., p. 154-153)

${ }^{295}$ Consoante a lição de Miguel Reale Júnior, o bem jurídico consiste em um dado valorativo que antecede a própria criação do delito: “[...] o bem jurídico preexiste à construção normativa, sendo objeto da escolha do legislador enquanto valor digno de tutela". Outrossim, os bens jurídicos são valores predominantes na sociedade que devem, também, apresentar relevância e respaldo constitucional, discutindo-se se o respaldo constitucional deve ser expresso ou se pode ser implícito. (REALE JÚNIOR, Miguel. Despenalização no direito penal econômico: uma terceira via entre o crime e a infração administrativa? Revista Brasileira de Ciências Criminais, São Paulo, v. 7, fasc. 28, p. 121, out./dez. 1999) E também: FELDENS, Luciano. Direitos fundamentais e direito penal: garantismo, deveres de proteção, princípio da proporcionalidade, jurisprudência constitucional penal, jurisprudência dos tribunais de direitos humanos. Porto Alegre: Livraria do Advogado, 2008, p. 31-51

296 "O Mercado de Capitais é parte integrante do Mercado Financeiro, que como termo genérico também abrange o Mercado Monetário, o Mercado de Divisas e o mercado a termo”. (KÜMPEL, Siegfried. Op. cit, p. 48)

297 "Art. 192 - O sistema financeiro nacional, estruturado de forma a promover o desenvolvimento equilibrado do País e a servir aos interesses da coletividade, em todas as partes que o compõem, abrangendo as cooperativas de crédito, será regulado por leis complementares que disporão, inclusive, sobre a participação do capital estrangeiro nas instituições que o integram." (Redação dada pela Emenda Constitucional n. ${ }^{\circ} 40$, de 2003) 
constitucional determinou, como finalidades a serem alcançadas por um Sistema Financeiro Nacional: "promover o desenvolvimento equilibrado do país" e "servir aos interesses da coletividade". ${ }^{298}$

Mas não é só. Inserida como direito fundamental no rol do artigo $5^{\circ}$, da Carta Magna, o direito à propriedade (inciso XXII) assume importante papel quanto à proteção do investidor. Nesse contexto, vale transcrever os apontamentos feitos por Eros Grau:

[...] enquanto instrumento a garantir a subsistência individual e familiar - a dignidade da pessoa humana, pois - a propriedade consiste em um direito individual, e, iniludivelmente cumpre função individual. [...] A essa propriedade não é imputável função social; apenas os abusos cometidos no seu exercício encontram limitação, adequada, nas disposições que implementam o chamado poder de polícia estatal. [...] A propriedade,a afirmada pelo texto constitucional, reiteradamente, no inciso XXII do art. $5^{\circ}$ e no art. 170, III, não constitui um instituto jurídico, porém um conjunto de institutos jurídicos relacionados a distintos tipos de bens. [...] Assim, cumpre distinguirmos, entre si, a propriedade de valores mobiliários, a propriedade literária e artística, a propriedade industrial, a propriedade do solo, $v . g^{299}$

Não resta dúvida, pois, que o Mercado de Capitais e a proteção do investidor por meio da garantia do direito à propriedade estão devidamente inseridos dentro de um contexto constitucional relevante. Resta, ao passo, delimitar o conceito de bem jurídico sistematizado para os crimes contra o mercado de capitais.

No tocante às diversas teorias analisadas nos apartados anteriores, pode-se verificar, de antemão, que a tutela dos interesses patrimoniais dos investidores, não obstante suscetível de críticas quanto a uma concreta dificuldade de identificação das pessoas lesadas e da extensão valorativa dos danos, assume relevo considerável, na medida em que não se pode ignorar serem os investidores que financiam o Mercado de Capitais por meio da alocação de poupança, devendo, portanto, serem tutelados.

\footnotetext{
${ }^{298}$ Consoante aponta Paulo José da Costa Jr., Maria Elizabeth Queijo e Charles M. Machado, “as instituições financeiras privadas ficam assim também e de modo muito preciso vinculadas ao cumprimento da função social bem caracterizada". (Crimes do colarinho branco. $2^{a}$ ed. São Paulo: Saraiva, 2002, p. 26)

${ }^{299}$ GRAU, Eros Roberto. A ordem econômica na constituição de 1988. $9^{\text {a }}$ ed. São Paulo: Malheiros, 2004, p. 214-215
} 
Não se olvide também que o Mercado de Capitais, por apresentar ineficiências intrínsecas - donde decorre a necessidade de uma regulação (em sentido amplo) eficiente - acaba por tornar-se meio propício à prática de irregularidades e crimes, mormente frente à possibilidade de ganhos rápidos e de grande monta. Nesse contexto, a teoria da igualdade de oportunidades dos investidores, que compreende a garantia da livre concorrência no Mercado de Capitais, acaba por assumir papel de relevância. De qualquer forma, parece claro que tal garantia de igualdade de oportunidades desemboca, ainda que de forma indireta, na tutela dos interesses patrimoniais dos investidores.

Quanto à proteção da confiança dos investidores no Mercado de Capitais, tal valor é claramente mera consequência de uma regulação eficiente, bem como está desprovido de necessária concretude que justifique uma tutela penal por parte do Estado.

Por outro lado, a proteção patrimonial e dos interesses das sociedades emissoras, conforme visto, não pode ser a razão da criminalização das condutas lesivas ao Mercado de Capitais, estando já devidamente tutelada por meios próprios e tipos penais específicos, especialmente no tocante à ação das pessoas que têm, para com tais sociedades, um dever de lealdade legal ou contratualmente estabelecido.

Por fim, a teoria que defende o correto funcionamento do Mercado de Capitais como bem juridicamente protegido, parece, prima facie, aglutinar os posicionamentos supra mencionados. Contudo, ainda que seja este o objeto de uma tutela em sentido amplo, com especial destaque para a regulação administrativa, o conceito de correto ou eficiente funcionamento do mercado é por deveras subjetivo e inadequado à proposta de bem jurídico ora adotada.

Tal teoria, consoante mencionado em apartado anterior, foi adotada pela doutrina brasileira, ainda que com ressalvas, com especial destaque para Modesto Carvalhosa e Nelson Eizirik, que assim o definem em termos amplos ${ }^{300}$ e Áureo Natal de

\footnotetext{
300 “O bem juridicamente protegido pela ameaça penal, no art. 27-C, é, genericamente, o da estabilidade do mercado de capitais, mais especificamente, visa a norma proteger o processo de formação de preços dos valores mobiliários no mercado, evitando a sua alteração artificial. [...] Em termos amplos, o bem juridicamente protegido pela ameaça penal contida no art. 27-D da Lei n. 6.385/76, introduzido pela Lei $\mathrm{n}$. 10.303/2001 é o da estabilidade do Mercado de Capitais." (Op. cit., p. 533-534 e 542)
} 
Paula, que aponta para a necessidade de que as condutas sejam caracterizadas por certa lesividade. $^{301}$

Monroy Antón defende uma formulação de bem jurídico atrelada à noção de correto funcionamento do mercado, assim entendido não como bem jurídico difuso, mas como a somatória de diversos bens individuais, notadamente o patrimônio dos investidores, a igualdade de oportunidades entre estes e a transparência do mercado. ${ }^{302}$

Todavia, definir o bem juridicamente tutelado como o correto funcionamento do Mercado de Capitais, não obstante representar uma tendência confortável, não parece a formulação mais adequada.

Dentro de uma proposta de bem jurídico voltada necessariamente a um referencial individualizado e com vistas à garantia da dignidade humana, a noção de correto funcionamento do mercado é por demais aberta, soando muito mais como justificação para uma intervenção penal, o que vai de encontro com a função limitadora do bem jurídico. Nesses termos, defender o correto funcionamento do mercado como bem juridicamente protegido parece aproximar a tutela penal do Mercado de Capitais de um indesejável direito penal simbólico.

Consoante observado em capitulo anterior, o correto funcionamento do mercado é a base para a formulação de uma tutela em sentido muito mais amplo, voltada para uma regulação administrativa eficiente. ${ }^{303}$

Já a tutela dos investidores assume uma posição secundária como objeto da tutela administrativa do mercado de capitais, conforme aponta Siegfried Kümpel:

[...] conforme o entendimento moderno, o Direito do Mercado de Capitais serve prioritariamente à proteção da capacidade funcional do Mercado de Capitais. Um objetivo adicional do Direito do Mercado de Capitais, fortemente ligado à capacidade funcional, é a proteção do investidor. $^{304}$

\footnotetext{
${ }^{301}$ Op. cit., p. 12, 28 e 38

302 "Así, la postura a tomar en cuanto al bien jurídico protegido, sería que éste consiste en el correcto funcionamento del mercado de valores, plasmado a su vez en la defensa del patrimonio de los inversores, la igualdad de oportunidades de los mismos y la transparencia de dicho mercado.” (Op. cit., p. 168)

${ }^{303}$ KÜMPEL, Siegfried. Op. cit., p.21 e ss.

${ }^{304}$ Idem, p. 36
} 
Dessa forma, assumindo seu papel no tocante a uma intervenção subsidiária, o Direito Penal se afigura como instrumento adequado à proteção dos interesses patrimoniais dos investidores, cuja dignidade penal encontra-se devidamente embasada constitucionalmente, especialmente quanto à garantia de um direito fundamental intimamente vinculado à dignidade humana, qual seja, a propriedade dos investidores. Assim, a definição dos interesses patrimoniais dos investidores como bem juridicamente tutelado nos crimes contra o Mercado de Capitais dá a este, sem sombra de dúvida, a concretude e vinculação a interesses individuais essenciais necessárias, conforme a teoria pessoal do bem jurídico ora adotada.

Nesse sentido aponta Luis Ramon Ruiz Rodriguez, ao identificar a atividade bursátil dos investidores como bem juridicamente protegido no crime de insider trading. Consoante defende o autor, é esta a atividade observada no mercado de valores mobiliários que realmente se dirige a satisfazer necessidades concretas. ${ }^{305}$

Cumpre, todavia, esclarecer que o conceito de investidores ora apontado como bem juridicamente tutelado tem um espectro mais amplo do que aqueles individualmente considerados. Trata-se aqui da tutela dos interesses do público investidor, assim considerados os investidores efetivos e em potencial. ${ }^{306}$

\footnotetext{
305 “ “...] es la actividad inversora, la participación en el mercado de valores, lo que debe marcar la protección legal. Esta participación en el mercado no es más que una manifestación específica del genérico mandato constitucional enviado a los poderes públicos para que faciliten la participación cuidadana en la economía. De esta forma, la igualdad de los inversores y la consecución de un mercado de valores tranparente y creíble serán los presupuestos necesarios para que la actividad inversora de quien pretende aumentar su riqueza pueda alcanzar los objetivos hacia los que dicha actividad está encaminhada. [...] Pero, donde realmente se incide es sobre la actividad bursátil del inversor, que es la que realmente se dirige a satisfazer necessidades concretas, y la que se ve mermada por la desconfianza de los inversores hacia el mercado." (Op. cit., p. 330331)

${ }^{306}$ Acerca do tema, esclarece Siegfried Kümpel: "Deve ser considerado, entretanto, o fato de que o termo 'proteção do investidor' tem um duplo sentido e pode facilmente induzir a equívocos. Assim, esse termo somente pode significar a proteção do conjunto dos investidores (público investidor), o que também inclui aquelas pessoas que adquirirão valores mobiliários somente no futuro (investidores em potencial). Por isso, a Lei das Bolsas de Valores alemã utiliza o termo 'público'. A proteção do investidor também pode significar a proteção dos interesses individuais de cada investidor. Devido às implicações jurídicas diferentes, a proteção individual deve ser estritamente diferenciada da proteção do público investidor, pois uma obrigação de indenizar somente pode ocorrer onde existir uma disposição destinada a proteger os interesses individuais do investidor lesado." (Op. cit., p. 36-37)
} 
Está-se diante, pois, de um bem jurídico supra-individual. Acerca de tal conceituação, vale transcrever o entendimento de Siegfried Kümpel, a corroborar o alcance da tutela e sua relevância:

A proteção do público por intermédio do Direito do Mercado de Capitais também significa a proteção do conjunto numericamente indeterminado de todos os investidores atuais e futuros. Do ponto de vista do Mercado de Capitais, o termo 'público' engloba toda a oferta e demanda. Tal potencial (de compra e venda) dos investidores é de grande importância para a liquidez do Mercado de Capitais e, por conseguinte, para a sua capacidade funcional. ${ }^{307}$

Em idêntico sentido, Luis Ramon Ruiz Rodriguez:

Não se trata, sem dúvida, da atividade de cada sujeito investidor individualmente considerado, mas, desde uma concepção geral supraindividual, da atuação no mercado como forma de participação nos mecanismos sociais de distribuição de riqueza. ${ }^{308}$

Cumpre destacar que o bem jurídico supra-individual ora apontado, em momento algum se afasta da proposta da teoria pessoal do bem jurídico ora adotada. Há que se ter em conta, consoante expõe Sternberg-Lieben, que "as necessidades do indivíduo para o desenvolvimento de sua pessoa não se limitam à lista de bens jurídicos individuais. O indivíduo deve ser considerado não como um, mas como uma individualidade social, como sujeito integrado à comunidade e, por esta razão, o conceito pessoal de bem jurídico abarca bens que surgem e cobram importância com o contato social". 309

Ademais, quanto a um juízo de proporcionalidade, a eleição dos interesses patrimoniais dos investidores como bem juridicamente protegido parece também adequada, tendo em vista que o papel exercido pelo público investidor para o desenvolvimento econômico e o funcionamento do sistema social possui a relevância exigível para que lhe seja dispensada proteção penal, na medida em que sua afetação provoca um dano social cuja gravidade justifica a intervenção do direito penal, restando, pois, atendidos os critérios de fragmentariedade e necessidade - idoneidade para alcançar o fim procurado e subsidiariedade.

\footnotetext{
${ }^{307}$ Idem, p. 37

308 Tradução nossa: "No se trata, sin embargo, de la actividad de cada sujeto inversor individualmente considerado, sino, desde una concepción general supraindividual, de la actuación en el mercado como forma de participación en los mecanismos sociales de distribución de la riqueza.” (Op. cit., p. 331)

309 Op. cit., p. 110-111, tradução nossa.
} 
Diante do exposto, se procurou, por meio da análise das teorias defendidas pela doutrina estrangeira, delinear um bem jurídico sistematizado para os crimes contra o Mercado de Capitais, ao que se conclui, ante uma proposta de bem jurídico nos moldes da teoria pessoal desenvolvida por Hassemer - necessariamente vinculada a interesses individuais e voltada para a garantia da dignidade humana - que o interesse patrimonial dos investidores é o único bem que reúne condições para tanto, devendo, portanto, funcionar como limitador da intervenção penal do Estado no âmbito dos ilícitos praticados contra o Mercado de Capitais, cumprindo aos instrumentos de regulação administrativa a adequada proteção do correto funcionamento do mercado.

\subsection{A construção típica}

Uma vez identificado o bem jurídico protegido nos crimes contra o Mercado de Capitais, se tratará de analisar a construção típica adotada pelo legislador brasileiro; assumindo-se, desde logo, uma postura crítica com relação a uma tendência verificada na legislações penais especiais no Brasil quanto à utilização de tipos excessivamente abertos.

Faz-se necessária, ademais, uma reflexão crítica no tocante à opção legislativa pela utilização de crimes de perigo abstrato, tema dos mais controversos no debate dogmático atual.

\subsubsection{Tipos em espécie}

Quanto aos tipos penais inseridos na Lei do Mercado de Capitais pela Lei $10.303 / 2001$, optou-se no presente trabalho por se fazer uma análise crítica daqueles relacionados às operações propriamente ditas. Dentro de tal contexto, serão estudados os crimes de manipulação de mercado (art. 27-C da Lei 6.385/76) e uso indevido de informação privilegiada, ou insider trading (art. 27-D da Lei 6.385/76). Em decorrência da opção aqui adotada, se deixou de analisar o crime de exercício irregular de cargo, profissão, atividade ou função, previsto no artigo 27-E da Lei do Mercado de Capitais. 


\subsubsection{Manipulação de mercado}

Dispõe o artigo 27-C da Lei 6.385/76, acrescentado ao texto legal pela reforma do Mercado de Capitais ocorrida em 2.001, que será apenada com reclusão de um a oito anos a realização de operações simuladas ou execução de outras manobras fraudulentas, com a finalidade de alertar artificialmente o regular funcionamento do mercado de valores mobiliários, com a finalidade de obtenção de vantagem indevida ou lucro, para si ou para outrem, ou causar dano a terceiros. ${ }^{310}$

Quanto ao conceito de manipulação de mercado, segundo aponta Thomas Lee Hazen, o entendimento firmado pelos tribunais norte-americanos foi o mais estreito possível, limitando-o a um sentido de manipulação de preços. Em outras palavras, trata-se da adoção de práticas que visam a alterar a lei natural da oferta e demanda. ${ }^{311}$

No mesmo sentido apontam Modesto Carvalhosa e Nelson Eizirik, ao afirmarem que "a manipulação caracteriza tipicamente um processo de formação artificial de preços, um 'falso mercado' e, consequentemente, agride o funcionamento regular do Mercado de Capitais". 312

Nesse contexto, as práticas passíveis de serem consideradas como manipulação de mercado estão adstritas ao chamado mercado secundário; na medida em que o processo de formação de preços (cotações) dos valores mobiliários se dá justamente dentre deste âmbito de negociação. Vale lembrar que no mercado primário, consistente no lançamento de valores mobiliários pelas companhias emissoras, o valor das cotações dos papéis se dá por meio de critérios legais pré-determinados. ${ }^{313}$ Dessa forma, o tipo penal

\footnotetext{
310 “Art. 27-C. Realizar operações simuladas ou executar outras manobras fraudulentas, com a finalidade de alterar artificialmente o regular funcionamento dos mercados de valores mobiliários em bolsa de valores, de mercadorias e de futuros, no mercado de balcão ou no mercado de balcão organizado, com o fim de obter vantagem indevida ou lucro, para si ou para outrem, ou causar dano a terceiro. Pena - reclusão, de 1 (um) a 8 (oito) anos, e multa de até 3 (três) vezes o montante da vantagem ilícita obtida em decorrência do crime."

${ }^{311} \mathrm{E}$ complementa o autor norte-americano: "Manipulative conduct is not limited to conduct that actualy causes a rise (or fall) in the stock price. It includes conduct that retards a decline in price that would otherwise result form supply and demand forces". Principles of securities regulation. $2^{\mathrm{a}} \mathrm{ed}$. St. Paul: Thomson/West, 2005, p. 248-249. "As práticas manipuladoras susceptíveis de integrar o tipo de crime podem traduzir-se em manipulação no sentido de subida dos preços, no sentido da descida dos preços e, inclusivamente, no sentido da sustentação artificial do preço de um activo". (PINTO, Frederico de Lacerda da Costa. Op. cit., p. 91)

${ }^{312}$ A nova Lei das S/A. Op. cit., p. 534

${ }^{313}$ Como exemplo, o parágrafo primeiro do artigo 170 da Lei das Sociedades Anônimas estabelece os parâmetros de fixação inicial da cotação das ações para lançamento em mercado.
} 
não se aplica a negociações ocorridas fora do mercado secundário, tendo o texto legal tratado de limitar expressamente o âmbito de alcance da proibição, à alteração artificial do regular funcionamento "dos mercados de valores mobiliários em bolsa de valores, de mercadorias e futuros, no mercado de balcão ou no mercado de balcão organizado".

Pois bem, as condutas típicas incriminadas no referido artigo 27-C são as de 'realizar operações simuladas' e 'executar outras manobras fraudulentas'. Dessa forma, a simulação ou a fraude são elementos essenciais do tipo penal, sem os quais não se configura o crime.

De plano, cumpre ressalvar que o conceito de operações é por demais aberto, aplicável a diversos significados. Dessa forma, para fins de uma tutela penal adequada a sua função de intervenção mínima e subsidiária, resta relevante tentar delimitar tal conceito, buscando-se, dessa forma, maior respeito ao princípio da taxatividade. Nesse compasso, parece adequado o entendimento firmado por Alexandre Brandão da Veiga, o qual procura, por meio de uma posição cautelosa, delimitar o conceito de operações para efeitos do crime de manipulação de mercado em três grupos distintos.

Em primeiro plano, encontram-se os "negócios transmissivos de valores mobiliários ou instrumentos financeiros", núcleo central do conceito de operações, vale dizer, efetivas transações de valores mobiliários e instrumentos financeiros no mercado. São, nos dizeres do autor português, "as operações por natureza". 314

O segundo grupo de operações apontadas pelo autor consistem em "negócios criadores de instrumentos financeiros". Tratam-se, aqui, de negócios que, mesmo realizados fora de mercado organizado, e não considerados como operações, como empréstimos, por exemplo, "são convolados em operações pela sua imputação em mercado". 315

\footnotetext{
${ }^{314}$ Crime de manipulação, defesa e criação de mercado.Coimbra: Almedina, 2001, p. 49-50

${ }^{315}$ Assim define o autor português: “[...] os negócios criadores de instrumentos financeiros estão incluídos neste conceito. É sabido que nos instrumentos financeiros a dimensão de criação (estrutural) e de transmissão (funcional) são por vezes temporal e/ou logicamente incindíveis. Criar um futuro tem por vezes pequena diferença em relação à sua transmissão. Por outro lado, muitos negócios que, quando realizados fora de mercado organizado não se podem considerar operações (é o caso dos empréstimos, por exemplo) são convolados em operações pela sua imputação em mercado". (Idem, p. 50)
} 
Por fim, remete a "operações realizadas em mercado organizado como tal qualificadas por Lei" como o terceiro e último grupo integrante do conceito de operação, e ressalva a dificuldade de se lidar com conceitos dogmáticos pouco sedimentados, aos quais apenas se pode remeter. ${ }^{316}$

De qualquer forma, deve se ter em conta por operações, os negócios efetivamente concluídos, ficando excluídas as ofertas, propostas negociais e todos os aspectos preliminares à negociação.

A simulação, por seu turno, consiste no disfarce, no simulacro, no mis en scéne. Alexandre Brandão da Veiga aponta que as operações são consideradas fictícias no âmbito do Mercado de Capitais porque:

a) Do próprio conteúdo funcional do negócio resulta que não se pretende que tenha vida funcional. Mais concretamente, e dando um exemplo, não se pretende que o contrato seja cumprido. Se dele decorrer o dever de entrega ou transferência de valores mobiliários e o de pagamento de preço desde o início não se pretende que os valores sejam entregues ou o preço seja pago;

b) Mais geralmente, existe um desvio entre o nexo genético e o funcional na operação em causa. Pode ser que haja real transferência de valores e de dinheiro, mas não há reais translações patrimoniais, ou havendo-as, ocorrem em moldes diferentes dos que são plasmados no negócio. ${ }^{317}$

Poder-se-ia questionar pela inaplicabilidade do conceito de operações fictícias, tendo em vista que se tratam de negócios efetivamente realizados, especialmente quando se trata de operações realizadas em bolsa de valores, onde a transferência de titularidade e de dinheiro são obrigatórias. Contudo, consoante aponta Frederico de Lacerda da Costa Pinto, "o que está em causa nos negócios de natureza fictícia não é, evidentemente, a sua existência real, mas seu significado", posto que "a manipulação só surge como uma prática lesiva para o mercado e para os investidores porque os negócios celebrados existem efectivamente, mas não significam aquilo que aparentam". 318

\footnotetext{
${ }^{316}$ Ibidem

${ }^{317}$ Op. cit., p. $50-51$

${ }^{318}$ Op. cit., p. 88
} 
Já no tocante à fraude, trata-se do artifício ardiloso por meio do qual se busca forjar uma aparência falsa da realidade. ${ }^{319}$ Nesse contexto, simulação e fraude são figuras bastante semelhantes, podendo-se afirmar que a simulação é espécie do gênero fraude.

Alexandre Brandão da Veiga aponta como práticas fraudulentas aquelas que acarretam o perigo abstrato de enganar terceiro, induzindo-os em erro. ${ }^{320}$ Já Thomas Lee Hazen ressalva a necessidade, no sistema norte-americano, da existência de um dano concreto. ${ }^{321}$ De qualquer forma, o conceito de outras manobras fraudulentas expresso no tipo penal vem a ser subsidiário ao de operações simuladas.

Assim, o crime de manipulação de mercado abrange condutas "que se traduzem em operações aparentemente regulares mas que, na realidade, são controladas pelos agentes de forma a violar o livre jogo da oferta e da procura", vale dizer, "criam uma aparência de liquidez ou geram cotações que, por estarem artificialmente sustentadas, não correspondem à realidade". ${ }^{322}$

Ademais, as condutas manipuladoras devem estar dotadas de idoneidade, vale dizer, devem ser aptas a alterar o regular funcionamento do mercado. Nesse aspecto, o

319 “A fraude, segundo Cortese, "é o processo psíquico de dissimulações adotado como meio para alcançar um fim que é o erro de outrem'”. (La struttura della truffa, Nápoles, 1968, p. 22. Apud. REALE JÚNIOR, Miguel. Direito penal aplicado. V. 4. São Paulo: Revista dos Tribunais, 1994, p. 130)

320 Op. cit., p. 61-62

321 "Also, as in the case with any fraud claim, the plaintiff must be able to establish damages. In most Rule 10b-5 litigation, the appropriate measure of damages is the out-of-pocket loss proximately caused by the material misstatement or omission. Depending on the facts, other measures, such as benefit of the bargain may be appropriate". (Op. cit., p. 259) Ainda, sobre o conceito de fraude para o direito norte-americano: "Fraud: A knowing misrepresentation of the truth or conclealment of a material fact to induce another to act to his or her detriment; (...) Fraud on the market: fraud occuring when an issuer of securities gives out misinformation that affects the market price of stock, the result being that people who buy or sell are effectivelly misled even though they did not rely on the statement itself or anything derived form it other than the market price." (GARNER, Bryan A. A dictionary of criminal law terms. St. Paul: Thomson/West, 2006, p. 280 e 282)

${ }^{322}$ PINTO, Frederico de Lacerda da Costa. Op. cit., p. 87. Vale aqui citar o exemplo dado por Modesto Carvalhosa e Nelson Eizirik: "se duas instituições financeiras combinam que uma trocará com a outra posições acionárias para gerar uma impressão de liquidez dos papéis, ou para aumentar-lhes a cotação, há operações simuladas, pretensamente reais, mas que não ocorrem de acordo com as regras de oferta e procura. Ou seja, simulam-se operações de compra e venda a mercado, quando se trata de operações previamente acordadas". (A nova Lei das S/A. Op. cit., p. 536) "Common examples of manipulation include wash Sales and matched orders. A wash sale is a fictious sale where there is no change in beneficial ownership and thus no true economic consequence. A matched order ocours when orders are entered simultaneously to by and sell the same security. Another manipulative practice is known as 'parking', which consists of transferring record ownership of securities in order to hide the true identity of the beneficial owner. A planned series of 
legislador português tratou de expressamente incluir tal condição no tipo penal, mediante a expressão "idôneas para alterar artificialmente o regular funcionamento do mercado de valores mobiliários ou de outros instrumentos financeiros". 323

No tocante ao elemento subjetivo, a redação do tipo penal evidencia que o dolo destas condutas deve ser o específico, ou seja, o agente deve ter o fim especial de alterar artificialmente o funcionamento regular do mercado com o fim de obter vantagem ou causar dano. Assim, não se incriminam condutas culposas ou cometidas com fim diverso ao de modificar de forma artificial o funcionamento do mercado.

Por exemplo, caso uma companhia divulgue informação errada em seu balanço, que gere alteração do valor de suas ações no mercado mobiliário e consequente vantagem pecuniária, não estará caracterizado o crime na hipótese de a informação errada ter sido aposta no balanço por erro de digitação.

Outro exemplo é o citado por Modesto Carvalhosa e Nelson Eizirik:

[...] se o agente negocia uma grande quantidade de títulos, num pequeno período de tempo, pode provocar a alteração da cotação de tais valores, sem a intenção de manipular; é o que ocorre nas operações que, por seu volume, causam um 'impacto de mercado', que não se confunde com manipulação, pela ausência do dolo específico. ${ }^{324}$

A grande dificuldade que o Direito Penal enfrentará é a de reconhecer e distinguir a fraude ou simulação da operação lícita e, principalmente, diferenciar o dolo de alterar artificialmente o mercado da intenção lícita de obtenção de lucros por meio de operações regulares no mercado, quanto mais se levado em conta que o risco é uma das características inerentes ao Mercado de Capitais.

purchases of securities that is specifically designed to artificially restrict the supply and thereby raise prices is a manipulation. (Op. cit., p. 249)

${ }^{323}$ Artigo $379^{\circ}, \mathrm{n}^{\circ} 1$ do Código de Valores Mobiliários português. Acerca do tema vide: PINTO, Frederico de Lacerda da Costa. Op. cit., p. 89 e ss. VEIGA, Alexandre Brandão da. Op. cit., p. 65-67. No mesmo sentido: "O meio executivo deve ser apto para provocar a falsa cotação dos papéis, ou para enganar a vítima. Havendo ineficácia absoluta do meio ou absoluta impropriedade do objeto, verifica-se o crime impossível (art. 17 do Código Penal)". (CARVALHOSA, Modesto; EIZIRIK, Nelson. Op. cit., p. 538). Cumpre ressalvar que o tema em questão será melhor desenvolvido quando da análise da aplicabilidade dos crimes de perigo abstrato em apartado seguinte.

${ }^{324}$ A nova Lei das S/A. Op. cit., p. 539. 
Importante ressaltar que o crime de manipulação de mercado pode ser praticado por qualquer pessoa que atue no mercado; isto é, trata-se de crime comum, podendo ser praticado por acionistas, administradores, operadores de instituições financeiras, de distribuidoras ou de corretoras de títulos mobiliários etc. ${ }^{325}$, que se consuma com a efetiva realização de operação simulada ou com a execução de manobras fraudulentas que objetivem alterar o regular funcionamento do mercado. ${ }^{326}$

Deve-se ainda chamar atenção para a pena cominada ao delito, de 1 a 8 anos e multa, que deixa ao juiz uma enorme margem de liberdade para a fixação da pena na sentença. Liberdade que deve ser exercida com observância aos ditames do art. $59^{327}$ do Código Penal. Trata-se aqui de patente quebra do princípio da proporcionalidade, haja vista que a pena máxima cominada é oito vezes superior à pena mínima, naquela que talvez seja a maior margem existente na legislação penal brasileira. Nesse contexto, relevante consignar a posição de Mariângela Gama Magalhães Gomes:

[...] a fim de que seja respeitado o imperativo da individualização da pena ao caso concreto, impõem-se que as penas devem, necessariamente, ser discricionárias, cabendo ao órgão julgador adequar a pena in abstrato às características do delito e às qualidades do seu agente. No entanto, não obstante a necessidade de conferir ao intérprete legal a possibilidade de ajustar a lei ao caso concreto, a margem legal fornecida pelo legislador não pode ser excessivamente discricionária, de modo a consentir que o poder do juiz substitua a escolha reservada ao legislador. [...] Assim, se a margem existente entre as penas máxima e mínima for demasiadamente ampla (o que também ocorre nas hipóteses de inexistência de limites máximo ou mínimo), torna-se ela inidônea para evidenciar a escolha legislativa quanto à gravidade abstrata do delito não apenas a gravidade abstrata da conduta incriminada carece de significado valorativo, como o próprio legislador 'confessa' implicitamente que inseriu num único tipo penal hipóteses criminosas de gravidade visivelmente diversas -, e o juiz, quando da determinação

\footnotetext{
${ }^{325}$ Vale apontar que o Código Penal, em seu artigo 177, §, prevê o crime de falsa cotação de ações ou títulos da sociedade, tratando-se de crime próprio, do qual somente poderão ser sujeitos ativos o diretor, gerente ou fiscal de sociedade por ações.

326 PAULA, Áureo Natal de. Crimes contra o Sistema Financeiro Nacional e o Mercado de Capitais. Curitiba: Juruá, 2006, p. 20

327،A Art. 59. O juiz, atendendo à culpabilidade, aos antecedentes, à conduta social, à personalidade do agente, aos motivos, às circunstâncias e conseqüências do crime, bem como ao comportamento da vítima, estabelecerá, conforme seja necessário e suficiente para reprovação e prevenção do crime:

I - as penas aplicáveis dentre as cominadas;

II - a quantidade de pena aplicável, dentro dos limites previstos;

III - o regime inicial de cumprimento da pena privativa de liberdade;

IV - a substituição da pena privativa de liberdade aplicada, por outra espécie de pena, se cabível."
} 
concreta da pena, acaba substituindo a valoração legislativa, violando, desta forma, o princípio da reserva de lei. ${ }^{328}$

Aplica-se cumulativamente à pena privativa de liberdade pena de multa que pode chegar a três vezes o valor do benefício indevido auferido ou do prejuízo causado por conta das práticas de manipulação de mercado.

Por fim, trata-se de crime de ação penal pública, sujeito ao benefício legal da suspensão condicional do processo, previsto no artigo 89 da Lei 9.099/95, uma vez que a pena mínima cominada é de reclusão de um ano.

\subsubsection{Uso indevido de informação privilegiada: Insider Trading}

O artigo 27-D, acrescentado pela Lei 10.303/2001 à Lei do Mercado de Capitais, dispõe que será apenada com reclusão de um a cinco anos e multa de até três vezes o valor do benefício indevido ou do prejuízo causado, a utilização de informação relevante ainda não divulgada ao mercado, de que tenha o agente conhecimento e da qual deva manter sigilo. ${ }^{329}$

Consoante visto anteriormente no presente trabalho, a informação assume relevante papel para o regular funcionamento do Mercado de Capitais e à proteção dos interesses patrimoniais dos investidores, na medida em que se revela como fator essencial na determinação da justa cotação dos valores mobiliários negociados em mercado ${ }^{330}$, sendo, portanto, resguardada pelo princípio da transparência (disclosure), informador de todo o Direito do Mercado de Capitais e sua respectiva regulação.

Contudo, não é qualquer informação que pode ser objeto do crime de insider trading, mas sim a chamada informação privilegiada. Destaque-se, contudo, pela

\footnotetext{
${ }^{328}$ O princípio da proporcionalidade no direito penal. São Paulo: Revista dos Tribunais, 2003, p. 165-16

329 “Art. 27-D. Utilizar informação relevante ainda não divulgada ao mercado, de que tenha conhecimento e da qual deva manter sigilo, capaz de propiciar, para si ou para outrem, vantagem indevida, mediante negociação, em nome próprio ou de terceiro, com valores mobiliários.

Pena - reclusão, de 1 (um) a 5 (cinco) anos, e multa de até 3 (três) vezes o montante da vantagem ilícita obtida em decorrência do crime."

330 "Considera-se, na teoria econômica, que o mercado é eficiente quando a cotação das ações reflete, de forma virtual e instantânea, todas as informações disponíveis sobre as companhias cujos títulos são publicamente negociados". (CARVALHOSA, Modesto; EIZIRIK, Nelson. Op. cit., p. 544)
} 
inexistência de uma conceituação precisa do que vem a ser informação privilegiada, motivo pelo qual se deverá apelar à doutrina e ao direito comparado, para a obtenção de uma precisa definição.

Segundo conceituado no Dicionário de Finanças on line da Bolsa de Valores de São Paulo, atual BM\&FBOVESPA, informação relevante é aquela:

Referente a fatos, ocorridos nos negócios da companhia, que possam influir, de modo ponderável, na decisão dos investidores do mercado, de vender ou comprar valores mobiliários de sua emissão. ${ }^{331}$

No tocante à regulação estrangeira, merece especial destaque a Diretiva 2003/6/CE do Parlamento Europeu, que em seu considerando 16 conceitua informação privilegiada como:

[...] toda a informação com carácter preciso, que não tenha sido tornada pública e diga respeito, directa ou indirectamente, a um ou mais emitentes de instrumentos financeiros ou a um ou mais instrumentos financeiros. Uma informação, que possa ter um efeito significativo sobre a formação e evolução dos preços de um mercado regulamentado enquanto tal, poderá ser considerada como uma informação indirectamente relacionada com um ou mais emitentes de instrumentos financeiros ou com um ou mais instrumentos financeiros derivados com eles relacionados.

Denota-se, pois, dos conceitos ora transcritos, que informação relevante vem a ser qualquer informação relacionada à administração ou à atividade das companhias emissoras, que seja capaz de influenciar no valor dos valores mobiliários ou na decisão dos investidores em exercer seus direitos de titularidade sobre tais valores.

A partir de sua delimitação, o conceito de informação privilegiada pode ser decomposto em parâmetros necessários, os quais deverão concorrer simultaneamente para a configuração da informação como privilegiada.

O primeiro destes parâmetros diz respeito às características da informação, notadamente, que seja concreta, relevante e ainda não levada ao conhecimento do público.

${ }^{331}$ http://www.bovespa.com.br/Principal.asp - consultado em 10 de dezembro de 2008 
Por informação concreta, ou precisa, deve se entender aquela que tenha por objeto um fato já ocorrido ou que pode ocorrer em um futuro não muito distante, que tenha um objeto determinado e que possa ser descrito, situado no tempo e no espaço e atribuído a um sujeito. ${ }^{332}$

A Diretiva 2003/124/CE do Parlamento Europeu, que estabelece as modalidades de aplicação da Directiva 2003/6/CE no que diz respeito à definição e divulgação pública de informação privilegiada e à definição de manipulação de mercado, assim dispõe:

Cconsidera-se que uma informação possui um carácter preciso se fizer referência a um conjunto de circunstâncias existentes ou razoavelmente previsíveis ou a um acontecimento já ocorrido ou razoavelmente previsível e se essa informação for suficientemente precisa para permitir retirar uma conclusão quanto ao eventual efeito desse conjunto de circunstâncias ou acontecimentos a nível dos preços dos instrumentos financeiros ou dos instrumentos financeiros derivados com eles relacionados. ${ }^{333}$

Frederico de Lacerda da Costa Pinto, por sua vez, apregoa que:

A exigência legal de a informação ser precisa significa, na minha opinião, que a informação deve ter em relação à realidade que descreve um mínimo de materialidade ou objectividade ou, noutros termos, a consistência mínima para permitir a sua utilização por um investidor médio. ${ }^{334}$

Ponderação relevante é feita por Faria Costa e Maria Elisabete Ramos, os quais apontam para a extrema dificuldade de se determinar a precisão de uma informação, especialmente na hipótese de negociações complexas e demoradas envolvendo companhias emissoras, como, por exemplo, nos casos de fusão e aquisição, que envolvem momentos diversos, como estudos, entrevistas, trocas de informações sigilosas e documentos. Nesse passo, o problema reside especialmente na chamada fase pré-contratual. Como possível

\footnotetext{
${ }^{332}$ HERNÁNDEZ SAINZ, Esther. Op. cit., p. 309

${ }^{333}$ Artigo 1.1

${ }^{334}$ Op. cit., p. 77. Monroy Antón, por sua vez, adota um conceito menos rígido de informação concreta. Para o autor espanhol, a concreção da informação não deve se referir ao grau de perfeição ou de finalização da informação, mas sim à possibilidade de verificação da mesma, o que ocorre com projetos futuros de uma sociedade, mas não com rumores ou conjecturas. (Op. cit., p. 61). Esther Hernández Sainz inclui no conceito de informação concreta as denominadas soft informations, ou seja, aquelas relativas a fatos ou circunstâncias que se pode esperar razoavelmente sejam produzidos no futuro. (Op. cit., p. 306)
} 
solução, recorrem os autores a conceitos do direito civil, para delimitarem as duas fases do processo pré-contratual, a primeira, eminentemente negociatória, estágio embrionário da vontade e que envolve uma série de atos não vinculantes, e uma segunda, de cunho decisório, representada pela apresentação de uma proposta e a correspondente definição quanto a sua aceitação. Com base nos citados elementos, concluem de forma precisa:

Não nos oferece dúvidas que o acordo entre as partes representa um grau de consolidação e de 'cristalização que permite, em sede de informação privilegiada, afirmar que o conhecimento de tal acordo constitui informação precisa. Contudo, pensamos que a intencionalidade do crime de abuso de informação autoriza-nos a sustentar que, no decurso de um processo negocial, a informação atinge o grau de consolidação ou cristalização tipicamente relevante para efeitos de crime de uso de informação quando a probabilidade de o acordo não se fechar for ínfima ou irrisória. ${ }^{335}$

Desta feita, é inegável que para a adequação ao tipo penal do insider trading a informação tenha que ser precisa, factível e possível de ser verificada quanto ao seu conteúdo. Evidentemente, caberá ao intérprete da Lei, em face do caso concreto, analisar o conteúdo da informação e suas específicas circunstâncias espaço-temporais. ${ }^{336}$ De qualquer forma, com a exigência de concretude em relação à informação, afasta-se a possibilidade de criminalização em face de rumores, conjecturas, informações genéricas ou notícias difusas, implicando em maior segurança jurídica ao sistema. ${ }^{337}$

A segunda das características da informação relevante diz respeito à sua relevância, isto é, que seja idônea a afetar de forma significativa o valor das cotações e, consequientemente, passível de implicar em benefício indevido ou prejuízo a terceiros. ${ }^{338}$

Consoante conceitua Esther Hernández Sainz:

\footnotetext{
${ }^{335}$ Op. cit., p. $49-50$

${ }^{336}$ HERNÁNDEZ SAINZ, Esther. Op. cit., p. 305

${ }^{337}$ Esther Hernández Sainz acrescenta ainda as estatísticas e pesquisas de opinião informações que não podem ser consideradas concretas, na medida em que se tratam de mero sistema de valoração, uma fórmula para analisar a realidade, mas não uma circunstância ou um fato que se tenha dado na realidade ou que se pode esperar razoavelmente que se produza. (Op. cit., p. 317-318)

${ }^{338}$ Trata-se de conceito derivado do direito norte-americano, no qual prevalece a noção de materiality, assim definida por Thomas Lee Hazen: "The Supreme Court has defined materiality in terms of the type of a information that a reasonable investor would consider significant in making an investment decision. The materiality particular item is based on a highly factual inquiry and is to be determined within the total mix of information that is publicly availible. [...] The test of materiality depends not upon the literal truth of statements, but upon the ability of reasonable investors to become accurately informed". (Op. cit., p. 258266)
} 
Desde uma perspectiva econômica, uma informação é relevante com relação à negociação de um bem qualquer quando seu conhecimento pode alterar o equilíbrio existente entre a oferta e a demanda. No âmbito do mercado de valores mobiliários, informação relevante é aquela capaz de gerar um resposta no mercado. É uma informação que permite ao investidor realizar uma melhor eleição. É o elemento que mede o valor da informação, posto que quanto mais relevante seja a informação, maiores serão as possibilidades de benefício derivadas de sua utilização. ${ }^{339}$

A diretiva 2003/124/CE, uma vez mais, tratou de apontar uma conceituação quanto a informação relevante;

Entende-se por 'informação que, caso fosse tornada pública, seria susceptível de influenciar de maneira sensível o preço dos instrumentos financeiros ou dos instrumentos financeiros derivados com eles relacionados', a informação que um investidor razoável utilizaria normalmente para basear em parte as suas decisões de investimento. ${ }^{340}$

Para a verificação da relevância da informação, deve-se fazer um juízo de comparação entre o uso da informação e os efeitos possíveis relativos à reação do mercado. Não se trata de tarefa fácil, e cujos resultados podem ser altamente questionáveis, posto que a informação não é o único fator decisivo na formação das cotações, bem como, nem todos os investidores tomam suas decisões com base em informações já publicadas. ${ }^{341}$

De qualquer forma, não se pode ignorar que a utilização da informação privilegiada tenha necessariamente que apresentar, ao menos, um potencial lesivo. Assim, a investigação acerca da relevância da informação deverá ser feita por meio de um juízo ex ante, ou seja, deve-se retroagir até o momento anterior ao da divulgação da informação, aferindo-se se tal era capaz de influenciar na decisão dos investidores, alterando significativamente o valor das cotações. Ademais, cabem meios de investigação para uma avaliação do momento posterior à divulgação da informação (ex post); o que a doutrina norte-americana denomina de actual market impact, verificando-se quais os efeitos que a divulgação da informação teve no mercado, eventuais vantagens econômicas obtidas pelo

\footnotetext{
${ }^{339}$ Traduzido do original. Op. cit., p.362

${ }^{340}$ Artigo 1.2

341 “O requisito relativo à idoneidade levanta particulares dificuldades para o intérprete/aplicador da lei. Não é tanto a dificuldade de avaliar uma conduta passada - ao fim e ao cabo circunstância comum a todo o julgamento institucionalizado - mas antes a volatilidade dos valores mobiliários a implicar diversas variações na cotação dos títulos”. (COSTA, José Francisco de Faria; RAMOS, Maria Elisabete. Op. cit., p. 53)
} 
insider. Outros dados capazes de orientar a averiguação da idoneidade da informação são o nível de segredo com que tal informação era tratada pela companhia emissora e a credibilidade da fonte. ${ }^{342}$

Outro fator a contribuir para a análise da relevância da informação vem a ser o conceito de fato ou ato relevante. A instrução CVM n. ${ }^{\circ} 358 / 02$, por sua vez, em seu $\operatorname{artigo} 2^{\circ}$, define o que vem a ser ato ou fato relevante como:

[...] qualquer decisão de acionista controlador, deliberação da assembléia geral ou dos órgãos de administração da companhia aberta, ou qualquer outro ato ou fato de caráter político-administrativo, técnico, negocial ou econômico-financeiro ocorrido ou relacionado aos seus negócios que possa influir de modo ponderável: I - na cotação dos valores mobiliários de emissão da companhia aberta ou a eles relacionados; II - na decisão dos investidores de comprar, vender ou manter aqueles valores mobiliários; III - na decisão dos investidores de exercer quaisquer direitos inerentes à condição de titular de valores mobiliários emitidos pela companhia ou a eles referenciados.

O parágrafo único do artigo em comento ainda traz vinte e dois exemplos de atos ou fatos considerados como relevantes. Todavia, referido rol não é taxativo, mas sim, conforme expresso no próprio texto, meramente exemplificativo. ${ }^{343}$

\footnotetext{
${ }^{342}$ PINTO, Frederico de Lacerda da Costa. Op. cit., p. 78-80. HERNÁNDEZ SAINZ, Esther. Op. cit., p. 376 e ss.

343 "Parágrafo único. Observada a definição do caput, são exemplos de ato ou fato potencialmente relevante, dentre outros, os seguintes: I - assinatura de acordo ou contrato de transferência do controle acionário da companhia, ainda que sob condição suspensiva ou resolutiva; II - mudança no controle da companhia, inclusive através de celebração, alteração ou rescisão de acordo de acionistas; III - celebração, alteração ou rescisão de acordo de acionistas em que a companhia seja parte ou interveniente, ou que tenha sido averbado no livro próprio da companhia; IV - ingresso ou saída de sócio que mantenha, com a companhia, contrato ou colaboração operacional, financeira, tecnológica ou administrativa; V - autorização para negociação dos valores mobiliários de emissão da companhia em qualquer mercado, nacional ou estrangeiro; VI - decisão de promover o cancelamento de registro da companhia aberta; VII - incorporação, fusão ou cisão envolvendo a companhia ou empresas ligadas; VIII - transformação ou dissolução da companhia; IX - mudança na composição do patrimônio da companhia; X - mudança de critérios contábeis; XI - renegociação de dívidas; XII - aprovação de plano de outorga de opção de compra de ações; XIII - alteração nos direitos e vantagens dos valores mobiliários emitidos pela companhia; XIV - desdobramento ou grupamento de ações ou atribuição de bonificação; XV - aquisição de ações da companhia para permanência em tesouraria ou cancelamento, e alienação de ações assim adquiridas; XVI - lucro ou prejuízo da companhia e a atribuição de proventos em dinheiro; XVII - celebração ou extinção de contrato, ou o insucesso na sua realização, quando a expectativa de concretização for de conhecimento público; XVIII - aprovação, alteração ou desistência de projeto ou atraso em sua implantação; XIX - início, retomada ou paralisação da fabricação ou comercialização de produto ou da prestação de serviço; XX - descoberta, mudança ou desenvolvimento de tecnologia ou de recursos da companhia; XXI - modificação de projeções divulgadas pela companhia; XXII impetração de concordata, requerimento ou confissão de falência ou propositura de ação judicial que possa vir a afetar a situação econômico-financeira da companhia."
} 
Acerca do tema, Frederico de Lacerda da Costa Pinto faz relevante ressalva, ao afirmar que o critério do fato relevante é apenas mais um indício não exclusivo de idoneidade negocial da informação, posto que, caso contrário se violaria o princípio da fragmentariedade "que veda o recurso a ilações sistemáticas que desrespeitem a singularidade de cada tipo de ilícito". 344

Tome-se aqui por exemplo uma companhia de capital aberto que tenha como coligada uma sociedade de capital fechado. Ela celebra um acordo comercial que lhe trará relevante impacto nos resultados, mas que, no âmbito da empresa controladora não representa impacto expressivo. Tal fato, não obstante relevante do ponto de vista da controlada, não assume o mesmo papel com relação à controladora. Assim, pessoas ligadas à controladora e que no mesmo período tenham adquirido ações desta, não praticam o ilícito de uso de informação privilegiada, ante a patente inidoneidade da informação na formação do preço de suas cotações.

Outro aspecto que deve ser observado quanto à informação é que esta deve, necessariamente, ser desconhecida do público. Quanto ao tema, Monroy Antón aponta três interpretações possíveis. A primeira nada mais é do que uma interpretação literal do preceito, vale dizer, a informação torna-se pública no momento de sua divulgação. Uma segunda, no sentido de que a informação será pública somente quando analisada e assimilada pelo público. E uma terceira, intermediária, segundo a qual se requer um lapso de tempo desde a divulgação, a fim de que chegue ao maior número de investidores possíveis, mas que não dependa de uma análise detalhada. ${ }^{345}$ Parece claro aqui que para efeitos da tipificação do crime de insider trading, somente a primeira interpretação pode ser aceita, na medida em que, ante as características dinâmicas do Mercado de Capitais, qualquer interpretação que restrinja a negociações com valores a um lapso de tempo decorrido da divulgação decerto implicaria em incompatível engessamento do mercado.

Por fim, o segundo parâmetro para a configuração da informação privilegiada diz respeito à sua necessária vinculação com as companhias emissoras ou com

\footnotetext{
${ }^{344}$ Op. cit., p. $78-79$
}

${ }^{345}$ Op. cit., p. 63 
os próprios valores mobiliário; afastando-se, dessa forma, a criminalização em razão de meras notícias sobre determinado segmento econômico. ${ }^{346}$

Quanto ao elemento subjetivo, é consubstanciado pelo dolo específico, ante a exigência legal relativa ao fim especial de utilizar informação privilegiada com objetivo de lucro ou causação de prejuízos, restando, pois, isentas de incriminação as condutas culposas. Para a configuração do delito, é necessário que o sujeito utilize a informação privilegiada, negociando valores mobiliários, em nome próprio ou de terceiros, objetivando assim, auferir vantagem indevida, não sendo necessária a ocorrência de um resultado, consubstanciado no ganho econômico. Chega-se a essa conclusão em decorrência da utilização pelo legislador do termo "capaz de propiciar" vantagem indevida ou prejuízo a terceiros, tratando-se, dessa forma de crime formal ${ }^{347}$.

Verifica-se que o tipo penal em questão expressamente faz menção à quebra de um dever de sigilo do agente. Dessa forma, os sujeitos ativos serão aquelas pessoas obrigadas, por força de lei ou de contrato, a um dever de sigilo para com a informação.

Nesse sentido, o dever legal decorre da interpretação de diversos dispositivos da Lei das Sociedades Anônimas, ${ }^{348}$ segundo os quais são considerados como insiders: os administradores, diretores, membros do conselhos de administração e físcal e o acionista controlador das companhias abertas. ${ }^{349}$

\footnotetext{
${ }^{346}$ Conforme aponta Monroy Antón, especificamente quanto à legislação européia, esta, ao exigir que a informação deva ter relação também com instrumentos financeiros, acaba por caracterizar como informação privilegiada aquela referente a tipos de interesse ou qualquer outra variável macroeconômica, inclusive ao mercado em geral, pois este é composto por muitos instrumentos financeiros. (Op. cit., p. 62). Tal interpretação, todavia, não se aplica à norma penal brasileira, que faz menção restritiva a negociações com valores mobiliários.

${ }^{347}$ Em sentido contrário, Modesto Carvalhosa e Nelson Eizirik. A nova Lei das S/A. São Paulo: Saraiva, 2002 , p. 548.

348 "Art. 145. As normas relativas a requisitos, impedimentos, investidura, remuneração, deveres e responsabilidade dos administradores aplicam-se a conselheiros e diretores.

Art. 155. O administrador deve servir com lealdade à companhia e manter reserva sobre os seus negócios, sendo-lhe vedado:

[...]

$\S 4^{\circ}$ É vedada a utilização de informação relevante ainda não divulgada, por qualquer pessoa que a ela tenha tido acesso, com a finalidade de auferir vantagem, para si ou para outrem, no mercado de valores mobiliários. Art. 165. Os membros do conselho fiscal têm os mesmos deveres dos administradores de que tratam os arts. 153 a 156 e respondem pelos danos resultantes de omissão no cumprimento de seus deveres e de atos praticados com culpa ou dolo, ou com violação da lei ou do estatuto."

${ }^{349}$ No mesmo sentido: CARVALHOSA, Modesto; EIZIRIK, Nelson. Op. cit., p. 549
} 
Quanto ao dever contratual de sigilo, este decorre da prestação de serviços, contínua ou eventual, relacionados às atividades da companhia, inserindo-se nesse contexto os advogados, consultores, auditores e operadores do mercado que tenham porventura tido acesso à informação relevante, dentre outros. ${ }^{350}$

Conclui-se, pois, se tratar de crime próprio, o que não afasta a possibilidade de co-autoria, na medida em que o dever de sigilo se caracteriza como circunstância elementar do tipo penal, comunicando-se ao co-autor ou partícipe, consoante dispõe o artigo 30 do Código Penal.

Note-se que a instrução CVM 358/02, em seu artigo 13, elenca uma série de figuras, além da pessoa do administrador da companhia aberta, como proibidos de utilizar informações privilegiadas e sigilosas, e, ainda, no parágrafo $1^{\circ}$, estende o conceito de insider para qualquer pessoa que tenha conhecimento de informação referente a ato ou fato relevante, sabendo que se trata de informação não divulgada ao mercado. Referida norma administrativa faz especial menção àqueles agentes que tenham relação comercial, profissional ou de confiança com a companhia, como auditores, consultores e advogados. Trata-se, todavia, de norma de cunho administrativo, que não pode servir como integradora do tipo penal, sob pena de se violar o princípio da fragmentariedade.

Destaque-se que mesmo antes da criação, pela Lei 10.303/01, do tipo penal em estudo, o insider trading era detentor de certa previsão penal, por meio do crime de violação de segredo profissional, previsto no artigo 154 do Código Penal, tipo que não mais pode ser aplicado às hipóteses do Mercado de Capitais em razão de sua especialidade; restando, assim, resolvido eventual conflito aparente de normas.

Pode-se concluir, desse modo, que o legislador, com a criação do crime do artigo 27-D, além de conferir tratamento penal específico à matéria, cuidou de agravar as penas cominadas à conduta; não só pela majoração da restrição à liberdade, que no tipo do Código Penal é de seis meses a um ano de detenção, como também pela cumulação de multa, que pode chegar a três vezes o valor da vantagem econômica obtida.

${ }^{350}$ Idem. 
Tal como no crime de manipulação de mercado, trata-se de crime de ação penal pública, bem como, tendo em vista a pena mínima cominada, aplica-se a regra do artigo 89 da Lei 9.099/95 quanto à possibilidade de suspensão condicional do processo.

\subsubsection{Tipos abertos e crimes de perigo}

Uma vez identificado como bem juridicamente protegido o interesse patrimonial dos investidores, assim entendidos como o público investidor - composto pelos efetivos e potenciais investidores - este, consoante já afirmado, deve ser considerado como bem jurídico difuso $^{351}$ e, como tal, possui vínculo frágil e artificial com o sujeito respectivo.

Uma das principais características que cercam a criminalização dos novos riscos criados pela dinâmica da sociedade pós-moderna se configura na criação de tipos penais insuficientemente descritivos, o que significa a dificuldade de se compreender qual conduta constitui a proibição penal. Tradicionalmente, o tipo penal soergue a bandeira do princípio da legalidade, através da clareza e determinação das condutas nele descritas.

Essa técnica legislativa de indefinição dos tipos penais tem sido comum nos crimes que envolvem interesses difusos ou coletivos e, no entanto, não deve ser utilizada como o remédio mais eficaz para a proteção de bens jurídicos supra-individuais. Certamente não é pelo fato de ter o bem jurídico difuso vínculo fraco com o sujeito, e não possuir, na maioria das vezes, relação-base firme e determinada, que os bens jurídicos supra-individuais devam ser tutelados a partir de tipos penais também difusos e genéricos, nos quais o fundamento típico do injusto não é claramente determinado. É certo que o princípio nullum crimen, nulla poena sine lege certa continua tendo grande aplicação no

\footnotetext{
351 "O grupo dos interesses metaindividuais, o dos interesses difusos propriamente ditos, compreende interesses que não encontram apoio em uma relação-base bem definida, reduzindo-se o vínculo entre as pessoas a fatores conjunturais ou extremamente genéricos, a dados de fato freqüentemente acidentais e mutáveis: habilitar a mesma região, consumir o mesmo produto, viver sob determinadas condições sócioeconômicas, sujeitar-se a determinados empreendimentos etc. Tratam-se de interesses espalhados e informais à tutela de necessidades, também coletivas, sinteticamente referidas à qualidade de vida." (GRINOVER, Ada Pellegrini. A problemática dos interesses difusos. A tutela dos interesses difusos. São Paulo: Max Limonad, 1984. p.30 e ss.)
} 
sistema penal do brasileiro, e não pode admitir tais tipificações de cunho absolutamente autoritário, pois entregam ao magistrado a verdadeira caracterização do fato típico. ${ }^{352}$

Decerto, porém, que nem sempre o legislador conseguirá individualizar totalmente a conduta proibida, cabendo ao juiz este trabalho de interpretação com base em normas ou regras gerais externas ao direito penal. Trata-se aqui dos chamados tipos penais abertos, cuja utilização não necessariamente reflete uma inconstitucionalidade. ${ }^{353} \mathrm{O}$ problema reside, pois, na formulação de tipos excessivamente abertos.

Cumpre no presente estudo, analisar se tal cuidado foi empreendido pelo legislador na tipificação dos crimes contra o Mercado de Capitais.

No tocante ao crime de manipulação de mercado, verifica-se, de plano, certo cuidado quando da utilização da expressão "realizar operações simuladas". Como visto em apartado anterior, o conceito de operações no Mercado de Capitais, ${ }^{354}$ bem como o de operações simuladas, podem ser facilmente apreendidos pelo intérprete, não deixando margem de violação ao princípio da legalidade.

Já a utilização do termo "outras manobras fraudulentas" poderia dar margem a alguma discussão quanto a sua taxatividade. Contudo, parece tratar-se de conceito de aplicação subsidiária ao de "operações simuladas", não restando dúvida de que o conceito penal de fraude é facilmente compreendido. Quanto ao entendimento do termo "manobras", este deve ser compreendido no sentido de práticas. Nesse contexto, observa Alexandre Brandão da Veiga com muita propriedade, ao analisar a norma incriminadora portuguesa, dotada de expressão semelhante à utilizada pelo legislador brasileiro:

'Práticas' é um conceito valorativamente vazio, na medida em que tal possa ser afirmado de um conceito normativo. Em última análise identifica-se com 'condutas', ou seja com qualquer facto susceptível de integrar um tipo penal. A natureza vazia deste

\footnotetext{
${ }^{352}$ Consoante leciona Francisco de Assis Toledo: "A exigência de Lei certa diz com a clareza dos tipos, que não devem deixar margens a dúvidas nem abusar do emprego de normas muito gerais ou tipos incriminadores genéricos, vazios". (Princípios básicos de direito penal. $5^{\text {a }}$ ed. São Paulo: Saraiva, 2000, p. 29)

353 ZAFFARONI, Eugenio Raúl. PIERANGELI, José Henrique. Manual de direito penal brasileiro: parte geral. $4^{\mathrm{a}}$ ed. rev. São Paulo: Revista dos Tribunais, 2002, p. 447

${ }^{354}$ Nesse contexto o próprio legislador delimitou o alcance da expressão, ao referir expressamente a "regular funcionamento dos mercados de valores mobiliários em bolsa de valores, de mercadorias e futuros, no mercado de balcão ou no mercado de balcão organizado"
} 
elemento compreende-se numa dupla perspectiva. Funcionalmente, serve para definir este elemento como subsidiário em relação aos dois anteriores. Numa perspectiva de legitimação não padece de inconstitucionalidade na medida em que é preenchido com qualificações que o concretizam. ${ }^{355}$

No crime de uso indevido de informação privilegiada, por sua vez, no que diz respeito ao termo "informação relevante", a despeito de inexistir qualquer definição legal, de igual sorte, trata-se de conceito facilmente apreendido por meio da construção doutrinária, bem como pelas normas regulamentares da CVM. O mesmo se diga quanto ao crime de exercício irregular de cargo, profissão, atividade ou função, cujos conceitos integradores encontram-se na legislação e normativas administrativas relativas ao Sistema Financeiro Nacional.

De qualquer forma, não obstante não se verifique qualquer vício de legalidade quanto aos termos das normas penais em comento, certamente a melhor técnica legislativa recomendaria um maior cuidado na descrição dos conceitos, a fim de deixar os tipos penais o mais fechados possíveis.

Outrossim, por meio de sua função penal de garantia, o tipo "abre as portas" do sistema jurídico penal apenas àquelas condutas que, seja pelo desvalor da ação praticada, seja pelo desvalor do resultado obtido, ofendem, de forma relevante, valores caros à sociedade na qual é aplicada determinada legislação. Assim, dizer que o tipo penal tem que ser bem definido e descrever exatamente a conduta que se quer proteger não é novidade alguma. $\mathrm{O}$ fator novidade na proteção penal dos bens jurídicos difusos a partir da década de 1.990 no Brasil decorre da necessidade de pulverização dos riscos inerentes à sociedade pós-contemporânea, o que se tem dado, via de regra, por meio da criação de tipos penais de perigo abstrato. Busca-se assim englobar não apenas a lesão ao bem jurídico que eventualmente venha a ocorrer, mas também abarcar, de forma sub-reptícia, a mera realização da conduta tipificada penalmente, sem implicações na situação do bem jurídico.

${ }^{355}$ Op. cit., p. 52 
Indubitável que a pulverização dos riscos e perigos é característica da sociedade atual, e como tal deve ser encarada. Contudo, a criminalização de condutas de forma ampla e genérica, dada a imprevisibilidade por parte do legislador, não faz com que os bens jurídicos sejam eficientemente protegidos pelo direito penal. Por outro lado, os crimes de perigo abstrato não podem ser vistos como única solução para a proteção de bens jurídicos supra-individuais. A sua utilização deve ter forma e objetivos claramente delineados.

Apesar de se reconhecer os problemas advindos da utilização de crimes de perigo abstrato, a sua rejeição ampla e irrestrita, caracterizando-os sumariamente por inconstitucionais e em desacordo com os princípios fundamentais do direito penal, também não parece colaborar para uma melhor compreensão quanto à questão da proteção penal dos bens jurídicos supra-individuais.

Todavia, resta claro também que a teoria do bem jurídico não é capaz, per $s i$, de resolver todos os problemas decorrentes da pós-modernidade. Certo está que o delito não pode ser conceituado apenas como uma lesão ao bem jurídico, mas os recentes estudos da teoria do delito, desenvolvendo posicionamentos de meados do século XX, deixam claro que, ao lado do desvalor do resultado, ${ }^{356}$ encontra-se o desvalor da ação como elemento essencial para a caracterização do delito. ${ }^{357}$ Não é o desvalor da ação como aquele caracterizado pela doutrina do totalitarismo jurídico penal, mas desvalor da ação vinculado ao risco produzido pelo autor.

Trata-se, certamente, de tema espinhoso e deveras distante de ser solucionado, cuja investigação científica demandaria o afastamanto dos objetivos da presente dissertação.

\footnotetext{
${ }^{356}$ Sobre o tema: "Há de se ter, em medida de análise, a relevância do resultado que se pretende desvalroar. Inicialmente, diga-se, está a se cuidar, sempre, de situações que denotem um perigo ao bem jurídico protegido. Por segundo, imperiosa se torna a verificação casual quanto a este resultado. Sempre, deverá ser levada em conta a ação ou a omissão incorrente. Assim, como corolário do injusto, pode-se ter que uma conduta, ex ante tida como perigosa, mas que ex post não se mostre agressiva (nem mesmo em termos potenciais) ao bem protegido, não deve ser criminalmente reprovada." (SILVEIRA, Renato de Mello Jorge. Direito Penal Econômico .... Op. cit., p. 80

357 Nesse sentido: FRISCH, Wolfgang; ROBLES PLANAS, Ricardo. Desvalorar e imputar: sobre la imputación objetiva en Derecho Penal. Barcelona: Atelier, 2004.
} 
Cabe aqui, desta forma, verificar se a utilização dos crimes de perigo abstrato - ainda que, consoante aponta Helena Regina Lobo da Costa, seja difícil sua legitimação ${ }^{358}$ - seria adequada à proteção do bem jurídico tutelado pelos crimes contra o Mercado de Capitais.

Alexandre Brandão da Veiga, ao tratar do crime de manipulação de mercado no direito penal português, identifica o tipo penal em questão como crime de perigo abstrato-concreto. Defende o autor sua posição ao referir que o texto legal em momento algum faz referência a relações de causalidade entre os danos e a conduta, mas apenas à idoneidade desta para gerar uma lesão. Acrescenta ainda acerca da dificuldade de comprovação de uma efetiva lesão e aponta a massificação, a fragmentação dos riscos, o anonimato nas transações e a frequência dos fatos como pontos favoráveis à tese. Refere, ademais, à fragmentação das condutas, em que as decisões e atos de execução, via de regra, estão cindidos entre diversos agentes, afirmando, por fim, a dimensão dos perigos que o Mercado de Capitais pode chegar como argumento justificador da posição adotada. $^{359}$

Conclui o autor português, que se trata de crime de perigo abstratoconcreto, pois "é impossível ao legislador definir um elenco fechado de condutas que violam potencialmente o bem (como nos abstractos), mas em que o legislador se tem de bastar pela delimitação das condutas por referência à potencialidade lesiva para certos bens", e afasta a possibilidade do perigo concreto, ao afirmar que o legislador lusitano "se basta com a potencialidade lesiva de certas categorias de atos e não exige que estes tenham gerado um perigo efectivo para o mercado". 360

Ainda no âmbito da doutrina portuguesa, Frederico de Lacerda da Costa Pinto adota postura diversa, ao definir o crime de manipulação de mercado como crime de perigo abstrato em sentido estrito. ${ }^{361}$ Já quanto ao crime de insider trading, adota posição mitigada, dividindo as condutas em três categorias distintas quanto à lesão ao bem jurídico:

\footnotetext{
${ }^{358}$ Op. cit., p. $35-62$

${ }^{359}$ Op. cit., p. 83

${ }^{360}$ Idem, p. 83-84.

361 “[...] quem manipula o mercado controla ilicitamente o regular funcionamento do mercado (assente na transparência e eficiência) e o próprio mecanismo de livre formação das cotações, neutralizando desse modo o risco do seu investimento (ou daqueles em benefício de quem actue) e pondo em risco o investimento dos demais investidores" (Op. cit., p. 97)
} 
São crimes de perigo abstracto os tipos que prevêem como conduta típica a transmissão ilegítima da informação privilegiada; são crimes de perigo abstracto-concreto o aconselhamento e a emissão de ordens de compra, venda ou troca; diversamente, é um crime material (de lesão) o tipo de crime em que ocorre um acto de negociação que se traduza numa efectiva compra, venda ou troca. Neste último caso, a formação do negócio constitui o resultado lesivo do bem jurídico tutelado. ${ }^{362}$

Ana María Prieto Del Pino, por sua vez, ao estudar o crime de uso indevido de informação privilegiada, se posiciona pela validade da proteção do bem jurídico por meio de crimes de perigo abstrato, e justifica sua posição ao afirmar que "o bem jurídico que deve tutelar a proibição das operações de insiders não se vê lesionado por comportamentos consistentes na comunicação a outros sujeitos de dados reservados relevantes", mas sim posto em perigo, "na medida em que se exige que a informação tenha idoneidade - aptidão lesiva - para afetar o preço dos valores mobiliários". 363

Contudo, cabe fazer relevante ressalva quanto aos posicionamentos acima expostos, na medida em que o bem jurídico elegido pelos citados autores é diverso daquele adotado no presente trabalho, dado que pode, eventualmente, levar a conclusões distintas.

Desde logo se pode afirmar que a utilização de crimes de perigo abstrato, admitindo-se, ao menos em tese, a sua legitimidade, não é de todo incompatível com o posicionamento firmado na presente dissertação quanto ao bem jurídico tutelado nos crimes contra o Mercado de Capitais.

Essa, aliás, foi a postura adotada pelo legislador brasileiro, o qual, por meio das formulações típicas da Lei 6.385/76, não vinculou as condutas reputadas ilícitas a um resultado necessário. No tocante ao crime de manipulação de mercado, tampouco exigiu que as condutas fossem potencialmente lesivas. Se assim o fosse, teria se utilizado de

\footnotetext{
${ }^{362}$ Idem, p. 81. Segundo o autor, nos crimes de perigo abstrato-concreto "o perigo é uma característica intrínseca da acção típica". Faria Costa, por sua vez, os define como aqueles "em que a prova da inexistência do perigo determina o não preenchimento do tipo". (COSTA, José Francisco de Faria. O perigo em direito penal. Coimbra: Coimbra Ed., 1992, p. 643). Ângelo Roberto Ilha da Silva, acerca do tema, faz relevante ressalva, ao apontar que as formulações "não parecem muito claras, ao menos ao ponto de convergirem seguramente para um mesmo caminho", motivo pelo qual adota a distinção clássica entre perigo concreto e abstrato. (Op. cit., p. 80)

${ }^{363}$ Op. cit., p. 245, tradução nossa. Em sentido contrário, Luis Ramon Ruiz Rodriguez afirma que a opção do legislador espanhol se deu pela via do perigo concreto, tendo em vista os limites de cunho pecuniário estabelecidos para justificar a intervenção penal do Estado. (Op. cit., p.344-345)
} 
expressões como 'capaz de propiciar vantagem indevida ou prejuízo a terceiros'. Por outro lado, ao tipificar o crime de uso indevido de informação privilegiada, inseriu expressão semelhante ("capaz de propiciar, para si ou para outrem, vantagem indevida, mediante negociação, em nome próprio ou de terceiro"), pelo que se conclui tratar-se de crime de perigo concreto. $^{364}$

Os delitos de perigo diferem dos delitos de lesão, pois para aqueles basta "a existência de uma situação de perigo, basta a lesão potencial. Dividem-se em: delitos de perigo concreto: o perigo integra o tipo como elemento normativo, de modo que o delito só se consuma com a sua real ocorrência para o bem jurídico, isto é, o perigo deve ser efetivamente comprovado, e delito de perigo abstrato." 365

A afirmação de que todas as modalidades de crime de perigo abstrato não exigem a lesão concreta ao bem jurídico, mas, ao contrário, apenas criminalizam meras condutas, não é verdadeira. Quando criminalizadas meras condutas, sem qualquer vínculo com o bem jurídico protegido, seja através do desequilíbrio da relação-base, seja através do grau de risco produzido e/ou assumido pelo agente, caracterizada está a sua inconstitucionalidade. Mas não são todas as modalidades de crime de perigo abstrato que podem ser enquadradas neste grupo.

A análise sobre a constitucionalidade dos delitos de perigo abstrato também deve incluir a ponderação entre o direito constitucional de liberdade do indivíduo e a proporcionalidade da intervenção proposta pelo Estado mediante a tipificação de determinada conduta, além da questão do risco praticado pelo agente.

Assim, ao se estudar os tipos penais que tutelam o Mercado de Capitais, deve-se fazê-lo sob estas duas linhas de argumentação: i) a impossibilidade da criação de tipos penais excessivamente indefinidos; e ii) a necessidade de se assumir uma postura

\footnotetext{
364 "Em suma, os crimes de perigo concreto caracterizam-se pela exigência de constatar-se o perigo caso a caso e, como afirmamos, têm em regra o perigo indicado no tipo. Em certos casos, mesmo que o perigo não esteja indicado no tipo de forma expressa e este seja impreciso, aberto, não poderá configurar crime de perigo abstrato. Ou seja, ausente a taxatividade, dever-se-á, para adequar-se às exigências constitucionais, e para que a legitimidade não reste arranhada, considerar a infração penal como sendo de perigo concreto". (SILVA, Ângelo Roberto Ilha da. Op. cit., p. 71)

365 PRADO, Luiz Regis. Curso de direito penal brasileiro. Vol 1. 4. ed. São Paulo: Revista dos Tribunais. 2004. p.241.
} 
diferenciada no que tange à aceitação dos crimes de perigo abstrato, não os rejeitando liminarmente, mas buscando critérios para sua aplicação na proteção dos delitos coletivos.

Consoante exposto em apartado anterior, o bem jurídico adotado para fins do presente trabalho consiste na proteção aos interesses patrimoniais do público investidor. Dessa maneira, consegue-se chegar de forma segura a um necessário referencial antropocêntrico exigido pela teoria pessoal do bem jurídico.

Nesse diapasão, a conduta proibida deverá acarretar perigo ao bem jurídico coletivo, mas também deve criar risco aos bens individuais que o lastreiam, caso contrário, consoante afirma Pierpaolo Cruz Bottini, "não serão atividades relevantes sob o ponto de vista penal". 366

Por outro lado, há que se ter em mente que ao adotar formulações de perigo abstrato, o legislador nada mais faz do que presumir que a simples existência do risco, per $s i$, configura uma ameaça ao bem jurídico. Trata-se, consoante observado por Helena Regina Lobo da Costa, de uma valoração jurídica. ${ }^{367}$ Assim sendo, uma solução possível seria admiti-la como uma presunção iuris tantum, aceitando-se a prova da não colocação do bem em perigo. ${ }^{368}$

Ademais, há que se ultimar um juízo quanto à lesividade das condutas incriminadas. Não se trata aqui, somente da efetiva exposição do bem jurídico a lesão ou

\footnotetext{
${ }^{366}$ Op. cit., p. 192

${ }^{367}$ Op. cit., p. 36

${ }^{368}$ Nesse sentido, vale transcrever interessante posicionamento de Juarez Tavares: "Com relação aos delitos de perigo abstrato, por sua parte, uma estruturação democrática do injusto impõe que a presunção legal de perigosidade da conduta possa ser submetida a uma prova empírica de refutação. Isto não implica que esses delitos devam ser interpretados como se fossem delitos de perigo concreto. Aqui não se está pressupondo a existência concreta do perigo para a consumação do delito. O que se exige, em um direito penal realista, é que ao imputado se lhe abra sempre a possibilidade de demonstrar que o perigo pressuposto na lei não se poderia verificar no caso concreto, em face da inofensividade de sua conduta. Para que se torne possível essa refutação, que decorre inexoravelmente dos princípios da ampla defesa e da presunção de inocência, a função do direito penal não pode estar direcionada à proteção do bem jurídico. A legitimidade da incriminação está condicionada, em qualquer caso, ao pressuposto de que o bem jurídico que constitui o fundamento da norma tenha sido lesado ou posto em perigo, o que só se perfaz com a demonstração empírica de que a própria ação proibida era idônea a produzir essa lesão ou aquele perigo.” (Op. cit., p. 226). Em sentido contrário, quanto ao ônus da prova da colocação do bem jurídico em perigo, a posição de Pierpaolo Cruz Bottini: "Faz-se necessária a constatação da periculosidade da atividade em relação aos bens protegidos, sob uma perspectiva ex ante, que leve em conta os conhecimentos especiais do autor e os conhecimentos científicos disponíveis sobre os cursos causais decorrentes do comportamento. A demonstração do risco ex ante será sempre tarefa da acusação, diante da regra constitucional da presunção de inocência, e a ausência deste potencial de perigo implica a irrelevância do ato sob a perspectiva penal". (Op. cit., p. 297)
} 
perigo, mas sim, como afirma Pierpaolo Cruz Bottini, da "desestabilização de expectativas diante de atividades arriscadas, com mero potencial de perigo", 369

Acerca do tema, importante citar o posicionamento de Faria Costa, ao apontar três níveis diversos de lesividade; um primeiro, consistente no dano, propriamente dito, ao bem jurídico; o segundo, consubstanciado na colocação do bem em perigo concreto; e um terceiro, nos quais se encontram os crime de perigo abstrato, compreendido por um 'cuidado de perigo', necessariamente vinculado à proteção de um bem jurídico com dignidade penal. ${ }^{370}$

Nessa esteira de entendimento, propõe o autor português uma necessária descrição minuciosa do legislador quanto à conduta ou condutas proibidas ${ }^{371}$, cabendo ainda ao intérprete, perante o caso concreto, "apelando à hermeneia, repensar o tipo perscrutando o seu interior, no sentido de o avaliar em função do princípio da ofensividade". 372

Diante do exposto, ainda que não se pretenda no presente trabalho defender a incriminação das condutas ofensivas ao Mercado de Capitais exclusivamente por meio de crimes de perigo abstrato, não parece de todo despropositada sua adoção, desde que conferidos critérios materiais capazes de delimitar sua utilização. ${ }^{373}$

\footnotetext{
${ }^{369}$ Op. cit., p. 205

370 O perigo em direito penal. Op. cit., p. 642 e ss.

371 'Dir-se-ia que o 'aparente' défice de legitimidade é contrabalançado pela extraordinária minúcia que o legislador põe, deve pôr, na descrição das condutas proibidas. Assim, se o tipo legal de crime de perigo abstracto é composto por tais elementos, não vemos em que é que sua legitimidade possa ser tocada." (Idem, p. 645-646)

${ }^{372}$ Ibidem. No mesmo sentido: "Esta verificação do potencial lesivo do comportamento se faz por um juízo de periculosidade da ação descrita no tipo como de perigo abstrato. Apenas a conduta que ostente periculosidade tem o condão de movimentar o direito penal de forma legítima. As ações e omissões que não impliquem riscos, ao menos potenciais, de afetação do bem jurídico, não podem interessar ao sistema repressor. Aqui reside o princípio da lesividade e sua força interpretativa. Sua compreensão exige definir a periculosidade como elemento nuclear da ação penalmente relevante. A construção do tipo penal, seja de perigo abstrato, seja de lesão, demanda um injusto material, que será o risco de dano ao bem protegido, mesmo que sob uma perspectiva ex ante ou abstrata, de modo que a ausência deste risco afastará a lesividade e a incidência da norma penal não será adequada aos preceitos de um direito penal racional e funcional". (BOTTINI, Pierpaolo Cruz. Op. cit., p. 205-206)

${ }^{373}$ Vale trazer à baila reflexão proposta por Miguel Reale Júnior: “[...] o desafio do Direito Penal hodierno está em limitar as figuras de perigo abstrato, que beiram a inconstitucionalidade por ausência de lesividade, sendo compreensível que a impossibilidade inafastável de descer à discriminação taxativa de todas as situações de perigo e a impossibilidade de prova de perigo, conduza à criação de figuras de perigo abstrato ou presumido". (Instituições de Direito Penal. Vol. 1. Rio de Janeiro: Forense, 2002, p. 279)
} 
Assim, a partir desta breve análise, fica evidente que a resposta sobre legitimação dos crimes de perigo abstrato passa necessariamente pela diferenciação de seu estudo, e não pela inclusão de todos os tipos de perigo abstrato em uma mesma categoria. ${ }^{374}$ Não se pretende, evidentemente, esgotar a questão; mas sim demonstrar que podem existir meios para justificar a incriminação das condutas lesivas ao Mercado de Capitais por meio de crimes de perigo abstrato, dentre as quais as alternativas expostas no presente apartado, aptas a contribuir para a construção de um salutar debate.

\subsection{Do aperfeiçoamento da tutela penal}

Dentre os fins pretendidos pela presente dissertação, cumpre a apresentação de uma proposta, ainda que embrionária, de aperfeiçoamento da tutela penal do Mercado de Capitais no Brasil. Nesse diapasão, se objetivará a formulação de uma nova redação aos tipos penais dos crimes de manipulação de mercado e uso indevido de informação privilegiada. Como critérios norteadores, serão considerados, além dos interesses patrimoniais dos investidores como bem juridicamente protegido, uma especial preocupação em formular tipos o mais fechado possíveis.

Quanto ao crime de manipulação de mercado, verifica-se, de plano, a inexistência de qualquer referência ao potencial lesivo da conduta, ao contrário do que ocorre com o tipo penal do uso indevido de informação privilegiada. O legislador limitouse a exigir do agente, na hipótese do art. 27-C, o fim de obter vantagem indevida ou causar prejuízos a terceiros.

Dessa forma, parece adequado propor que as condutas incriminadas tenham a capacidade de propiciar vantagem indevida ou prejuízo a terceiros.

Quanto ao dolo específico do agente, seria também adequada a substituição do termo "alterar artificialmente o regular funcionamento do mercado", na medida em que resulta em expressão demasiado indefinida, por "alterar artificialmente o valor da cotação de valores mobiliários". Propõe-se, com isso, uma maior taxatividade ao tipo penal, o que, sem sombra de dúvida garante maior segurança jurídica. Ademais, tal formulação parece,

${ }^{374}$ Nesse sentido: GRECO, Luís. Op. cit., p. 89-147. 
também mais apropriada a uma exigência de lesividade, mínima que seja, e não representa qualquer alteração quanto ao dolo específico exigido.

Portanto, uma possível nova redação do tipo penal do artigo 27-C poderia

ser:

Realizar operação simulada ou outra manobra fraudulenta, com a finalidade de alterar artificialmente o valor da cotação de valores mobiliários negociados em bolsas de valores, de mercadorias e futuros, no mercado de balcão ou no mercado de balcão organizado, capaz de propiciar vantagem indevida para si ou para outrem, ou provocar prejuízos a terceiros.

Já no que concerne ao crime de uso de informação privilegiada, poder-se-ia dar um tratamento mais delimitado à definição de informação privilegiada, agregando ao tipo penal as características necessárias para que uma informação seja efetivamente considerada como privilegiada.

Importante, ademais, ressalvar que a opção do legislador brasileiro pela necessária quebra de um dever de sigilo nos casos de insider trading, dá margem a uma relevante discussão quanto à utilização da informação privilegiada por pessoa desobrigada de tal dever, e que teve acesso à mesma por meios outros, ainda que lícitos. Parece aqui, que talvez a melhor solução, considerando-se o bem jurídico tutelado, seria tornar o crime de uso indevido de informação privilegiada um crime comum, podendo qualquer pessoa que dolosamente se utilize da informação privilegiada figurar como sujeito ativo.

Nessa esteira de entendimento, uma proposta para nova redação do tipo penal do artigo 27-D ficaria assim configurada:

Utilizar informação privilegiada, capaz de propiciar, para si ou para outrem, vantagem indevida ou prejuízo a terceiros, mediante negociação, em nome próprio ou de terceiro, com valores mobiliários em bolsas de valores, de mercadorias e futuros, no mercado de balcão ou no mercado de balcão organizado.

Parágrafo único - considera-se informação privilegiada toda informação sigilosa, relacionada a companhia emissora de valores mobiliários, que diga respeito a fatos ou dados concretos, e que seja idônea a alterar o valor da cotação de valores mobiliários. 
No tocante às penas privativas de liberdade cominadas, tendo em vista a evidente falta de proporcionalidade à sanção penal aplicável ao crime de manipulação de mercado, sugere-se que seja reduzida a pena máxima aplicável ao crime do artigo 27-C para o patamar de cinco anos de reclusão. Outrossim, caso se parta do pressuposto de que a manipulação configuraria crime mais grave, poder-se-ia exacerbar a pena mínima para dois anos de reclusão, mantendo-se, todavia, o patamar da pena máxima em cinco anos de reclusão.

Diante do exposto, unindo-se contornos mais adequados, precisos e com definições mais afinadas com um direito menos aberto; bem como, utilizando-se de instrumental hermenêutico mais acurado, e menos positivista, talvez se encontre uma fórmula de tutela mais próxima do ideal. De todo modo, tal tarefa demanda uma reflexão mais aprofundada, não comportada na presente dissertação, inclusive no tocante à adoção de soluções implementadas pelas legislações estrangeiras, como a utilização de um valor, ou outro referencial concreto que configure um limite entre a intervenção administrativa e a penal. Ademais, é necessária uma ponderação crítica quanto a uma aparente acessoriedade administrativa, sendo certo que a grande dificuldade reside na identificação dos casos mais graves, posto que somente nestes poderá atuar o direito penal. 


\section{CONCLUSÃO}

1. O advento de novos riscos, decorrentes da sociedade pós-moderna, eminentemente marcada pelo desenvolvimento tecnológico desenfreado e pela livre circulação de capitais, coloca em xeque as estruturas do direito penal clássico.

2. Como decorrência de um contexto globalizado, deu-se um incremento do direito penal econômico, manifestado pela excessiva criminalização de condutas relacionadas à atividade empresarial; citando-se, como exemplos, a tutela penal do meio ambiente, das relações de consumo, da concorrência e da esfera tributária.

3. O Mercado de Capitais assume relevante papel dentro de uma economia globalizada, tratando-se de importante instrumento de tomada de financiamento pelas companhias por meio da mobilização de poupança dos investidores. Nesse contexto, a internacionalização do Mercado de Capitais traz uma série de benefícios; mas, por outro lado, resulta em ambiente propício à prática de ilícitos, implicando em riscos que não podem ser ignorados pelo direito penal.

4. Dessa forma, a busca por uma maior segurança nos Mercados de Capitais tem refletido na edição de uma série de normas e regulações em todo o mundo, com especial destaque a um incremento dos mecanismos repressivos, tanto nos Estados Unidos da América, como na União Européia; onde se verifica uma relevante preocupação em harmonizar os sistemas legais reguladores do Mercado de Capitais. No Brasil a criminalização de condutas ofensivas ao Mercado de Capitais se deu em 2.001, com a edição da Lei 10.303/2001, que inseriu na Lei do Mercado de Capitais novos tipos penais.

5. Ocorre que, no mais das vezes, a criminalização de tais condutas reflete uma utilização simbólica do direito penal, orientada a ações típicas das classes mais favorecidas e voltada a aplacar os anseios da opinião pública. Ademais, verifica-se uma inadequada internacionalização do direito penal, com a importação de modelos legislativos estrangeiros; e mesmo a imposição de Leis penais que extrapolam os limites territoriais nacionais, como no caso da Sarbanes-Oxley Act. Contudo, essa tentativa de conferir maior rigor à repressão de ilícitos por meio do direito penal, mas desprovida de qualquer base 
científico-dogmática, a médio e longo prazo traz como consequência um efeito reverso, mostrando-se uma forma ineficaz e que resulta no aumento da sensação geral de impunidade e insegurança.

6. Para uma correta verificação da tutela penal do Mercado de Capitais fazse necessário o exame dos institutos do direito do Mercado de Capitais, do direito societário, e do direito administrativo. Dessa forma, verifica-se que o direito do Mercado de Capitais está orientado para a tutela do correto e eficiente funcionamento do mercado; com especial ênfase na garantia de transparência das informações - fundamentais para a justa cotização dos valores mobiliários. Nesse contexto, a proteção dos investidores assume papel subsidiário dentro de uma regulação do Mercado de Capitais em sentido amplo.

7. Quanto à análise acerca da tutela penal do Mercado de Capitais, esta deverá passar, necessariamente, pela identificação do bem jurídico protegido. Além disso, é imprescindível a adoção de critérios externos ao bem jurídico, consistentes em uma averiguação quanto à necessidade, idoneidade e aptidão da intervenção penal.

8. Atualmente há grande discussão dogmática quanto à relevância da Teoria do bem jurídico. Todavia, ainda que não se possa estabelecer uma verdade absoluta quanto a este instituto, não se pode dele prescindir como referente material limitador da intervenção penal do Estado.

9. A doutrina estrangeira tem enfrentado a questão do bem jurídico nos crimes contra o Mercado de Capitais, estando, todavia, se encontra definitivamente distante de uma posição unânime.

10. Partindo-se da Teoria pessoal do bem jurídico desenvolvida por Hassemer, identificou-se como bem jurídico nos crimes contra o Mercado de Capitais os interesses patrimoniais do público investidor - compreendido como os investidores efetivos e futuros -, como sendo a proposta mais adequada quanto à necessidade de vinculação a um referente antropocêntrico. Não se trata, todavia, de um bem jurídico individual; mas sim supra-individual, que guarda uma relação - ainda que mediata - com bens de natureza individualizada. 
Dessa forma, tendo em vista que a proteção dos interesses patrimoniais dos investidores assume uma posição secundária na regulação lato sensu do Mercado de Capitais, a sua eleição, como bem juridicamente tutelado na esfera penal, atende ao princípio da subsidiariedade. Ademais, a tutela penal de tais interesses parece também dotada da devida relevância ante a danosidade social decorrente de sua afetação; ficando atendidos, pois, os critérios de fragmentariedade e necessidade.

11. Quanto aos tipos em espécie - manipulação de mercado e uso indevido de informação privilegiada -, foram analisados aqueles relativos às operações do Mercado de Capitais propriamente ditas. Procurou-se, nesse diapasão, conferir limites a uma estrutura típica excessivamente aberta; mas que não está totalmente desvinculada de uma integração interpretativa por meio de conceitos externos ao direito penal.

12. Por fim, no tocante à utilização dos crimes de perigo abstrato como formulação mais adequada para os crimes contra o Mercado de Capitais, apesar da necessidade de uma investigação mais aprofundada, não parece de todo despropositada, desde que observados certos critérios e limites materiais. 


\section{BIBLIOGRAFIA}

ANDRADE, Manuel da Costa. "A dignidade penal e a carência de tutela penal" in Revista portuguesa de ciência criminal. Ano 2, t. 2, Coimbra: Aequitas, abr./jun. 1.992, p. 173-205.

ANDREZO, Andrea Fernandes. "The Sarbanes-oxley act and the rules applicable to foreign companies: the possible impacts on the capital markets" in Revista de Direito Mercantil, Industrial, Econômico e Financeiro. São Paulo. v.42. n.132. p.25-54. out./dez. 2.003.

ANTONELI, Osvaldo Gianotti. Inadequação e ineficácia da tutela penal tributária no ordenamento jurídico brasileiro. Dissertação de mestrado apresentada à Faculdade de Direito da Universidade de São Paulo em 2.008.

ASSAF NETO, Alexandre. Mercado Financeiro. $6^{\text {a }}$ ed. São Paulo: Atlas, 2.005.

BAJO FERnANDÉZ, Miguel. Compendio de Derecho Penal, Parte Especial. Vol II. Madrid: Centro de Estudios Ramon Areces, 1.998.

BECK, Ulrich. La sociedade del riesgo: hacia una nueva modernidad. Trad. Jorge Navarro, Daniel Jiménez e Maria Rosa Borras. Barcelona: Paidos, 1998. . ¿Que és la globalización? Trad. Jorge Navarro, Daniel Jiménez e Maria Rosa Borras. Barcelona: Paidos, 1.998.

BIANCHINI, Alice. "Direito penal econômico: os fins justificam os meios?" in Boletim IBCCrim, São Paulo, Vol. 7, nº 84, p. 9-10, nov. 1.999.

BINDING, Karl. Compendio di diritto penale: parte generale. Trad. Adelmo Borettini. Roma: Athenaem, MCMXXVII.

BIRKE, David F. "The toothless watchdog: corporate fraud and the independent audit: how can the public's confidence be restored?" in University of Miami Law Review. Miami. v.58. n.3. p.891-922. abr. 2.004.

BORBA, José Edwaldo Tavares. Direito Societário. $8^{\mathrm{a}}$ ed. Rio de Janeiro: Renovar, 2.003.

BORGERTH, Vania Maria da Costa. SOX: entendendo a Lei Sarbanes-oxley - um caminho para a informação transparente. São Paulo: Thomson Learning, 2.007.

BOTTINI, Pierpaolo Cruz. Crimes de perigo abstrato e princípio da precaução na sociedade de risco. São Paulo: Revista dos Tribunais, 2.007.

BUGALlO ALVAREZ, Alejandro. "A Comissão de Valores Mobiliários, instância reguladora independente?" in Direito, Estado e Sociedade. Rio de Janeiro. n.3. p.132. ago./dez. 1.993. 
BUSTOS RAMÍREZ, Juan. Manual de derecho penal español. Barcelona: Ariel, 1984. . "Necesidad de la pena, función simbólica y bien jurídico medio ambiente" in Pena y Estado. Santiago de Chile: Jurídica ConoSur, 1.995.

CALDERÓN SUSÍN, Eduardo. "El abuso de información privilegiada en el mercado de valores" in Cuadernos de Derecho Judicial, 1.996, p. 230.

CANOTILHO, J. J. Gomes. Direito Constitucional. Coimbra: Almedina, 1.993.

CANTIDIANO, Luiz Leonardo. "Mercado de valores mobiliários" in Revista Brasileira de Mercado de Capitais. Rio de Janeiro. v.13. n.38. p.59-61. jan./mar. 1.987.

CARRASCO, Omar Morales. "El mercado de valores mobiliarios en los Estados Unidos de América" in Revista de Derecho. Facultad de Ciencias Jurídicas y Sociales. Universidad de Concepción. Concepción. v.48. n.207. p.105-20. ene./jun. 2.000.

CARVAlHOSA, Modesto e EIZIRIK, Nelson. A nova Lei das S/A. São Paulo: Saraiva, 2.002 .

CAVALCANTE, Francisco e MISUMI, Jorge Yoshio. Mercado de capitais, o que é, como funciona. $6^{\mathrm{a}}$ ed. Rio de Janeiro: Campus, 2.005.

CERNICHIARO, Luiz Vicente e Costa JúNIOR, Paulo José da. Direito Penal na Constituição. $3^{\mathrm{a}}$ ed. São Paulo: Revista dos Tribunais, 1.995.

COMPARATO, Fábio Konder. "Natureza Jurídica das Bolsas de Valores e delimitação do seu objeto" in Direito Empresarial: estudos e pareceres. São Paulo: Saraiva, 1.995, p. 319-330.

. "A regra do sigilo nas ofertas públicas de aquisição de ações" in Direito Empresarial: estudos e pareceres. São Paulo: Saraiva, 1.995, p. 331-353.

COSTA, Helena Regina Lobo da. Proteção ambiental, direto penal e direito administrativo. Tese de doutoramento apresentada à Faculdade de Direito da Universidade de São Paulo em 2.007.

COSTA, Helena Regina Lobo da; ALONSO, Leonardo; COELHO, Marina Pinhão. "Dos Crimes contra o mercado de capitais" in Revista Literária de Direito. Ano X, n. 53, p. 30-33, ago-set/2.004.

COSTA, José Francisco de Faria. O perigo em direito penal. Coimbra: Coimbra Editora, 1.992.

COSTA, José Francisco de Faria e RAMOS, Maria Elisabete. O crime de abuso de informação privilegiada (insider trading) - a informação enquanto problema jurídico-penal. Coimbra: Coimbra Editora, 2.006.

COSTA JR., Paulo José da; QUEIJO, Maria Elizabeth; MACHADO, Charles M. Crimes do colarinho branco. $2^{\mathrm{a}}$ ed. São Paulo: Saraiva, 2.002. 
COSTA, Roberto Teixeira da. Mercado de capitais: uma trajetória de 50 anos. São Paulo: Imprensa Oficial do Estado de São Paulo, 2.006.

COSTA PINTO, Frederico de Lacerda da. O novo regime dos crimes e contra-ordenações no Código dos Valores Mobiliários. Coimbra: Almedina, 2.000.

CUEVA, Ricardo Villas Bôas. "Termo de compromisso no processo administrativo sancionador do Banco Central: possibilidades e limites." in Direito administrativo sancionador: sistema financeiro nacional. Coord. Fábio Medina Osório. Belo Horizonte: Fórum, 2.007, p. 281-309.

CUNHA, Maria da Conceição Ferreira da. Constituição e crime: uma perspectiva da criminalizção e da descriminalização. Porto: Universidade Católica Portuguesa, 1.995.

DE SANCTIS, Fausto Martins. Punibilidade no Sistema Financeiro Nacional. Campinas: Millenium, 2.003.

DIAS, Augusto Silva. Globalização, "Sociedade de Risco" e o futuro do Direito Penal. Coimbra: Almedina, 2.001.

DIAS, Jorge de Figueiredo. Questões fundamentais de direito penal revisitadas. São Paulo: Revista dos Tribunais, 1.999.

DÍEZ RIPOLLÉS, José Luis. "El derecho penal simbólico y los efectos de la pena” in Actualidad Penal, Madrid, fasc. 1, jan. 2.001.

DUBEUX, Júlio Ramalho. A comissão de valores mobiliários e os principais instrumentos regulatórios do mercado de capitais brasileiro. Porto Alegre: Sérgio Antonio Fabris Editor, 2.006.

EIZIRIK, Nelson. Reforma das S.A. \& do Mercado de Capitais. $2^{\mathrm{a}}$ ed. Rio de Janeiro: Renovar, 1.998. . Instituições financeiras e mercado de capitais. Rio de Janeiro: Renovar, 1.998. . "A urgente reforma da Lei 6.385/76" in Revista de Direito Mercantil, Industrial, Econômico e Financeiro. São Paulo. v.34. n.98. p.58-62. abr./jun. 1.995. . "Regime Jurídico do mercado de capitais - Modificações introduzidas pela lei 9.457/9" in Revista do Advogado. São Paulo. n.52. p.32-8. fev. 1.998. . O papel do Estado na regulação do mercado de capitais. Rio de Janeiro: IBMEC, 1.977.

EIZIRIK, Nelson e PARENTE, Flávia. "Ampliação do conceito de valor mobiliário no Direito Brasileiro" in Revista da CVM, n 27, 1.998.

ENTRENA RUIZ, Daniel. El empleo de información privilegiada en el mercado de valores: un estudio de su régimen administrativo sancionador. Navarra: Editorial Arazandi, 2.006. 
ESTELLITA, Heloisa. Integração regional e direito penal. Tese de doutorado apresentada à Faculdade de Direito da Universidade de São Paulo em 2.004. . A tutela penal e as obrigações tributárias na Constituição Federal.São Paulo: Revista dos Tribunais, 2.001.

FARALDO CABANA, Patrícia. "Algunos aspectos de uso de información privilegiada en el mercado de valores y el proyecto de código penal de 1.994" in Estudios penales y criminologicos. XVIII. Santiago de Compostela: Servicio de Publicaciones e intercambios de la Universidade de Santiado de Compostela, 1.995.

FARIA, Eduardo José. "O judiciário após a globalização” in Revista Brasileira de Ciências Criminais.Ano 4, n. 26, São Paulo: Revista dos Tribunais.

FEIJÓO SÁNCHEZ, Bernardo. Derecho penal de la empresa y imputación objetiva. Madrid: Editorial Reus, 2.007.

FEINBERG, Joel. The moral limits of the criminal law. Harm to others. New York: Oxford University Press, 1.986, vol. 1.

FELDENS, Luciano. Direitos fundamentais e direito penal: garantismo, deveres de proteção, princípio da proporcionalidade, jurisprudência constitucional penal, jurisprudência dos tribunais de direitos humanos. Porto Alegre: Livraria do Advogado, 2.008.

FERNANDES, Paulo Silva. Globalização, 'sociedade de risco' e o futuro do direito penal - panorâmica de alguns problemas comuns. Coimbra: Almedina, 2.001

FIANDACA, Giovanni. "Il 'bene giuridico' come problema teorico e come criterio di politica criminale" in Rivista Italiana di Diritto e Procedura Penale, 1.982.

FIGUEROA BUSTAMANTE, Hernán. "Sistema financiero y mercado de valores: balance y propuestas" in Revista de Derecho y Ciencias Políticas. Lima. v.58. n.1/2. p.23948. 2.001 .

FORTUNA, Eduardo. Mercado Financeiro. $16^{\mathrm{a}}$ ed. Rio de Janeiro: Qualitymark, 2.005.

GRACIA MARTÍN, Luis. Prolegômenos para a luta pela modernização e expansão do Direito Penal e para a crítica do discurso de resistência. Trad. Érica Mendes de Carvalho. Porto Alegre: Sérgio Antonio Fabris Ed., 2.005.

GOMES. Mariângela Gama de Magalhães. O princípio da proporcionalidade no direito penal. São Paulo: Revista dos Tribunais, 2.003.

GOMES FILHO, Antonio Magalhães. A motivação das decisões penais. São Paulo: Revista dos Tribunais, 2.001.

GÓMEZ INIESTA, Diego J. La utilización abusiva de información privilegiada en el mercado de valores. Barcelona: Mc Graw Hill, 1.997. 
GRAU, Eros Roberto. A ordem econômica na constituição de 1988. $9^{\mathrm{a}}$ ed. São Paulo: Malheiros, 2.004.

GRINOVER, Ada Pellegrini. "A problemática dos interesses difusos" in A tutela dos interesses difusos. São Paulo: Max Limonad, 1.984.

GRECO, Luís. "'Princípio da ofensividade' e crime de perigo abstrato - Uma introdução ao debate sobre o bem jurídico e as estruturas do delito" in Revista Brasileira de Ciências Criminais, n. 49, p. 89-147, jul.-ago de 2.004.

GUIMARÃES, Cláudio Alberto Gabriel. "O impacto da globalização sobre o direito penal” in Ciências Penais. ano 1, n. 1, jul-dez/2.004, p. 246-256. São Paulo: Revista dos Tribunais, 2.004.

GULLO, Roberto Santiago Ferreira. Direito Penal Econômico. Rio de Janeiro: Lumen Juris, 2.001 .

HASSEMER, Winfried. "Lineamentos de una teoria personal del bien jurídico" in Doctrina Penal. Trad. Patrícia S. Ziffer. Buenos Aires, n. 12, abr-set. 1.989, p. 275285.

. "História das idéias penais na Alemanha do Pós-Guerra" in Revista Brasileira de Ciências Criminais, São Paulo, v. 2, n. 6, p. 36-69, abr.jun. 1.994.

. "Derecho Penal Simbólico y Protección de Bienes Jurídicos" In Pena y Estado: función simbólica de la pena. n. 1, Barcelona: PPU, 1.991.

. "Perspectivas del derecho penal futuro" in Revista Penal. n. 1. Barcelona: 1.998 , p. $37-41$

HAZEN, Thomas Lee. Principles of securities regulation. $2^{\mathrm{a}} \mathrm{ed}$. St. Paul: Thomson/West, 2.005 .

HEFENDEHL, Roland. "De largo aliento: el concepto de bien jurídico" Trad. Gonzalo Medina Schulz. in HEFENDEHL, Roland (ed.). La teoria del bien jurídico. Madrid: Marcial Pons, 2.007.

. "El bien jurídico como eje material de la norma penal" Trad. María Martín Lorenzo. in HEFENDEHL, Roland (ed.). La teoria del bien jurídico. Madrid: Marcial Pons, 2.007.

- “Debe ocuparse el Derecho penal de riesgos futuros? Bienes jurídicos colectivos y delitos de peligro abstracto" in Revista Electrónica de Ciencia Penal y Criminologia. Disponível em: http://criminet.ugr.es/recpc/recpc_04-14.pdf.

HERNÁNDEZ SAINZ, Esther. El abuso de información privilegiada en los mercados de valores. Pamplona: Thomson, 2.007.

HIRSCH, Andrew von. "El concepto de bien jurídico y el 'principio del daño"”. Trad. Gonzalo Medina Schulz. in HEFENDEHL, Roland (ed.). La teoria del bien jurídico. Madrid: Marcial Pons, 2.007.

HORMAZÁBAL MALARÉE, Hernán. Bien jurídico y estado social y democrático de derecho: el objecto protegido por la norma penal. Barcelona: PPU, 1.991. 
JAKOBS, Günther. Derecho Penal - parte general, fundamientos de la imputación.. $2^{\mathrm{a}}$ ed. Madrid: Marcial Pons, 1.997.

. ¿Qué protege el derecho penal: bienes jurídicos o la vigencia de la norma?” in JAKOBS, Günther e CANCIO MELIÁ, Manuel. El sistema funcionalista del derecho penal. Lima: Grijley: Universidad de Piura, 2.000, p. 42-60.

KANDIR, Antonio. "A reforma da lei das S.A. e o desenvolvimento" in Revista de Direito Bancário, do Mercado de Capitais e da Arbitragem. São Paulo. v.4. n.12. p.13-9. abr./jun. 2.001.

KRUGMAN, Paul R. e OBSTFELD, Maurice. Economia Internacional: teoria e política. Trad. Eliezer Martins Diniz. São Paulo: Pearson Addison Wesley, 2.005.

KÜMPEL, Siegfried. Direito do Mercado de Capitais - do ponto de vista do direito europeu, alemão e brasileiro. Rio de Janeiro: Renovar: 2.007.

LEÃES, Luiz Gastão Paes de Barros. Mercado de Capitais e “insider trading”. São Paulo: Revista dos Tribunais, 1.982.

LENGRUBER, Eduardo Faço; COSTA JR, Newton C. Affonso da; LEAL, Ricardo Pereira Câmara. Mercado de Capitais: análise empírica no Brasil. São Paulo: Atlas, 2.000.

LUISI, Luiz. Os princípios constitucionais penais. Porto Alegre: Sergio Antonio Fabris Editor, 1.991.

MACHADO, Maíra Rocha. Internacionalização do direito penal: a gestão de problemas internacionais por meio do crime e da pena. São Paulo: Editora 34, 2.004.

MACHADO, Marta Rodriguez de Assis. Sociedade do Risco e Direito Penal: uma avaliação de novas tendências político-criminais. São Paulo: IBCCRIM, 2.005.

MACHADO, Manuel Pedrosa. "A entrada em vigor das incriminações de abuso de informação e de manipulação do mercado do Código do Mercado de Valores Mobiliários: chamada de atenção para mais um erro de técnica legislativa" in Direito Penal Econômico e Europeus: textos doutrinários - problemas especiais. Vol. 2. Coimbra: Coimbra Ed., 1.999, p. 287-300.

"Sobre a tutela penal da informação nas sociedades anônimas: problemas da reforma legislativa" in Direito Penal Econômico e Europeus: textos doutrinários problemas especiais. Vol. 2. Coimbra: Coimbra Ed., 1.999, p. 173-226.

MARTÍNEZ-BUJÁN PÉREZ, Carlos. Derecho Penal Económico - Parte General. Valencia: Tirant lo Blanch, 1.998. . Derecho Penal Económico - Parte Especial. Valencia: Tirant lo Blanch, 1.999.

MELLO, Pedro Carvalho. "Uma avaliação da regulação do mercado de capitais segundo a ótica de custos e benefícios" in Revista da CVM. Rio de Janeiro. n.32. p.24-32. set. 2.000 .

"Desenvolvimento financeiro e do mercado de capitais: uma resenha dos estudos recentes" in Revista da CVM. Rio de Janeiro. n.30. p.74-84. dez. 1.999. 
MENDOZA BUERGO, Blanca. El derecho penal en la sociedad de riesgo. Madrid: Civitas, 2.001.

MIRANDA, Jorge. Manual de Direito Constitucional. 2a ed. Coimbra: Coimbra Ed., 1.998. t. IV.

MOCCIA, Sergio. "Dalla tutela di beni allá tutela di funzioni: tra illusioni postmoderne e riflussi illiberali" in Rivista Italiana di Diritto e Procedura Penale. Fasc. 2, 1.995.

MONROY ANTÓN, Antonio J. El delito de abuso de informacién privilegiada en el mercado de valores. Madrid: Dijusa, 2.006.

MOSQUERA, Roberto Quiroga. "Os princípios informadores do Direito do Mercado Financeiro e de Capitais" in Aspectos atuais do Direito do Mercado Financeiro e de Capitais. Coord. Roberto Quiroga Mosquera. São Paulo: Dialética, 1.999, p. 257271.

MUÑOZ CONDE, Francisco. Direito Penal e controle social. Rio de Janeiro: Forense, 2.005 .

NERVI, Andrea. "La nozione giuridica di informazione e la disciplina di mercato; argomenti di discussione" in Rivista del Diritto Commerciale e del Diritto Generale delle Obbligazioni. Padova. v.96. n.9-10/11-12. p.843-72. sett./dic. 1.998.

NEUMANN, Ulfrid. "Princípio da proporcionalidade" in Revista Brasileira de Ciências Criminais. n. 71. São Paulo: Revista dos Tribunais, março-abril de 2.008, p. 207-229.

NUSDEO, Fábio. Curso de economia: introdução ao direito econômico. $3^{\mathrm{a}}$ ed. rev. e atual. São Paulo: Revista dos Tribunais, 2.001.

OLIVEIRA, Márcia Souza e Silva de. "Dos crimes contra o mercado de capitais" in Revista AJUFE. nº 21. p. 409-423. Brasília, 2.004.

OSÓRIO, Fábio Medina. "Devido processo administrativo sancionador no Sistema Financeiro Nacional" in Direito administrativo sancionador: Sistema Financeiro Nacional. Coord. Fábio Medina Osório. Belo Horizonte: Fórum, 2.007, p. 13-39.

PASCHOAL, Janaina Conceição. Constituição, Criminalização e Direito Penal Mínimo. São Paulo: Revista dos Tribunais, 2.003.

PAULA, Áureo Natal de. Crimes contra o Sistema Financeiro Nacional e o mercado de capitais. Curitiba: Juruá, 2.006.

PEDROSO, Paula e VERDELHO, Pedro. "Crimes de mercado de valores mobiliários" in Revista do Ministério Público. Vol. 19. fasc. 75. jul-set/1.998, p. 115-138.

PENNA, Estella de Araújo. "Desenvolvimento econômico e mercado de capitais: a nova lei das S.A." in Revista de Direito Bancário, do Mercado de Capitais e da Arbitragem. São Paulo. v.4. n.11. p.267-8. jan./mar. 2.001. 
PESSOA, Ana Paula Gordilho. "As constantes mudanças legislativas no mercado de capitais e seus efeitos" in Revista de Direito Mercantil, Industrial, Econômico e Financeiro. São Paulo. v.41. n.128. p.175-93. out./dez. 2.002.

PIMENTEL, Manoel Pedro. Legislação Penal Especial. São Paulo: Revista dos Tribunais, 1.972.

- Crimes Contra o Sistema Financeiro Nacional. São Paulo: Revista dos Tribunais, 1.987. . Direito Penal Econômico. São Paulo: Revista dos Tribunais, 1.973.

PINTO, Frederico de Lacerda da Costa. $O$ novo regime de crimes e contra-ordenações no código dos valores mobiliários. Coimbra: Almedina, 2.000.

PINTO JÚNIOR, Mario Engler. "O novo mercado da Bovespa e o compromisso da sociedade de economia mista com práticas de boa governança corporativa" in Revista da Procuradoria Geral do Estado de São Paulo. São Paulo. n.57/58. p.1326. jan./dez. 2.002.

PRADO, Luiz Regis. Bem jurídico-penal e constituição. 3. ed. rev. e atual. São Paulo: Ed. Revista dos Tribunais, 2.003 . Comentários ao Código Penal. $2^{\mathrm{a}}$. ed. São Paulo: Revista dos Tribunais, 2.003. . Direito Penal Econômico. São Paulo: Revista dos Tribunais, 2.004. . Direito Penal ambiental: problemas fundamentais. São Paulo: Ed. Revista dos Tribunais, 1.992.

PRIETO DEL PINO, Ana María. El Derecho Penal ante el uso de información privilegiada en el mercado de valores. Navarra: Editorial Arazandi, 2004.

PROENÇA, José Marcelo Martins. Insider trading - regime jurídico do uso de informações privilegiadas no mercado de capitais. São Paulo: Quartier Latin, 2.005.

QUEIROZ, José Eduardo Carneiro. "O Conceito de Valor Mobiliário e a competência da Comissão de Valores Mobiliários e do Banco Central do Brasil" in Aspectos atuais do Direito do Mercado Financeiro e de Capitais. Coord. Roberto Quiroga Mosquera. São Paulo: Dialética, 1.999, p. 131-135.

REALE JÚNIOR, Miguel. "Despenalização no direito penal econômico: uma terceira via entre o crime e a infração administrativa?" in Revista Brasileira de Ciências Criminais, São Paulo, Vol. 7, nº 28, p.116/129, out/dez 1.999.

. Teoria do Delito. $2^{\text {a }}$ ed. São Paulo: Revista dos Tribunais, 2.000. Instituições de Direito Penal. Vol. 1. Rio de Janeiro: Forense, 2.002. Instituições de Direito Penal. Vol. 2. Rio de Janeiro: Forense, 2.003. Direito Penal Aplicado. Vol. 4. São Paulo: Revista dos Tribunais, 1.994.

ROCCA, Carlos Antonio. "O papel do sistema financeiro privado na retomada do crescimento" in Revista da CVM. Rio de Janeiro. n.30. p.56-73. dez. 1.999. 
ROCHA, Jean Paul C. Veiga da. "As conseqüências institucionais do novo conceito de Valor Mobiliário: as competências do CMN, do Bacen e da CVM" in Aspectos atuais do Direito do Mercado Financeiro e de Capitais, $2^{\circ}$ volume. Coord. Roberto Quiroga Mosquera. São Paulo: Dialética, 2.000, p. 67-77.

ROXIN, Claus. Derecho Penal Parte General. Tomo I. $2^{\text {a }}$ ed. Madrid: Civitas, 2.003. . Problemas fundamentais de direito penal. Trad. Ana Paula dos Santos Luis Natscheradetz. Lisboa: Veja. 1.981. . “Es la protección de bienes jurídicos una finalidad del Derecho Penal?” trad. Iñigo Ortiz de Urbina Gimeno. in HEFENDEHL, Roland (ed.). La teoria del bien jurídico. Madrid: Marcial Pons, 2.007 .Estudos de Direito Penal; trad. Luís Greco. Rio de Janeiro: Renovar, 2.006.

RUIZ RODRÍGUEZ, Luis Ramón. Protección penal del mercado de valores. Valencia: Tirant Monografias, 1.997.

SCHÜNEMANN, Bernd. "Sobre la dogmática y la política criminal del derecho penal del medio ambiente" in Cuadernos de Doctrina y Jurisprudencia Penal. Buenos Aires, n. 2-9a, Set. 1.999, p. 627-653.

. Cuestiones básicas del derecho penal en los umbrales del tercer milenio. Lima: Idemsa, 2.006.

SERRANO MAÍlLO, Alfonso. "A utilização (distorcida) dos delitos de colarinho branco nos paradigmas anteempíricos" in Ciências Penais. ano 1, n. 1, jul-dez/2.004, p. 80112. São Paulo: Revista dos Tribunais, 2.004.

SHECAIRA, Sérgio Salomão. Criminologia. São Paulo: Revista dos Tribunais, 2.004.

SILVA, Ângelo Roberto Ilha da. Dos crimes de perigo abstrato em face da Constituição. São Paulo: Revista dos Tribunais, 2.003.

SILVA NETO, Manoel Jorge e. Direito Constitucional Econômico. São Paulo: LTr, 2.001.

SILVA SÁNCHEZ, Jesús-Maria. Eficiência e Direito Penal. Barueri: Manole, 2.004. . A expansão do direito penal. trad. Luiz Otavio de Oliveira Rocha. São Paulo: Revista dos Tribunais, 2.002. 2.002 . Aproximación al derecho penal contemporáneo. Barcelona: Bosch Editor,

SILVEIRA, Renato de Mello Jorge. Direito penal supra-individual. São Paulo: Revista dos Tribunais, 2.003.

Direito Penal Econômico como Direito Penal de perigo. São Paulo: Revista dos Tribunais, 2.006.

SILVEIRA, Renato de Mello Jorge e SALVADOR NETTO, Alamiro Velludo. "'SarbanesOxley Act' e os vícios do Direito Penal Globalizado” in Revista Ultima Ratio. Vol. 1. Rio de Janeiro, 2.006, p. 193-210. 
SILVEIRA FILHO, Sylvio Lourenço da. "Neoliberalismo, mídia e movimento da lei e da ordem: rumo ao estado de polícia" in Ciências Penais. ano 2, n. 2, jan-jun/2005, p. 253-268. São Paulo: Revista dos Tribunais, 2.005.

SIMONS, Beth A. The international politics of harmonization: the case of capital market regulation. International Organization. Cambridge. v.55. n.3. p.589-620. 2.001.

SIRIMARCO, Hélio. "Bolsa brasileira: globalizar ou ...?" in Revista da CVM. Rio de Janeiro. n.32. p.33-44. set. 2.000.

SOTO NAVARRO, Susana. La proteción penal de los bienes colectivos en la sociedad moderna. Granada: Comares, 2.003.

STERNBERG-LIEBEN, Detlev. "Bien jurídico, proporcionalidad y libertad del legislador penal” trad. Íñigo Ortiz de Urbina Gimeno. in HEFENDEHL, Roland (ed.). La teoria del bien jurídico. Madrid: Marcial Pons, 2.007.

TAVARES, Ana Lúcia Lyra. "O estudo das recepções de Direito" in Estudos jurídicos em homenagem ao Professor Haroldo Valladão. Rio de Janeiro: Livraria Freitas Bastos, 1.983 , p. $45-66$.

TIEDMANN, Klaus. Poder Econômico y Delito. Barcelona: Ariel, 1.985.

"Responsabilidad penal de personas jurídicas y empresas en derecho comparado" in. Revista Brasileira de Ciências Criminais, Vol. 3, $\mathrm{n}^{\circ}$ 11, p. 21-35, jul/set 1.995 .

TOLEDO, Francisco de Assis. Princípios básicos de Direito Penal. $5^{\mathrm{a}}$ ed. São Paulo: Saraiva, 2.000 .

VEIGA, Alexandre Brandão da. Crime de manipulação, defesa e criação de mercado. Coimbra: Almedina, 2.001.

VERGUEIRO, Carlos Eduardo. "As Bolsas de Valores como fenômeno comercial” in Revista da Faculdade de Direito da Universidade de São Paulo. São Paulo. v.98. p.209-20. 2.003.

. "A Lei Sarbanes-oxley e as inovações para a proteção do Mercado de Capitais” in Revista da Faculdade de Direito da Universidade de São Paulo. São Paulo. v.97. p.305-10. 2.002.

VIDIGAL, Álvaro Augusto. "O desenvolvimento do mercado de capitais brasileiro" in Revista da CVM. Rio de Janeiro. n.30. p.85-7. dez. 1.999.

WALD, Arnoldo. "A CVM e a evolução do mercado de capitais no Brasil" in Revista Forense. Rio de Janeiro. v.98. n.363. p.3-16. set./out. 2.002.

"O mercado de capitais no Brasil" in Revista de Direito Mercantil, Industrial, Econômico e Financeiro. São Paulo. v.27. n.71. p.47-9. jul./set. 1.988.

"O futuro do mercado de capitais" in Revista de Informação Legislativa. Brasília. v.25. n.100. p.287-90. out./dez. 1.988. "Novos rumos para a internacionalização do mercado de capitais" in Revista de Informação Legislativa. Brasília. v.26. n.102. p.77-82. abr./jun. 1.989. 
"Auto-regulação e mercado de opções" in Revista de Informação Legislativa. Brasília. v.27. n.108. p.189-92. out./dez. 1.990. . "Os instrumentos de modernização do mercado de capitais em 1991 e fortalecimento das empresas" in Revista de Direito Mercantil, Industrial, Econômico e Financeiro. São Paulo. v.30. n.82. p.5-12. abr./jun. 1.991.

YAZBEK, Otávio. Regulação do mercado financeiro e de capitais. Rio de Janeiro: Elsevier, 2.007.

ZAFFARONI, Eugenio Raúl e PIERANGELI, José Henrique. Manual de Direito Penal brasileiro: parte geral. $4^{\mathrm{a}}$ ed. rev. São Paulo: Revista dos Tribunais, 2.002.

ZUNZUNEGUI, Fernando. Derecho del Mercado Financiero. Madrid: Marcial Pons, Ediciones Jurídicas, 1.997. 


\section{RESUMO}

A necessidade de tutela eficiente do Mercado de Capitais é, atualmente, indiscutível. O advento de novas tecnologias e o tráfego internacional de capital cada vez maior; tornam o Mercado de Capitais, contemporaneamente, sujeito a amplos riscos e danos. Nesse contexto, o legislador tem respondido com a incriminação de condutas ofensivas ao mercado, contudo a formulação de tipos penais nem sempre se mostra adequada.

Dessa forma, questiona-se qual o bem juridicamente tutelado pelos crimes contra o Mercado de Capitais, referente material necessário à intervenção penal do Estado; bem como quais os critérios adequados para verificação da legitimidade de tal intervenção.

A dissertação está dividida em quatro capítulos.

No primeiro capítulo tem lugar a análise dos 'dilemas' do direito penal clássico frente aos novos riscos decorrentes da sociedade pós-moderna, com especial destaque à expansão dos Mercados de Capitais em uma sociedade globalizada; bem como os efeitos da chamada 'Globalização' no direito penal e o incremento do direito penal econômico.

O segundo capítulo destina-se a uma verificação das bases jurídicas e legais da regulação do Mercado de Capitais - fundamentais para uma melhor compreensão de sua tutela penal -, nomeadamente quanto ao seu controle no âmbito administrativo. Cumpre, ainda, no segundo capítulo, uma delimitação dos critérios científicos, externos ao bem jurídico, capazes de possibilitar um juízo de legitimidade da tutela penal do Mercado de Capitais.

O terceiro capítulo trata do processo de criminalização da tutela dos Mercados de Capitais, passando por uma análise crítica acerca da utilização simbólica do direito penal e de sua internacionalização desprovida de critérios dogmáticos; e se encerra com um panorama acerca do tratamento penal dado aos Mercados de Capitais nos Estados Unidos da América e Europa Continental. 
Por fim, o capítulo quarto versa acerca da tutela penal do Mercado de Capitais no Brasil. Nesse contexto, partindo-se da Teoria pessoal do bem jurídico desenvolvida por Hassemer, foram identificados os interesses patrimoniais do público investidor como referente material limitador da intervenção penal do Estado. Uma vez identificado o bem jurídico tutelado, é realizada uma análise dos tipos penais relativos às operações do Mercado de Capitais, notadamente, a manipulação de mercado e o uso indevido de informação privilegiada; bem como acerca da utilização de tipos penais excessivamente abertos e crimes de perigo abstrato. Nesse capítulo também é apresentada uma proposta de adequação típica aos crimes de manipulação de mercado e uso indevido de informação privilegiada.

Ao final, são expostas as conclusões do trabalho. 


\begin{abstract}
The need for efficient protection in the current Capital Market cannot be disregarded. The advent of new technologies and increasing international capital movements have rendered the contemporary Capital Market subject to extensive risks and damages. In this context, legislators have responded by criminalizing offensive conducts to the market, albeit through the establishment of criminal types that are not always adequate.

Therefore, this thesis questions which legal good is legally protected by crimes against the Capital Market, in relation to the necessary State criminal intervention, and which are the adequate criteria for the verification of the legitimacy of such intervention.
\end{abstract}

The thesis is divided into four chapters.

The first chapter refers to the assessment of the 'dilemmas' in classic criminal law in relation to the new risks arising out of post-modern society, especially regarding the expansion of the Capital Markets in a globalized society, in addition to the effects of the phenomenon referred to as 'Globalization' in criminal law, and in economic criminal law.

The second chapter focuses on the verification of the legal and judicial grounds for Capital Market regulation - essential for the better understanding of its criminal protection - specifically in relation to its control within the administrative scope. Furthermore, this chapter discusses the scientific criteria, external to the legal good, capable of providing for a legitimacy judgment of criminal protection of Capital Markets.

The third chapter refers to the criminalization process of protection in Capital Markets, including a critical assessment of the symbolic use of criminal law and its internationalization without any dogmatic criteria. The chapter ends with the panorama on the criminal treatment given to Capital Markets in the United States of America and Continental Europe. 
Finally, the fourth chapter assesses criminal protection of the Capital Market in Brazil. In this context, beginning with the theory of the legal good developed by Hassemer, the asset interests of the investing public were identified as limiting material reference for the State's criminal intervention. Once the protected legal good has been identified, an assessment on the criminal types in relation to the Capital Market is carried out, especially in reference to market manipulation and insider trading, as well as in regard to the use of excessively open criminal types and abstract danger crimes. This chapter also shows a proposal for the adequate typifying of market manipulation crimes and insider trading.

Conclusions on the subject are drawn at the end. 